\author{
UNIVERSIDADE DE SÃO PAULO - USP \\ ESCOLA DE COMUNICAÇÕES E ARTES - ECA \\ CAMPUS DE SÃO PAULO \\ PROGRAMA DE PÓS-GRADUAÇÃO EM MEIOS E PROCESSOS AUDIOVISUAIS
}

BERNARDO MARQUEZ ALVES

OS ESTUDOS DO SOM NO CINEMA:

Evolução Quantitativa, Tendências Temáticas e o Perfil da Pesquisa Brasileira Contemporânea sobre o Som Cinematográfico

São Paulo 
OS ESTUDOS DO SOM NO CINEMA:

\section{Evolução Quantitativa, Tendências Temáticas e o Perfil da Pesquisa Brasileira Contemporânea sobre o Som Cinematográfico}

Dissertação apresentada ao Programa de Pós-Graduação em Meios e Processos Audiovisuais para obtenção do Título de Mestre em Ciências. Linha de Pesquisa: Poéticas e Técnicas, Escola de Comunicações e Artes da Universidade de São Paulo.

Orientador: Prof. Dr. Eduardo Simões dos Santos Mendes. 


\section{(c) $(1 \otimes \Theta(\Theta)$}

A obra OS ESTUDOS DO SOM NO CINEMA: Evolução Quantitativa, Tendências Temáticas e o Perfil da Pesquisa Brasileira Contemporânea sobre o Som Cinematográfico de Bernardo Marquez Alves é licenciada com a Creative Commons Attribution-NonCommercial-NoDerivs 3.0 Unported License.

Permissões adicionais ao âmbito desta licença podem estar disponíveis em www.artesaosdosom.org.

\section{(a) comitiving}

\section{Attribution-NonCommerclal-NoDerivs 3.0 Unported (CC BY-NCND 3.0)}

\section{You are free:}

to Share - to copy, distribute and transmit the work

\section{Under the following conditions:}

Attribution - You must attribute the work in the manner specified by the author or licensor (but not in any way that suggests that they endorse you or your use of the work).

Noncommercial - You may not use this work for commercial purposes.

No Derivative Works - You may not alter, transform, or build upon this work.

\section{With the understanding that:}

\footnotetext{
Waiver - Any of the above conditions can be waived if you get permission from the copyright holder.

Public Domain - Where the work or any of its elements is in the public domain under applicable law, that status is in no way affected by the license.

Other Rights — In no way are any of the following rights affected by the license:

- Your fair dealing or fair use rights, or other applicable copyright exceptions and limitations;

- The author's moral rights;

- Rights other persons may have either in the work itself or in how the work is used, such as publicity or privacy rights.
} 


\section{AGRADECIMENTOS}

Agradeço em primeiro lugar aos meus pais pelo apoio incondicional e a todos meus familiares.

Ao meu orientador, Prof. Dr. Eduardo Santos Mendes, pela paciência e colaboração. E à CAPES que ajudou a financiar o projeto.

Aos amigos para toda hora Genésio (Genas), André Luiz (Harry), Thiago Franco, Angela Ribeiro, Damyler Cunha e Jefferson Pacaembu que me acolheram nos momentos essenciais.

Ao Fernando Henna, Daniel Turini, Gustavo Nascimento, Luiz Adelmo e à Tide Borges pelo apoio e oportunidades.

A todos os profissionais de som que nos últimos anos participaram da minha formação.

Aos pesquisadores que cederam e disponibilizaram seus trabalhos para a concretização dessa pesquisa. 
Toda a boa informação deveria estar condicionada, determinada mesmo, a gerar conhecimento, ou seja, ser de alguma forma utilizada, virar algo prático para as pessoas, em seus planos de estudo, em suas plataformas operativas, com efeitos indefinidos.

Nada mais injusto do que a informação escondida, encastelada no alto edificio da soberba ou guardada pela falsa modéstia do conhecimento tácito que some quando desfalece o seu transporte natural. 


\title{
RESUMO
}

ALVES, Bernardo Marquez. Os Estudos do Som no Cinema: evolução quantitativa, tendências temáticas e o perfil da pesquisa brasileira contemporânea sobre o som cinematográfico. Dissertação (Mestrado em Meios e Processos Audiovisuais). Escola de Comunicações e Artes, Universidade de São Paulo, 2013.

Esta dissertação pretende mapear e discutir o pensamento sonoro cinematográfico dos pesquisadores brasileiros contemporâneos através de uma revisão sistemática que aborda a evolução quantitativa, as tendências temáticas e o perfil da pesquisa brasileira contemporânea sobre o som no cinema. Os estudos selecionados para tal investigação e análise foram os livros, as teses, as dissertações e os artigos acadêmicos nacionais que contemplam o universo sonoro cinematográfico, publicados no Brasil no período entre os anos 2001 e 2011, e que articulam essencialmente questões que não são específicas da trilha musical.

Palavras-chave: Sound Studies; Estudos do Som no Cinema; Som; Cinema; Trilha Sonora; Audiovisual; Revisão Sistemática.

\begin{abstract}
ALVES, Bernardo Marquez. Film Sound Studies: quantitative developments, thematic tendencies and the profile of the film sound studies contemporary Brazilian research. Thesis (Master in Audiovisual Media and Processes). School of Arts and Communication, University of São Paulo, São Paulo, 2013.

This master thesis aims to map and discuss the film sound thinking of contemporary Brazilian researchers through a systematic review that approach the quantitative developments, the thematic tendencies and the profile of Brazilian contemporary Film Sound Studies. The studies selected for this research and analysis were national books, doctoral theses, master's theses and academic articles that address the universe of film sound, published in Brazil between 2001 and 2011, and essentially articulate issues that are not specific of the film score.
\end{abstract}

Key-words: Sound Studies; Film Sound Studies; Sound; Cinema; Soundtrack; Audiovisual; Systematic Review. 


\section{Lista de Tabelas}

TABELA I

Levantamento bibliográfico quantitativo realizado por ano (2001-2011).

TABELA II

Distribuição dos temas, subtemas, objetos e corpus específicos de estudo perante o formato, o título, o autor e o ano dos trabalhos.

TABELA III

Disposição de Grandes Áreas de conhecimento, Áreas e Programas de Pós-Graduação por Universidade

TABELA IV

Quantidade total de teses e dissertações por Área e Programa de Pós-Graduação

TABELA V

Quantidade total de livros, teses, dissertações e artigos publicados por autor..

\section{Lista de Gráficos}

\section{GRÁFICO I}

Levantamento bibliográfico quantitativo realizado por ano (2001-2011)

GRÁFICO II

Quantidade total de teses e dissertações por universidade.

GRÁFICO III

Porcentagem de teses e dissertações por universidade

GRÁFICO IV

Porcentagem de teses e dissertações por Área. 
INTRODUÇÃO.......................................................................................................10

1 METODOLOGIA...............................................................................................................26

2 A PESQUISA BRASILEIRA CONTEMPORÂNEA SOBRE O SOM CINEMATOGRÁFICO.................................................................................................... 35

2.1 Evolução Quantitativa................................................................................................. 36

2.2 Tendências Temáticas..................................................................................................48

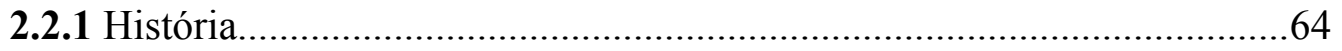

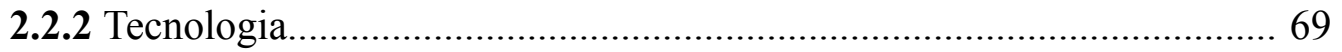

2.2.3 Percepção Sonora................................................................................

2.2.4 Processo de Criação...................................................................................... 75

2.2.5 Elementos da Trilha Sonora...................................................................

2.2.5.1 Estudos da Voz...................................................................... 80

2.2.5.2 Estudos do Ruído........................................................................ 83

2.2.5.3 Estudos do Silêncio...................................................................... 85

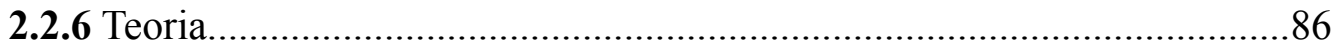

2.2.7 Estética e Estilo................................................................................. 87

2.2.8 Estudos de Caso.........................................................................................89

2.3 Perfil............................................................................................................................. 94

CONCLUSÃO

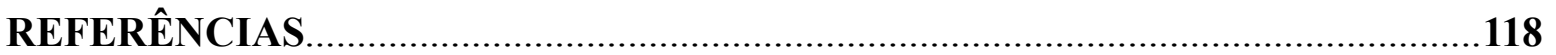




\section{ANEXOS}

ANEXO I: Lista bibliográfica completa distribuída por ano

ANEXO II: Lista bibliográfica completa distribuída por tendência temática

ANEXO III: Lista bibliográfica de teses e dissertações distribuídas por universidade..... 148

ANEXO IV: Lista bibliográfica de teses e dissertações distribuídas por Área e Programa de Pós-Graduação

ANEXO V: Lista bibliográfica de trabalhos que abordam questões relacionadas ao cinema brasileiro 155

ANEXO VI: Lista bibliográfica de artigos distribuídos por local de publicação. 158

ANEXO VII: Lista extra com materiais levantados mas que não se encaixaram no recorte da pesquisa 166 


\section{INTRODUÇÃO}

Estudos do som (Sound Studies) é o termo utilizado para designar o novo campo de pesquisa acadêmica que se consolida no final do século passado e que privilegia o som como objeto central de investigação. Inicialmente esteve sobretudo atrelado aos estudos de cinema (Film Studies). Como afirma HILMES (2005: 250), o estudo do som relacionado ao cinema seja talvez a maior e mais desenvolvida área que deve ser incluída em qualquer tentativa de delinear os Sound Studies. E é com essa vertente, a dos Film Sound Studies, que esta pesquisa trabalha. Isso porque os estudos do som vieram a se tornar um campo mais amplo, abrangendo estudos relacionados às ciências humanas e sociais, a aspectos da física, da tecnologia do áudio, da análise da cultura e das artes sonoras, assim como de outras mídias audiovisuais, etc.

Estudos do Som é uma área interdisciplinar emergente que estuda a produção material e o consumo da música, do som, do ruído e do silêncio, e como estes mudaram ao longo da história e em diferentes sociedades. Mas o faz através de uma perspectiva muito mais ampla que disciplinas padrões como etnomusicologia, história da música e sociologia da música. ${ }^{1}$ (PINCH; BIJSTERVELD, 2004: 636)

A proposta desta dissertação é mapear, discutir e analisar o status quo da pesquisa brasileira contemporânea sobre o som no cinema através de uma revisão sistemática que aborda a evolução quantitativa, as tendências temáticas e o perfil dos estudos do som cinematográfico no Brasil atualmente. Além disso, é objetivo realizar um levantamento bibliográfico e criar uma base de dados com livros, teses, dissertações e artigos acadêmicos sobre o assunto. Com a necessidade de restringir o objeto de estudo, serão priorizados aqueles materiais que articulam questões que não são específicas da trilha musical.

A opção por não investigar trabalhos que articulam questões exclusivas da trilha musical aparece uma vez que o campo de estudo sobre a música no cinema além de ser muito amplo, possui questões intrínsecas à linguagem musical que competem especialmente aos pesquisadores da área de música e aos músicos propriamente ditos.

Muitas são as publicações em língua estrangeira sobre o som no cinema, especialmente ocidentais advindas dos EUA e de países europeus como França e Inglaterra. Os documentos sobre o tema eram modestos até os anos 1970, mas se expandiram consideravelmente a partir dos anos 1980 e 1990. O desenvolvimento dos estudos do som no cinema pode ser observado em um breve panorama histórico de algumas de suas principais publicações.

Mesmo que o som já se manifestasse no período do cinema silencioso, é a partir de

1 Tradução do autor. 
1927, data convencionada como momento inaugural do cinema sonoro, que as primeiras escrituras atentas a este "novo" elemento começaram a surgir. No final da década de 1920 os textos que se concentravam principalmente em jornais e revistas de cinema, ficaram praticamente voltados a críticas e perspectivas relacionadas à chegada do som. Como grande destaque de crítica e reflexão de cunho mais estético e criativo, temos dois documentos europeus: a Declaração sobre o Futuro do Cinema Sonoro, redigida em conjunto pelos cineastas russos Sergei Eisenstein, V.I. Pudovkin e G.V. Alexandrov, em 1928; e o manifesto The Art of Sound, produzido pelo jornalista e realizador francês René Clair em 1929.

A Declaração sobre o Futuro do Cinema Sonoro que foi primeiramente publicada na revista Sovietski Ekran (Tela Soviética) de Moscou, e no jornal Zhinz Iskusstva (Arte Cinematográfica) de Leningrado em 1928, logo circulou o mundo despertando discussões. As idéias contrapontísticas dos cineastas russos que presavam por uma utilização do som nos filmes de forma diferenciada do então criticado padrão redundante do "cinema falado" norteamericano, foram reproduzidas, por exemplo, em 1930 na oitava edição da revista brasileira $O$ Fan, publicação do Chaplin Club, primeiro cineclube que manteve uma atividade sistemática no Brasil. Para os cineastas russos, o potencial audiovisual narrativo do cinema sonoro seria alcançado através do assincronismo entre sons e imagens. E complementando a declaração, em 1929 Pudovkin continuou a esmiuçar a busca pelos novos potenciais do cinema sonoro através do artigo Assincronismo como Princípio do Cinema Sonoro, mesmo com o lento desenvolvimento tecnológico na então URSS.

Nós que trabalhamos na URSS estamos conscientes de que, com nosso potencial técnico, não vamos caminhar em direção à realização prática do cinema sonoro em um futuro próximo. Ao mesmo tempo, consideramos oportuno afirmar uma série de premissas principais de natureza teórica, porque, por conta da invenção, parece que este avanço nos filmes parece que está sendo empregado de forma incorreta. Enquanto isso, um equívoco em relação às potencialidades desta nova descoberta técnica pode não apenas impedir o desenvolvimento e o aperfeiçoamento do cinema como arte, mas também ameaçar destruir todas suas atuais conquistas formais ${ }^{2}$. (EISENSTEIN; PUDOVKIN; ALEXANDROV, 1985: 83)

Mas existe uma grande diferença entre o desenvolvimento técnico do som e seu desenvolvimento como meio de expressão. As conquistas expressivas do som ainda estão muito atrás de suas possibilidades técnicas. [...] Nossa primeira questão é: Que novo conteúdo pode ser trazido para o cinema através do uso do som? Seria completamente falso considerar o som apenas como um dispositivo mecânico que nos permite aumentar a naturalidade da época. ${ }^{3}$ (PUDOVKIN, 1985: 86)

Já The Art of Sound é uma carta redigida em 1929 em Londres, cuja fonte de publicação

Tradução do autor.

Idem. 
original é desconhecida. A primeira versão impressa do documento se deu em forma de ensaio no livro Réflexion faite. Notes pour servir à l'histoire de l'art cinématographique de 1920 à 1951 do próprio René Clair, lançado em Paris em 1951 (WIERZBICKI, 2009: 256). Igualmente em oposição à prática hollywoodiana, o realizador francês faz a distinção entre o que então seria um "cinema falado", e o mais elaborado "cinema sonoro", sugerindo também novas possibilidades de utilização do som nos filmes.

O filme falado não é tudo. Há também o filme sonoro - no qual as últimas esperanças dos defensores do filme mudo estão colocadas. Eles contam com o filme sonoro para afastar o perigo representado pelo advento do cinema falado, esforçando-se para convencer-se de que os sons e ruídos que acompanham o filme podem constituir entretenimento suficiente para o público, impedindo-o de solicitar diálogo e podendo criar uma ilusão da "realidade" menos prejudicial para a arte do que o filme falado. ${ }^{4}$ (CLAIR, 1985: 92)

$\mathrm{Na}$ Europa, revistas inglesas dedicadas a arte cinematográfica publicavam da mesma maneira muitas críticas e reflexões relacionadas à chegada do som. A exemplo temos a revista Close-up, que existiu de 1927 a 1933, onde também foi publicado uma reprodução da Declaração sobre o Futuro do Cinema Sonoro em sua edição de outubro de 1928. "Houve um debate, e não apenas uma linha sobre som na Close Up"5 (DONALD; FRIEDBERG; MARCUS, 1998: 81).

Ainda na Inglaterra, outras revistas publicavam artigos sobre o som no cinema. A revista Cinema Quarterly era uma revista ligada ao movimento britânico de filme documentário e que defendia o uso expressivo do som no cinema. O jornal Film/Film Art era relacionado à atividade cinematográfica independente (SEXTON, 2004). Neste último inclusive, fora publicado mais um conhecido documento argumentando contra o excesso de voz nos filmes norte-americanos. O artigo intitulado Manifesto: dialogue on sound, lançado em 1934 e escrito pelo cineasta, historiador, crítico de cinema e professor Basil Wright em parceria com a crítica Vivian Braun, é na verdade a transcrição de um bate-papo entre ambos os autores. Ao refletirem sobre o potencial do som nos filmes, eles completam:

Wright: O que você quer dizer com o som em conexão com o filme?

V.B.: Antes de iniciar o seu filme você tem disponível cada som do mundo, do som das cotovias à voz de Mae West, da Sinfonia Júpiter aos motores de combustão interna.

W.: E a voz humana não é maior em valor do qualquer outro som. 6

(WRIGHT; BRAUN, 1985: 97)

\footnotetext{
Tradução do autor.

Idem.

Idem.
} 
No Brasil, vale citar duas revistas que se manifestaram em relação a esse polêmico período de transição no cinema e sobre a excessiva utilização dos diálogos nos filmes: $O$ Fan e Cinearte. A já citada revista $O$ Fan representava o pensamento dos cineclubistas do Chaplin Club, os quais compreendiam a chegada do som sincronizado como algo que vinha meramente atender a uma poderosa exigência comercial da indústria, um progresso técnico que representava um certo "retrocesso" do cinema a suas origens, onde os filmes eram dependentes de recursos cênicos e narrativos do teatro e da literatura (FELICE, 2011: 12). Dentre os textos publicados pelo $O$ Fan, está também em sua quarta edição de 1929 a transcrição da famosa entrevista Charles Chaplin attacks the talkies na qual Chaplin expressava sua aversão aos diálogos (COSTA, 2008: 77).

A Cinearte era uma revista mais atualizada em relação às novidades tecnológicas que surgiam no cinema. Matérias sobre o Vitaphone eram publicadas desde 1926, primeiro ano de existência da revista que mantinha correspondentes nos EUA. Além das discussões sobre o sonoro e o falado, e da seção "Som" sobre as novidades do cinema sonoro que esteve presente das edições de 1933 a 1940, encontra-se também na Cinearte textos sobre Acabaram-se os Otários, considerado o primeiro filme brasileiro sonoro, e das demais produções nacionais sonoras daquela época ${ }^{7}$.

Nos Estados Unidos, ao longo da década de 1930 é destaque o jornal da Society of Motion Picture Engineers (JSMPE). As publicações do JSMPE constituíam a mais completa bibliografia técnica da indústria cinematográfica da época. As discussões articuladas nos periódicos contavam com a participação de pesquisadores e profissionais renomados das principais companhias e estúdios cinematográficos dos Estados Unidos, constituindo importantes referências no meio. Os artigos analisavam as práticas, os fluxos e os métodos de trabalho nas produções cinematográficas, os parâmetros técnicos de gravação e reprodução do som nas salas de exibição, questões artísticas e científicas envolvendo a prática e a recepção dos filmes sonoros, abordagens relacionadas a aspectos históricos do som no cinema como o desenvolvimento dos equipamentos de gravação de som sincrônico, dentre outros assuntos que muito influenciaram nas diretrizes de elaboração do código de representação estabelecido pelo cinema clássico norte-americano. Foi neste jornal principalmente, por exemplo, onde o embate relacionado a adequação das escalas entre a representação visual e a representação sonora nos filmes, envolvendo questões de inteligibilidade e a fidelidade acústica - ou o "naturalismo" do som - foi discutido ${ }^{8}$. Em cada edição do JSMPE havia ainda um espaço

Para mais detalhes sobre as discussões nas revistas $O$ Fan e Cinearte, ver os tópicos "O fã do cinema mudo e a ojeriza ao falado" e "Em Cinearte" de "O Som no Cinema Brasileiro" (COSTA, 2008: 75-104).

8 Alguns textos que compunham esse embate envolvendo a incorporação do som no sistema de representação 
reservado para resenhas de livros e resumos de artigos publicados em outras revistas, o que também faz desse jornal uma importante base documental da produção literária da época ${ }^{9}$.

No final da década de 1930, outro documento a ser mencionado é o artigo escrito pelo brasileiro Alberto Cavalcanti e publicado na revista nova-iorquina Films: a quarterly of discussion and analysis, e na revista londrina Film, em 1939. O artigo Sound in Films começa já desmistificando a existência do cinema intitulado silencioso, demonstrando indícios da existência do som nesse período:

A historia do som no cinema não teve inicio, como vários historiadores têm presumido, com a introdução do filme sonoro, mas com a própria invenção do cinema. Em nenhum período da historia do cinema foi habitual que ele fosse exibido publicamente sem algum tipo de acompanhamento sonoro. Em outras palavras, o cinema silencioso nunca existiu. (CAVALCANTI, 1985: 98)

Cavalcanti salienta então que, a principio, a grande diferença da chegada do cinema sonoro seria que a partir daquele momento os elementos sonoros (fala, música e ruído) poderiam ser organizados adequadamente dentro da construção do filme em si, de modo que as criações sonoras do diretor estariam ligadas de forma permanente à obra. Mas critica a forma como de fato o som seguiu sendo trabalhado, reforçando que a predominância dos diálogos nos filmes resultava na opressão de outros elementos de interesse visual, do ruído e da música. $\mathrm{O}$ autor, que também acreditava no assincronismo como maneira mais sugestiva de utilização do som nos filmes, continua o texto analisando os potenciais de cada elemento sonoro e ainda discute o silêncio como um componente dramático.

Alberto Cavalcanti foi um importante realizador e pesquisador cinematográfico, trabalhou no cinema comercial e de vanguarda francesa da década de 1920, em documentários britânicos da década de 1930 fazendo parte da G.P.O. Film Unit ${ }^{10}$, no Brasil foi chefe de produção e um dos fundadores da Companhia Cinematográfica Vera Cruz. Artista cosmopolita, influenciou outros diretores e foi grande responsável pelas inovações e experimentações cinematográficas de seu tempo. Em 1937 que Cavalcanti escrevera também o texto "O Som", publicado pela primeira vez apenas em 1953 na primeira edição de seu livro "Filme e Realidade". Esse texto também questiona o uso dos elementos da trilha sonora nos filmes, criticando a forma como o som era tratado na produção cinematográfica da época.

do cinema clássico também apareceram na revista American Cinematographer e em alguns livros da época como, por exemplo, Recording Sound for Motion Pictures de McGraw-Hill do ano de 1931. Mais sobre o assunto, ler o capítulo Sound Space em ALTMAN (1992: 46-64).

9 Muitos dos volumes anuais, com edições mensais, do JSMPE estão digitalizados e disponibilizados para consulta gratuitamente no endereço eletrônico: <http://archive.org/search.php?query=Journal\%20of\%20the \%20Society\%20of\%20Motion\%20Picture>. Acesso em 20 de jul. 2011.

10 General Post Office Film Unit, organização estatal criada para produzir filmes de propaganda para os serviços públicos da Inglaterra e de grande importância na história do documentário. 
Apesar do grande bloco de produção teórica dos estudos do som no cinema estar concentrado ou no período de início do cinema sonoro, ou a partir dos anos 1980, entre os anos 1940 e os anos 1970 também houve documentos significativos para a pesquisa do som cinematográfico que merecem ser resgatados.

Foi na década de 1940 que o cinema começou a ser analisado de fato como uma arte audiovisual. No berço das abordagens mais aprofundadas sobre a relação entre som e imagem no universo cinematográfico se destacam os trabalhos do compositor e pesquisador francês Pierre Schaeffer. O conceituado Essai sur la radio et le cinéma: esthétique et technique des arts-relais, por exemplo, teve seus textos originalmente escritos nos anos de 1941 e $1942^{11}$. O cinema e a arte radiofônica foram aí então eleitos como os precursores da era audiovisual. É em 1946 que Schaeffer publica na revista Revue du Cinéma outro ensaio com foco maior no estudo dos componentes sonoros dos filmes. Intitulado L'élement non visuel au cinéma, o texto foi dividido em três partes: Analyse de la bande 'son', Conception de la musique e Psychologie du rapport vision-audition.

O último ensaio, em particular, retorna e desenvolve uma visão construtivista do documento audiovisual, segundo a qual, independentemente do assunto que está sendo narrado, a mensagem estética é transmitida integralmente pela organização formal dos objetos, imagens visuais e modulações sonoras. A partir da divisão habitual da pista de áudio em ruído, voz e música, Schaeffer demonstra como todo o processo acústico pode realmente estar ligado à primeira categoria, uma vez que verbalização não é nada mais que o ruído produzido pelos humanos: "[...] pode-se assim, afirmar que o texto tem muito menos importância do que a entonação das frases, a qualidade das vozes individuais e o grau de inteligibilidade [...] Desta forma, também deixa a ação explícita, mas não menos ou mais do que a própria realidade, que é muitas vezes elíptica e ambígua" (Schaeffer, 1946b: 47) ${ }^{12}$. Assim, esses ruídos verbais e de ambiente, pertencem a um único domínio de composição audiovisual, constituindo um contraste perfeito para a imagem na medida em que este último não faz nada mais que mostrar coisas. Além disso, sendo o resultado de um movimento físico, tais eventos sonoros atestam a presença de uma ação, de uma mudança, e consequentemente, contribui para a dinâmica da cena como um todo. ${ }^{13}$ (BIZARRO, 2011: 6-7)

Schaeffer funda em 1951 o Groupe de Recherches Musicales (GRM), grupo de pesquisa francês que estuda o som e a música concreta. Seus pensamentos vieram posteriormente a influenciar, a partir da década de 1980, o trabalho de um dos principais pesquisadores contemporâneo do som cinematográfico, seu aluno Michel Chion.

${ }_{11}$ Esse trabalho foi reconstituído e publicado posteriormente em formato de livro no ano de 2010, com a colaboração de Jacqueline Schaeffer, viúva e herdeira de Schaeffer que realizou transcrições de excertos do diário de seu falecido marido. Foi também publicado no Brasil no mesmo ano pela Editora UFMG. SCHAEFFER, Pierre. Essai sur la radio et le cinéma. Esthétique et technique des arts-relais 1941-1942. Carlos Palombini - Sophie Brunet [dir.], Paris: Allia, 2010.

12 SCHAEFFER, Pierre. L'élément non visuel au cinéma (1), Analyse de la bande son. Revue du cinéma, 1, 1946b, pp. 45-48.

13 Tradução do autor. 
Voltando para a década de 1940, um livro lançado em 1947 em Londres pode ser considerado o primeiro a abordar o som especificamente no cinema documental. Sound and the Documentary ${ }^{14}$, do engenheiro de som Ken Cameron. Segundo MANCHEL (1990: 86), o livro propõe uma clara e fascinante abordagem dos processos de edição de som e mixagem no documentário.

Nos EUA, o Journal of Society of Motion Picture Engineers continuou publicando muitos textos sobre o som cinematográfico. Em especial, no volume 48, também do ano de 1947, o artigo Historical Development of Sound Films de E. I. Sponable que foi divulgado em duas partes: a primeira presente na edição do mês de abril e a segunda na de maio. Este documento foi para a época a mais completa revisão histórica do desenvolvimento do som nos filmes. Através de um preciso levantamento cronológico até o ano de 1930, o texto é dividido em sete tópicos: primeiros passos na história da gravação de som; o trabalho de Theodore Case e Lee DeForest; a comercialização do Movietone pela FOX; o progresso dos filmes sonoros no exterior e a relação com a FOX; o trabalho de som de acordo com os sistemas da Western Electric; o trabalho de som no âmbito do sistema da RCA; e diversos sistemas de som (SPONABLE, 1947). Este artigo foi ainda complementado no volume 64 do JSMPTE pelas três partes do texto History of Sound Motion Pictures que discutiu outros importantes avanços do som no cinema a partir do ano de 1930, disponibilizando também uma ampla bibliografia sobre aspectos da tecnologia do som (KELLOGG, 1955).

Vale ressaltar que no início da década de 1950, além da criação do GRM já citada, houve o surgimento da revista Cahiers du Cinéma igualmente em 1951 na França. Esta última é desde então uma das mais importantes e influentes revistas de crítica de cinema do mundo. Nela, Pierre Schaeffer publica em 1954 Les nouvelles techniques sonores et le cinema ${ }^{15}$. Desta vez desbravando novas técnicas sonoras associadas ao cinema a partir também da música concreta. Um ano antes, era publicado no jornal The Quaterly of Film Radio and Television da Universidade da Califórnia, um texto do importante cineasta animador escocês Norman McLaren. Em Notes on Animated Sound, McLaren (1953) descreve passo a passo seus métodos e técnicas de trabalho com a animação sonora na película. Trabalho este de vanguarda para a estética do som no cinema de animação.

A década de 1960, não possui muitos documentos publicados. Porém, duas revistas francesas merecem destaque por dedicarem edições especiais ao som cinematográfico. A primeira é a revista Cahiers du Cinéma e sua edição de número 152 de fevereiro de 1964,

14 CAMERON, Ken. Sound and the Documentary. London: I. Pitman, 1947.

15 SCHAEFFER, Pierre. Les nouvelles techniques sonores et le cinema. Cahiers du Cinéma, n. 34. Paris, 1954. 
onde apresenta um tópico especial intitulado La Bande-Son. Inicialmente os documentos que participam desse tópico se relacionam mais com aspectos musicais, como a entrevista com o maestro compositor Pierre Boulez e o artigo "De Wozzeck à Vertigo" de T.M.F Steen, que relaciona a partitura de Alban Berg para Wozzeck com a trilha musical de Bernard Herrmann para o filme de Hitchcock "Um Corpo que Cai" (1958). Mas o destaque vai para o texto "Vers une dialectique du film sonore" de Michel Fano, que elucida a relação entre música, ruído e a fonética das palavras na composição da trilha sonora cinematográfica, buscando expandir a importância da convergência entre esses elementos nos filmes, e afirma: "A música é elemento arquitetônico da banda sonora assim como os ruídos ou o aspecto fonético das palavras"16 (FANO, 1964: 30); e o artigo Eloge de la Phonie de Jean Baronnet que foca em aspectos das qualidades do som e da escuta, e logo questiona: “... é permitido perguntar por quê, se existe um diretor de fotografia, não há um diretor de som cujo papel é coordenar tudo o que é usado na mixagem, incluindo a música, e de dar um tom particular para estas pistas sonoras" ${ }^{\prime 17}$ (BARONNET, 1964: 37).

A segunda é a revista La Revue du Cinéma, relacionada à associação UFOLEIS (Union française des ouvres lä̈ques d'éducation par l'image et le son), que lança no exemplar de número 215 de março de 1968 sua edição especial sobre o som cinematográfico. Os artigos publicados foram: Le Cinéma est sonore de Françoise Chevassu, que versa sobre a relação imagem e som no cinema a partir de questões da percepção física, de estéticas de montagem, e dedicando um bom espaço para discutir possíveis funções da música, dos diálogos e dos ruídos. Les mots et les lettres de Raymond Lefèvre, debatendo sobre a questão da dublagem e da legendagem nos filmes. E Quand le son était muet de Guy Gauthier, discursando sobre como os cineastas do período do cinema silencioso lidavam com a ausência da voz, da palavra, em seus filmes. A revista ainda foi complementada com dois dossiês: Les rapports $d u$ texte et de l'image, organizado por Guy Gauthier, reunindo citações retiradas de textos de críticos e cineastas que discutiram a relação da palavra com o cinema. E Quatre cinéastes parlent de la bande son, organizado por René Tabès, também contendo citações de declarações dadas pelos cineastas Sergei Eisenstein, Josef von Sternberg, Fritz Lang e Jean Renoir a respeito do som no cinema. Além disso, foram publicadas entrevistas com doze diretores, todos abordando questões sonoras cinematográficas. Entre os entrevistados estão Robert Bresson e Jean-Luc Godard (CHEVASSU, 1968).

Estas duas edições citadas demonstram uma maior dedicação das revistas francesas de

16 Tradução do autor.

17 Idem. 
cinema em refletir sobre a trilha sonora, o que gera indícios do crescimento do interesse sobre o som cinematográfico como objeto de estudo na França.

$\mathrm{Na}$ década de 1970 vale destacar especialmente a defesa da tese de pós-doutorado do historiador norte-americano Douglas Gomery, intitulada The Coming of Sound to the American Cinema: a history of the transformation of an industry (1975), base para uma série de outros artigos e um livro ${ }^{18}$ publicados posteriormente. O trabalho de Gomery, que contempla aspectos da história do som cinematográfico, se diferencia de outros estudos históricos tradicionais por não ignorar fatos relacionados às complexas questões da economia e da demanda ideológica que desempenham um papel na formação da evolução do cinema, como explicam WEIS e BELTON:

\begin{abstract}
Histórias tradicionais sobre a chegada do som focam em um conjunto de "grandes homens" - a maioria inventores ou cineastas - que sozinhos conduziram a transição para o cinema sonoro. Um curso linear dos acontecimentos, vistos como uma evolução natural em direção a um objetivo pré-determinado, leva inevitavelmente ao The Jazz Singer. Infelizmente, essas histórias tendem a ignorar as complexas pressões da economia e da demanda ideológica que desempenham um papel na formação da evolução do cinema. [...] Baseando-se na teoria econômica neoclássica, Gomery situa as mudanças técnicas dentro de um contexto econômico mais amplo. [...] Gomery defende uma história do som que é determinada economicamente, inspirada pelo desejo de controle de patentes e aumento dos lucros. ${ }^{19}$ (WEIS; BELTON, 1985: 3)
\end{abstract}

É também nessa década que surgem os primeiros artigos de outros pesquisadores vindos de escolas de cinema, como David Bordwell, Kristin Thompson, Daniel Percheron e Claudia Gorbman que apresentaram novas formas de análises audiovisuais. Esta última em particular, foi quem propôs pela primeira vez a categoria narrativa denominada "meta-diegética", em seu artigo Teaching the Soundtrack (1976).

No meu conhecimento, o primeiro que propôs a categoria meta-diegética referindo-se a sons internos foi Claudia Gorbman em sua taxionomia de sons para filme. De acordo com Gorbman, a fonte sonora no nível narrativo pode ser diegética, extra-diegética e meta-diegética. Som meta-diegético foi explicado como um som imaginado, ou talvez, alucinado por um personagem..$^{20}$ (MILICEVIC, s.d.)

Um marco na consolidação dos estudos do som no cinema em âmbito internacional foi o lançamento da edição de número 60 da revista Yale French Studies. Publicada pela Yale University Press em 1980, foi editada por Rick Altman e intitulada Cinema/Sound. Além de sugerir novos rumos e possibilidades para uma abordagem mais integrada à experiência cinematográfica, teve o objetivo de romper com a idéia de um cinema observado apenas como uma arte essencialmente visual. ALTMAN (1980b) pontua que aspectos da inovação

18 GOMERY, Douglas. The Coming of Sound: a history. New York: Routledge, 2005.

19 Tradução do autor.

20 Idem. 
tecnológica, econômica e artística de certa forma sempre estiveram presentes em livros e análises que discorriam sobre o cinema. Ele cita como exemplo as investigações presentes no JSMPE sobre o desenvolvimento dos sistemas de gravação e reprodução do som e sua sincronia com a imagem nas experimentações audiovisuais de Thomas Edson, Lee de Forest, Theodore Case e Earl Sponable; ou mesmo os manifestos e reflexões sobre o papel da trilha sonora propostas por realizadores como René Clair, Sergei Eisenstein, Pudovkin, Alexandrov, Béla Balázs, Charlie Chaplin e críticos como Rudolf Arnheim e Siegfried Kracauer. Esses estudos espelhavam-se no período de chegada e consolidação do som no cinema, mas não havia uma considerável integração na linguagem de análise do som cinematográfico. A teoria e a crítica de cinema permaneciam prioritariamente limitadas a aspectos da imagem. Para Altman, o crescimento de uma sensibilidade relativa aos problemas referentes à tecnologia do som foi o provável e mais importante requisito responsável pelo renascimento do interesse no estudo da trilha sonora. Os artigos publicados na revista foram divididos em quatro áreas. São elas: teoria, história, música e estudos de caso. Dentre os pesquisadores que participaram desta edição estavam Claudia Gorbman, Daniel Percheron, Mary Ann Doane, Kristin Thompson e David Bordwell.

Outro mérito presente na Cinema/Sound e proporcionado por Claudia Gorbman, foi a publicação de um extenso levantamento bibliográfico onde reuniu-se praticamente todos os livros, ensaios e entrevistas relacionadas à trilha sonora cinematográfica publicados nos EUA e na Europa até aquela data. A intitulada Bibliography on Sound in Film (GORBMAN, 1980) possibilitou o acesso a uma informação até então dispersa no campo dos estudos de cinema.

Enquanto isso no Brasil, destacaram-se os textos, entrevistas e depoimentos reunidos por Jean-Claude Bernardet na edição de número 37 da revista Filme Cultura de 1981, intitulada "Som e Cinema". Esta pode ser considerada uma das primeiras publicações do país, se não a primeira centrada especificamente na discussão da trilha sonora cinematográfica nacional.

Bernardet, além de fazer uma breve introdução, ordena uma série de depoimentos e entrevistas, formando uma espécie de dossiê. Dão sua contribuição os precursores Luís de Barros e Humberto Mauro, Watson Macedo; Arthur Omar, Vladimir Carvalho e Geraldo Sarno, expondo suas diferentes concepções sonoras para o documentário; Leon Hirszman. Ainda compositores como John Neschling, Remo Usai, Caetano Veloso, por conta principalmente do bom trabalho em São Bernardo, de Leon Hirszman, Paulo Moura. E, por fim, técnicos, como Vitor Rapozeiro e Juarez Dagoberto. (COSTA, 2008: 9)

Depois da edição de número 60 da revista Yale French Studies, a primeira grande coletânea sobre o som no cinema publicada no formato de livro foi "Film Sound: theory and 
practice" (WEIS; BELTON, 1985a), que reúne artigos da área com relevante importância histórica, artigos recentes mas que apareceram em fontes efêmeras, e também outros materiais para complementar as lacunas de estudo sobre a estética do som e o próprio desenvolvimento da história do cinema sonoro, indo além do período de transição do silencioso para o falado. WEIS e BELTON (1985b) reafirmam a premissa de que até a década de 1980, as publicações sobre o som em filmes na maioria dos casos tinham sempre como foco apenas dois temas centrais: a música do filme e o nascimento do cinema sonoro. E ainda, esses materiais muitas vezes ou não tinham sido traduzidos, ou estavam fora de catálogo, ou pertenciam a revistas que não estavam disponíveis. Esta coletânea conta novamente com a publicação de um levantamento bibliográfico de Claudia Gorbman, desta vez como uma bibliografia comentada.

Nesta década Michel Chion, um dos mais importantes pesquisadores contemporâneos da área, começa a publicar seus primeiros textos. Discípulo direto do conceituado pesquisador e compositor francês Pierre Schaeffer, Chion é autor de vários livros representativos da área, como por exemplo: La Voix Au Cinéma (1982), Le Son au Cinéma (1985) e L'Audio-Vision: son et image au cinéma (1991). Este último é na verdade uma compilação, revisão e ampliação dos conceitos e teorias distribuídas nas publicações anteriores do autor. Para se ter uma breve noção da importância desse trabalho, o livro também ganha versões traduzidas em espanhol em 1993, em inglês em 1994 (traduzido por Claudia Gorbman), em italiano em 1997 e em português (de Portugal) em 2011. De fato, os conceitos propostos por Chion em suas obras provocaram uma evolução no pensamento sobre o som e o audiovisual na teoria do cinema, expandindo os estudos na área. Dentre alguns conceitos famosos está o de "valor agregado", de "contrato audiovisual", de "audiovisão", de "som acusmático", de "vocossentrismo", o desenvolvimento de ideias acerca da escuta fílmica, dentre outros.

O compositor, cineasta e teórico francês Michel Chion dedicou grande parte de seu livro Audio-Vision no sentido de delinear os vários aspectos do fenômeno do som no filme - que ele nomeia de "valor agregado" -, e esta alquimia também está presente no âmago de seus três trabalhos antecedentes, ainda não traduzidos para o inglês: $L a$ Voix Au Cinéma, Le Son au Cinéma e La Toile Trouée. [...] O primeiro passo essencial que Chion dá é assumir que não existe nenhuma "harmonia pré-existente e natural entre imagem e som". [...] O desafio para um teórico como Chion, por outro lado, é como definir - de forma tão ampla, mas a mais precisa possível - as circunstâncias sob quais essa "relação" pode ser feita, foi feita no passado, e poderá ser melhor realizada no futuro. Este desafio Chion empreende nos primeiros seis capítulos do Audio-Vision na forma de um "contrato audiovisual" - uma síntese e extensão das teorias desenvolvidas nos últimos dez anos em seus primeiros três livros. [...] Além disso, outras idéias de Chion são, para mim, ideias completamente novas e originais de se pensar sobre o assunto [...]. Mas a verdadeira conquista do Audio-Vision é - além de simplesmente nomear e descrever estes conceitos e idéias isoladamente propiciar uma síntese em um todo coerente, cujo padrão torna-o acessível 
tanto ao não-profissional como aos que já possuem experiência no ofício. ${ }^{21}$ (MURCH, 1994)

Os anos 1990 chegam para efetivar a presença dos estudos do som como campo de pesquisa acadêmica, ao menos a nível do exterior. Além do lançamento do já mencionado livro de Michel Chion, L'Audio-Vision (1991), outras quatro coletâneas ganham destaque: Sound Theory / Sound Practice (ALTMAN, 1992) com uma diversidade de artigos compilados tratando o cinema como "evento" e propondo diferentes modelos de se pensar o cinema em geral e a trilha sonora em especial. É neste trabalho, por exemplo, que Altman expõe suas críticas em relação à forma como as teorias do cinema vieram lidando com o som ao longo dos anos, através do que ele denomina de "quatro falácias e meia do cinema" 22 . Sound for Picture: an inside look at audio production for film and television (FORLENZA; STONE, 1993) que reúne basicamente artigos publicados na revista $\mathrm{Mix}^{23}$ sobre estudos de caso do som em filmes específicos e textos sobre a complexa arte do sound design no cinema; Sound-on-Film: interviews with the creators of film sound (LoBRUTTO, 1994) contendo vinte e sete entrevistas com renomados profissionais do meio, de técnicos de som direto a editores de som, artistas de foley e mixadores, por exemplo, e, consequentemente, disponibilizando informações sobre a prática de produção sonora e suas particularidades até antes não registradas; e Sounds of Movies: interviews with the creators of feature sound tracks (PASQUARIELLO, 1996) com vinte entrevistas também divididas entre profissionais de todas as etapas da produção sonora cinematográfica.

A conexão entre o universo teórico e a descrição prática do processo de trabalho, produção e criação sonora no cinema, proporcionada de certa forma já nesses livros de entrevistas, e que acaba por também gerar materiais didáticos importantes para o desenvolvimento do campo profissional da área, começa a ser mais recorrente. Exemplos disso estão na publicação da primeira edição do livro The Practical Art of Motion Picture Sound (YEWDALL, 1999), contendo exemplos práticos, dados técnicos e dicas de criação sonora cinematográfica. E em dois artigos famosos de dois grandes sound designers que sempre demonstraram interesse em interagir com o campo acadêmico. O primeiro é o intitulado Sound Design: the dancing shadow de Walter Murch, publicado em 1995 na coletânea Projections 4: Film-makers on Film-making, mas que posteriormente ficou mais

\footnotetext{
21 Tradução do autor.

22 ALTMAN, Rick. Introduction: four and a half film falacies. In: Sound Theory / Sound Practice. New York: Routledge, p. 35-45, 1992.

23 Uma das principais revistas internacionais sobre áudio profissional e produção musical. Disponível em: $<$ http://mixonline.com/>.
} 
conhecido por sua versão adaptada intitulada Stretching Sound to Help the Mind See (MURCH, 2000), que é uma combinação de princípios gerais, explicações técnicas e contextos teóricos desenvolvidos ou praticados por Murch. E o segundo é o artigo Design a Movie for Sound de Randy Thom, publicado no número 27 da revista Iris de 1999, onde o autor afirma que a melhor maneira de um cineasta tirar proveito do som é pensando-o desde o roteiro, na pré-produção.

Inclusive, esta mesma revista Iris, de número 27, editada por Rick Altman e intitulada The State of Sound Studies/Le son au cinéma, état de la rechearche, pode ser considerada a primeira que publicou uma edição completa dedicada exclusivamente a avaliar o estado da pesquisa sobre som no cinema no exterior. Nela, Rick Altman confirma a consolidação do denominado "Sound Studies" como um novo campo acadêmico reconhecido e respeitado pelas universidades, pelas editoras e até mesmo pelos meios de comunicação. Inclusive, a maturidade atingida fez com que os estudos do som ultrapassassem a especificidade do cinema e se tornassem aptos para abordagens interdisciplinares.

Sound Studies: um domínio em plena expansão.

Eles dizem que é preciso várias gerações para garantir a sobrevivência de uma nova espécie. O mesmo é válido para cada novo campo acadêmico. Com essa edição nós entramos na quarta geração dos Sound Studies. Aproximadamente a vinte anos atrás, tudo começou com a edição da Yale French Studies intitulada Cinema/Sound, que rapidamente saiu de catálogo e foi substituída pelo Film Sound: theory and practice, e depois pelo Sound Theory/Sound Practice. [...] Mais do que nunca, o estudo do som é agora reconhecido pelas mesmas instituições (universidades, meios de comunicação, editoras) que só recentemente saíram do caminho de impedir este novo domínio. ${ }^{24}$ (ALTMAN, 1999b: 3)

Além do texto de Randy Thom, a revista conta com um artigo de Michel Chion, tratando dos problemas e soluções para desenvolver o estudo do som na Europa e no mundo; com uma bibliografia comentada das literaturas sobre sound design recentes à época realizada por Elisabeth Weis; um artigo de Jay Beck e Franck Le Gac sobre fontes de conteúdo encontradas na internet destinadas ao estudo do som no cinema; um texto com notas e revisões dos principais colóquios e conferências sobre os estudos do som cinematográfico realizados ao longo da década de 1990; dentre outros.

Os anos 1990, portanto, também marcaram o início da frutífera e multifacetada troca de conhecimentos teóricos e práticos na área através da internet, a qual progride até os dias de hoje. O maior exemplo disso é o website Film Sound (www.filmsound.org), idealizado pelo professor sueco Sven E. Carlsson em 1997, e que aglomera, por exemplo, um vasto glossário com definições de termos da área, uma bibliografia de livros e jornais sobre o som no cinema,

24 Tradução do autor. 
entrevistas e artigos que tratam desde estudos da trilha sonora de filmes específicos a questões mais técnicas e teóricas, além de também ser precursor de um grupo de discussão por email denominado Sound-Article-List e que reúne pesquisadores e profissionais renomados do mundo inteiro para promover e incentivar a arte criativa do trabalho com o som no cinema.

Voltando ao universo brasileiro, é também na década de 1990 que começam a surgir os primeiros trabalhos acadêmicos sobre o som no cinema. Dentre as primeiras pesquisas realizadas no país está a dissertação de David Pennington defendida na UNB em 1993 com o nome de "Som Direto", propondo resgatar alguns aspectos do conhecimento da atividade de trabalho com o som direto dentro do audiovisual; a dissertação de Ney Carrasco "Trilha Musical: música e articulação fílmica”, defendida na Escola de Comunicação e Artes da USP no mesmo ano de 1993, abordando a trilha musical como recurso de articulação da narrativa fílmica e demonstrando o modo pelo qual a música se insere na dramaturgia do cinema; a dissertação de Eduardo Santos Mendes, intitulada "A trilha sonora nos curtas-metragens de ficção realizados em São Paulo entre 1982 e 1992”, defendida na ECA/USP em 1994, e que além de estudar a função da narrativa sonora dentro dos curtas-metragens paulistanos do período estipulado, faz um breve levantamento histórico do desenvolvimento do som no cinema e expõe alguns modelos de análise da trilha sonora cinematográfica; a dissertação "Espaço fílmico sonoro em Arthur Omar" de Guiomar Ramos defendida também na ECA/USP em 1995, e que investiga o uso e o potencial do som na obra do cineasta Arthur Omar. Ainda temos nessa década a dissertação de Luiz Cláudio Cajaiba Soares denominada "Versão Brasileira: dublagem na tv como recurso difusor do cinema", defendida na UFBA em 1997, e que estuda sob óticas estéticas e artísticas o fenômeno da dublagem em filmes produzidos para cinema, tratando especialmente das versões distribuídas para as emissoras de TV; a dissertação de Suzana Reck Miranda nomeada "A Música no Cinema e a Música do Cinema de Krzysztof Kieslowski”, defendida em 1998 na UNICAMP, e que descreve características específicas da utilização da música do compositor polonês Zbigniew Preisner em dois filmes de Krzysztof Kieslowski: A Dupla Vida de Véronique (1991) e A Liberdade é Azul (1993). Há também a dissertação de Luiz Adelmo Manzano intitulada "A Relação SomImagem no Cinema: a experiência alemã de Fritz Lang”, defendida na USP em 1999, discorrendo sobre o papel do som no cinema e aplicando os conceitos estudados em duas obras do diretor alemão Fritz Lang: Metropolis (1925-1926) e M, o Vampiro de Düsseldorf (1931). A dissertação de Luciana Almeida Pereira com o título "Princípios da Articulação Sonora no Cinema", defendida em 1999 na UFMG, e que analisa o desenvolvimento da linguagem sonora e as teorias que ampararam as etapas de evolução das tecnologias do som 
ao longo da história do cinema. E a tese de doutorado de Ney Carrasco denominada "Sygkhronos: a formação da poética musical do cinema", defendida também na USP em 1999, mostrando além do processo de formação poética, a evolução do papel da música no cinema. Fechando o século XX, há ainda a tese de Eduardo Santos Mendes, "Walter Murch: a revolução no pensamento sonoro cinematográfico", defendida na USP em 2000, e que discorre sobre a importância de Murch na mudança do pensamento sonoro dos filmes norteamericanos de ficção nos anos 1970, através da análise das trilhas sonoras realizadas por ele em especial nos filmes $O$ Poderoso Chefão (Francis Ford Coppola, 1972) e Apocalypse Now (Francis Ford Coppola, 1979).

Os estudos do som cinematográfico chegam então ao século XXI como um promissor campo de pesquisa em emergência. Porém, até o final do século passado, pode ser observado que no Brasil essa área não acompanhou de forma assídua esse percurso de desenvolvimento, possuindo baixa representatividade, e sendo caracterizada por trabalhos escassos e esporádicos. Apenas ao longo dos anos 1990 que começaram a surgir timidamente mais pesquisas sobre o tema, representadas principalmente pelas teses e dissertações a pouco mencionadas.

Como documentos, as teses e dissertações são partes importantes da literatura científica, pois mostram as preocupações dos pesquisadores quanto à configuração do campo em períodos específicos ou ao longo de uma trajetória, ao mesmo tempo em que podem apontar problemas disciplinares, bem como teorias e metodologias utilizadas pela área. [...] Entretanto, por não contarem com um sistema de publicação e distribuição comercial, teses e dissertações impressas podem ser consideradas literatura cinzenta (LC), devido ao escasso número de cópias, o que acarreta pouca visibilidade e dificuldade de acesso. (VANZ; BRAMBILLA; RIBEIRO; STUMPF, 2007: 54)

Como entusiasta do som no cinema, desde a primeira pesquisa realizada em meu trabalho de conclusão de curso em 2009, denominado O Universo Profissional das Etapas da Produção Sonora Cinematográfica, tive grande dificuldade em encontrar bibliografia especializada sobre o assunto e, portanto, tinha o hábito de afirmar que haviam poucos materiais em língua portuguesa a respeito do universo sonoro no cinema. Não satisfeito, ao continuar a investigação das nuances da literatura da área, e após participar de congressos e encontros de cinema, comecei a perceber a quantidade de trabalhos que existiam, ou que surgiram ao longo dos últimos anos, ou que também estavam sendo realizados. Logo, é a partir dessa dificuldade encontrada na busca pelas referências básicas da monografia citada que surgiu o estímulo para conceber um projeto que organizasse esse material, facilitasse o contato e diminuísse o desgaste da busca de uma bibliografia em língua portuguesa que até 
então se encontrava dispersa.

Desta forma, a compreensão do status quo da pesquisa brasileira contemporânea sobre o assunto é fundamental para justificar o rompimento do mito de que o som cinematográfico é pouco estudado no país. E mais, a organização e investigação desse material propicia e facilita o surgimento de novas idéias, pontos de partida, projetos, discussões e análises. Este é portanto um trabalho inédito no Brasil que, através das informações reunidas, proporcionará uma ampla fonte de auxílio para o aperfeiçoamento e maximização do potencial dos estudos nacionais sobre o som no cinema.

Para isso, foram selecionados os livros, as teses, as dissertações e os artigos acadêmicos nacionais que contemplam o universo sonoro cinematográfico, publicados no Brasil no período entre os anos 2001 e 2011, e que articulam essencialmente questões que não são específicas da trilha musical. A estrutura metodológica utilizada é a da revisão sistemática.

O primeiro capítulo deste trabalho dedica-se exclusivamente à explicação passo a passo desse método aplicado, o qual parte desde a formulação do problema, até a localização, seleção e avaliação crítica dos estudos, a coleta, análise e apresentação dos dados, a interpretação dos resultados e o aprimoramento da pesquisa.

No segundo capítulo é onde está elaborado o conteúdo principal do trabalho, dividido em três etapas. A primeira é referente à evolução quantitativa do levantamento bibliográfico realizado, listado de acordo com o ano de publicação dos materiais. Neste momento, preferiuse não mencionar apenas os títulos dos artigos para que haja uma melhor fluidez na leitura. Mas serão indicados os títulos dos livros, teses e dissertações, os locais onde os materiais foram publicados, bem como os autores e uma rápida descrição do conteúdo de cada trabalho. A segunda etapa explora as tendências temáticas averiguadas entre os trabalhos e, portanto, seus conteúdos estarão melhores expostos e relacionados. E a terceira, relata o perfil dos estudos, focando tanto nos locais onde foram publicados, quanto nos pesquisadores autores.

$\mathrm{Na}$ conclusão é apresentado um aparato geral reflexivo do caminho percorrido no trabalho, incluindo uma breve exposição sobre o portal online de registro e divulgação dos resultados dessa pesquisa, intitulado “Artesãos do Som” (www.artesaosdosom.org).

Devido a grande quantidade de referências, a bibliografia deste trabalho está dividida primeiramente de acordo com os capítulos estipulados. Logo após, está a webgrafia e as bibliografias de apoio. Já os trabalhos inseridos no levantamento bibliográfico da pesquisa brasileira contemporânea sobre o som no cinema estão dispostos nos anexos. Assim, para uma leitura mais proveitosa, sugere-se que o leitor esteja atento a esses anexos que contém a lista dos materiais organizados de acordo com as propostas expostas ao longo do texto. 


\section{METODOLOGIA}

Para mapear, discutir e analisar o status quo dos estudos brasileiros contemporâneos sobre o som cinematográfico, esta pesquisa utilizou-se de bases conceituais da estrutura metodológica do domínio da revisão sistemática. Conforme CASTRO (2001: 1), a revisão sistemática é uma revisão planejada para responder a uma pergunta específica e que utiliza métodos explícitos e sistemáticos para identificar, selecionar e avaliar criticamente determinado universo de estudo, além de também coletar e analisar os dados dos estudos incluídos na revisão.

Apesar de ser mais frequentemente aplicada nas áreas das políticas sociais e nas ciências médicas, buscando um controle de qualidade da informação gerada pelo alto número de pesquisas desenvolvidas e publicadas por ano, a revisão sistemática já foi empregada em diversificadas áreas (JOHNSON; SCOTT-SHELDON; SNYDER; NOAR; HUEDOMEDINA, 2007). Mesmo hoje sendo possível encontrar mais de um método para sua realização, esta dissertação se baseará nos passos básicos de estruturação recomendados pela Colaboração Cochrane (ALDERSON; GREEN; HIGGINS, 2004), organização ligada à área da saúde mas de grande referência metodológica para a preparação e elaboração de revisões sistemáticas. Da mesma forma, é intenção buscar um rigor sugerido por HEMINGWAY (2009) de explicar cuidadosamente como os estudos foram selecionados, avaliados e integrados.

Os sete passos básicos aconselhados pela Colaboração Cochrane para estruturar uma revisão sistemática já relacionados com a pesquisa realizada neste trabalho são:

\section{1) Formulação do problema:}

Tal qual acontece com qualquer investigação, a primeira e mais importante decisão para a preparação de uma revisão é determinar o seu foco (Light $1984 b^{25}$ ). Isso é melhor feito por meio de perguntas claramente enquadradas. Tais perguntas são essenciais para determinar a estrutura de uma revisão (Jackson $1980^{26}$, Cooper 1984 ${ }^{27}$, Hedges $1994^{28}$ ). Especificamente, elas vão orientar grande parte do processo de revisão, incluindo as estratégias para localizar e selecionar estudos ou dados, para avaliar criticamente sua pertinência e validade, e para a análise de variação entre seus resultados. ${ }^{29}$ (ALDERSON; GREEN; HIGGINS, 2004: 25)

\footnotetext{
25 Light 1984b. Light RJ, Pillemer DB. Organizing a reviewing strategy. In: Summing Up: The Science of Reviewing Research. Cambridge, Massachusetts: Harvard University Press, 1984; 13-31.

26 Jackson 1980. Jackson GB. Methods for integrative reviews. Rev Educ Res 1980; 50:438-60.

27 Cooper 1984. Cooper HM. The problem formulation stage. In: Cooper HM, editor. Integrating Research. A Guide for Literature Reviews. Newbury Park: Sage Publications, 1984; 19-37.

28 Hedges 1994. Hedges LV. Statistical considerations. In: Cooper H, Hedges LV, editors. The Handbook of Research Synthesis. New York: Russell Sage Foundation, 1994; 30-3.

29 Tradução do autor.
} 
Desta forma, as perguntas essenciais para determinar a estrutura da revisão sistemática aqui proposta são:

- Quais e quantos são de fato os trabalhos brasileiros contemporâneos sobre o som no cinema?

- Quais os assuntos e objetos de estudo dentro da questão da trilha sonora cinematográfica presentes nos trabalhos?

- Quais as principais temáticas abordadas?

- Onde estão publicados esses materiais?

- Qual o perfil da pesquisa e dos autores dos trabalhos?

2) Localização e seleção dos estudos:

Não existe uma única fonte de busca de estudos. Para identificar todos os estudos relevantes é necessário pesquisar nas bases de dados electrónica [...], verificar as referências bibliográficas dos estudos relevantes, solicitar estudos de especialistas e pesquisar manualmente algumas revistas e anais de congressos. Cada uma das fontes usadas deve estar identificada em relação ao método que se utilizou para encontrá-la. (POCINHO, 2008: 15-16)

Em geral, é para os revisores decidirem qual projeto(s) de estudo incluir em sua revisão. A maioria das revisões Cochrane incluem apenas ensaios aleatórios ou semialeatórios. Algumas revisões são mais restritivas e incluem somente ensaios aleatórios, enquanto outras são menos, incluindo outros projetos de estudo, especialmente quando poucos ensaios aleatórios que abordam o tema da avaliação são identificados. ${ }^{30}$ (ALDERSON; GREEN; HIGGINS, 2004: 42)

Para localizar a bibliografia brasileira contemporânea sobre o som no cinema, um extenso levantamento foi realizado sobretudo através da busca por palavras-chave em plataformas de banco de dados acadêmicos, portais de produção científica e anais de congressos que permitem a localização de materiais por meio de ferramentas de busca virtual.

As palavras-chave utilizadas foram estipuladas a partir do Vocabulário Controlado da USP, o qual possui uma macroestrutura contendo as relações lógico-semânticas explícitas entre as áreas, subáreas e as terminologias em seus diferentes níveis. Por ser uma lista de assuntos utilizada para a indexação de recursos de informação no Banco de Dados Bibliográficos da USP - DEDALUS -, abranger as áreas do conhecimento inerentes às atividades de ensino, pesquisa e extensão da Universidade de São Paulo, e estar sendo aprimorado desde a sua concepção em 1985 (UNIVERSIDADE DE SÃO PAULO, 2006), o Vocabulário Controlado USP torna-se então um bom parâmetro acadêmico para esta

30 Tradução do autor. 
finalidade. Logo, as palavras-chave encontradas relacionadas ao som no cinema foram: "cinema"; "som"; "dublagem"; "efeitos sonoros no cinema"; "edição de som"; "som direto"; "trilha sonora de filmes"; "trilha musical de filmes". O caminho percorrido até alcançar essas terminologias partiu das hierarquias de vocábulos definidas por áreas do conhecimento e agrupadas de acordo com a macroestrutura presente na lista, iniciando pela grande área das Ciências Humanas e desdobrando-se no seguinte percurso temático:

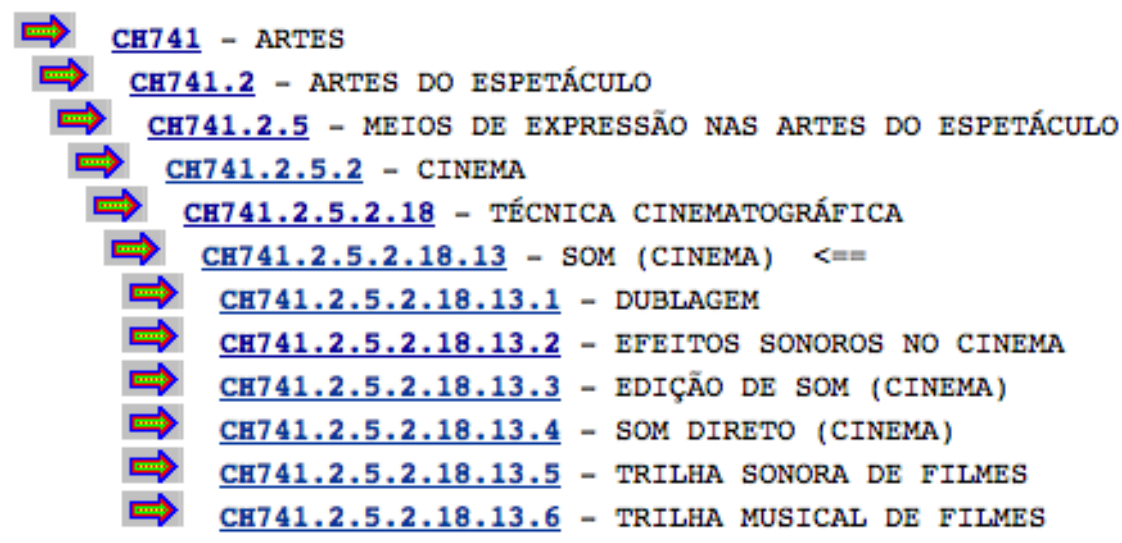

Com a necessidade de atingir a maior quantidade de trabalhos relevantes possíveis e revigorar esta dissertação, foram ainda acrescentadas outras palavras-chave na busca dos trabalhos brasileiros contemporâneos sobre o som no cinema, como: "trilha sonora"; "música"; "voz"; "ruído"; "foley"; "silêncio"; "áudio" e "audiovisual”.

A principal plataforma de pesquisa de dados utilizada foi a Plataforma Lattes do Conselho Nacional de Desenvolvimento Científico e Tecnológico (CNPq). Para completar o levantamento ainda foram conferidas a Biblioteca Digital Brasileira de Teses e Dissertações (BDTD); o banco de teses da Coordenação de Aperfeiçoamento de Pessoal de Nível Superior (CAPES); a Biblioteca Online de Ciências da Comunicação (BOCC); os bancos de teses e dissertações da Universidade de São Paulo (USP), da Pontifícia Universidade Católica de São Paulo (PUC-SP), da Universidade Estadual de Campinas (UNICAMP), da Universidade de São Carlos (UFSCar), Universidade Federal Fluminense (UFF), da Universidade Federal do Rio de Janeiro (UFRJ), da Universidade do Estado do Rio de Janeiro (UERJ), da Universidade Federal de Minas Gerais (UFMG) e da Universidade Federal do Paraná (UFPR); o catálogo da Biblioteca Paulo Emilio Salles Gomes do Centro de Documentação e Pesquisa da Cinemateca Brasileira; a plataforma JSTOR; o Directory of Open Acces Journals (DOAJ); portais de produção científica como o Portal de Produção Científica em Comunicação (UNIVERCIENCIA) e seu Portal de Revistas de Acesso Aberto em Ciências da Comunicação; o Mnemocine (portal online dedicado ao ensino e à pesquisa do universo 
audiovisual); incluindo o catálogo de revistas acadêmicas em comunicação e das teses e dissertações em comunicação no Brasil do Núcleo de Pesquisa em Informação, Tecnologias e Práticas Sociais (INFOTEC) da Universidade do Rio Grande do Sul (UFRGS); a Sociedade Brasileira de Estudos de Cinema e Audiovisual (SOCINE); a Sociedade Brasileira de Estudos Interdisciplinares da Comunicação (INTERCOM); a Sociedade de Engenharia de Áudio (AES-Brasil); a Associação Nacional de Pesquisa e Pós-Graduação em Música (ANPPOM); e a Associação Nacional dos Programas de Pós-Graduação em Comunicação (COMPÓS).

Posteriormente, para ainda verificar a possível existência de outros documentos não presentes nessas bases de dados virtuais examinadas, preocupou-se também em fazer uma revisão das referências bibliográficas dos próprios materiais encontrados. Essa revisão auxiliou principalmente na descoberta de trabalhos provenientes de outras áreas de atuação como, por exemplo, a da Fonoaudiologia, inserida na grande área das Ciências da Saúde.

Já em relação à seleção dos estudos, dos diversos documentos encontrados foram separados aqueles publicados dentro dos quatro formatos de publicação literária acadêmica científica brasileira alvos de investigação desta dissertação: livros, teses, dissertações e artigos. E ainda, incluídos em um recorte temporal atual: trabalhos publicados ao longo dos primeiros onze anos do século XXI. A ideia foi fazer o levantamento e analisar a produção bibliográfica do primeiro ano do século XXI até o ano de início dessa pesquisa de mestrado. Esse período abrangido, do ano 2001 até o ano 2011, representa portanto, um ciclo contemporâneo de pesquisa.

\section{3) Avaliação crítica dos estudos:}

"Com a avaliação crítica determinamos quais são os estudos válidos que irão ser utilizados na revisão; e os que não preenchem os critérios de validade são citados e explicado o porquê de sua exclusão" (CASTRO, 2001: 2).

A avaliação crítica da pesquisa a respeito dos livros, teses, dissertações e artigos acadêmicos brasileiros sobre o som no cinema publicados no período do ano 2001 até 2011, se ateve a alguns focos para a formulação da revisão proposta. São eles: trabalhos escritos em língua portuguesa e publicados no Brasil; trabalhos onde o som cinematográfico, ou algum assunto inerente à experiência sonora no cinema, seja a núcleo principal de estudo; e trabalhos que articulam essencialmente questões que não são específicas da trilha musical. E mais, não serão analisados materiais de revistas ou catálogos que não possuam o identificador de publicações seriadas aceito internacionalmente, mais conhecido como ISSN (International 
Standard Serial Number) ${ }^{31}$. Esses interesses de análise definidos surgem devido à necessidade de delimitar o objeto de pesquisa.

Vale reiterar que a opção por não investigar trabalhos que articulam questões exclusivas da trilha musical aparece uma vez que o campo de estudo sobre a música no cinema além de muito amplo, possui questões intrínsecas à linguagem musical que competem especialmente aos pesquisadores da área de música e aos músicos propriamente ditos. Para se ter uma breve noção da grande quantidade de publicações sobre a trilha musical no cinema, na primeira listagem do levantamento a qual foi realizada sem filtros e focos peculiares, constatou que mais que o dobro dos materiais tratavam de questões inerentes à música no cinema, sendo analisadas também por outras áreas que não só a da própria música, como por exemplo, a da comunicação, da história, de multimeios, da letras, etc. Porém, o fato de algum trabalho utilizar teorias oriundas do universo da música e aplicá-las em análises referentes a alguma perspectiva sonora ou audiovisual no cinema, que não restritamente à musical, não o excluirá da investigação.

Aproveitando para salientar uma questão já muito comentada, mas mesmo assim importante de ser reforçada, sobre o fato de no Brasil existir um hábito cultural de remeter o termo "trilha sonora" a apenas a música do filme, ou seja, a trilha musical. Certamente este costume restringe a compreensão e a reflexão sobre a complexidade e importância da produção e construção sonora como um todo no cinema. Desta forma, busca-se contribuir com a expansão e valorização dos demais elementos - voz, ruído e silêncio - e de outras possíveis temáticas de estudo sobre a trilha sonora cinematográfica.

Portanto, não serão analisados livros, teses, dissertações e artigos que foram publicados no exterior por pesquisadores brasileiros; nem trabalhos estrangeiros traduzidos para o português; nem resumos publicados em anais de congressos; nem trabalhos onde o som, ou alguma de suas especificidades no cinema, não seja o foco principal de análise; e nem trabalhos que articulam questões exclusivas da música no cinema.

Todavia, os trabalhos que não pertencem ao conjunto de interesses definidos citados, mas que foram encontrados ao longo do levantamento bibliográfico realizado, não foram descartados e estão listados no Anexo VII dessa dissertação, visto que podem ser úteis para o leitor ou para futuras pesquisas.

4) Coleta de dados:

31 Neste caso, as únicas exceções são três catálogos de mostras de cinema que, apesar de não possuírem ISSN, foram mencionados no tópico "Evolução Quantitativa" do próximo capítulo desta dissertação. 
O formulário de coleta de dados tem pelo menos três funções importantes. Primeiramente, a forma de coleta de dados está diretamente relacionada com a questão crítica formulada e a avaliação planejada dos estudos incluídos e, portanto, fornece uma representação visual delas. Em segundo lugar, o formulário de coleta de dados é o registro histórico da multiplicidade de decisões (e alterações de decisões) que ocorrem durante todo o processo de revisão. Terceiro, o formulário de coleta de dados é o repositório de dados do qual as análises surgirão. ${ }^{32}$ (ALDERSON; GREEN; HIGGINS, 2004: 61)

A coleta de dados se concentrou nas informações necessárias para responder as questões propostas no primeiro passo dessa revisão. Inicialmente se ateve ao número de trabalhos. Em seguida, foi coletado o ano de publicação dos materiais; a instituição e o programa de pósgraduação onde as teses e dissertações foram desenvolvidas; os anais e as revistas acadêmicas onde os artigos foram publicados; o gênero e a atuação profissional dos autores dos trabalhos.

Por intermédio da leitura técnica, que é uma "leitura direcionada para certas partes do documento onde vai-se encontrar elementos especialmente importantes para a identificação do assunto ou assuntos do documento," consistindo na "estratégia clássica de leitura para análise de assunto" (DIAS; NAVES, 2007: 52), foram extraídos não só os assuntos ou temas, como também os subtemas, os objetos e os corpus específicos de estudo dos trabalhos investigados. As partes dos textos consideradas foram as propostas por DIAS e NAVES (2007). São elas: o título, o subtítulo, o sumário, o resumo, o prefácio, a apresentação, os títulos dos capítulos, a introdução, a conclusão, os índices e a bibliografia. Evidentemente respeitando as diferenças particulares de cada formato de trabalho, já que por exemplo, no caso dos artigos, conta-se geralmente apenas com o título, subtítulo, resumo e bibliografia. Os termos "tema", "subtema", "objeto" e "corpus" estão assim compreendidos:

A definição de tema pode parecer, à primeira vista, complexa e mesmo confusa; alguns autores tratam 'tema' como sinônimo de 'assunto' ou 'objeto' de discussão, outros o definem como um elemento semântico construído durante o percurso de uma investigação. De qualquer modo, as abordagens e definições podem se complementar e contribuir umas com outras na conceituação de tema [...]. Em um texto, os temas são engendrados e dispostos em uma cadeia significante, constituindo um percurso temático, em que os subtemas se organizam em conjuntos de sentidos. [...] O objeto é algo que pode ser percebido através dos sentidos ou pela inteligência. Nesse sentido, o objeto é pensado a partir de um conhecimento formulado em uma determinada disciplina, área ou assunto específico; e o sujeito (pesquisador), é levado por uma curiosidade científica à investigação. Ao visualizar o objeto, o pesquisador o toma iniciando assim um processo de recorte espacial e temporal da temática a ser analisada. [...] O corpus é identificado quando a limitação do objeto é definida por um recorte espacial ou temporal (ou espaço-temporal), podendo assim ser representativo para o exame da temática proposta. $\mathrm{O}$ corpus de uma pesquisa refere-se aos objetos linguísticos ou campos semânticos indicados no texto e relacionados ao tema e à questão de pesquisa. [...] Campo semântico (ou nacional ou conceitual) é a estrutura formada por organização lexical. Esta organização é formada por termos

32 Tradução do autor. 
semânticos empregados pelo sujeito (no caso o pesquisador). [...] A compreensão de campo semântico e definição de léxico, juntamente com a terminologia (específica, particular de cada um) empregada por cada pesquisador na elaboração do texto que compõe cada resumo, auxilia nos na identificação de temas, subtemas e objetos nos resumos analisados. (VALENCIA, 2005: 77, 79, 83, 85, 86 e 87)

Para possibilitar o contato com as partes dos textos consideradas, foi preciso compilar o material bibliográfico levantado. Este processo foi realizado acima de tudo por meio da ferramenta de busca do Google, que possibilitou encontrar os trabalhos disponíveis e dispersos na internet. Mas também, por intermédio dos bancos de dados das bibliotecas digitais de dissertações e teses das universidades que disponibilizam online os trabalhos para consulta, como é o caso da USP, UNICAMP, UFF, UFMG e UFPR, por exemplo; do banco de teses da CAPES; do "Portal Domínio Público" do Ministério da Educação; e dos portais digitais das revistas acadêmicas localizadas, sociedades de estudos da área (SOCINE, INTERCOM e ANPPOM). Além disso, através da visita às bibliotecas das universidades onde estão presentes os materiais que não foram encontrados nos passos anteriores, e ainda mediante o contato direto com o pesquisador-autor ${ }^{33}$.

5) Análise e apresentação dos dados:

"As análises podem ser narrativas, tal como um resumo estruturado e a discussão das características e descobertas dos estudos, ou quantitativa, que envolve análises estatísticas" ${ }^{34}$ (ALDERSON; GREEN; HIGGINS, 2004: 6).

Orientada pelas informações que esclarecem as questões expostas no primeiro passo dessa revisão, a proposta é de analisar quantitativa e narrativamente a pesquisa brasileira contemporânea sobre o som no cinema. Assim, englobando a descrição da evolução numérica das publicações ao longo do período estudado, a investigação no âmbito do perfil de produção dos materiais, que envolve o local de publicação e as possíveis relações existentes entre os trabalhos desenvolvidos nas mesmas universidades, cursos de pós-graduação, instituições e revistas acadêmicas, o gênero e a atuação profissional dos autores, etc.

Após a identificação e observação dos principais assuntos ou temas, subtemas, objetos e corpus específicos de estudos dos trabalhos, foram formuladas e propostas categorias que

\footnotetext{
33 Já adiantando, apenas três trabalhos não foram encontrados por completo. São eles: a dissertação "Análise dos Padrões de Voz no Cinema: a comunicação oral humana em duas versões de The Nutty Professor" (CASTRO, 2001), a qual obteve-se apenas o título, o resumo e alguns parágrafos citados em outra pesquisa; a dissertação "O Surround e a Espacialidade Sonora no Cinema" (COSTA, 2004a) a qual obteve-se apenas o resumo, o sumário, a introdução e a bibliografia; e o artigo "O Sonho de Edison: o advento do som sincronizado" (CARRASCO, 2003) o qual obteve-se apenas o título e a informação de que ele foi retirado do capítulo homônimo da dissertação de mestrado do mesmo autor, CARRASCO (1993).

34 Tradução do autor.
} 
possam representar os principais tópicos temáticos julgados mais condizentes com a realidade brasileira contemporânea dos estudos do som no cinema. A ideia é então contemplar classificações que reunam e esclareçam a variedade de conteúdo do material bibliográfico levantado. São nessas categorias estipuladas que estão localizadas análises sobre a forma como os assuntos ou temas, subtemas, os objetos e os corpus específicos de estudo são abordados pelos pesquisadores. Para melhor esclarecer esse processo, parte-se do princípio que a grande área aqui abordada é a do "Som no Cinema", e as categorias estipuladas simbolizam uma espécie de "área" a qual grupos de trabalhos dialogam entre si. Dentro disso, cada trabalho ainda possui seu assunto ou tema, seus subtemas, objetos e corpus específicos de estudos particulares.

A apresentação dos dados é realizada mediante três dos procedimentos: tabelas, gráficos e representação escrita. Então, além de serem apresentados em forma de texto, os dados foram ordenados em tabelas e gráficos que constituem a quantidade de trabalhos desenvolvidos por ano e sua linha numérica evolutiva ao longo do período estudado; a porcentagem e a quantidade total de teses e dissertações por universidade; a quantidade total de teses e dissertações por curso de pós-graduação; a divisão das grandes áreas de conhecimento e os cursos de pós-graduação identificados a partir do modelo da Capes; a quantidade total de artigos por locais de publicação; a quantidade total de trabalhos por autor; a distribuição dos temas, subtemas, objetos e corpus específicos de estudo perante o formato, o título, o autor e o ano dos trabalhos.

\section{6) Interpretação dos resultados}

"São determinadas a força da evidência encontrada, a aplicabilidade dos resultados, as informações sobre custo e a prática corrente e tudo mais que seja relevante para determinação clara dos limites entre riscos e benefícios" (POCINHO, 2008: 16).

As interpretações dos resultados da pesquisa ocorrem por meio da compreensão dos dados coletados e, consequentemente, das conclusões provenientes das questões estabelecidas no primeiro passo dessa revisão. Essas interpretações estarão dispostas ao longo dos itens do próximo capítulo dessa dissertação, onde é investigado a evolução quantitativa, as tendências temáticas e o perfil da pesquisa brasileira contemporânea sobre o som no cinema, e também nas próprias considerações finais do trabalho.

7) Aprimoramento e atualização da revisão

“Uma vez publicada a revisão sofrerá críticas e receberá sugestões que devem ser 
incorporadas às edições subseqüentes, caracterizando uma publicação viva, e ainda ser atualizada cada vez que surjam novos estudos sobre o tema" (CASTRO, 2001: 2).

Para expandir os resultados da pesquisa proposta foi idealizado e elaborado um sítio eletrônico de registro e divulgação dos resultados do trabalho com o nome de "Artesãos do Som" (www.artesaosdosom.org). O objetivo é que esse portal online possibilite a ampliação da revisão sistemática a partir de críticas e sugestões de interessados em colaborar com possíveis edições futuras da pesquisa, facilitando os meios de comunicação entre os pesquisadores e agregando, em um local acessível, as informações que até então estavam dispersas. 


\section{A PESQUISA BRASILEIRA CONTEMPORÂNEA SOBRE O SOM CINEMATOGRÁFICO}

\subsection{Evolução Quantitativa}

A representatividade da pesquisa brasileira sobre o som cinematográfico até o final do século passado foi constituída por trabalhos incipientes, porém escassos e esporádicos, como observado anteriormente. Nos onze anos seguintes, um grande salto: o interesse acadêmico em estudar o som no cinema se expandiu de forma considerável no país. Assim, esses primeiros anos do século XXI deram início à consolidação dos estudos do som cinematográfico como uma realidade também no Brasil, atingindo uma evolução quantitativa inédita na história até então. Na tabela abaixo é possível notar os valores numéricos desse progresso.

TABELA I

Levantamento bibliográfico quantitativo realizado por ano (2001-2011) ${ }^{35}$ :

\begin{tabular}{|l|c|c|c|c|c|c|c|c|c|c|c|c|}
\hline Materiais/Ano & 2001 & 2002 & 2003 & 2004 & 2005 & 2006 & 2007 & 2008 & 2009 & 2010 & 2011 & TOTAL \\
\hline LIVROS & - & - & 1 & - & - & - & - & 1 & - & - & - & 2 \\
\hline TESES & - & - & - & - & 1 & 1 & - & - & - & 2 & 1 & $\mathbf{5}$ \\
\hline DISSERTAÇÕES & 1 & - & 1 & 1 & 2 & 2 & 2 & 3 & 3 & 3 & 3 & $\mathbf{2 1}$ \\
\hline ARTIGOS & - & - & 7 & 3 & 1 & 2 & 7 & 9 & 8 & 8 & 19 & $\mathbf{6 4}$ \\
\hline TOTAL & $\mathbf{1}$ & - & $\mathbf{9}$ & $\mathbf{4}$ & $\mathbf{4}$ & $\mathbf{5}$ & $\mathbf{9}$ & $\mathbf{1 3}$ & $\mathbf{1 1}$ & $\mathbf{1 3}$ & $\mathbf{2 3}$ & $\mathbf{9 2}$ \\
\hline
\end{tabular}

A produção acadêmica do período estudado começa tímida. Em 2001 foi descoberta apenas uma dissertação: “Análise dos Padrões de Voz no Cinema: a comunicação oral humana em duas versões de The Nutty Professor" de Luciana Castro, defendida pelo Programa de PósGraduação Educação em Ciências e Saúde da Universidade Federal do Rio de Janeiro (UFRJ). Trabalho singular no ano de 2001, estuda padrões da voz no cinema sobre a ótica da Fonoaudiologia.

O ano de 2002 passa silencioso e o ano de 2003 acaba se tornando o grande marco da retomada das discussões no novo século sobre perspectivas do som no cinema que vão além das especificidades da trilha musical. O mérito maior está no lançamento do primeiro livro nacional que propôs uma reflexão teórica acerca do som no cinema mudo e sonoro e sua relação com a imagem. É ele: "Som-Imagem no Cinema" de Luiz Adelmo Manzano,

35 Confira a lista bibliográfica completa distribuída por ano no Anexo I desta dissertação. 
publicado pela editora Perspectiva. O livro é proveniente da dissertação de mestrado do autor defendida em 1999 na Escola de Comunicações e Artes da Universidade de São Paulo (ECA/USP), e averigua o papel do som no cinema, aplicando os conceitos estudados de som dentro do filme em duas obras do diretor alemão Fritz Lang: Metropolis (1925-1926) e $M$, o Vampiro de Düsseldorf(1931).

2003 é o ano que surge também os primeiros trabalhos acadêmicos de Fernando Morais da Costa. Sua dissertação intitulada "Som no Cinema, Silêncio nos Filmes: o inexplorado e o inaudito", defendida nesse ano no Programa de Pós-Graduação em Comunicação da Universidade Federal Fluminense (UFF). Nela, o autor ao mesmo tempo que faz um resgate do processo de junção dos sons com as imagens no cinema, pensa o silêncio como elemento componente da trilha sonora, e também dedica um capítulo inteiro para refletir sobre o som na teoria clássica do cinema e sua conquista como novo campo de estudo no meio acadêmico. Dos sete artigos computados em 2003, cinco são de autoria de Fernando Morais da Costa. Sendo dois publicados nos livros do V e VI Encontros da SOCINE, discorrendo respectivamente sobre a importância dos ruídos e do silêncio na composição sonora cinematográfica, e sobre modos alternativos de utilização da voz no cinema. Um, publicado nos anais da INTERCOM, questionando a primazia da visão nos processos comunicacionais e a importância da audição na infância. Outro publicado na revista científica Ecos Revista da Escola de Comunicação Social da Universidade Católica de Pelotas (ECOS/UCPel), analisando o período de inserção do som no cinema, e discutindo o potencial do som diante a uma suposta preponderância da imagem no audiovisual. E o último, publicado nos anais do I Encontro Nacional da Rede Alfredo de Carvalho realizado pela Associação Brasileira de Pesquisadores de História da Mídia (Alcar), segue na mesma linha questionando a hegemonia da imagem e recuperando o momento histórico do advento do som no cinema. Todos de certa forma articulando ideias derivadas da dissertação do autor.

Há ainda o artigo de Suzana Dobal sobre o uso do silêncio na obra de Robert Bresson, publicado no livro do V Encontro da SOCINE. O sétimo artigo restante fica a cargo de Ney Carrasco, que propõe neste texto publicado na revista ArtCultura do Instituto de História e do Programa de Pós-graduação em História da Universidade Federal de Uberlândia (UFU), resgatar as principais experiências de união entre som e imagem que possibilitaram o advento e a consolidação do som no cinema.

Os próximos dois anos acabam não conseguindo manter a risca os números gerais do propulsor ano de 2003, diminuindo para menos da metade da quantidade total de materiais publicados. De nove trabalhos publicados em 2003 (um livro, uma dissertação e sete artigos), 
baixou para quatro em 2004 (uma dissertação e três artigos), número total que manteve em 2005 (uma tese, duas dissertações e um artigo). A queda da quantidade total de materiais promulgados nesses dois últimos anos citados está relacionada à baixa na produção de artigos. Este formato de trabalho foi o que mais regrediu em quantidade, atingindo em 2005 sua menor marca do período depois dos anulados anos de 2001 e 2002, como pode ser notado no gráfico a seguir:

\section{GRÁFICO I}

Levantamento bibliográfico quantitativo realizado por ano (2001-2011):

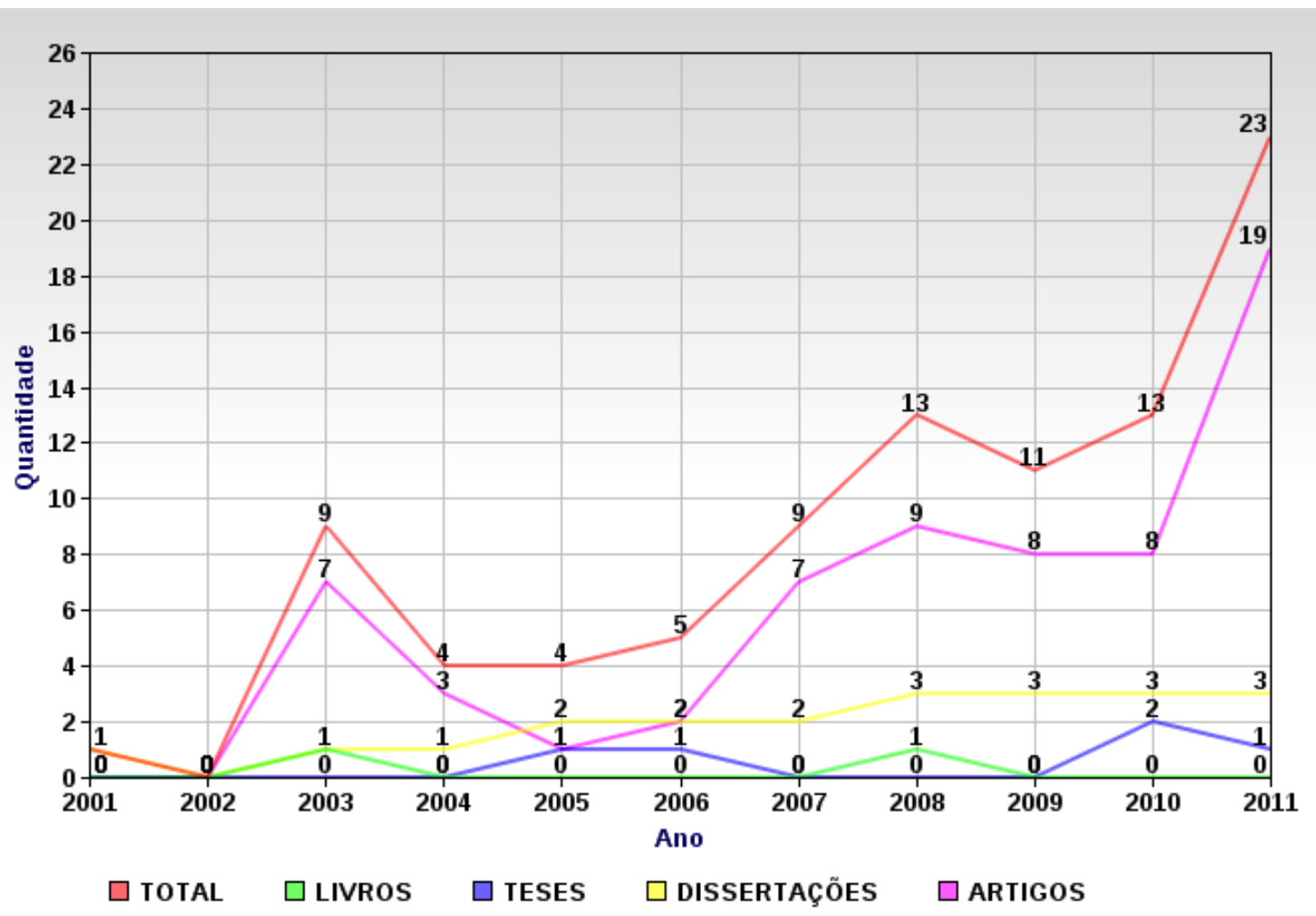

Em 2004 houve apenas a dissertação "O Surround e a Espacialidade Sonora no Cinema" que pesquisa a tecnologia e as características técnicas do som multicanal no cinema, defendida por Nélio Costa no Programa de Pós-Graduação em Artes da Universidade Federal de Minas Gerais (UFMG). E mais três artigos: um de Eduardo Santos Mendes publicado na revista Teorema - Crítica de Cinema do Núcleo de Estudos de Cinema de Porto Alegre, apresentando diferentes padrões de uso e métodos de análise da relação som/imagem no cinema. Outro de Fernando Morais da Costa, realçando o espaço do silêncio nos estudos sobre a trilha sonora cinematográfica, publicado na revista Gragoatá do Programa de PósGraduação em Letras da UFF. E o último, de autoria de Luciene Belleboni, publicado nos anais do II Encontro Nacional da Rede Alfredo de Carvalho da Alcar, e que discute a difícil relação entre as linguagens imagética e sonora no audiovisual. 
Ainda que com um baixo número de trabalhos, merece ser destacado no ano de 2004 o aparecimento de outro modelo de documento que é também uma contribuição literária para os estudos em língua portuguesa sobre o universo sônico do cinema. Mas, não está aqui contabilizado nem analisado devido sua informalidade perante o sistema de padronização internacional ISSN (International Standard Serial Number). Mesmo conciso, o catálogo da mostra cinematográfica intitulada "Sound Design: Projeto de Som", especial sobre a trilha sonora dos filmes, configura a primeira iniciativa, nesse molde, de proporcionar ao público o contato com informações de pesquisas de especialistas e estudiosos no assunto. A mostra, que contou com a curadoria de Eduardo Santos Mendes, aconteceu dos dias 14 a 19 de dezembro no Centro Cultural da cidade de São Paulo (CCSP) em decorrência à inauguração do até então "novo sistema de som"36 de sua sala de exibição Lima Barreto. No catálogo encontram-se dois textos. O primeiro, de autoria do próprio Eduardo Santos Mendes, articula aspectos da forma de produção e de pensamento da trilha sonora no cinema a partir da figura e do profissional "sound designer" ou "projetista de som", como ele designa, com a questão da distribuição espacial do som nas salas de cinema e os filmes exibidos na mostra. E o segundo, de Luiz Adelmo Manzano, sobre a evolução do som cinematográfico, principalmente atrelado à produção sonora diante da tecnologia digital, fazendo novamente uma ligação com o trabalho de som do filme M, o Vampiro de Düsseldorf (Fritz Lang, 1931). Vale ressalvar o fato de ser um hábito comum mostras cinematográficas lançarem catálogos, porém até o ano de 2004 não há registro de outras mostras dedicadas exclusivamente à apreciação, reflexão e compreensão da trilha sonora no cinema, e que também tenham distribuído esse tipo de material textual.

Em 2005 surge a primeira tese revelada no período analisado, o doutorado de Luiz Adelmo Manzano nomeado "O Som no Cinema: da edição de som ao sound design - evolução tecnológica e produção brasileira". Defendido no Programa de Pós-Graduação em Ciências da Comunicação da USP, o trabalho consiste fundamentalmente em uma rica e ampla abordagem sobre o uso da trilha sonora na narrativa cinematográfica desde o advento do cinema sonoro, e como esse uso se modifica a partir do progresso tecnológico que expande as possibilidades de construção dos filmes. Há também entrevistas que registram experiências vivenciadas por renomados profissionais atuantes no cinema brasileiro no setor do som, principalmente na área de pós-produção, revelando a evolução dos procedimentos de trabalho, do pensamento sonoro e da concepção sonora cinematográfica no país até o início do século XXI.

Neste mesmo ano o número de dissertações aumenta para dois. São elas: "Um Estudo da Performance da Oralidade no Cinema: registros da voz na linguagem documental", defendida

\footnotetext{
36 Um sistema Dolby Digital.
} 
por Elen Döppenschmitt no Programa de Estudos Pós-Graduados em Comunicação e Semiótica da Pontifícia Universidade Católica de São Paulo (PUC-SP), e que estuda a importância da voz no cinema documentário. E a intitulada "Introdução à Arqueologia da Escuta ou o Nascimento do Cinema Sonoro a partir do Espírito da Ópera" de Ivan Cappeler, que investiga a história dos regimes de escuta relacionados à história do cinema sonoro, e foi defendida no Programa de Pós-Graduação em Comunicação da UFF. Já o número de artigos reduziu, atingindo a marca de apenas um exemplar. De autoria de Eduardo Santos Mendes em parceria com Ivonete Pinto, o texto foi publicado na revista Teorema - Crítica de Cinema e fala sobre o som e a narrativa do filme A Menina Santa (2004) da diretora argentina Lucrécia Martel.

Em 2006 mantem-se a média de uma tese e duas dissertações defendidas. Há um aumento sutil na quantidade total de trabalhos devido a publicação de um artigo a mais que no em 2005. Então, é em 2006 que aparece a segunda tese publicada na década. O doutorado de Fernando Morais da Costa, denominado "O Som no Cinema Brasileiro: revisão de uma importância indeferida", foi obtido no Programa de Pós-Graduação em Comunicação da UFF. Essa tese veio a ser publicada em formato de livro em 2008, e é uma aprofundada investigação do papel desempenhado pelo som em pontos fundamentais da história do cinema no Brasil.

Sobre as dissertações presentes em 2006 tem-se o trabalho de mestrado defendido por Vitória Rocha Amaral no Programa de Pós-Graduação em Fonoaudiologia da PUC-SP. Designado "A Voz na Mise en Scène: o filme Cidade de Deus sob a escuta fonoaudiológica", analisa como a voz e suas qualidades sonoras se associam aos demais elementos da linguagem cinematográfica. E também a pesquisa de Virginia Flores, "O Cinema, uma arte sonora", que estuda basicamente o som e seus modos de utilização no cinema, focando no processo de escuta fílmica, e foi defendida no Programa de Pós-Graduação em Música da Universidade Federal do Rio de Janeiro (UFRJ).

Os dois artigos publicados em 2006 foram: um publicado na revista Significação Revista de Cultura Audiovisual da USP, contendo um resumo da tese de doutorado do autor, Eduardo Santos Mendes, do ano 2000; e outro que resgata o percurso dos "cinematógrafos falantes" ao longo do território brasileiro, em especial entre o período dos anos de 1902 e 1908, e fora publicado no portal online dedicado ao ensino e à pesquisa do universo audiovisual denominado Mnemocine ${ }^{37}$.

37 Há registro da publicação deste mesmo artigo também nos anais do XXIII Simpósio Nacional de História da ANPUH (Associação Nacional dos Professores Universitários de História) em 2005, porém aqui preferiu-se registrá-lo no ano de 2006 como consta apontado no currículo Lattes do autor. 
Depois desses três últimos anos com uma quantidade razoavelmente baixa de publicações, no ano de 2007 a produção bibliográfica da área volta a ser impulsionada para um total de nove trabalhos. O número de dissertações seguiu na média dos últimos dois anos 2005 e 2006 -, contendo duas publicações. São elas: o mestrado de Mariano Alvarez denominado "A Estereofonia Digital: Uma abordagem sobre a técnica, o padrão e a linguagem sonora cinematográfica norte-americana no período de 1991 a 2001”, defendido no Programa de Pós-Graduação em Ciências da Comunicação da USP, e que discute o uso do espaço sonoro no cinema através da tecnologia estereofônica digital. E a dissertação de Alexandre Bräutigam, "Sonologia e Cinema: elementos para análise áudio-visual”, defendida no Programa de Pós-Graduação em Música da UFRJ, e que analisa a trilha sonora cinematográfica a partir de teorias da música eletroacústica.

A quantidade de artigos aumentou para sete, sendo desta vez a principal responsável por revigorar o número total de materiais produzidos até então. Dois deles são oriundos de parte das dissertações de mestrado já mencionadas das autoras Virginia Flores e Elen Döppenschmitt, sendo o da primeira publicado nos anais do XVII Congresso da ANPPOM, discutindo a questão da escuta fílmica; e o da segunda na Revista Unimontes Científica da Universidade Estadual de Montes Claros, articulando a importância da voz no cinema e as trocas entre o registro e as práticas da oralidade a partir do documentário "Adão ou Somos Todos Filhos da Terra" (Walter Salles e Daniela Thomas, 1998) ${ }^{38}$. Outro artigo de Döppenschmitt também foi publicado nos anais do XI Encontro Regional da Associação Brasileira de Literatura Comparada (ABRALIC), analisando as performances e a tradução da voz narrativa literária para a fílmica no filme Memórias do Subdesenvolvimento (Tomás Gutiérrez, 1968). Há também o artigo de Márcia Carvalho da Silva, publicado na Caligrama: Revista de Estudos e Pesquisa em Linguagem e Mídia da ECA/USP, analisando os elementos da trilha sonora como correspondentes de uma classificação do som em três categorias: nãorepresentativo, representativo e figurativo. Um artigo de Consuelo Lins sobre a questão da narração em off no cinema documentário, publicado nos anais do XVI Encontro Nacional da COMPÓS. Um artigo de Suzana Reck Miranda articulando a voz e a escuta no filme de François Girard sobre o pianista Glenn Gould (Thirty-two short films about Glenn Gould, 1993), publicado no livro do VIII Encontro da SOCINE. E mais um texto de Eduardo Santos Mendes, escrito em parceria com Ney Carrasco, discorrendo sobre a relação imagem e som nos filmes de Stanley Kubrick, e que foi publicado na revista CULT - Revista Brasileira de

38 Aqui vale uma pequena correção: no artigo consta que o filme é do ano de 1999, mas consultando o Internet Movie Database, principal base de dados de filmes na internet, o filme é datado no ano de 1998. 
Cultura, da Editora Bregantini.

Em 2007 aconteceu ainda outro lançamento de catálogo de mostra de cinema que explora o som em filmes. Nesta ocasião, o Centro Cultural Banco do Brasil (CCBB) realizara entre os dias 4 e 22 de julho na cidade de São Paulo a mostra de cinema "E o Som se Fez", com curadoria de Fernando Morais da Costa. Embora não estando aqui também contabilizado e analisado, o catálogo trás consigo o texto de abertura "O som, desde o início do cinema" de COSTA, prosseguido de quinze análises - uma para cada filme exibido na mostra - voltadas para a sofisticação da trilha sonora das obras presentes. Colaboraram para tal, os pesquisadores Hernani Heffner, Suzana Reck Miranda, Fabián Nuñez, Rafael de Luna Freire e Luís Alberto Rocha Melo.

No ano de 2008 a pesquisa brasileira contemporânea sobre o som no cinema continua prosperando, totalizando treze trabalhos. A começar pelo lançamento do segundo livro nacional da área, "O Som no Cinema Brasileiro" de Fernando Morais da Costa, publicado pela editora 7Letras. O livro é proveniente da tese de doutorado do autor defendida em 2006 e propõe rever um paradigma sobre o cinema no Brasil que havia se tornado senso comum e que dizia que "o som é o que há de pior tecnicamente nos filmes nacionais". A partir de quatro períodos estipulados, os quais envolvem desde o ano de 1902 até o início dos anos 2000, a história e a importância do som no cinema brasileiro é reconhecida.

Além do livro, o número de dissertações cresce para três. A preocupação em desvendar aspectos da história do som no cinema nacional continua através do trabalho de mestrado de Tide Borges Guimarães denominado “A Introdução do Som Direto no Cinema Documentário Brasileiro na Década de 1960", e que foi defendido no Programa de Pós-Graduação em Ciências da Comunicação da USP. Como o título já sugere, o trabalho foca na introdução da técnica de gravação de som sincrônico com equipamento leve no cinema documentário do país. As outras duas dissertações são: "Entre a escuta e a visão: o lugar do espectador na obra de Robert Bresson” de Pedro Cardoso Aspahan, defendida no Programa de Pós-Graduação em Comunicação Social da UFMG, e que analisa a relação entre a escritura fílmica e o lugar do espectador na obra de Robert Bresson. E "O Compositor Stanley Kubrick: análise do som do filme De olhos bem fechados de Stanley Kubrick através da teoria sonora de Michel Chion" de Márcio Cardoso Marcolino, defendida no Programa de Pós-Graduação em Artes Visuais também da UFMG, e que analisa a articulação audiovisual do filme De olhos bem fechados (Stanley Kubrick, 1999), destacando o potencial do som nas escolhas narrativas do diretor.

A quantidade de artigos também cresce, subindo para nove. Dois deles foram publicados na Revista Universitária Audiovisual (RUA) da Universidade de São Carlos (UFSCar): um de 
José Eduardo Bozicanin discorrendo sobre a trilha sonora do filme Akira (Katsuhiro Ôtomo, 1988); e um de Gerson Rios Leme, sobre a criação sonora audiovisual. Outros dois são de autoria de José Cláudio Castanheira. Um propondo investigar o ambiente sonoro e as formas de cognição beneficiadas com o uso de sons criados ou modificados eletronicamente, e outro sobre a participação do som eletrônico na construção da impressão de realidade no cinema. Ambos foram publicados na revista Contemporânea do grupo de pesquisa "Comunicação, Arte e Cidade" da Faculdade de Comunicação Social da Universidade do Estado do Rio de Janeiro (UERJ). Há também um artigo de Elen Döppenschmitt sobre a política da voz no longa-metragem Memórias do Subdesenvolvimento (Tomás Gutiérrez Alea, 1968), publicado na revista Devires - Cinema e Humanidades da UFMG. Um artigo de Andre Gatti em parceria com Eduardo Santos Mendes, sobre o desenvolvimento do som no cinema, publicado na Coleção Cadernos de Pesquisa do Centro Cultural São Paulo (CCSP) intitulada O Novo Cinema Paulista. Um texto de Luciana Haussen sobre a relevância do som na história do cinema, na revista Sessões do Imaginário do Programa de Pós-Graduação em Comunicação Social da PUC-RS. Outro de Aline Riera Pedreiras sobre o sistema surround 5.1, publicado na Revista Sonora do Instituto de Artes da UNICAMP. E ainda, um artigo de Márcia Regina Carvalho da Silva analisando os elementos da trilha sonora no cinema, na Revista de Comunicação Audiovisual da INTERCOM.

Vale destacar que no ano de 2008 também houve o lançamento de mais um catálogo de mostra de cinema que explorou a fundo várias questões do som cinematográfico. Promovido pela CAIXA Cultural nas cidades do Rio de Janeiro e de São Paulo, o objetivo foi de apresentar uma história do cinema mundial a partir do som. Apesar de estar aqui mencionado, mas não contabilizado nem investigado, este catálogo pode ser considerado o mais completo até então publicado. Para aprofundar a reflexão sobre o tema, o catálogo reúne tanto textos inéditos de pesquisadores como: Fernando Morais da Costa, João Luiz Vieira, Suzana Reck Miranda, Mariana Baltar, Arnaldo Di Pace, Virginia Flores e Ivan Capeller; quanto textos de referências, como de Noel Burch, Eisenstein, Béla Balázs, Robert Bresson, Walter Murch, etc. Há ainda uma bibliografia comentada apresentada por Ivan Capeller, contendo cinco livros fundamentais sobre o som no cinema indicados por ele $^{39}$.

Depois do propulsor ano de 2008, no ano de 2009 há uma pequena redução no número total de trabalhos, caindo de treze para onze. Isso por conta de não ter havido nenhuma defesa

39 São eles: La Voix au Cinéma (1982) e Un Art Sonore: le cinéma, histoire, esthétique, poétique (2003) ambos de Michel Chion; Film Sound: theory and Practice (1985) de Elisabeth Weis e John Belton; Une Archéologie du Cinéma Sonore (2004) de Giusy Pisano; e Analyse et Réception des Sons au Cinéma (2007) de Thierry Millet. 
de tese, nem lançamento de livro. O número de artigos diminuiu para oito unidades, e a quantidade de dissertações seguiu na média do ano anterior, com três publicações.

As três dissertações defendidas em 2009 foram: a de Ana Luiza Barbosa, denominada “A relação som-imagem nos filmes de animação norte- americanos no final da década de 1920: do silencioso ao sonoro", defendida no Programa de Pós-Graduação em Ciências da Comunicação da USP, e que discute sobre a função do som no cinema de animação norteamericano. A de Débora Opolski, nomeada "Análise do design sonoro no longa-metragem Ensaio Sobre a Cegueira", defendida no Programa de Pós-Graduação em Música da UFPR, e que foca no processo de pós-produção do som do filme Ensaio Sobre a Cegueira (Fernando Meirelles, 2008). E a de Andreson Carvalho, defendida no Programa de Pós-Graduação em Comunicação da UFF. Denominada "A Percepção Sonora no Cinema: ver com os ouvidos, ouvir com outros sentidos", pesquisa a percepção e o espaço sonoro no cinema.

Parte da dissertação de Débora Opolski foi publicada nesse mesmo ano em formato de artigo nos anais do V Encontro de Música e Mídia (MusiMid), vinculado ao Departamento de Música da ECA/USP, focando na composição dos sons ambientes do mesmo filme estudado, Ensaio Sobre a Cegueira. Outros dois artigos foram escritos por Kira Pereira, e publicados na Revista Universitária Audiovisual (RUA). Um discutindo a relação imagem e som do médiametragem Candinho (1976) de Ozualdo Candeias, e outro divulgando resultados parciais do mestrado da autora que ainda estava em andamento, discorrendo sobre a origem do processo de criação do som no filme Ensaio Sobre a Cegueira. A RUA também recebeu o artigo de Alfredo Torres sobre a trilha sonora do filme Os Pássaros (Alfred Hitchcock, 1963). Dois outros textos são de autoria de José Cláudio Castanheira. Um publicado na revista Entre.Meios, associada à Pós-Graduação em Comunicação Social da PUC-Rio, discorrendo sobre a construção dos códigos narrativos do cinema e sua relação com a prática sonora e os modelos de audibilidades dos primeiros cinemas. E outro na revista Contemporânea sobre a importância do som na sensibilização do corpo imerso no dispositivo cinematográfico. Há ainda um artigo escrito por Natalia Barrenha em parceria com Antônio Fernando Passos sobre a utilização do som off na obra da cineasta argentina Lucrecia Martel, publicado nos anais da INTERCOM. E também, um de Fabiana Quintana sobre a importância da trilha sonora no filme Orfeu (Cacá Diegues, 1999).

Apesar da pequena redução no número total de trabalhos no ano de 2009, vale destacar que é neste mesmo ano que surge o seminário temático da SOCINE voltado diretamente para os estudos do som no cinema e no audiovisual. Este seminário, singular no país, desde então vem obtendo êxito, recebendo um grande número de propostas de comunicações ao longo dos 
anos, e auxiliando na integração da pesquisa e dos pesquisadores brasileiros do som cinematográfico.

Quando comentamos sobre o êxito deste seminário nos últimos anos, isto significa dizer que a partir das mesas pré-constituídas nos encontros da SOCINE até 2008 criou-se um encontro onde nomes conhecidos por estudar costumeiramente a trilha sonora dos filmes no Brasil puderam dialogar com pesquisadores novos e com uma platéia sempre em bom número. Às doze comunicações apresentadas no primeiro encontro seguiram-se dezoito no segundo, e quinze no terceiro. Tal diminuição, entretanto, não se deveu a uma possível redução do encaminhamento de propostas. Pelo contrário, no ano de 2011 o seminário recebeu a maior quantidade de trabalhos propostos, embora os coordenadores tenham decidido reservar um dos seis horários para discussão interna, fruto também do amadurecimento do trabalho. Nos três encontros [2009, 2010 e 2011], o seminário congregou pesquisadores da USP, da UNICAMP, da UFSCar, da UFF, da UFRJ, da UFJF, da UFSC, da UFRB, da UFBA, da UFPE, bem como participantes das universidades de Salamanca e de Bochum, o que traduz, ao mesmo tempo, a efetivação de um diálogo em âmbito nacional e o contato profícuo com instituições internacionais. ${ }^{40}$

Em 2010 o número de artigos mantem-se o mesmo em relação ao ano de 2009, bem como a quantidade de dissertações. A novidade é o surgimento de duas teses defendidas, o que faz com que o número total de trabalhos volte a atingir a marca de 2008, com o total de treze trabalhos. Tem-se então a tese de Daniel Werneck sobre o som no cinema de animação, intitulada "Movimentos Invisíveis: história da estética do som do cinema de animação", e defendida no Programa de Pós-Graduação em Artes da UFMG. E a tese de Elen Döppenschmitt, "Por uma Política da Voz no Cinema: estratégias para emancipação do espectador em Memórias do Subdesenvolvimento de Tomás Gutiérrez”, reunindo informações publicadas nos artigos da autora de 2007 e 2008, enfatizando o papel da voz no filme cubano Memórias do Subdesenvolvimento (Tomás Gutiérrez Alea, 1968), dentre outros aprofundamentos diante o caráter revolucionário da obra.

Já as três dissertações presentes no ano de 2010 são: "Se Podes Ouvir, Escuta: a gênese audiovisual de Ensaio Sobre a Cegueira", de Kira Pereira, defendida no Programa de PósGraduação em Ciências da Comunicação da USP, e que disserta sobre o processo de criação audiovisual, com ênfase na construção sonora do filme Ensaio Sobre a Cegueira (Fernando Meirelles, 2008). “A Paisagem Sonora Eletrônica: a construção de novas audibilidades no cinema" de José Cláudio Castanheira, defendida no Programa de Pós-Graduação em Comunicação Social da UERJ, e que propõe uma complexa abordagem sobre novos modelos perceptivos no cinema a partir de conceitos da fenomenologia, das ciências cognitivas e da teoria das materialidades. E "Expressividade oral no cinema: diálogos com a fonoaudiologia"

40 Informação retirada do site da SOCINE. Disponível em: <http://socine.org.br/encontro/semi_publicacao.asp? cod=61>. Acesso em 26 março de 2013. 
de Priscila Haydée Souza, defendida no Programa de Pós-Graduação em Fonoaudiologia da PUC-SP, e que, como pode ser notado pelo título, analisa a questão da expressividade oral no cinema a partir de entrevistas com profissionais do meio.

Sobre os oito artigos presentes nesse ano, dois deles foram escritos em conjunto por Vitoria Rocha Amaral, Léslie Ferreira e Priscila Haydée Souza. O primeiro, contando também com a participação de Maria Laura Martz, foi publicado na revista Galáxia do Programa de Pós-Graduação em Comunicação e Semiótica da PUC-SP e discorre sobre o papel interpretativo dos recursos da voz e da fala no filme Cidade de Deus (Fernando Meirelles e Kátia Lund, 2002). E o segundo, publicado na revista Distúrbios da Comunicação do Programa de Pós-Graduação em Fonoaudiologia também da PUC-SP, sobre o trabalho desenvolvido com a voz e a fala no cinema, com ênfase na atuação fonoaudiológica. Outros dois artigos são de autoria de Rodrigo Carreiro. Um publicado no livro do XIII Encontro da SOCINE e outro na revista E-compós da Associação Nacional dos Programas de PósGraduação em Comunicação (COMPÓS). Ambos possuem o conteúdo idêntico e falam do uso do som no longa-metragem Cinema, aspirinas e urubus (Marcelo Gomes, 2005). Outros dois textos são de Fernando Morais da Costa. Um sobre os ruídos como matéria-prima para a produção cinematográfica contemporânea, publicado na revista Logos: Comunicação \& Universidade ligada ao Programa de Pós-Graduação em Comunicação da UERJ; e outro analisando o som dentro do plano-sequência no cinema, também publicado no livro do XIII Encontro da SOCINE. Há ainda o artigo de José Cláudio Castanheira, proveniente de sua dissertação, publicado na revista Contemporânea, estudando o som eletrônico no cinema por um viés fenomenológico. E mais o artigo de Fabiana Quintana sobre a trilha sonora no filme Blue (Derek Jarman, 1993), publicado nos anais do VI Encontro de Música e Mídia (MusiMid).

Chega-se então ao ano de 2011, último investigado. Em relação à quantidade de teses e dissertações de 2010, há pouca alteração. O número de teses cai para um, ao mesmo tempo que o número de dissertações mantem-se em três. $\mathrm{O}$ grande destaque está na quantidade de artigos que atinge uma marca recorde dentro do período avaliado. Foram dezenove artigos publicados, e que fazem de 2011 o ano de maior produção da pesquisa brasileira contemporânea sobre o som no cinema aqui estudada.

A única tese deste ano é o trabalho de doutorado de João Godoy, defendido no Programa de Pós-Graduação em Ciências da Comunicação da USP. Intitulado "Procedimentos de trabalho na captação de som direto nos longas-metragens brasileiros Contra todos e Antônia: a técnica e o espaço criativo", consiste em uma minuciosa reflexão sobre a prática de trabalho 
do registro sonoro sincrônico no cinema, e se torna o mais completo material sobre o som direto em língua portuguesa publicado até o momento. Já no campo das dissertações, tem-se a de Natalia Barrenha abordando a obra, a trajetória, as opções estéticas e o processo criativo da cineasta Lucrecia Martel. Nomeada "A experiência do cinema de Lucrecia Martel: resíduos do tempo e sons à beira da piscina", foi defendida no Programa de Pós-Graduação em Multimeios da UNICAMP. A dissertação intitulada "Criando Mundo com Sons: pós-produção de som e sound design no cinema" de Mauricio de Caro Esposito, que discute o processo de pós-produção de som no cinema e foi defendido no Programa de Pós-Graduação em Comunicação da Universidade Anhembi Morumbi. E o mestrado de Frederico Augusto Pessoa defendido no Programa de Pós-Produção em Artes da UFMG. Denominado "O Lugar Fora do Lugar: topografias sonoras do cinema documentário", a pesquisa aborda o som no cinema documentário.

Em relação aos artigos encontrados no ano de 2011, destaca-se o lançamento da revista Ciberlegenda, vinculada ao Programa de Pós-Graduação em Comunicação da UFF, e sua edição "Sonoridades", dedicada ao debate em torno do tema mídia e sonoridades. Composta por dois volumes, um apresentando discussões sobre o som nas produções audiovisuais modernas e contemporâneas, e outro sobre novas tecnologias e estéticas sonoras midiáticas, a revista ainda disponibiliza mais materiais em seu espaço online denominado "Estação Transmídia”, onde é possível encontrar, por exemplo, uma entrevista realizada com o pesquisador e compositor francês Michel Chion $^{41}$. Da diversidade de artigos presentes na revista, dez enquadram-se no recorte proposto por essa revisão sistemática. Destes dez, dois são de autoria de Fernando Morais da Costa: um questionando se há um hiper-realismo sonoro no cinema argentino contemporâneo, e outro sobre o uso do silêncio no cinema. Um de Luiza Alvim sobre as paisagens sonoras na obra de Robert Bresson; um de Mauricio Caleiro sobre as abordagens sonoras empregadas no filme O Silêncio (Mohsen Makhmalbaf, 1998); um de Ivan Capeller sobre a arqueologia da escuta; um de Rodrigo Carreiro sobre o som no cinema de horror; um de Rafael de Luna Freire sobre a história da dublagem cinematográfica no Brasil; um de Isaac Pipano sobre as paisagens sonoras no documentário Dong (Jia Zhang-ke, 2006); um de Viviane Vedana sobre a montagem de documentários etnográficos sob a perspectiva da banda sonora; e um de Rafael Venancio sobre os efeitos sonoros nos curtas-metragens de animação estrelados pela personagem Gerald McBoingBoing.

${ }^{41}$ SACIC, Rodrigo Maia. "A pista sonora não existe": entrevista com Michel Chion. Ciberlegenda (UFF. Online), 2011. Disponível em: <http://www.proppi.uff.br/ciberlegenda/\%E2\%80\%9C-pista-sonora-n $\%$ C3\%A3o-existe\%E2\%80\%9D>. Acesso em 30 jul. 2011. 
Além desses artigos da Ciberlegenda, outros nove foram contabilizados em 2011. Dois de José Cláudio Castanheira, sendo um sobre novos modelos de escuta no cinema, publicado na Revista de Estudos da Comunicação do curso de Comunicação Social da PUC-PR; e outro discutindo a contribuição da perspectiva dos Sound Studies à análise do som no cinema, publicado no livro do XIV Encontro da SOCINE. Neste mesmo livro da SOCINE também foi publicado o artigo de Rodrigo Carreiro sobre o uso do som na obra do cineasta italiano Sergio Leone.

Há também o texto de Natasha Almeida sobre a construção do espaço sonoro no curtametragem O Artista (Luiz Carlos Ribeiro Borges, 1967), publicado na revista CoMtempo do Programa de Pós-Graduação em Comunicação da Faculdade Cásper Líbero. O artigo de Bernardo Marquez Alves sobre a produção sonora no cinema contemporâneo e o processo de finalização do som do filme Tropa de Elite 2 (José Padilha, 2010), publicado na revista Cinema Caipira do Grupo de Cinema Kino-Olho. O de Damyler Cunha discutindo a utilização do ruído fora-de-campo como força expressiva cênica, publicado na revista Rumores do Grupo de Estudos de Linguagem e Práticas Midiáticas da ECA/USP. O texto de Gerson Leme sobre classificações dos elementos da trilha sonora cinematográfica, publicado na revista Orson do curso de graduação em Cinema e Audiovisual e Cinema de Animação da Universidade Federal de Pelotas. O de Rodrigo Rodrigues sobre as sonoridades do cinema de Tarkovsky e a relação entre composição musical e design sonoro no cinema, publicado na revista Mediação dos cursos de Publicidade e Propaganda e de Jornalismo da Universidade FUMEC. E por fim, mais um artigo de Fernando Morais da Costa sobre o uso do som no cinema brasileiro contemporâneo, publicado na revista Filme Cultura do Minc/CTAv (Centro Técnico Audiovisual).

Uma curiosidade do ano de 2011 é que nele houve também o lançamento da edição em língua portuguesa (de Portugal) de um dos livros mais famosos na contemporaneidade que estuda o som e a articulação audiovisual no cinema, "A Audiovisão: som e imagem no cinema" de Michel Chion. Mesmo existindo críticas sobre a qualidade dessa tradução, essa edição expande as possibilidades de contato com as teorias de um dos maiores pesquisadores da área.

Fazendo o balanço geral, tem-se um total de dois livros, cinco teses, vinte e uma dissertações, e sessenta e quatro artigos, resultando em noventa e dois trabalhos publicados entre os anos de 2001 e 2011, respeitando os limites propostos nessa revisão sistemática. O número de livros ainda é singelo, mas para uma área de estudo que não tinha nenhum específico até o fim do século XX, já é um avanço. Vale mencionar que este número segue 
crescendo, uma vez que por exemplo, no ano de 2012 houve o lançamento de dois livros: "Som+Imagem" (SÁ; COSTA, 2012) e "Políticas da Voz no Cinema em Memórias do Subdesenvolvimento" (DÖPPENSCHMITT, 2012). E em 2013 há a previsão de publicação de mais três, provenientes das dissertações de Virginia Flores, Débora Opolski e Natalia Barrenha, mas que até o fechamento dessa pesquisa, ainda estão no prelo ${ }^{42}$. O número de teses também é modesto. Interessante notar que das cinco defendidas, duas já viraram livros. A de Fernando Morais da Costa (2006) e a de Elen Döppenschmitt (2010). Portanto, observa essa disposição em aproveitar as pesquisas das teses e dissertações para a posterior publicação de livros da área. O número de dissertações é persistente, seguindo em progresso desde o ano de 2003 e se estabilizando em uma média de três trabalhos por ano a partir de 2008. Os trabalhos de mestrado podem, portanto, serem considerados os responsáveis por uma base estrutural quantitativa e evolutiva da pesquisa brasileira contemporânea sobre o som cinematográfico nesse espaço de tempo estudado. Já o número de artigos é o grande responsável pela variação dos valores totais de trabalhos produzidos no período, atingindo seu ápice ao impulsionar a quantidade de materiais publicados em 2011.

Apesar de ser apenas um levantamento numérico, essa amostragem da evolução quantitativa da pesquisa brasileira contemporânea sobre o som cinematográfico demonstra que até então, o campo dos estudos do som no cinema esteve em um considerável desenvolvimento no país, principalmente a partir da metade da primeira década do século XXI.

\subsection{Tendências Temáticas}

Após este levantamento quantitativo da pesquisa brasileira contemporânea sobre o som no cinema dos anos 2001 à 2011, presencia-se uma diversidade de maneiras com que a trilha sonora foi até então investigada. Logo, a intenção é de identificar os principais assuntos tratados, organizar e classificar esses materiais em grupos para averiguar suas possíveis tendências temáticas.

$\mathrm{Na}$ busca por organizar e classificar essa bibliografia em tópicos específicos, foram estudadas propostas relevantes de catalogação que procuraram ao longo dos anos realizar algum tipo de mapeamento semelhante a nível do exterior. Bibliography on Sound in Film

42 O livro de Virgínia Flores será lançado com o mesmo título “O Cinema: uma arte sonora”, pela Editora Annablume. O de Débora Opolski com o título "Introdução ao Desenho de Som: uma sistematização aplicada na análise do longa-metragem Ensaio Sobre a Cegueira", pela Editora Universidade UFPR. E o de Natalia Barrenha também com o mesmo título da dissertação, "A experiência do cinema de Lucrecia Martel: resíduos do tempo e sons à beira da piscina”, pela editora Alameda Editorial. 
(GORBMAN, 1980) foi o primeiro levantamento bibliográfico descritivo relacionado ao universo da trilha sonora cinematográfica que reuniu praticamente todos os livros e artigos publicadas em língua inglesa e francesa até o final da década de 1970. Contendo cerca de 330 títulos, a bibliografia foi dividida em três seções: I. Teoria geral e estética; II. Tecnologia (subdividida em “A. Geral” e "B. História - a chegada do som”); e III. Música ${ }^{43}$. Cinco anos depois, GORBMAN revisa este levantamento e o publica novamente, desta vez com breves comentários em cada bibliografia referida. Em Annotated Bibliography (GORBMAN, 1985) as categorias haviam mudado. A seção sobre "Música" foi excluída e apenas as de "Teoria geral e estética" e de "Tecnologia em geral" foram mantidas. Nesse caso os materiais foram então divididos nas seguintes seções: I. Teoria geral e estética; II. Análise e estudo de caso; III. Tecnologia em geral; e IV. História: estilo e tecnologia ${ }^{44}$. Sem diminuir o mérito e o pioneirismo de GORBMAN, e apesar dessas classificações não serem consideradas mutuamente exclusivas, em nenhuma das duas situações a autora justificou a escolha dos tópicos, ou apresentou os métodos utilizados para tal. Ela apenas informou o que o leitor iria encontrar em cada seção, como a exemplo na segunda publicação:

Ensaios de categorias mistas que abordam a prática do som de filme em contextos teóricos [...] estão localizados na seção de Teoria Geral e Estética; ensaios cuja ênfase na técnica ou pragmática superam seu interesse teórico, estão na seção III. Artigos escritos durante o período do início do som no cinema não estão listados em História, mas em Estética (I) ou Tecnologia (III), dependendo da ênfase. Eu geralmente coloquei entrevistas com diretores de filmes específicos na seção II, e entrevistas com técnicos, tal como engenheiros de som, na seção III. O leitor encontrará nas seções III e IV bibliografias mais seletivas, por necessidade, que nas seções I e II. Do mesmo modo, eu objetivei dar apenas uma amostra de artigos típicos e/ou teoricamente interessantes do período da chegada do som. A bibliografia exclui artigos que traçam analogias entre filmes visuais e som a fim de examinar ideias como ritmo visual, "overtones" (Eisenstein e Sharits), e outras do tipo. Eu também não inclui geralmente (com exceção de Brakhage) ensaios preocupados principalmente com alusões ao som em filmes mudos. ${ }^{45}$ (GORBMAN, 1985: 427)

Já na Bibliographie Sur le Son au Cinéma et Dans les Autres Arts (LAVOIE, s. d.), que contém mais de 800 materiais relacionados e se auto considera um dos mais abrangentes levantamentos já montado sobre o som e a música no cinema e em outras artes, divide sua bibliografia em nove assuntos: I. Criadores: depoimentos, entrevistas e análises; II. Análise do som de uma obra ou filme; III. Teoria, estética e poética do som no cinema; IV. Música de filme; V. A voz no cinema; VI. Do mudo ao falado; VII. Arte sonora; VIII. História, sociologia

43 Do original: I. General theory and Aesthetics; II. Technology (A. General; B. History - the coming of sound); III. Music (GORBMAN, 1980: 269).

44 Do original: I. General Theory and Aesthetics; II. Analyses and Case Studies; III. General Technology; IV. History: Style and Technology (GORBMAN, 1985: 427).

45 Tradução do autor. 
e filosofia do som; e IX. Trabalhos, ferramentas e técnicas de criação ${ }^{46}$. O autor também não justifica nem apresenta os métodos utilizados na escolha dos tópicos.

Ainda nesta linha para identificar tendências importantes na literatura sobre a trilha sonora cinematográfica, em The Trail of Snail: Recent Literature on Sound Design (WEIS, 1999), artigo contendo também uma revisão bibliográfica comentada, foram apontados outros tipos de abordagens comuns de serem reveladas nos materiais escritos sobre o som no cinema. Para WEIS, que fez o levantamento de trabalhos publicados apenas na década de 1990, escrever sobre sound design no cinema tendia na época a cair em cinco tipos de aproximações:

\begin{abstract}
A maioria dos artigos são estudos de caso que focam em problemas sonoros e ad hoc soluções técnicas de filmes atuais (geralmente de alto orçamento). A segunda categoria compreende artigos de ou sobre proeminentes profissionais da indústria. Nesse grupo inclui perfis e histórias orais, mas por serem ocasionadas frequentemente pelo laçamento de filmes recentes, acabam caindo na categoria de estudo de caso. Nessa circunstância, se concentram no trabalho mais recente de um profissional. Um terceiro gênero é escrito por um conjunto de autores, a maioria sound designers profissionais que possuem uma vocação para fazer a arte do sound design ser apreciada e compreendida. Em quarto, embora um tipo raro, é a abordagem didática a descrição do processo em si que, por ser escrita por especialistas no assunto que valorizam a arte do som, pode ter um tom de defesa. De qualquer maneira, esses autores assumem que o conhecimento do processo é uma informação saudável para diretores e outros do mercado, para acadêmicos e para estudantes de cinema. Em quinto tem os ensaios teóricos em som que discutem sound design diretamente ou por implicação. ${ }^{47}$ (WEIS, 1999: 95)
\end{abstract}

Ao organizar esses cinco tipos comuns de aproximação das escrituras, WEIS acaba por mesclar tópicos mais evidentes de abordagens - como por exemplo: "estudos de casos", "perfis e histórias orais", "ensaios teóricos" e "abordagem didática" - com características e particularidades de autoria de cada grupo de trabalho. Os critérios de organização dessas aproximações não são evidentes, mas percebe-se que provém das estimativas constatadas e reforçadas durante a exposição dos conteúdos de cada material mencionado por ela no decorrer do texto. Vale ressalvar que para comentar a bibliografia revisada ao longo do artigo, a autora agrupa os materiais de acordo com o formato de publicação, e não pelas cinco categorias apresentadas. Ou seja, ela agrega os documentos nos itens: "Três Antologias"; "Artigos"; "Edições Especiais de Periódicos de Cinema"; e "Revistas Especializadas e Websites" ${ }^{48}$. Ao final do texto WEIS ainda aponta novas diretrizes e a cena internacional das

46 Do original: I. Les créateurs: témoignages, entretiens, analyses; II. Analyses du son dans une œuvre ou un film; III. Théorie, esthétique et poétique du son au cinéma; IV. Musique de film; V. La voix au cinéma; VI. Du muet au parlant; VII. Art du son; VIII. Histoire, sociologie et philosophie du Son; e IX. Métiers, outils et techniques de création.

47 Tradução do autor.

48 Do original: Three Anthologies; Articles; Special Issues of Film Periodicals; Specialty Journals and Websites. 
pesquisas sobre o som no cinema, sugerindo também conteúdos a serem desenvolvidos no futuro.

Uma intenção correspondente encontra-se no item Trends in Literature on the Film Soundtrack da pesquisa de doutorado de McGILL (2008), que também combina tópicos mais claros de abordagens com características e particularidades da autoria dos trabalhos. Para McGILL (2008: 16), são quatro as instâncias fundamentais da literatura sobre a trilha sonora no cinema, podendo haver sobreposições entre as categorias e variações no grau de ênfase na autenticidade de cada material como objeto crítico ou local de prática de produção. Apesar de não ser a proposta da tese organizar, nem trabalhar sobre essas instâncias, McGILL declara:

Em primeiro lugar há trabalhos acadêmicos que abordam a trilha sonora a partir de perspectivas teóricas - que vão de estudos de gênero e psicanálise [...] a análises formais $[\ldots]$ e musicologia. Em segundo lugar há documentos escritos por estudiosos de cinema que se concentram em contextos da produção da trilha sonora, indo da arte e técnica dos profissionais de som até as tecnologias empregadas nos processos criativos [...]. Uma terceira tendência pode ser identifica em obras escritas pelos próprios criadores dos sons dos filmes, que frequentemente tem servido de fonte para estudiosos. Eles combinam os registros do profissionalismo - fornecendo considerações de primeira mão de práticas de criação e produção - com reflexões teóricas sobre a estética do som do filme [...]. Finalmente, há trabalhos escritos por profissionais projetados para outros profissionais, e são em geral destinados para fins de instrução técnica e artística [...]. (McGILL, 2008: 16-17)

Com base nessas referências de mapeamento aludidas, observa-se a dificuldade em encontrar padrões de categorizações dos materiais sobre som no cinema. Ora partindo de abordagens mais gerais, ora associado a assuntos estéticos, o tópico "Teoria" talvez seja o único em comum entre todas essas propostas consideradas. Não obstante, na determinação das classificações sugeridas, WEIS (1999) e McGILL (2008) realçaram brevemente o perfil dos autores e o contexto das bibliografias, sendo que WEIS acaba reunindo os materiais de acordo com o formato de publicação e McGILL se quer trabalha sobre os dados. Já GORBMAN (1980 e 1985) e LAVOIE (s. d.) se ativeram somente nas temáticas. A primeira de forma bem abrangente, e o segundo um tanto mais ousado ao discriminar tópicos diversos, porém envolvendo outras artes que não só o cinema. Sem um método de separação inicial, aparentemente Gorbman e Lavoie recolhem os trabalhos feitos em períodos determinados, observam os assuntos principais de cada material e assim os classificam. Portanto, a ausência de justificativas e metodologias concretas na elaboração dessas taxionomias leva a crer que trata-se de um julgamento particular dos autores de acordo com a avaliação dos textos presentes em cada levantamento bibliográfico.

Com o propósito de explorar as tendências de vínculo temático inerentes à pesquisa 
sobre o som cinematográfico no Brasil, e eleger categorias direcionadas que possam representar neste momento os principais tópicos julgados mais condizentes com a realidade brasileira contemporânea dos estudos do som no cinema, foram coletados - como já mencionado no capítulo sobre a metodologia dessa dissertação - os assuntos ou temas, os subtemas, os objetos e os corpus específicos de estudo dos materiais aqui investigados. Esses dados foram distribuídos de acordo com o formato, o título, o autor e o ano do trabalho como pode ser conferido na tabela a seguir:

\section{TABELA II}

Distribuição dos temas, subtemas, objetos e corpus específicos de estudo perante o formato, o título, o autor e o ano dos trabalhos:

\begin{tabular}{|c|c|c|c|c|c|}
\hline Formato & Título/Autor/Ano & Tema/Assunto & Subtemas & Objetos & Corpus \\
\hline Livro & $\begin{array}{l}\text { O Som no Cinema } \\
\text { Brasileiro / Fernando } \\
\text { Morais da Costa / } 2008 .\end{array}$ & $\begin{array}{l}\text { O som no cinema } \\
\text { brasileiro. }\end{array}$ & $\begin{array}{l}\text { - História do som no } \\
\text { cinema brasileiro. }\end{array}$ & $\begin{array}{l}\text { - O cinema brasileiro; } \\
\text { - Tecnologia do som no } \\
\text { cinema. }\end{array}$ & $\begin{array}{l}\text { - Primeiras tentativas de sincronização, } \\
\text { entre } 1902 \text { e 1911; } \\
\text { - A transição para o cinema sonoro no fim } \\
\text { da década de } 1920 \text { e meados de } 1930 ; \\
\text { - As mudanças relacionadas com a chegada } \\
\text { dos primeiros gravadores de som portátil, } \\
\text { lideradas principalmente pelo Nagra em } \\
\text { 1962; } \\
\text { - A dicotomia entre a excelência técnica } \\
\text { alcançada e a evolução da estética sonora } \\
\text { dos filmes a partir dos anos } 1990 \text {. }\end{array}$ \\
\hline Livro & $\begin{array}{l}\text { Som-imagem no cinema: } \\
\text { a experiência alemã de } \\
\text { Fritz Lang / Luiz Adelmo } \\
\text { Manzano / } 2003 \text {. }\end{array}$ & $\begin{array}{l}\text { A função do som no } \\
\text { cinema. }\end{array}$ & $\begin{array}{l}\text { - A experiência alemã de } \\
\text { Fritz Lang; } \\
\text { - O som na narrativa } \\
\text { fílmica; } \\
\text { - Teorias de cinema e } \\
\text { suas relações com o som } \\
\text { dos primórdios do } \\
\text { cinema até o advento do } \\
\text { som. }\end{array}$ & $\begin{array}{l}\text { - O cinema mudo; } \\
\text { - O cinema sonoro; } \\
\text { - O cinema } \\
\text { expressionista alemão. }\end{array}$ & $\begin{array}{l}\text { - Contexto histórico e o processo de } \\
\text { evolução do cinema expressionista alemão } \\
\text { (dos primórdios até 1931); } \\
\text { - Os filmes de Fritz Lang: Metropolis } \\
\text { (1925-1926) e M, o Vampiro de Düsseldorf } \\
\text { (1931). }\end{array}$ \\
\hline Tese & $\begin{array}{l}\text { Movimentos Invisíveis: a } \\
\text { estética sonora do cinema } \\
\text { de animação / Daniel Leal } \\
\text { Werneck / } 2010 .\end{array}$ & $\begin{array}{l}\text { A estética sonora do } \\
\text { cinema de animação }\end{array}$ & $\begin{array}{l}\text { - História da criação do } \\
\text { som gravado; } \\
\text { - História do som no } \\
\text { cinema; } \\
\text { - Desenvolvimento do } \\
\text { som como linguagem no } \\
\text { cinema de animação; } \\
\text { - Tipos de som no filme } \\
\text { animado. }\end{array}$ & $\begin{array}{l}\text { - O cinema de } \\
\text { animação; } \\
\text { - O cinema norte- } \\
\text { americano; } \\
\text { - Tecnologia do som no } \\
\text { cinema. }\end{array}$ & $\begin{array}{l}\text { - As obras dos animadores Oskar } \\
\text { Fischinger, Len Lye e Norman McLaren. }\end{array}$ \\
\hline Tese & $\begin{array}{l}\text { O Som no Cinema } \\
\text { Brasileiro: revisão de uma } \\
\text { importância indeferida / } \\
\text { Fernando Morais da } \\
\text { Costa / 2006a. }\end{array}$ & $\begin{array}{l}\text { O som no cinema } \\
\text { brasileiro. }\end{array}$ & $\begin{array}{l}\text { - História do som no } \\
\text { cinema brasileiro. }\end{array}$ & $\begin{array}{l}\text { - O cinema brasileiro; } \\
\text { - Tecnologia do som no } \\
\text { cinema. }\end{array}$ & $\begin{array}{l}\text { - Primeiras tentativas de sincronização, } \\
\text { entre } 1902 \text { e 1911; } \\
\text { - A transição para o cinema sonoro no fim } \\
\text { da década de } 1920 \text { e meados de } 1930 ; \\
\text { - As mudanças relacionadas com a chegada } \\
\text { dos primeiros gravadores de som portátil, } \\
\text { lideradas principalmente pelo Nagra em } \\
\text { 1962; } \\
\text { - A dicotomia entre a excelência técnica } \\
\text { alcançada e a evolução da estética sonora } \\
\text { dos filmes a partir dos anos } 1990 .\end{array}$ \\
\hline
\end{tabular}




\begin{tabular}{|c|c|c|c|c|c|}
\hline Tese & $\begin{array}{l}\text { O Som no Cinema: da } \\
\text { edição de som ao sound } \\
\text { design - evolução } \\
\text { tecnológica e produção } \\
\text { brasileira / Luiz Adelmo } \\
\text { Manzano / } 2005 \text {. }\end{array}$ & $\begin{array}{l}\text { O desenvolvimento } \\
\text { do som no cinema. }\end{array}$ & $\begin{array}{l}\text { - Edição de som e sound } \\
\text { design; } \\
\text { - Evolução tecnológica } \\
\text { do som no cinema; } \\
\text { - O som no cinema } \\
\text { brasileiro. }\end{array}$ & $\begin{array}{l}\text { - Tecnologia do som no } \\
\text { cinema; } \\
\text { - Os profissionais e os } \\
\text { processos de trabalho } \\
\text { com o som no cinema; } \\
\text { - O cinema brasileiro; } \\
\text { - O cinema norte- } \\
\text { americano. }\end{array}$ & $\begin{array}{l}\text { - Evolução do uso do som no cinema desde } \\
\text { seu advento no final da década de } 1920 ; \\
\text { - Desenvolvimento tecnológico e a } \\
\text { modificação na maneira da construção } \\
\text { fílmica nos anos 1970; } \\
\text { - A pós-produção de som em Los Angeles } \\
\text { e São Francisco; } \\
\text { - Evolução do som no cinema brasileiro até } \\
\text { meados da década de 2000; } \\
\text { - Debate: “A concepção sonora no cinema } \\
\text { nos anos } 1990 \text { até o presente" realizado no } \\
\text { dia 24/11/2003; } \\
\text { - Experiência de trabalho com o cineasta } \\
\text { Joel Yamaji desenvolvida ao longo dos } \\
\text { filmes de curta-metragem nos anos } 1990 ; \\
\text { - Entrevista com os profissionais: José } \\
\text { Luiz Sasso, Mauro Alice, Virginia Flores, } \\
\text { Roberto Ferraz, Michel Ruman, Giba Assis } \\
\text { Brasil, Eduardo Santos Mendes e Miriam } \\
\text { Biderman. }\end{array}$ \\
\hline Tese & $\begin{array}{l}\text { Por uma Política da Voz } \\
\text { no Cinema: estratégias } \\
\text { para emancipação do } \\
\text { espectador em "Memórias } \\
\text { do Subdesenvolvimento" } \\
\text { de Tomás Gutiérrez / Elen } \\
\text { Döppenschmitt / } 2010 .\end{array}$ & $\begin{array}{l}\text { As estratégias para } \\
\text { emancipação do } \\
\text { espectador em } \\
\text { Memórias do } \\
\text { Subdesenvolvimento } \\
\text { (Tomás Gutiérrez } \\
\text { Alea, 1968). }\end{array}$ & $\begin{array}{l}\text { - A política da voz no } \\
\text { cinema; } \\
\text { - O caráter } \\
\text { revolucionário do filme } \\
\text { Memórias do } \\
\text { Subdesenvolvimento; } \\
\text { - Teorias sobre a voz no } \\
\text { cinema; } \\
\text { - Teorias da oralidade. }\end{array}$ & $\begin{array}{l}\text { - O cinema cubano; } \\
\text { - A voz no cinema; } \\
\text { - Oralidade e } \\
\text { performance. }\end{array}$ & $\begin{array}{l}\text { - O filme Memórias do } \\
\text { Subdesenvolvimento (Tomás Gutiérrez } \\
\text { Alea, 1968); } \\
\text { - O livro Memórias do } \\
\text { Subdesenvolvimento (Edmundo Desnoes, } \\
\text { 1965); }\end{array}$ \\
\hline Tese & $\begin{array}{l}\text { Procedimentos de } \\
\text { trabalho na captação de } \\
\text { som direto nos longas- } \\
\text { metragens brasileiros } \\
\text { Contra Todos e Antônia: a } \\
\text { técnica e o espaço } \\
\text { criativo / João Godoy de } \\
\text { Souza / } 2011 \text {. }\end{array}$ & $\begin{array}{l}\text { A prática de trabalho } \\
\text { na captação de som } \\
\text { direto. }\end{array}$ & $\begin{array}{l}\text { - Procedimentos de } \\
\text { trabalho na captação de } \\
\text { som direto no contexto } \\
\text { da produção } \\
\text { cinematográfica } \\
\text { ficcional; } \\
\text { - A incorporação do som } \\
\text { no sistema de } \\
\text { representação do cinema } \\
\text { clássico norte- } \\
\text { americano; } \\
\text { - As transformações das } \\
\text { práticas de produção e o } \\
\text { desenvolvimento de } \\
\text { tecnologia específica } \\
\text { para as necessidades da } \\
\text { realização } \\
\text { cinematográfica com } \\
\text { som direto na transição } \\
\text { para o cinema sonoro. }\end{array}$ & $\begin{array}{l}\text { - O som direto no } \\
\text { cinema; } \\
\text { - O técnico de som } \\
\text { direto; } \\
\text { - Tecnologia do som no } \\
\text { cinema; } \\
\text { - O cinema norte- } \\
\text { americano; } \\
\text { - Processo de criação. }\end{array}$ & $\begin{array}{l}\text { - A captação de som direto nos longas- } \\
\text { metragens brasileiros Contra Todos } \\
\text { (Roberto Moreira, 2004) e Antônia (Tata } \\
\text { Amaral, 2006). }\end{array}$ \\
\hline Dissertação & $\begin{array}{l}\text { Análise do design sonoro } \\
\text { no longa-metragem } \\
\text { Ensaio Sobre a Cegueira / } \\
\text { Débora Opolski / 2009a. }\end{array}$ & $\begin{array}{l}\text { O processo de pós- } \\
\text { produção de som no } \\
\text { cinema. }\end{array}$ & $\begin{array}{l}\text { - Os profissionais, as } \\
\text { principais funções e os } \\
\text { procedimentos } \\
\text { realizados no processo } \\
\text { de pós-produção de som } \\
\text { no cinema. }\end{array}$ & $\begin{array}{l}\text { - A pós-produção de } \\
\text { som no cinema; } \\
\text { - A edição de som; } \\
\text { - O design sonoro no } \\
\text { longa-metragem Ensaio } \\
\text { Sobre a Cegueira } \\
\text { (Fernando Meirelles, } \\
\text { 2008); } \\
\text { - Processo de criação. }\end{array}$ & $\begin{array}{l}\text { - O filme Ensaio Sobre a Cegueira } \\
\text { (Fernando Meirelles, 2008). }\end{array}$ \\
\hline Dissertação & $\begin{array}{l}\text { Análise dos Padrões de } \\
\text { Voz no Cinema: a } \\
\text { comunicação oral humana } \\
\text { em duas versões de The } \\
\text { Nutty Professor / Luciana } \\
\text { Castro / 2001. }\end{array}$ & $\begin{array}{l}\text { Padrões de voz no } \\
\text { cinema. }\end{array}$ & $\begin{array}{l}\text { - O uso da voz e a } \\
\text { comunicação oral em } \\
\text { duas versões do filme } \\
\text { The Nutty Professor. }\end{array}$ & $\begin{array}{l}\text { - A fonoaudiologia; } \\
\text { - A voz no cinema. }\end{array}$ & $\begin{array}{l}\text { - Os filmes The Nutty Professor (Jerry } \\
\text { Lewis, 1963) e seu remake, The Nutty } \\
\text { Professor (Tom Shadyac, 1996). }\end{array}$ \\
\hline
\end{tabular}




\begin{tabular}{|c|c|c|c|c|c|}
\hline Dissertação & $\begin{array}{l}\text { A Estereofonia Digital: } \\
\text { uma abordagem sobre a } \\
\text { técnica, o padrão e a } \\
\text { linguagem sonora } \\
\text { cinematográfica norte- } \\
\text { americana no período de } \\
1991 \text { a } 2001 \text { / Mariano } \\
\text { Alvarez / } 2007 \text {. }\end{array}$ & $\begin{array}{l}\text { A estereofonia digital } \\
\text { no cinema. }\end{array}$ & $\begin{array}{l}\text { - O uso do espaço } \\
\text { sonoro através da } \\
\text { tecnologia estereofônica } \\
\text { digital; } \\
\text { - História da evolução } \\
\text { tecnológica dos sistemas } \\
\text { de reprodução sonora } \\
\text { nos cinemas; }\end{array}$ & $\begin{array}{l}\text { - Tecnologia } \\
\text { estereofônica analógica; } \\
\text { - Tecnologia } \\
\text { estereofônica digital; } \\
\text { - Espacialidade sonora } \\
\text { no cinema; } \\
\text { - Sistemas monofônicos, } \\
\text { estereofônicos e digitais; } \\
\text { - O cinema norte- } \\
\text { americano. }\end{array}$ & $\begin{array}{l}\text { - Os filmes norte-americanos de ficção que } \\
\text { tenham ganho o prêmio de melhor som } \\
\text { dado pela Academia de Arte } \\
\text { Cinematográfica e Ciência (AMPAS) no } \\
\text { período de } 1991 \text { a } 2001 \text {. }\end{array}$ \\
\hline Dissertação & $\begin{array}{l}\text { A Experiência do Cinema } \\
\text { de Lucrecia Martel: } \\
\text { resíduos do tempo e sons } \\
\text { à beira da piscina / Natalia } \\
\text { Barrenha / } 2009 .\end{array}$ & $\begin{array}{l}\text { O cinema de Lucrecia } \\
\text { Martel. }\end{array}$ & $\begin{array}{l}\text { - A trajetória, as opções } \\
\text { estéticas e o processo } \\
\text { criativo de Lucrecia } \\
\text { Martel; } \\
\text { - O som na narrativa } \\
\text { fílmica; } \\
\text { - O som na obra de } \\
\text { Lucrecia Martel. }\end{array}$ & $\begin{array}{l}\text { - O cinema argentino; } \\
\text { - A cineasta Lucrecia } \\
\text { Martel. }\end{array}$ & $\begin{array}{l}\text { - Panorama do cinema argentino desde os } \\
\text { seus primórdios até o início do século } \\
\text { XXI. } \\
\text { - O Nuevo Cine Argentino; } \\
\text { - Os filmes de Lucrecia Martel: O Pântano } \\
\text { (2001), A Menina Santa (2004) e A Mulher } \\
\text { Sem Cabeça (2008). }\end{array}$ \\
\hline Dissertação & $\begin{array}{l}\text { A Introdução do Som } \\
\text { Direto no Cinema } \\
\text { Documentário Brasileiro } \\
\text { na Década de } 1960 \text { / Tide } \\
\text { Borges Guimarães / } 2008 .\end{array}$ & $\begin{array}{l}\text { O som direto no } \\
\text { cinema documentário } \\
\text { brasileiro. }\end{array}$ & $\begin{array}{l}\text { - A introdução do som } \\
\text { direto no cinema } \\
\text { documentário brasileiro } \\
\text { na década de } 1960 .\end{array}$ & $\begin{array}{l}\text { - O som direto no } \\
\text { cinema; } \\
\text { - O cinema brasileiro; } \\
\text { - O cinema } \\
\text { documentário. }\end{array}$ & $\begin{array}{l}\text { - O contexto do cinema brasileiro entre as } \\
\text { décadas de } 1950 \text { e } 1960 \text { : Cinema Novo, } \\
\text { Cinema Verdade e o Cinema Direto; } \\
\text { - Os quatro filmes produzidos por Thomaz } \\
\text { Farkas em São Paulo entre } 1964 \text { e } 1965: \\
\text { Memória do Cangaço, Subterrâneos do } \\
\text { futebol, Viramundo, Nossa Escola de } \\
\text { Samba; } \\
\text { - Entrevista com os profissionais: Juarez } \\
\text { Dagoberto, Miguel Sagatio, Geraldo José, } \\
\text { Walter Goulart, Mário Carneiro, Arnaldo } \\
\text { Carrilho, Eduardo Escorel, Dib Lutfi, } \\
\text { Arnaldo Jabor, Luiz Carlos Saldanha, } \\
\text { Nelson Pereira dos Santos e Thomaz } \\
\text { Farkas. }\end{array}$ \\
\hline Dissertação & $\begin{array}{l}\text { A Paisagem Sonora } \\
\text { Eletrônica: a construção } \\
\text { de novas audibilidades no } \\
\text { cinema / José Cláudio } \\
\text { Castanheira / 2010a. }\end{array}$ & $\begin{array}{l}\text { Novas audibilidades } \\
\text { no cinema. }\end{array}$ & $\begin{array}{l}\text { - Novos modelos } \\
\text { perceptivos; } \\
\text { - Descrição } \\
\text { fenomenológica da } \\
\text { experiência } \\
\text { cinematográfica; } \\
\text { - Afetações físicas } \\
\text { induzidas pelo espaço } \\
\text { sonoro eletrônico; } \\
\text { - A relação dialética e } \\
\text { dialógica entre o corpo } \\
\text { do filme e o corpo do } \\
\text { espectador. }\end{array}$ & $\begin{array}{l}\text { - O som eletrônico no } \\
\text { cinema; } \\
\text { - A paisagem sonora } \\
\text { eletrônica; } \\
\text { - Tecnologia do som no } \\
\text { cinema; } \\
\text { - Modelos de escutas } \\
\text { contemporâneos; } \\
\text { - A fenomenologia; } \\
\text { - As ciências cognitivas; } \\
\text { - Estudo das } \\
\text { Materialidades. }\end{array}$ & $\begin{array}{l}\text { - A revolução eletrônica dos anos 1950, } \\
1960 \text { e 1970; } \\
\text { - O sistema Dolby; } \\
\text { - Filmes de ficção científica como Guerra } \\
\text { nas Estrelas (George Lucas, 1977). }\end{array}$ \\
\hline Dissertação & $\begin{array}{l}\text { A Percepção Sonora no } \\
\text { Cinema: ver com os } \\
\text { ouvidos, ouvir com outros } \\
\text { sentidos / Andreson } \\
\text { Carvalho / } 2009 \text {. }\end{array}$ & $\begin{array}{l}\text { A percepção e o } \\
\text { espaço sonoro no } \\
\text { cinema. }\end{array}$ & $\begin{array}{l}\text { - A percepção auditiva; } \\
\text { - O som na narrativa } \\
\text { fílmica. }\end{array}$ & $\begin{array}{l}\text { - A audição; } \\
\text { - A percepção e a escuta; } \\
\text { - O espaço sonoro; } \\
\text { - O espectador; } \\
\text { - Tecnologia do som no } \\
\text { cinema. }\end{array}$ & $\begin{array}{l}\text { - Entrevista com um grupo de cinco } \\
\text { pessoas realizada logo após uma sessão do } \\
\text { filme A Ostra e o Vento (Walter Lima Jr., } \\
\text { 1997). }\end{array}$ \\
\hline Dissertação & $\begin{array}{l}\text { A Relação Som-Imagem } \\
\text { nos Filmes de Animação } \\
\text { Norte-Americanos no } \\
\text { Final da Década de 1920: } \\
\text { do silencioso ao sonoro / } \\
\text { Ana Luiza Barbosa / } \\
2009 .\end{array}$ & $\begin{array}{l}\text { A função do som no } \\
\text { cinema de animação } \\
\text { norte-americano. }\end{array}$ & $\begin{array}{l}\text { - História do processo } \\
\text { de produção do cinema } \\
\text { de animação e do } \\
\text { processo de criação de } \\
\text { suas trilhas sonoras no } \\
\text { período final do cinema } \\
\text { silencioso e no início do } \\
\text { cinema sonoro. }\end{array}$ & $\begin{array}{l}\text { - O cinema de } \\
\text { animação; } \\
\text { - O cinema norte- } \\
\text { americano; } \\
\text { - O cinema silencioso; } \\
\text { - O cinema sonoro; } \\
\text { - O realizador Walt } \\
\text { Disney, os irmãos } \\
\text { Fleischer e a companhia } \\
\text { Warner Bros. }\end{array}$ & $\begin{array}{l}\text { - O filme Steamboat Willie (Up Iwerks, } \\
\text { 1928); } \\
\text { - Os filmes de Walt Disney: Plane Crazy } \\
\text { (1928) e The Haunted House (1929). }\end{array}$ \\
\hline
\end{tabular}




\begin{tabular}{|c|c|c|c|c|c|}
\hline Dissertação & $\begin{array}{l}\text { A Voz na Mise en Scène: o } \\
\text { filme Cidade de Deus sob } \\
\text { a escuta fonoaudiológica / } \\
\text { Vitória Amaral / } 2007 .\end{array}$ & $\begin{array}{l}\text { A relação da voz com } \\
\text { os demais elementos } \\
\text { da linguagem } \\
\text { cinematográfica e seu } \\
\text { efeito na mise en } \\
\text { scène. }\end{array}$ & $\begin{array}{l}\text { - A escuta } \\
\text { fonoaudiológica no } \\
\text { filme Cidade de Deus } \\
\text { (Fernando Meirelles e } \\
\text { Kátia Lund, 2002). }\end{array}$ & $\begin{array}{l}\text { - A fonoaudiologia; } \\
\text { - O cinema; } \\
\text { - A voz na arte; } \\
\text { - A mise en scène. }\end{array}$ & $\begin{array}{l}\text { - A escuta fonoaudiológica no filme } \\
\text { Cidade de Deus (Fernando Meirelles e } \\
\text { Kátia Lund, 2002). }\end{array}$ \\
\hline Dissertação & $\begin{array}{l}\text { Criando Mundo com } \\
\text { Sons: pós-produção de } \\
\text { som e sound design no } \\
\text { cinema / Mauricio } \\
\text { Esposito / } 2011 .\end{array}$ & $\begin{array}{l}\text { O processo de pós- } \\
\text { produção de som no } \\
\text { cinema. }\end{array}$ & $\begin{array}{l}\text { - Etapas da produção } \\
\text { sonora cinematográfica; } \\
\text { - Sound design no } \\
\text { cinema; } \\
\text { - Metodologia de } \\
\text { trabalho com o som no } \\
\text { cinema norte-americano. }\end{array}$ & $\begin{array}{l}\text { - A pós-produção de } \\
\text { som no cinema; } \\
\text { - O Sound design; } \\
\text { - O cinema norte- } \\
\text { americano; } \\
\text { - O cinema brasileiro; } \\
\text { - A trajetória de } \\
\text { Alessandro Laroca. }\end{array}$ & $\begin{array}{l}\text { - A primeira sequência do filme Tropa de } \\
\text { Elite } 2 \text { (José Padilha, 2010); } \\
\text { - Entrevista com o supervisor de edição de } \\
\text { som e mixador Alessandro Laroca. }\end{array}$ \\
\hline Dissertação & $\begin{array}{l}\text { Entre a Escuta e a Visão: } \\
\text { o lugar do espectador na } \\
\text { obra de Robert Bresson / } \\
\text { Pedro Cardoso Aspahan / } \\
2008 .\end{array}$ & $\begin{array}{l}\text { A relação entre a } \\
\text { escritura fílmica e o } \\
\text { lugar do espectador } \\
\text { na obra de Robert } \\
\text { Bresson. }\end{array}$ & $\begin{array}{l}\text { - A linguagem do } \\
\text { cinema em sua relação } \\
\text { com o espectador; } \\
\text { - O som na narrativa } \\
\text { fílmica; } \\
\text { - O princípio de não } \\
\text { redundância entre o } \\
\text { visual e o sonoro; } \\
\text { - A importância } \\
\text { estrutural do silêncio; } \\
\text { - A pedagogia da escuta } \\
\text { cinematográfica e a } \\
\text { pedagogia do olhar. }\end{array}$ & $\begin{array}{l}\text { - A obra de Robert } \\
\text { Bresson; } \\
\text { - O espectador; } \\
\text { - A escuta e o olhar. }\end{array}$ & $\begin{array}{l}\text { - Os filmes de Bresson: Os assuntos } \\
\text { públicos (1934); Um condenado à morte } \\
\text { escapou ou O vento sopra onde quer } \\
\text { (1956) e Uma criatura dócil (1969). }\end{array}$ \\
\hline Dissertação & $\begin{array}{l}\text { Expressividade Oral no } \\
\text { Cinema: diálogos com a } \\
\text { fonoaudiologia / Priscila } \\
\text { Haydée Souza / } 2010 .\end{array}$ & $\begin{array}{l}\text { A expressividade oral } \\
\text { no cinema. }\end{array}$ & $\begin{array}{l}\text { A voz e a fala no } \\
\text { cinema. }\end{array}$ & $\begin{array}{l}\text { - A fonoaudiologia; } \\
\text { - A voz no cinema. }\end{array}$ & $\begin{array}{l}\text { - Entrevista semi-abertas com profissionais } \\
\text { do meio: seis diretores, seis atores e uma } \\
\text { editora de som. }\end{array}$ \\
\hline Dissertação & $\begin{array}{l}\text { Introdução à Arqueologia } \\
\text { da Escuta ou o } \\
\text { Nascimento do Cinema } \\
\text { Sonoro a partir do } \\
\text { Espírito da Ópera / Ivan } \\
\text { Capeller / } 2005 \text {. }\end{array}$ & $\begin{array}{l}\text { Arqueologia da } \\
\text { escuta. }\end{array}$ & $\begin{array}{l}\text { - Historicidade dos } \\
\text { regimes de escuta; } \\
\text { - Tipologias da escuta; } \\
\text { - A reformulação da } \\
\text { história do cinema } \\
\text { sonoro; } \\
\text { - Abordagem } \\
\text { arqueológica da história. }\end{array}$ & $\begin{array}{l}\text { - História do cinema; } \\
\text { - Regimes de escuta. }\end{array}$ & $\begin{array}{l}\text { - Arquivos da escuta nos períodos entre os } \\
\text { anos de } 1200 \text { a } 1950,1600 \text { a } 1950 \text { e } 1880 \text { a } \\
2005 .\end{array}$ \\
\hline Dissertação & $\begin{array}{l}\text { O Cinema, uma arte } \\
\text { sonora / Virginia Flores / } \\
2006 .\end{array}$ & $\begin{array}{l}\text { O som e seus modos } \\
\text { de utilização no } \\
\text { cinema. }\end{array}$ & $\begin{array}{l}\text { - Os pressupostos } \\
\text { organizacionais da } \\
\text { escuta e do fazer do som } \\
\text { fílmico; } \\
\text { - O som na narrativa } \\
\text { fílmica; } \\
\text { - As formas de recepção } \\
\text { do som no cinema. }\end{array}$ & $\begin{array}{l}\text { - A escuta; } \\
\text { - Teoria da música } \\
\text { eletroacústica; } \\
\text { - O fazer do som } \\
\text { fílmico. }\end{array}$ & $\begin{array}{l}\text { - Trechos dos filmes: Blow Up } \\
\text { (Michelangelo Antonioni, 1967), Um tiro } \\
\text { na noite (Brian de Palma, 1981) e } O \\
\text { Pântano (Lucrecia Martel, 2001). }\end{array}$ \\
\hline Dissertação & $\begin{array}{l}\text { O Surround e a } \\
\text { Espacialidade Sonora no } \\
\text { Cinema / Nélio Costa / } \\
\text { 2004a. }\end{array}$ & $\begin{array}{l}\text { O surround e a } \\
\text { espacialidade sonora } \\
\text { no cinema. }\end{array}$ & $\begin{array}{l}\text { - História da tecnologia } \\
\text { do som no cinema; } \\
\text { - A estereofonia digital } \\
\text { no cinema. }\end{array}$ & $\begin{array}{l}\text { - Tecnologia } \\
\text { estereofônica analógica; } \\
\text { - Tecnologia } \\
\text { estereofônica digital; } \\
\text { - Espacialidade sonora } \\
\text { no cinema; } \\
\text { - O cinema norte- } \\
\text { americano. }\end{array}$ & - \\
\hline Dissertação & $\begin{array}{l}\text { O Compositor Stanley } \\
\text { Kubrick: análise do som } \\
\text { do filme De Olhos Bem } \\
\text { Fechados de Stanley } \\
\text { Kubrick através da teoria } \\
\text { sonora de Michel Chion / } \\
\text { Márcio Cardoso } \\
\text { Marcolino / } 2008 .\end{array}$ & $\begin{array}{l}\text { O som do filme De } \\
\text { Olhos Bem Fechados } \\
\text { (Stanley Kubrick, } \\
\text { 1999). }\end{array}$ & - & $\begin{array}{l}\text { - A teoria sonora de } \\
\text { Michel Chion; } \\
\text { - O diretor Stanley } \\
\text { Kubrick. }\end{array}$ & $\begin{array}{l}\text { - O filme De Olhos Bem Fechados } \\
\text { (Stanley Kubrick, 1999). }\end{array}$ \\
\hline
\end{tabular}




\begin{tabular}{|c|c|c|c|c|c|}
\hline Dissertação & $\begin{array}{l}\text { O Lugar Fora do Lugar: } \\
\text { topografias sonoras do } \\
\text { cinema documentário / } \\
\text { Frederico Pessoa / } 2011 .\end{array}$ & $\begin{array}{l}\text { O som no cinema } \\
\text { documentário. }\end{array}$ & $\begin{array}{l}\text { - Funções do som no } \\
\text { cinema; } \\
\text { - Seis modos de } \\
\text { estruturação de } \\
\text { argumentos/narrativas } \\
\text { do cinema documental; } \\
\text { - O lugar ético-político } \\
\text { no documentário. }\end{array}$ & $\begin{array}{l}\text { - O cinema } \\
\text { documentário. }\end{array}$ & $\begin{array}{l}\text { - Os filmes Entuziazm ou Sinfonia } \\
\text { Donbassa (Dziga Vertov, 1931), Titicut } \\
\text { Follies (Frederick Wiseman, 1967), Chulas } \\
\text { Fronteras (Les Blank, 1974) e The } \\
\text { Invisible Frame (Cynthia Beatt, 1974). }\end{array}$ \\
\hline Dissertação & $\begin{array}{l}\text { Se Podes Ouvir, Escuta: a } \\
\text { gênese audiovisual de } \\
\text { Ensaio Sobre a Cegueira / } \\
\text { Kira Pereira / } 2010 .\end{array}$ & $\begin{array}{l}\text { O processo de criação } \\
\text { do som no filme } \\
\text { Ensaio Sobre a } \\
\text { Cegueira (Fernando } \\
\text { Meirelles, 2008). }\end{array}$ & $\begin{array}{l}\text { - O som na narrativa } \\
\text { filmica. }\end{array}$ & $\begin{array}{l}\text { - Etapas da produção } \\
\text { sonora cinematográfica; } \\
\text { - Processo de criação. }\end{array}$ & $\begin{array}{l}\text { - O filme Ensaio Sobre a Cegueira } \\
\text { (Fernando Meirelles, 2008); } \\
\text { - O livro Ensaio Sobre a Cegueira de José } \\
\text { Saramago; } \\
\text { - O roteiro utilizado para a filmagem; } \\
\text { - Os cortes } 1 \text { e } 7 \text { da montagem; } \\
\text { - A sessão de mixagem antes de ser } \\
\text { enviada ao Festival de Cannes e a versão } \\
\text { final do filme apresentada comercialmente } \\
\text { nas salas de cinema; } \\
\text { - Entrevista com os profissionais: } \\
\text { Fernando Meirelles, Guilherme Ayrosa, } \\
\text { Daniel Rezende, Alessandro Laroca, } \\
\text { Marco Antonio Guimarães e Armando } \\
\text { Torres Jr.. }\end{array}$ \\
\hline Dissertação & $\begin{array}{l}\text { Som no Cinema, Silêncio } \\
\text { nos Filmes: o inexplorado } \\
\text { e o inaudito / Fernando } \\
\text { Morais da Costa / 2003a. }\end{array}$ & $\begin{array}{l}\text { A função do som no } \\
\text { cinema, na teoria e na } \\
\text { análise fílmica. }\end{array}$ & $\begin{array}{l}\text { - O silêncio como parte } \\
\text { integrante do som no } \\
\text { cinema; } \\
\text { - A inserção do som no } \\
\text { cinema; } \\
\text { - A primazia da visão; } \\
\text { - O som na narrativa } \\
\text { fílmica; } \\
\text { - O espaço reservado ao } \\
\text { som na teoria e na } \\
\text { análise fílmica. }\end{array}$ & $\begin{array}{l}\text { - Tecnologia do som no } \\
\text { cinema; } \\
\text { - O estudo do som; } \\
\text { - A teoria e a análise } \\
\text { fílmica; } \\
\text { - O silêncio e o ruído. }\end{array}$ & $\begin{array}{l}\text { - O filme O Silêncio (Mohsen } \\
\text { Makhmalbaf, 1998). }\end{array}$ \\
\hline Dissertação & $\begin{array}{l}\text { Sonologia e Cinema: } \\
\text { elementos para análise } \\
\text { áudio-visual / Alexandre } \\
\text { Bräutigam / } 2007 .\end{array}$ & $\begin{array}{l}\text { Análise e descrição } \\
\text { do som no cinema. }\end{array}$ & $\begin{array}{l}\text { - Convergências entre } \\
\text { música eletro-acústica, } \\
\text { cinema sonoro e } \\
\text { situações limites entre } \\
\text { estas artes. }\end{array}$ & $\begin{array}{l}\text { - Teoria da música } \\
\text { eletroacústica; } \\
\text { - Cinema sonoro. }\end{array}$ & - \\
\hline Dissertação & $\begin{array}{l}\text { Um Estudo da } \\
\text { Performance da Oralidade } \\
\text { no Cinema: registros da } \\
\text { voz na linguagem } \\
\text { documental / Elen } \\
\text { Döppenschmitt / } 2005 \text {. }\end{array}$ & $\begin{array}{l}\text { A voz no cinema } \\
\text { documentário. }\end{array}$ & $\begin{array}{l}\text { - A performance da voz; } \\
\text { - A oralidade nas mídias; } \\
\text { - O diálogo entre o } \\
\text { sistema oral e visual. }\end{array}$ & $\begin{array}{l}\text { - A voz no cinema; } \\
\text { - O cinema } \\
\text { documentário. }\end{array}$ & $\begin{array}{l}\text { - O documentário Adão ou Somos Todos } \\
\text { Filhos da Terra (Walter Salles e Daniella } \\
\text { Thomas, 1998). }\end{array}$ \\
\hline Artigo & $\begin{array}{l}\text { À beira da piscina, à beira } \\
\text { do quadro: a utilização do } \\
\text { som off e a construção de } \\
\text { tensão na obra de } \\
\text { Lucrecia Martel / Natalia } \\
\text { Barrenha e Antônio } \\
\text { Passos / } 2009 .\end{array}$ & $\begin{array}{l}\text { O som off nos filmes } \\
\text { da cineasta argentina } \\
\text { Lucrecia Martel. }\end{array}$ & $\begin{array}{l}\text { - Estudo analítico- } \\
\text { interpretativo dos filmes } \\
\text { de Lucrecia Martel. }\end{array}$ & $\begin{array}{l}\text { - O cinema argentino; } \\
\text { - O som nos filmes de } \\
\text { Lucrecia Martel. }\end{array}$ & $\begin{array}{l}\text { - Os filmes de Lucrecia Martel: O Pântano } \\
\text { (2001), A Menina Santa (2004) e A Mulher } \\
\text { Sem Cabeça (2008). }\end{array}$ \\
\hline Artigo & $\begin{array}{l}\text { A difícil relação entre } \\
\text { imagem e som no } \\
\text { audiovisual } \\
\text { contemporâneo / Luciene } \\
\text { Belleboni / } 2004 \text {. }\end{array}$ & $\begin{array}{l}\text { A relação entre som e } \\
\text { imagem no } \\
\text { audiovisual. }\end{array}$ & $\begin{array}{l}\text {-Diferentes formas de } \\
\text { relação entre som e } \\
\text { imagem; } \\
\text { - A primazia da visão. }\end{array}$ & $\begin{array}{l}\text { - Linguagem } \\
\text { audiovisual. }\end{array}$ & - \\
\hline Artigo & $\begin{array}{l}\text { A Escuta Fílmica: uma } \\
\text { atitude estética / Virginia } \\
\text { Flores / } 2007 .\end{array}$ & A escuta fílmica. & $\begin{array}{l}\text { - As formas de recepção } \\
\text { do som no cinema. }\end{array}$ & $\begin{array}{l}\text { - Modos de escuta; } \\
\text { - A escuta filmica. }\end{array}$ & - \\
\hline
\end{tabular}




\begin{tabular}{|c|c|c|c|c|c|}
\hline Artigo & $\begin{array}{l}\text { A Fonoaudiologia e o ator } \\
\text { de cinema: relatos de } \\
\text { profissionais do meio } \\
\text { cinematográfico / Léslie } \\
\text { Ferreira, Vitoria Amaral e } \\
\text { Priscila Haydée Souza / } \\
\text { 2010a. }\end{array}$ & $\begin{array}{l}\text { O trabalho } \\
\text { desenvolvido com a } \\
\text { voz e a fala no } \\
\text { cinema com ênfase } \\
\text { na atuação } \\
\text { fonoaudiológica. }\end{array}$ & $\begin{array}{l}\text { - A expressividade oral } \\
\text { no cinema. }\end{array}$ & $\begin{array}{l}\text { - A fonoaudiologia; } \\
\text { - A voz no cinema; } \\
\text { - O ator de cinema; }\end{array}$ & $\begin{array}{l}\text { - Entrevista semi-abertas com três atores, } \\
\text { quatro fonoaudiólogas e um diretor. }\end{array}$ \\
\hline Artigo & $\begin{array}{l}\text { A Inserção do Som no } \\
\text { Cinema: percalços na } \\
\text { passagem de um meio } \\
\text { visual para audiovisual / } \\
\text { Fernando Morais da } \\
\text { Costa / 2003f. }\end{array}$ & $\begin{array}{l}\text { A inserção do som no } \\
\text { cinema. }\end{array}$ & $\begin{array}{l}\text { - A primazia da visão. } \\
\text { - O som na narrativa } \\
\text { fílmica. }\end{array}$ & $\begin{array}{l}\text { - Tecnologia do som no } \\
\text { cinema; } \\
\text { - Teorias sobre o cinema } \\
\text { falado. }\end{array}$ & - \\
\hline Artigo & $\begin{array}{l}\text { A Narrativa } \\
\text { Fonocinematográfica em } \\
\text { O Silêncio: audição } \\
\text { subjetiva e cronotopias do } \\
\text { espaço filmico / Mauricio } \\
\text { Caleiro / } 2011 \text {. }\end{array}$ & $\begin{array}{l}\text { As abordagens } \\
\text { sonoras empregadas } \\
\text { no filme } O \text { Silêncio } \\
\text { (Mohsen } \\
\text { Makhmalbaf, 1998). }\end{array}$ & $\begin{array}{l}\text { - O som na narrativa } \\
\text { filmica. }\end{array}$ & - Os estudos de cinema. & $\begin{array}{l}\text { - O filme O Silêncio (Mohsen } \\
\text { Makhmalbaf, 1998). }\end{array}$ \\
\hline Artigo & $\begin{array}{l}\text { A Nova Sonoridade do } \\
\text { Cinema em São Paulo / } \\
\text { Andre Gatti e Eduardo } \\
\text { Santos Mendes / } 2008 .\end{array}$ & $\begin{array}{l}\text { O desenvolvimento } \\
\text { do som no cinema. }\end{array}$ & $\begin{array}{l}\text { - Evolução técnica, } \\
\text { profíssional e estética do } \\
\text { som no cinema. } \\
\text { - O som na retomada do } \\
\text { cinema brasileiro. }\end{array}$ & $\begin{array}{l}\text { - Tecnologia do som no } \\
\text { cinema; } \\
\text { - Os profissionais e os } \\
\text { processos de trabalho } \\
\text { com o som no cinema; } \\
\text { - Estética do som no } \\
\text { cinema; } \\
\text { - O cinema paulistano. }\end{array}$ & - \\
\hline Artigo & $\begin{array}{l}\text { A Paisagem Sonora } \\
\text { Eletrônica: a reconstrução } \\
\text { do mundo sonoro } \\
\text { contemporâneo no } \\
\text { cinema / José Cláudio } \\
\text { Castanheira / 2008a. }\end{array}$ & $\begin{array}{l}\text { A experiência do } \\
\text { cinema segundo um } \\
\text { viés das } \\
\text { Materialidades. }\end{array}$ & $\begin{array}{l}\text { - Descrição } \\
\text { fenomenológica da } \\
\text { experiência } \\
\text { cinematográfica. }\end{array}$ & $\begin{array}{l}\text { - A paisagem sonora } \\
\text { eletrônica; } \\
\text { - A fenomenologia; } \\
\text { - As ciências cognitivas; } \\
\text { - Estudo das } \\
\text { Materialidades. }\end{array}$ & - \\
\hline Artigo & $\begin{array}{l}\text { A Paisagem Sonora e a } \\
\text { Ambientação do Desenho } \\
\text { de Som: os sons ambiente } \\
\text { como localizadores } \\
\text { espaciais e temporais no } \\
\text { filme Ensaio Sobre a } \\
\text { Cegueira / Débora } \\
\text { Opolski / 2009b. }\end{array}$ & $\begin{array}{l}\text { A composição dos } \\
\text { sons ambientes do } \\
\text { filme Ensaio Sobre a } \\
\text { Cegueira (Fernando } \\
\text { Meirelles, 2008). }\end{array}$ & $\begin{array}{l}\text { A relação entre a } \\
\text { composição dos sons } \\
\text { ambientes do filme } \\
\text { Ensaio Sobre a } \\
\text { Cegueira e o conceito de } \\
\text { paisagem sonora de } \\
\text { Murray Schafer. }\end{array}$ & $\begin{array}{l}\text { - A composição dos sons } \\
\text { ambientes; } \\
\text { - Paisagem sonora. }\end{array}$ & $\begin{array}{l}\text { - O filme Ensaio Sobre a Cegueira } \\
\text { (Fernando Meirelles, 2008). }\end{array}$ \\
\hline Artigo & $\begin{array}{l}\text { A Presença do Som: } \\
\text { proposta para uma } \\
\text { investigação material da } \\
\text { experiência sonora no } \\
\text { cinema / José Cláudio } \\
\text { Castanheira / 2009b. }\end{array}$ & $\begin{array}{l}\text { A experiência do } \\
\text { cinema segundo uma } \\
\text { aproximação entre os } \\
\text { estudo das } \\
\text { materialidades e a } \\
\text { fenomenologia. }\end{array}$ & $\begin{array}{l}\text { - A importância do som } \\
\text { na afetação do corpo } \\
\text { imerso no dispositivo } \\
\text { cinematográfico; } \\
\text { - Novos modelos } \\
\text { perceptivos. }\end{array}$ & $\begin{array}{l}\text { - A paisagem sonora } \\
\text { eletrônica; } \\
\text { - Tecnologia do som no } \\
\text { cinema; } \\
\text { - Modelos de escuta no } \\
\text { cinema; } \\
\text { - A fenomenologia; } \\
\text { - Estudo das } \\
\text { Materialidades. }\end{array}$ & - \\
\hline Artigo & $\begin{array}{l}\text { A relação imagem e som } \\
\text { nos filmes de Kubrick / } \\
\text { Eduardo Santos Mendes e } \\
\text { Ney Carrasco / } 2007 .\end{array}$ & $\begin{array}{l}\text { A relação imagem e } \\
\text { som nos filmes do } \\
\text { diretor Stanley } \\
\text { Kubrick. }\end{array}$ & $\begin{array}{l}\text { - O som na narrativa } \\
\text { filmica. }\end{array}$ & $\begin{array}{l}\text { - O diretor Stanley } \\
\text { Kubrick. }\end{array}$ & $\begin{array}{l}\text { - O filme 2001: uma odisséia no espaço } \\
\text { (Stanley Kubrick, 1968). }\end{array}$ \\
\hline Artigo & $\begin{array}{l}\text { A Sinfonia dos Pássaros / } \\
\text { Alfredo Torres / } 2009 .\end{array}$ & $\begin{array}{l}\text { A trilha sonora de } O s \\
\text { Pássaros (Alfred } \\
\text { Hitchcock, 1963). }\end{array}$ & $\begin{array}{l}\text { - O som na narrativa } \\
\text { fílmica. }\end{array}$ & $\begin{array}{l}\text { - A obra de Alfred } \\
\text { Hitchcock. }\end{array}$ & $\begin{array}{l}\text { - O filme Os Pássaros (Alfred Hitchcock, } \\
\text { 1963). }\end{array}$ \\
\hline Artigo & $\begin{array}{l}\text { A Submersão nas Imagens } \\
\text { Sonoras: o som e suas } \\
\text { dimensões reais e } \\
\text { imaginárias / Damyler } \\
\text { Cunha / } 2011 \text {. }\end{array}$ & $\begin{array}{l}\text { O ruído fora de } \\
\text { campo como força } \\
\text { expressiva cênica. }\end{array}$ & $\begin{array}{l}\text { A incongruência entre o } \\
\text { que é visto e o que é } \\
\text { ouvido na tela. }\end{array}$ & $\begin{array}{l}\text { - O ruído fora de campo; } \\
\text { - Som acusmático. }\end{array}$ & $\begin{array}{l}\text { - Os filmes: Hamaca Paraguaya (Paz } \\
\text { Encina, 2006); O Pântano (Lucrecia } \\
\text { Martel, 2001) e A Mulher Sem Cabeça } \\
\text { (Lucrecia Martel, 2008). }\end{array}$ \\
\hline
\end{tabular}




\begin{tabular}{|c|c|c|c|c|c|}
\hline Artigo & $\begin{array}{l}\text { A trilha sonora de um } \\
\text { filme imaginário: uma } \\
\text { análise do filme } B L U E \\
\text { (1993) de Derek Jarman / } \\
\text { Fabiana Quintana / } 2010 .\end{array}$ & $\begin{array}{l}\text { Análise da trilha } \\
\text { sonora do filme } \\
B L U E \text { (Derek } \\
\text { Jarman, 1993). }\end{array}$ & $\begin{array}{l}\text { - O som na narrativa } \\
\text { filmica. }\end{array}$ & $\begin{array}{l}\text { - A obra de Derek } \\
\text { Jarman. }\end{array}$ & - O filme BLUE (Derek Jarman, 1993). \\
\hline Artigo & $\begin{array}{l}\text { A Trilha Sonora do } \\
\text { Cinema: proposta para um } \\
\text { "ouvir" analítico / Márcia } \\
\text { Carvalho da Silva / } 2007 .\end{array}$ & $\begin{array}{l}\text { Análise da trilha } \\
\text { sonora no cinema. }\end{array}$ & $\begin{array}{l}\text { - Classificação dos } \\
\text { elementos da trilha } \\
\text { sonora; } \\
\text { - O som na narrativa } \\
\text { fílmica. }\end{array}$ & $\begin{array}{l}\text { - As três categorias de } \\
\text { Charles Sanders Peirce: } \\
\text { não-representativo, } \\
\text { figurativo e } \\
\text { representativo; } \\
\text { - Os elementos da trilha } \\
\text { sonora cinematográfica: } \\
\text { música, efeito sonoro e } \\
\text { voz. }\end{array}$ & $\begin{array}{l}\text { - O filme Baile Perfumado (Paulo Caldas e } \\
\text { Lírio Ferreira, 1997) }\end{array}$ \\
\hline Artigo & $\begin{array}{l}\text { A voz nas Memórias do } \\
\text { Subdesenvolvimento: de } \\
\text { Edmundo Desnoes a } \\
\text { Tomás Gutiérrez Alea / } \\
\text { Elen Döppenschmitt / } \\
\text { 2007a. }\end{array}$ & $\begin{array}{l}\text { A voz em Memórias } \\
\text { do } \\
\text { Subdesenvolvimento. }\end{array}$ & $\begin{array}{l}\text { - A transcrição da voz na } \\
\text { letra para a voz na tela. }\end{array}$ & $\begin{array}{l}\text { - O cinema cubano; } \\
\text { - A voz no cinema. }\end{array}$ & $\begin{array}{l}\text { - O filme Memórias do } \\
\text { Subdesenvolvimento (Tomás Gutiérrez } \\
\text { Alea, 1968); } \\
\text { - O livro Memórias do } \\
\text { Subdesenvolvimento (Edmundo Desnoes, } \\
\text { 1965); }\end{array}$ \\
\hline Artigo & $\begin{array}{l}\text { Além do que se vê: o som } \\
\text { e as paisagens sonoras no } \\
\text { documentário Dong, de } \\
\text { Jia Zhang-ke / Isaac } \\
\text { Pipano / } 2011 .\end{array}$ & $\begin{array}{l}\text { O som e as paisagens } \\
\text { sonoras no } \\
\text { documentário Dong, } \\
\text { de Jia Zhang-ke. }\end{array}$ & $\begin{array}{l}\text { - O som na narrativa } \\
\text { filmica. }\end{array}$ & $\begin{array}{l}\text { - A obra de Jia Zhang- } \\
\text { ke; } \\
\text { - Paisagem sonora. }\end{array}$ & - O filme Dong (Jia Zhang-ke, 2006) \\
\hline Artigo & $\begin{array}{l}\text { As ideias da trilha sonora } \\
\text { do filme Akira / José } \\
\text { Eduardo Bozicanin / } \\
2008 .\end{array}$ & $\begin{array}{l}\text { A trilha sonora do } \\
\text { filme Akira } \\
\text { (Katsuhiro Ôtomo, } \\
\text { 1988). }\end{array}$ & $\begin{array}{l}\text { - O som na narrativa } \\
\text { filmica. }\end{array}$ & $\begin{array}{l}\text { - O cinema de } \\
\text { animação; } \\
\text { - Processo de criação. }\end{array}$ & - O filme Akira (Katsuhiro Ôtomo, 1988). \\
\hline Artigo & $\begin{array}{l}\text { Candinho: a construção } \\
\text { do espaço narrativo } \\
\text { através da relação } \\
\text { imagem-som / Kira } \\
\text { Pereira / 2009a. }\end{array}$ & $\begin{array}{l}\text { Análise da relação } \\
\text { imagem e som do } \\
\text { média-metragem } \\
\text { Candinho (Ozualdo } \\
\text { Candeias, 1976). }\end{array}$ & $\begin{array}{l}\text { - O som na narrativa } \\
\text { filmica. }\end{array}$ & $\begin{array}{l}\text { - Análise audiovisual } \\
\text { focada no elemento } \\
\text { sonoro. }\end{array}$ & $\begin{array}{l}\text { - O filme Candinho (Ozualdo Candeias, } \\
\text { 1976). }\end{array}$ \\
\hline Artigo & $\begin{array}{l}\text { Como soa hoje } \\
\text { experimental? / Fernando } \\
\text { Morais da Costa / 2011b. }\end{array}$ & $\begin{array}{l}\text { O uso do som no } \\
\text { cinema } \\
\text { contemporâneo. }\end{array}$ & $\begin{array}{l}\text { - Inovações sonoras no } \\
\text { cinema contemporâneo; } \\
\text { - O som na narrativa } \\
\text { fílmica. }\end{array}$ & $\begin{array}{l}\text { - O cinema } \\
\text { contemporâneo. }\end{array}$ & - \\
\hline Artigo & $\begin{array}{l}\text { De Olhos e Ouvidos Bem } \\
\text { Abertos: uma } \\
\text { classificação dos sons no } \\
\text { cinema / Márcia Carvalho } \\
\text { da Silva / } 2008 .\end{array}$ & $\begin{array}{l}\text { Análise da trilha } \\
\text { sonora no cinema. }\end{array}$ & $\begin{array}{l}\text { - Classificação dos } \\
\text { elementos da trilha } \\
\text { sonora: } \\
\text { - O som na narrativa } \\
\text { filmica. }\end{array}$ & $\begin{array}{l}\text { - As três categorias de } \\
\text { Charles Sanders Peirce: } \\
\text { não-representativo, } \\
\text { figurativo e } \\
\text { representativo; } \\
\text { - Os elementos da trilha } \\
\text { sonora cinematográfica: } \\
\text { música, efeito sonoro e } \\
\text { voz. }\end{array}$ & - \\
\hline Artigo & $\begin{array}{l}\text { Diálogos sobre a imagem } \\
\text { visual e a imagem sonora: } \\
\text { a experiência de escritura } \\
\text { do sonoro nos } \\
\text { documentários } \\
\text { etnográficos / Viviane } \\
\text { Vedana / } 2011 .\end{array}$ & $\begin{array}{l}\text { A montagem de } \\
\text { documentários } \\
\text { etnográficos sob a } \\
\text { perspectiva da banda } \\
\text { sonora. }\end{array}$ & $\begin{array}{l}\text { - O som na narrativa } \\
\text { filmica; } \\
\text { - Documentários } \\
\text { etnográficos. }\end{array}$ & $\begin{array}{l}\text { - O cinema } \\
\text { documentário. }\end{array}$ & $\begin{array}{l}\text { - O Banco de Imagens e Efeitos Visuais } \\
\text { (Biev) da UFRGS. }\end{array}$ \\
\hline
\end{tabular}




\begin{tabular}{|c|c|c|c|c|c|}
\hline Artigo & $\begin{array}{l}\text { Efeitos Sonoros Enquanto } \\
\text { Fala Audiovisual: análise } \\
\text { de Gerald McBoing- } \\
\text { Boing à luz do } \$ 528 \text { das } \\
\text { Investigações Filosóficas / } \\
\text { Rafael Venancio / } 2011 .\end{array}$ & $\begin{array}{l}\text { O uso do som no } \\
\text { cinema de animação. }\end{array}$ & $\begin{array}{l}\text { - Os efeitos sonoros } \\
\text { enquanto fala } \\
\text { audiovisual; } \\
\text { - O fenômeno language- } \\
\text { like praticado em Gerald } \\
\text { McBoing-Boing. }\end{array}$ & $\begin{array}{l}\text { - O cinema de } \\
\text { animação; } \\
\text { - A produção dos } \\
\text { estúdios da UPA } \\
\text { (United Productions of } \\
\text { America); } \\
\text { - A obra "Investigações } \\
\text { Filosóficas" de Ludwig } \\
\text { Wittgenstein; } \\
\text { - O fenômeno language- } \\
\text { like. }\end{array}$ & $\begin{array}{l}\text { - Os filmes e o personagem Gerald } \\
\text { McBoing-Boing. }\end{array}$ \\
\hline Artigo & $\begin{array}{l}\text { Electronic Tonalities: o } \\
\text { espaço eletrônico e a } \\
\text { impressão de realidade na } \\
\text { ficção científica / José } \\
\text { Cláudio Castanheira / } \\
\text { 2008b. }\end{array}$ & $\begin{array}{l}\text { O espaço eletrônico e } \\
\text { a impressão de } \\
\text { realidade na ficção } \\
\text { científica. }\end{array}$ & $\begin{array}{l}\text { - A participação do som } \\
\text { na construção da } \\
\text { impressão de realidade } \\
\text { na experiência } \\
\text { cinematográfica; } \\
\text { - Novos modelos } \\
\text { perceptivos. }\end{array}$ & $\begin{array}{l}\text { - O som eletrônico no } \\
\text { cinema. }\end{array}$ & - Filmes de ficção científica. \\
\hline Artigo & $\begin{array}{l}\text { Escutando o Cinema / } \\
\text { Gerson Leme / } 2008 .\end{array}$ & $\begin{array}{l}\text { A criação sonora } \\
\text { audiovisual. }\end{array}$ & $\begin{array}{l}\text { Os elementos, as etapas } \\
\text { e o trabalho com a } \\
\text { produção sonora } \\
\text { cinematográfica. }\end{array}$ & $\begin{array}{l}\text { - As camadas de som no } \\
\text { cinema; } \\
\text { - Ouvir x escutar; } \\
\text { - Os elementos sonoros } \\
\text { do cinema. }\end{array}$ & - \\
\hline Artigo & $\begin{array}{l}\text { Escutar tanto quanto se vê } \\
\text { (como um filme iraniano, } \\
\text { sobre uma criança cega, } \\
\text { pode ensinar a ouvir?) / } \\
\text { Fernando Morais da } \\
\text { Costa / 2003b. }\end{array}$ & $\begin{array}{l}\text { A importância da } \\
\text { audição na infância. }\end{array}$ & - A primazia da visão. & $\begin{array}{l}\text { - Percepção sensorial } \\
\text { infantil. }\end{array}$ & $\begin{array}{l}\text { - O filme } O \text { Silêncio (Mohsen } \\
\text { Makhmalbaf, 1998). }\end{array}$ \\
\hline Artigo & $\begin{array}{l}\text { Introdução à Arqueologia } \\
\text { da Escuta: do som e da } \\
\text { voz como objetos de } \\
\text { enunciação / Ivan } \\
\text { Capeller / } 2011 .\end{array}$ & $\begin{array}{l}\text { Arqueologia da } \\
\text { escuta. }\end{array}$ & $\begin{array}{l}\text { - Historicidade dos } \\
\text { regimes de escuta; } \\
\text { - Tipologias da escuta; } \\
\text { - A reformulação da } \\
\text { história do cinema } \\
\text { sonoro; } \\
\text { - Abordagem } \\
\text { arqueológica da história. }\end{array}$ & $\begin{array}{l}\text { - História do cinema; } \\
\text { - Regimes de escuta. }\end{array}$ & - \\
\hline Artigo & $\begin{array}{l}\text { Lucrecia Martel e o } \\
\text { benefício da incerteza / } \\
\text { Eduardo Santos Mendes e } \\
\text { Ivonete Pinto / } 2005 .\end{array}$ & $\begin{array}{l}\text { A relação audiovisual } \\
\text { na obra de Lucrecia } \\
\text { Martel. }\end{array}$ & - & $\begin{array}{l}\text { - A cineasta Lucrecia } \\
\text { Martel. }\end{array}$ & $\begin{array}{l}\text { - O filme } A \text { Menina Santa (Lucrecia } \\
\text { Martel, 2004) }\end{array}$ \\
\hline Artigo & $\begin{array}{l}\text { O Artista Silencioso: um } \\
\text { estudo da construção } \\
\text { sonora no filme do } \\
\text { Cineclube Universitário } \\
\text { de Campinas / Natasha } \\
\text { Almeida / } 2011 \text {. }\end{array}$ & $\begin{array}{l}\text { A construção do } \\
\text { espaço sonoro no } \\
\text { curta-metragem } O \\
\text { Artista (Luiz Carlos } \\
\text { Ribeiro Borges, } \\
\text { 1967). }\end{array}$ & $\begin{array}{l}\text { - A influência exercida } \\
\text { sobre o filme pelo } \\
\text { cinema silencioso } \\
\text { campineiro, produzidos } \\
\text { nos anos } 1920 \text {, e pela } \\
\text { chegada do som a suas } \\
\text { salas de exibição. }\end{array}$ & - O cinema campineiro. & $\begin{array}{l}\text { - O curta-metragem O Artista (Luiz Carlos } \\
\text { Ribeiro Borges, 1967); } \\
\text { - O cineclube universitário de Campinas- } \\
\text { SP; }\end{array}$ \\
\hline Artigo & $\begin{array}{l}\text { O ensaio no documentário } \\
\text { e a questão da narração } \\
\text { em off / Consuelo Lins / } \\
2007 .\end{array}$ & $\begin{array}{l}\text { As possibilidades } \\
\text { estéticas do uso da } \\
\text { narração em off no } \\
\text { documentário. }\end{array}$ & $\begin{array}{l}\text { - A estética do } \\
\text { documentário brasileiro. }\end{array}$ & $\begin{array}{l}\text { - O cinema } \\
\text { documentário brasileiro; } \\
\text { - O cinema } \\
\text { documentário francês; } \\
\text { - A narração em off. }\end{array}$ & $\begin{array}{l}\text { - As obras dos cineastas Chris Marker e } \\
\text { Agnès Varda. }\end{array}$ \\
\hline Artigo & $\begin{array}{l}\text { O rádio e os silêncios: } \\
\text { articulações sobre o uso } \\
\text { do som em Cinema, } \\
\text { aspirinas e urubus / } \\
\text { Rodrigo Carreiro / 2010a. }\end{array}$ & $\begin{array}{l}\text { O uso do som no } \\
\text { filme Cinema, } \\
\text { aspirinas e urubus } \\
\text { (Marcelo Gomes, } \\
\text { 2005). }\end{array}$ & $\begin{array}{l}\text { - A articulação entre o } \\
\text { som e elementos da } \\
\text { encenação no filme } \\
\text { Cinema, aspirinas e } \\
\text { urubus (Marcelo } \\
\text { Gomes, 2005). }\end{array}$ & $\begin{array}{l}\text { - O rádio e os silêncios } \\
\text { no filme Cinema, } \\
\text { aspirinas e urubus } \\
\text { (Marcelo Gomes, 2005). }\end{array}$ & $\begin{array}{l}\text { - O filme Cinema, aspirinas e urubus } \\
\text { (Marcelo Gomes, 2005). }\end{array}$ \\
\hline
\end{tabular}




\begin{tabular}{|c|c|c|c|c|c|}
\hline Artigo & $\begin{array}{l}\text { O Som Eletrônico no } \\
\text { Cinema: uma abordagem } \\
\text { fenomenológica / José } \\
\text { Cláudio Castanheira / } \\
\text { 2010b. }\end{array}$ & $\begin{array}{l}\text { A experiência do } \\
\text { cinema segundo uma } \\
\text { aproximação } \\
\text { fenomenológica. }\end{array}$ & $\begin{array}{l}\text { - Novas audibilidades no } \\
\text { cinema; } \\
\text { - Novos modelos } \\
\text { perceptivos. }\end{array}$ & $\begin{array}{l}\text { - O som eletrônico no } \\
\text { cinema; } \\
\text { - A fenomenologia; } \\
\text { - Estudo das } \\
\text { Materialidades; } \\
\text { - As ciências cognitivas. }\end{array}$ & - \\
\hline Artigo & $\begin{array}{l}\text { O Som Expandido: os } \\
\text { novos espaços do som no } \\
\text { cinema / José Cláudio } \\
\text { Castanheira / 2011b. }\end{array}$ & $\begin{array}{l}\text { Novos espaços do } \\
\text { som no cinema }\end{array}$ & $\begin{array}{l}\text { - Novas audibilidades no } \\
\text { cinema; } \\
\text { - Novos modelos } \\
\text { perceptivos. }\end{array}$ & $\begin{array}{l}\text { - Tecnologia do som no } \\
\text { cinema; } \\
\text { - Modelos de escuta; } \\
\text { - As ciências cognitivas. }\end{array}$ & - Os sistemas Dolby, Sensurround e THX. \\
\hline Artigo & $\begin{array}{l}\text { O som surround e suas } \\
\text { formas de uso / Aline } \\
\text { Pedreiras / } 2008 .\end{array}$ & O som surround. & $\begin{array}{l}\text { - Tecnologia } \\
\text { estereofônica digital no } \\
\text { cinema; } \\
\text { - Espacialidade sonora } \\
\text { no cinema. }\end{array}$ & $\begin{array}{l}\text { - O sistema surround } \\
\text { 5.1. }\end{array}$ & $\begin{array}{l}\text { - O formato de som multicanal digital: } \\
\text { Dolby Digital. }\end{array}$ \\
\hline Artigo & $\begin{array}{l}\text { O Sonho de Edison: o } \\
\text { advento do som } \\
\text { sincronizado / Ney } \\
\text { Carrasco / } 2003 \text {. }\end{array}$ & $\begin{array}{l}\text { A inserção do som no } \\
\text { cinema. }\end{array}$ & $\begin{array}{l}\text { - Principais experiências } \\
\text { de união entre som e } \\
\text { imagem no cinema. }\end{array}$ & $\begin{array}{l}\text { - Tecnologia do som no } \\
\text { cinema; } \\
\text { - O inventor Thomas } \\
\text { Edison. }\end{array}$ & - \\
\hline Artigo & $\begin{array}{l}\text { O Soundscape da } \\
\text { Modernidade: os Sound } \\
\text { Studies e o som no cinema } \\
\text { / José Cláudio } \\
\text { Castanheira / 2011a. }\end{array}$ & $\begin{array}{l}\text { Os Sound Studies e o } \\
\text { som no cinema. }\end{array}$ & $\begin{array}{l}\text { - O som como objeto de } \\
\text { estudo para o cinema e } \\
\text { para as práticas sociais } \\
\text { de um modo geral. }\end{array}$ & $\begin{array}{l}\text { - Os Sound Studies; } \\
\text { - A Sound Art. }\end{array}$ & - \\
\hline Artigo & $\begin{array}{l}\text { Orfeu: do mito a realidade } \\
\text { brasileira. A importância } \\
\text { da trilha sonora na } \\
\text { estratégia narrativa de } \\
\text { Cacá Diegues e sua } \\
\text { relação com o contexto } \\
\text { sociocultural de uma } \\
\text { época / Fabiana } \\
\text { Quintana / } 2009 .\end{array}$ & $\begin{array}{l}\text { Análise da trilha } \\
\text { sonora do filme } \\
\text { Orfeu (Cacá Diegues. } \\
\text { 1999). }\end{array}$ & $\begin{array}{l}\text { - O som na narrativa } \\
\text { filmica. }\end{array}$ & $\begin{array}{l}\text { - A trilha sonora do } \\
\text { filme Orfeu (Cacá } \\
\text { Diegues. 1999). }\end{array}$ & - O filme Orfeu (Cacá Diegues. 1999). \\
\hline Artigo & $\begin{array}{l}\text { Os caminhos dos usos dos } \\
\text { silêncios (ou a lembrança } \\
\text { que não passa de John } \\
\text { Cage) / Fernando Morais } \\
\text { da Costa / 2011c. }\end{array}$ & $\begin{array}{l}\text { Os usos dos silêncios } \\
\text { no cinema. }\end{array}$ & - & $\begin{array}{l}\text { - O cinema } \\
\text { contemporâneo; } \\
\text { - O silêncio. }\end{array}$ & - \\
\hline Artigo & $\begin{array}{l}\text { Os sons da continuidade } \\
\text { intensificada: o caso de } \\
\text { Sergio Leone / Rodrigo } \\
\text { Carreiro / 2011a. }\end{array}$ & $\begin{array}{l}\text { O uso do som na obra } \\
\text { de Sergio Leone. }\end{array}$ & $\begin{array}{l}\text { - O som na narrativa } \\
\text { filmica. }\end{array}$ & $\begin{array}{l}\text { - A obra de Sergio } \\
\text { Leone; } \\
\text { - O conceito de } \\
\text { continuidade } \\
\text { intensificada de David } \\
\text { Bordwell. }\end{array}$ & $\begin{array}{l}\text { - } 23 \text { westerns realizados entre os anos de } \\
1930 \text { e } 1960 \text { e } 5 \text { de Leone; } \\
\text { - A obra de Sergio Leone. }\end{array}$ \\
\hline Artigo & $\begin{array}{l}\text { Paisagens Sonoras de } \\
\text { Robert Bresson: uma } \\
\text { análise a partir dos } \\
\text { conceitos de Murray } \\
\text { Schafer / Luiza Alvim / } \\
2011 .\end{array}$ & $\begin{array}{l}\text { As paisagens sonoras } \\
\text { dos filmes de Robert } \\
\text { Bresson. }\end{array}$ & $\begin{array}{l}\text { - Os principais sons que } \\
\text { compõem as paisagens } \\
\text { sonoras dos filmes de } \\
\text { Robert Bresson. }\end{array}$ & $\begin{array}{l}\text { - A obra de Robert } \\
\text { Bresson; } \\
\text { - Os conceitos de } \\
\text { Murray Schafer. }\end{array}$ & $\begin{array}{l}\text { - Os filmes de Bresson: Os Anjos do } \\
\text { Pecado (1943); As Damas do Bois de } \\
\text { Boulogne (1945); Diário de um Padre } \\
\text { (1951); Pickpocket (1959); A Grande } \\
\text { Testemunha (1966); Mouchette (1967); } \\
\text { Uma Mulher Doce (1969); Quatro Noites } \\
\text { de um Sonhador (1972); O Diabo } \\
\text { Provavelmente (1977); O Dinheiro } \\
\text { (Robert Bresson, 1983). }\end{array}$ \\
\hline Artigo & $\begin{array}{l}\text { Pensando a trilha sonora } \\
\text { para audiovisual / Gerson } \\
\text { Leme / } 2011 \text {. }\end{array}$ & $\begin{array}{l}\text { Análise da trilha } \\
\text { sonora no cinema. }\end{array}$ & $\begin{array}{l}\text { - Classificação dos } \\
\text { elementos da trilha } \\
\text { sonora. }\end{array}$ & $\begin{array}{l}\text { - Os elementos da trilha } \\
\text { sonora cinematográfica: } \\
\text { música, efeito sonoro e } \\
\text { voz; } \\
\text { - A natureza do material } \\
\text { sonoro. }\end{array}$ & - \\
\hline
\end{tabular}




\begin{tabular}{|c|c|c|c|c|c|}
\hline Artigo & $\begin{array}{l}\text { Pensando a Relação } \\
\text { Imagem-Som / Eduardo } \\
\text { Santos Mendes / } 2004 .\end{array}$ & $\begin{array}{l}\text { A teoria e a análise } \\
\text { sonora fílmica. }\end{array}$ & $\begin{array}{l}\text { - O som na narrativa } \\
\text { filmica. }\end{array}$ & $\begin{array}{l}\text { - O estudo do som; } \\
\text { - A teoria e a análise } \\
\text { fílmica; }\end{array}$ & - \\
\hline Artigo & $\begin{array}{l}\text { Pode o cinema } \\
\text { contemporâneo } \\
\text { representar o ambiente } \\
\text { sonoro em que vivemos? / } \\
\text { Fernando Morais da } \\
\text { Costa / 2010b. }\end{array}$ & $\begin{array}{l}\text { O ruído que nos cerca } \\
\text { como matéria-prima } \\
\text { fundamental para a } \\
\text { produção } \\
\text { cinematográfica } \\
\text { atual. }\end{array}$ & $\begin{array}{l}\text { - O uso do som no } \\
\text { cinema contemporâneo. }\end{array}$ & $\begin{array}{l}\text { - O cinema } \\
\text { contemporâneo; } \\
\text { - Paisagem sonora. }\end{array}$ & - \\
\hline Artigo & $\begin{array}{l}\text { Pode-se dizer que há algo } \\
\text { como um hiper-realismo } \\
\text { sonoro no cinema } \\
\text { argentino? / Fernando } \\
\text { Morais da Costa / 2011a. }\end{array}$ & $\begin{array}{l}\text { O uso do som no } \\
\text { cinema } \\
\text { contemporâneo. }\end{array}$ & $\begin{array}{l}\text { - Hiper-realismo sonoro } \\
\text { no cinema. }\end{array}$ & $\begin{array}{l}\text { - O cinema argentino; } \\
\text { - O cinema } \\
\text { contemporâneo; }\end{array}$ & - \\
\hline Artigo & $\begin{array}{l}\text { Por uma política da voz. } \\
\text { Tomás Gutiérrez Alea e as } \\
\text { Memórias do } \\
\text { Subdesenvolvimento / } \\
\text { Elen Döppenschmitt / } \\
2008 \text {. }\end{array}$ & $\begin{array}{l}\text { A voz em Memórias } \\
\text { do } \\
\text { Subdesenvolvimento. }\end{array}$ & $\begin{array}{l}\text { - A política da voz no } \\
\text { cinema; } \\
\text { - A natureza pedagógica } \\
\text { do cinema de Tomás } \\
\text { Gutiérrez Alea. }\end{array}$ & $\begin{array}{l}\text { - O cinema cubano; } \\
\text { - A voz no cinema. }\end{array}$ & $\begin{array}{l}\text { - O filme Memórias do } \\
\text { Subdesenvolvimento (Tomás Gutiérrez } \\
\text { Alea, 1968); } \\
\text { - O livro Memórias do } \\
\text { Subdesenvolvimento (Edmundo Desnoes, } \\
\text { 1965); }\end{array}$ \\
\hline Artigo & $\begin{array}{l}\text { Pré-escutas: modelos de } \\
\text { audibilidades dos } \\
\text { primeiros cinemas / José } \\
\text { Cláudio Castanheira / } \\
\text { 2009a. }\end{array}$ & $\begin{array}{l}\text { Modelos de } \\
\text { audibilidades dos } \\
\text { primeiros cinemas. }\end{array}$ & $\begin{array}{l}\text { - O surgimento de } \\
\text { códigos narrativos nos } \\
\text { primeiros cinemas. }\end{array}$ & $\begin{array}{l}\text { - Primeiros cinemas; } \\
\text { - Modelos de escuta. }\end{array}$ & $\begin{array}{l}\text { - O vaudeville, o melodrama, as canções } \\
\text { ilustradas, as narrações e os nickelodeons. }\end{array}$ \\
\hline Artigo & $\begin{array}{l}\text { Primeiras tentativas de } \\
\text { sonorização no cinema } \\
\text { brasileiro (os } \\
\text { cinematógrafos falantes } \\
\text { 1902-1908) / Fernando } \\
\text { Morais da Costa / 2006b. }\end{array}$ & $\begin{array}{l}\text { Primeiras tentativas } \\
\text { de sonorização no } \\
\text { cinema brasileiro. }\end{array}$ & $\begin{array}{l}\text { - Os cinematógrafos } \\
\text { falantes de } 1902 \text { a } 1908 .\end{array}$ & $\begin{array}{l}\text { - cinema brasileiro; } \\
\text { - Tecnologia do som no } \\
\text { cinema. }\end{array}$ & $\begin{array}{l}\text { - Os cinematógrafos falantes de } 1902 \text { a } \\
1908 .\end{array}$ \\
\hline Artigo & $\begin{array}{l}\text { Produção Sonora no } \\
\text { Cinema Contemporâneo: } \\
\text { um olhar sobre desafios } \\
\text { do som no cinema } \\
\text { brasileiro e o processo de } \\
\text { finalização de som do } \\
\text { filme Tropa de Elite 2/ } \\
\text { Bernardo Marquez Alves / } \\
2011 \text {. }\end{array}$ & $\begin{array}{l}\text { Processo de criação } \\
\text { na edição de som e } \\
\text { mixagem do filme } \\
\text { Tropa de Elite } 2 \text { (José } \\
\text { Padilha, 2010). }\end{array}$ & $\begin{array}{l}\text { - A realidade brasileira } \\
\text { contemporânea } \\
\text { relacionada à produção } \\
\text { sonora no cinema. }\end{array}$ & $\begin{array}{l}\text { - A pós-produção de } \\
\text { som no cinema; } \\
\text { - A edição de som; } \\
\text { - A mixagem; } \\
\text { - Cinema brasileiro. }\end{array}$ & $\begin{array}{l}\text { - O Filme Tropa de Elite } 2 \text { (José Padilha, } \\
\text { 2010); } \\
\text { - Entrevista com os profissionais: Armando } \\
\text { Torres Jr., Alessandro Laroca e parte de } \\
\text { sua equipe de edição de som. }\end{array}$ \\
\hline Artigo & $\begin{array}{l}\text { Que papel é delegado ao } \\
\text { som, em um meio } \\
\text { audiovisual? A imagem } \\
\text { preponderante, e a } \\
\text { inserção do som no } \\
\text { cinema / Fernando Morais } \\
\text { da Costa / 2003e. }\end{array}$ & $\begin{array}{l}\text { A inserção do som no } \\
\text { cinema. }\end{array}$ & $\begin{array}{l}\text { - O som na narrativa } \\
\text { fílmica; } \\
\text { - A primazia da visão. }\end{array}$ & $\begin{array}{l}\text { - Tecnologia do som no } \\
\text { cinema; } \\
\text { - Teorias sobre o cinema } \\
\text { falado. }\end{array}$ & - \\
\hline Artigo & $\begin{array}{l}\text { Relações entre imagens e } \\
\text { sons no filme Cinema, } \\
\text { Aspirinas e Urubus / } \\
\text { Rodrigo Carreiro / 2010b. }\end{array}$ & $\begin{array}{l}\text { O uso do som no } \\
\text { filme Cinema, } \\
\text { aspirinas e urubus } \\
\text { (Marcelo Gomes, } \\
\text { 2005). }\end{array}$ & $\begin{array}{l}\text { - A articulação entre o } \\
\text { som e elementos da } \\
\text { encenação no filme } \\
\text { Cinema, aspirinas e } \\
\text { urubus (Marcelo } \\
\text { Gomes, 2005). }\end{array}$ & $\begin{array}{l}\text { - O rádio e os silêncios } \\
\text { no filme Cinema, } \\
\text { aspirinas e urubus } \\
\text { (Marcelo Gomes, 2005). }\end{array}$ & $\begin{array}{l}\text { - O filme Cinema, aspirinas e urubus } \\
\text { (Marcelo Gomes, 2005). }\end{array}$ \\
\hline Artigo & $\begin{array}{l}\text { Representações de Voz e } \\
\text { Fala no Cinema / Léslie } \\
\text { Ferreira, Vitoria Amaral, } \\
\text { Maria Laura Martz e } \\
\text { Priscila Haydée Souza / } \\
\text { 2010b. }\end{array}$ & $\begin{array}{l}\text { Representações de } \\
\text { voz e fala no cinema. }\end{array}$ & $\begin{array}{l}\text { O papel interpretativo } \\
\text { dos recursos de voz e } \\
\text { fala em três sequências } \\
\text { do filme Cidade de } \\
\text { Deus (Fernando } \\
\text { Meirelles e Kátia Lund, } \\
\text { 2002). }\end{array}$ & $\begin{array}{l}\text { - A fonoaudiologia; } \\
\text { - A voz no cinema. }\end{array}$ & $\begin{array}{l}\text { - Três sequências do filme Cidade de Deus } \\
\text { (Fernando Meirelles e Kátia Lund, 2002). }\end{array}$ \\
\hline
\end{tabular}




\begin{tabular}{|c|c|c|c|c|c|}
\hline Artigo & $\begin{array}{l}\text { Robert Bresson: o cinema } \\
\text { num atormentado } \\
\text { silêncio / Suzana Dobal / } \\
2003 \text {. }\end{array}$ & $\begin{array}{l}\text { O uso do silêncio na } \\
\text { obra de Robert } \\
\text { Bresson. }\end{array}$ & - & $\begin{array}{l}\text { - O silêncio no cinema; } \\
\text { - O cinema de Robert } \\
\text { Bresson. }\end{array}$ & - \\
\hline Artigo & $\begin{array}{l}\text { Ruídos e Silêncio: } \\
\text { proposta para uma estética } \\
\text { do som no cinema / } \\
\text { Fernando Morais da } \\
\text { Costa / 2003d. }\end{array}$ & $\begin{array}{l}\text { A importância dos } \\
\text { ruídos e do silêncio } \\
\text { no som } \\
\text { cinematográfico. }\end{array}$ & $\begin{array}{l}\text { - A preponderância da } \\
\text { voz sobre os outros } \\
\text { elementos sonoros no } \\
\text { cinema. }\end{array}$ & $\begin{array}{l}\text { - O cinema falado; } \\
\text { - A teoria e a prática das } \\
\text { artes no século XX; } \\
\text { - A preponderância da } \\
\text { voz; } \\
\text { - O silêncio e o ruído. }\end{array}$ & - \\
\hline Artigo & $\begin{array}{l}\text { São Bernardo: mosaico de } \\
\text { vozes (mostruário dos } \\
\text { diversos usos da voz no } \\
\text { cinema) / Fernando } \\
\text { Morais da Costa / 2003c. }\end{array}$ & $\begin{array}{l}\text { Modos alternativos } \\
\text { de utilização da voz } \\
\text { no cinema. }\end{array}$ & $\begin{array}{l}\text { - O uso da voz no filme } \\
\text { São Bernardo (Leon } \\
\text { Hirszman, 1973). }\end{array}$ & - A voz no cinema. & $\begin{array}{l}\text { - O filme São Bernardo (Leon Hirszman, } \\
\text { 1973). }\end{array}$ \\
\hline Artigo & $\begin{array}{l}\text { Se podes ouvir, escuta: } \\
\text { relações audiovisuais do } \\
\text { filme Ensaio Sobre a } \\
\text { Cegueira e considerações } \\
\text { sobre seu processo } \\
\text { criativo / Kira Pereira / } \\
2009 \mathrm{~b} \text {. }\end{array}$ & $\begin{array}{l}\text { O processo de criação } \\
\text { do som do filme } \\
\text { Ensaio Sobre a } \\
\text { Cegueira (Fernando } \\
\text { Meirelles, 2008). }\end{array}$ & $\begin{array}{l}\text { - O som na narrativa } \\
\text { filmica. }\end{array}$ & - Processo de criação. & $\begin{array}{l}\text { - O filme Ensaio Sobre a Cegueira } \\
\text { (Fernando Meirelles, 2008); } \\
\text { - O livro Ensaio Sobre a Cegueira de José } \\
\text { Saramago; . } \\
\text { - O blog Diário de Blindness; } \\
\text { - Os cortes } 1 \text { e } 7 \text { da montagem; } \\
\text { - A palestra proferida pelo diretor Fernando } \\
\text { Meirelles na ECA-USP em outubro de } \\
\text { 2008; } \\
\text { - A entrevista concedida por Fernando } \\
\text { Meirelles ao programa Roda Viva, da TV } \\
\text { cultura. }\end{array}$ \\
\hline Artigo & $\begin{array}{l}\text { Se pouco se diz sobre o } \\
\text { som, quem fala sobre o } \\
\text { silêncio nos filmes? / } \\
\text { Fernando Morais da } \\
\text { Costa / 2004b. }\end{array}$ & O silêncio no cinema. & $\begin{array}{l}\text { - O silêncio como parte } \\
\text { integrante do som no } \\
\text { cinema; } \\
\text { - O espaço reservado ao } \\
\text { som na teoria e na } \\
\text { análise fílmica. }\end{array}$ & - O silêncio. & - \\
\hline Artigo & $\begin{array}{l}\text { Sobre o som no cinema de } \\
\text { horror: padrões } \\
\text { recorrentes de estilo / } \\
\text { Rodrigo Carreiro / } 2011 \mathrm{~b} \text {. }\end{array}$ & $\begin{array}{l}\text { O som no cinema de } \\
\text { horror. }\end{array}$ & $\begin{array}{l}\text { - Recursos estilísticos no } \\
\text { som no cinema de } \\
\text { horror; } \\
\text { - O som na narrativa } \\
\text { fílmica. }\end{array}$ & - O cinema de horror. & - Filmes de horror. \\
\hline Artigo & $\begin{array}{l}\text { Som, Câmera, Ação: a } \\
\text { relevância do som na } \\
\text { história do cinema / } \\
\text { Luciana Haussen / } 2008 \text {. }\end{array}$ & $\begin{array}{l}\text { A relevância do som } \\
\text { na história do } \\
\text { cinema. }\end{array}$ & $\begin{array}{l}\text { - Evolução sócio- } \\
\text { tecnológica do som no } \\
\text { cinema; } \\
\text { - O som na narrativa } \\
\text { fílmica. }\end{array}$ & $\begin{array}{l}\text { - Tecnologia do som no } \\
\text { cinema. }\end{array}$ & $\begin{array}{l}\text { - O final da década de } 20 \text { do século XX, } \\
\text { ano de } 1929 .\end{array}$ \\
\hline Artigo & $\begin{array}{l}\text { Som e ritmo interno no } \\
\text { plano-sequência / } \\
\text { Fernando Morais da } \\
\text { Costa / 2010a. }\end{array}$ & $\begin{array}{l}\text { A movimentação do } \\
\text { som dentro do plano- } \\
\text { sequência. }\end{array}$ & $\begin{array}{l}\text { - A criação de ritmos } \\
\text { distintos entre som e } \\
\text { imagem dentro de um } \\
\text { mesmo plano. }\end{array}$ & $\begin{array}{l}\text { - O plano-sequência; } \\
\text { - Som e ritmo no } \\
\text { cinema. }\end{array}$ & $\begin{array}{l}\text { - Os filmes Five (Abbas Kiarostami, 2003) } \\
\text { e Andarilho (Cao Guimarães, 2007). }\end{array}$ \\
\hline Artigo & $\begin{array}{l}\text { Sonoridades do cinema: } \\
\text { Tarkovsky e a } \\
\text { heterocronia da escuta / } \\
\text { Rodrigo Rodrigues / } 2011 .\end{array}$ & $\begin{array}{l}\text { Sonoridades do } \\
\text { cinema. }\end{array}$ & $\begin{array}{l}\text { - A simbiose entre a } \\
\text { composição musical e o } \\
\text { design sonoro. }\end{array}$ & $\begin{array}{l}\text { - Conceito de } \\
\text { endosmose; } \\
\text { - As sonoridades do } \\
\text { filme Stalker (Andrei } \\
\text { Tarkovsky, 1979); } \\
\text { - A heterocronia da } \\
\text { escuta. }\end{array}$ & $\begin{array}{l}\text { - O filme Stalker (Andrei Tarkovsky, } \\
\text { 1979). }\end{array}$ \\
\hline
\end{tabular}




\begin{tabular}{|c|c|c|c|c|c|}
\hline Artigo & $\begin{array}{l}\text { "Versão brasileira" - } \\
\text { Contribuições para uma } \\
\text { história da dublagem } \\
\text { cinematográfica no Brasil } \\
\text { nas décadas de } 1930 \text { e } \\
1940 \text { / Rafael de Luna } \\
\text { Freire / } 2011 \text {. }\end{array}$ & $\begin{array}{l}\text { História da dublagem } \\
\text { cinematográfica no } \\
\text { Brasil. }\end{array}$ & $\begin{array}{l}\text { - Experiências de } \\
\text { dublagem de filmes } \\
\text { estrangeiros para } \\
\text { exibição } \\
\text { cinematográfica no } \\
\text { Brasil; } \\
\text { - O debate que a } \\
\text { dublagem suscitava do } \\
\text { ponto de vista artístico, } \\
\text { tecnológico e } \\
\text { econômico. }\end{array}$ & $\begin{array}{l}\text { - Cinema brasileiro; } \\
\text { - Circuito exibidor } \\
\text { brasileiro; } \\
\text { - Dublagem. }\end{array}$ & $\begin{array}{l}\text { - A dublagem cinematográfica no Brasil } \\
\text { nas décadas de } 1930 \text { e } 1940 .\end{array}$ \\
\hline Artigo & $\begin{array}{l}\text { Voz e Canto Popular do } \\
\text { Negro no Cinema - } \\
\text { poética cinematográfica } \\
\text { no documentário "Adão } \\
\text { ou Somos Todos Filhos da } \\
\text { Terra" de Walter Salles e } \\
\text { Daniela Thomas / Elen } \\
\text { Döppenschmitt / 2007b. }\end{array}$ & $\begin{array}{l}\text { A voz no cinema } \\
\text { documentário. }\end{array}$ & $\begin{array}{l}\text { - A performance da voz; } \\
\text { - A oralidade nas mídias; } \\
\text { - O diálogo entre o } \\
\text { sistema oral e visual. }\end{array}$ & $\begin{array}{l}\text { - A voz no cinema; } \\
\text { - O cinema } \\
\text { documentário. }\end{array}$ & $\begin{array}{l}\text { - O documentário Adão ou Somos Todos } \\
\text { Filhos da Terra (Walter Salles e Daniella } \\
\text { Thomas, 1998). }\end{array}$ \\
\hline Artigo & $\begin{array}{l}\text { Vozes Polifônicas e } \\
\text { Escutas Musicais: a } \\
\text { articulação da banda } \\
\text { sonora em François } \\
\text { Girard / Suzana Reck } \\
\text { Miranda / } 2007 .\end{array}$ & A voz no cinema. & $\begin{array}{l}\text { - A articulação da voz e } \\
\text { da escuta no filme de } \\
\text { François Girard sobre o } \\
\text { pianista Glenn Gould. }\end{array}$ & $\begin{array}{l}\text { - Performance vocal; } \\
\text { - Voz acusmática. }\end{array}$ & $\begin{array}{l}\text { - O filme Thirty-two short films about } \\
\text { Glenn Gould (François Girard, 1993). }\end{array}$ \\
\hline Artigo & $\begin{array}{l}\text { Walter Murch: a } \\
\text { revolução da trilha sonora } \\
\text { cinematográfica / Eduardo } \\
\text { Santos Mendes / } 2006 .\end{array}$ & $\begin{array}{l}\text { As trilhas sonoras } \\
\text { realizadas por Walter } \\
\text { Murch na década de } \\
1970 .\end{array}$ & $\begin{array}{l}\text { - A importância de } \\
\text { Walter Murch na } \\
\text { mudança do pensamento } \\
\text { sonoro dos filmes norte- } \\
\text { americanos de fíç̧ão. }\end{array}$ & $\begin{array}{l}\text { - Walter Murch. } \\
\text { - Cinema norte- } \\
\text { americano. }\end{array}$ & $\begin{array}{l}\text { - Os filmes: O Poderoso Chefão (1972) e } \\
\text { Apocalise (1979), ambos do diretor } \\
\text { Frances Ford Coppola. }\end{array}$ \\
\hline
\end{tabular}

A partir desta tabela é ratificado a variedade de assuntos ou temas, subtemas, objetos e corpus específicos de estudo presentes nos livros, teses, dissertações e artigos brasileiros sobre o som no cinema. Fazendo um balanço por meio da avaliação dessas partes dos textos mencionadas, algumas divisões temáticas da pesquisa brasileira sobre o som cinematográfico podem ser decifradas. A ideia é então contemplar classificações que reunam e esclareçam essa variedade de conteúdo encontrada, desvendando vínculos entre as pesquisas. Vale destacar desde já que, com a abrangência de assuntos, temas, subtemas e objetos de estudo, há trabalhos que podem pertencer a mais de uma categoria. Portanto, todas as divisões propostas a seguir não devem ser consideradas mutuamente exclusivas. São elas: 
- História;

- Tecnologia;

- Percepção Sonora;

- Processo de Criação;

- Elementos da Trilha Sonora;

- Estudos da Voz;

- Estudos do Ruído;

- Estudos do Silêncio;

- Teoria;

- Estética e Estilo;

- Estudos de Caso.

Confira a lista bibliográfica completa distribuída por categoria estipulada no Anexo II desta dissertação.

\subsubsection{História}

A primeira temática evidente está relacionada a questões históricas. Existem pesquisas que possuem como foco principal o resgate de perspectivas sobre a história do som no cinema. As abordagens variam basicamente entre a história da inserção do som no cinema, a história do som no cinema brasileiro, a história do som no cinema de animação e a proposta de uma arqueologia da escuta.

O período do advento do som, a transição do cinema mudo para o cinema sonoro, que engloba basicamente o fim da década de 1920 e início da década de 1930, é o mais evidenciado. Neste sentido, permeando as principais tentativas e experiências de união entre som e imagem no cinema, e as teorias que se debruçaram sobre essa transição, estão os assuntos principais dos artigos "O Sonho de Edison: o advento do som sincronizado" $(\text { CARRASCO, 2003) })^{49}$, “Que papel é delegado ao som, em um meio audiovisual? A imagem preponderante, e a inserção do som no cinema" (COSTA, 2003e), e "A Inserção do Som no Cinema: percalços na passagem de um meio visual para audiovisual" (COSTA, 2003f). Aqui, vale mencionar que os manifestos clássicos "Declaração sobre o Futuro do Cinema Sonoro" de Eisenstein, Pudovkin e Alexandrov, e "The Art of Sound" de René Clair, são sempre

\footnotetext{
49 Vale mencionar que esse artigo foi retirado do capítulo homônimo da dissertação de mestrado do mesmo autor que não está aqui investigada por se tratar sobretudo de questões da trilha musical: CARRASCO, Claudiney Rodrigues. Trilha Musical: música e articulação fílmica. Dissertação (Mestrado em Cinema). USP. São Paulo, 1993.
} 
lembrados.

A década de 1970 é outro período realçado, principalmente por parte da tese "O Som no Cinema: da edição de som ao sound design - evolução tecnológica e produção brasileira" (MANZANO, 2005), que se preocupa em resgatar o desenvolvimento tecnológico sonoro e as importantes modificações na maneira da construção fílmica nesta época. Para isso, este mesmo trabalho busca historicizar a evolução do uso do som no cinema desde seu advento, no final da década de 1920, até os anos 1970, quando segundo o autor, ocorre mais uma "revolução" trazida pelo som. E ainda, a relação histórica entre as linguagens sonoras e imagéticas, e a relevância do som na história do cinema, são articulações presentes nos artigos “A Difícil Relação entre Imagem e Som no Audiovisual Contemporânea" (BELLEBONI, 2004), e "Som, Câmera, Ação: a relevância do som na história do cinema" (HAUSSEN, 2008), respectivamente.

Já a história do som no cinema brasileiro começa a ser investigada. O livro "O Som no Cinema Brasileiro" (COSTA, 2008), e a tese do mesmo autor "O som no cinema brasileiro: revisão de uma importância indeferida" (COSTA, 2006a), base do livro, são dois grandes exemplos disso. As primeiras tentativas de sincronização entre som e imagem no país, entre 1902 e 1911; a transição para o cinema sonoro no fim da década de 1920 e meados de 1930; as mudanças relacionadas com a chegada dos primeiros gravadores de som portátil no início da década de 1960; e a dicotomia entre a excelência técnica alcançada e a evolução da estética sonora dos filmes nacionais a partir dos anos 1990, são períodos aprofundados nesta obra. As primeiras tentativas de sincronização de som e imagem no Brasil ainda são reforçadas pelo artigo, do mesmo autor, intitulado "Primeiras tentativas de sonorização no cinema brasileiro (os cinematógrafos falantes 1902-1908)" (COSTA, 2006b). Bem como, o contexto da introdução da técnica de gravação de som sincrônico com equipamento leve, no início da década de 1960, a partir da pesquisa da dissertação “A Introdução do Som Direto no Cinema Documentário Brasileiro na Década de 1960" (GUIMARÃES, 2008).

Outra retrospectiva nacional abrangente se dá ainda na tese de Luiz Adelmo Manzano (2005), que resgata a evolução sonora do cinema brasileiro, principalmente na área da pósprodução de som, até meados da década de 2000. Todos esses trabalhos contribuem diretamente para uma melhor compreensão da história da produção sonora cinematográfica no Brasil e, consequentemente, uma maior conscientização da importância do som no cinema nacional. Vale acrescentar inclusive que, tanto as pesquisas de Luiz Adelmo Manzano (2005), quanto a de Tide Borges Guimarães (2008), possuem entrevistas realizadas com profissionais da área as quais são um material valioso de recuperação de informações históricas até antes 
não documentadas. Luiz Adelmo entrevista os profissionais: José Luiz Sasso, Mauro Alice, Virginia Flores, Roberto Ferraz, Michel Ruman, Giba Assis Brasil, Eduardo Santos Mendes e Miriam Biderman. E Tide Borges: Juarez Dagoberto, Miguel Sagatio, Geraldo José, Walter Goulart, Mário Carneiro, Arnaldo Carrilho, Eduardo Escorel, Dib Lutfi, Arnaldo Jabor, Luiz Carlos Saldanha, Nelson Pereira dos Santos e Thomaz Farkas.

A experiência de dublagem de filmes estrangeiros para exibição no Brasil nas décadas de 1930 e 1940 também é analisada historicamente pelo artigo “'Versão brasileira' Contribuições para uma história da dublagem cinematográfica no Brasil nas décadas de 1930 e 1940" (FREIRE, 2011). É evidenciado o debate que a dublagem provocava do ponto de vista artístico, tecnológico e econômico no circuito exibidor e no cinema brasileiro da época.

Há ainda o caso do artigo "A Nova Sonoridade do Cinema em São Paulo" (GATTI; MENDES, 2008), que a princípio tem a intenção de discorrer sobre o som do cinema paulistano na retomada de produção nos anos 1990. Na verdade, este material é uma transcrição de uma palestra de Eduardo Santos Mendes, mediada pelo professor e pesquisador André Gatti. A maior parte do conteúdo do texto é direcionado para a historia da técnica, da estética e da evolução do campo profissional na área. Eduardo Santos Mendes utilizou-se dessas abordagens para contextualizar a história do som no cinema, e a partir daí adentrar no universo brasileiro. Logo, discorre brevemente sobre a recorrência do som direto no país, e também sobre a evolução técnica e estética do som no cinema nacional.

A história do cinema de animação também começa a ser contada, tanto pela tese "Movimentos Invisíveis: a estética sonora do cinema de animação" (WERNECK, 2010) quanto pela dissertação "A Relação Som-Imagem nos Filmes de Animação Norte-Americanos no Final da Década de 1920: do silencioso ao sonoro" (BARBOSA, 2009). A primeira resgata a história do desenvolvimento do som como linguagem no cinema de animação, discorrendo também sobre a evolução técnica e tecnológica do aparato sonoro principalmente nos primeiros anos do cinema e no período de desenvolvimento da animação nos anos pós Segunda Guerra. Já a segunda foca na história do processo de produção do cinema de animação e do processo de criação de suas trilhas sonoras no período final do cinema silencioso e no início do cinema sonoro. Ambos trabalhos ganham destaque por serem os primeiros em língua portuguesa que contemplam esse gênero cinematográfico.

Existe também um caso ímpar presente neste grupo relacionado à reformulação da história do cinema sonoro anunciada através da arqueologia da escuta, proposta na dissertação "Introdução à Arqueologia da Escuta ou o Nascimento do Cinema Sonoro a partir do Espírito da Ópera" (CAPELLER, 2005) que situa as relações históricas do cinema com o som, 
traçando a origem do som como "objeto" e decifrando os momentos de ruptura nos padrões de escuta da cultura ocidental. Parte desta dissertação foi publicada posteriormente em um artigo intitulado "Introdução à Arqueologia da Escuta: do som e da voz como objetos de enunciação" (CAPELLER, 2011).

Estas são, portanto, as pesquisas que possuem como foco principal o resgate de perspectivas históricas do som no cinema, contabilizando o total de um livro, três teses, três dissertações e nove artigos. Mas é curioso notar que o resgate de perspectivas históricas é uma atividade recorrente também em outros trabalhos que não estão aqui diretamente classificados por não terem essencialmente essa abordagem como cerne principal de pesquisa, mas a utilizam muitas vezes para descrever uma conjuntura do assunto central pretendido. Desta forma, julga-se importante para complementar esta seção, uma exposição rápida dos conteúdos mais relevantes referentes à história do som no cinema presentes em outros materiais encontrados.

Assim, a investigação do uso do som tanto no início do cinema, período conhecido como mudo, quanto no começo do cinema sonoro, onde a ênfase está na contextualização da produção cinematográfica alemã dos primórdios até o ano de 1931, pode ser encontrada no livro "Som-imagem no cinema: a experiência alemã de Fritz Lang" (MANZANO, 2003). O resgate de aparatos tecnológicos e procedimentos variados que ajudaram no processo que culminou com a inclusão do som nos filmes está também presente em fragmentos da dissertação "Som no Cinema, Silêncio nos Filmes: o inexplorado e o inaudito" (COSTA, 2003a). Uma aproximação histórica sobre a incorporação do som no sistema de representação do cinema clássico norte-americano, a situação empresarial desse período, as mudanças de procedimento de realização dos filmes, e mesmo sobre o desenvolvimento de tecnologia específica para as necessidades da realização cinematográfica com som direto nesta fase de transição do cinema mudo para o sonoro, é encontrada na tese "Procedimentos de trabalho na captação de som direto nos longas-metragens brasileiros Contra Todos e Antônia: a técnica e o espaço criativo" (SOUZA, 2011). O estudo de um caso mais específico, sobre a maneira como ocorreu a chegada do som às salas de cinema da cidade de Campinas, no estado de São Paulo, está presente no artigo "O Artista Silencioso: um estudo da construção sonora no filme do Cineclube Universitário de Campinas" (ALMEIDA, 2011). O resgate de modelos de exibição e percepção da experiência cinematográfica nas primeiras décadas do século XX, de métodos de acompanhamento sonoro nesse período ${ }^{50}$, e de informações sobre a revolução

50 O resgate de modelos de exibição e percepção da experiência cinematográfica nas primeiras décadas do século XX e de métodos de acompanhamento sonoro nesse período, também pode ser conferido de forma mais sucinta no artigo "Pré-escutas: modelos de audibilidades dos primeiros cinemas" (CASTANHEIRA, 
eletrônica do som nos anos 1950, 1960 e 1970, pode ser constatado na dissertação "A Paisagem Sonora Eletrônica: a construção de novas audibilidades no cinema" (CASTANHEIRA, 2010a). Bem como, de forma mais resumida, no artigo do mesmo pesquisador, denominado "Pré-escutas: modelos de audibilidades dos primeiros cinemas" (CASTANHEIRA, 2009a). Um breve histórico da tecnologia e suas influências no cinema sonoro também pode ser encontrado na dissertação "A Percepção Sonora no Cinema: ver com os ouvidos, ouvir com outros sentidos" (CARVALHO, 2009). E a história da tecnologia e do uso dos sistemas de reprodução sonora no cinema, pode ser conferida de forma mais aprofundada nas dissertações "A Estereofonia Digital: Uma abordagem sobre a técnica, o padrão e a linguagem sonora cinematográfica norte-americana no período de 1991 a 2001" (ALVAREZ, 2007) e "O Surround e a Espacialidade Sonora no Cinema” (COSTA, 2004a).

Ainda que o período da transição do cinema mudo para o cinema sonoro seja o momento histórico mais estudado, a categoria História consegue abranger conteúdos importantes acerca de processos e fatos necessários para a melhor compreensão do som cinematográfico como um todo. É interessante notar que, intrínseco a essas questões históricas abordadas pelos trabalhos, está a associação tanto com a evolução tecnológica do som no cinema, quanto ao desenvolvimento da linguagem sonora nos filmes. Ou seja, há uma conscientização da importância do progresso da tecnologia para a arte cinematográfica, além da reflexão sobre como se deu o uso dos elementos sonoros na narrativa fílmica ao longo dos anos. Vale destacar o quanto a história do som no cinema brasileiro tem sido estudada, e o início de uma preocupação em desvendar a história do som no cinema de animação. E mais, propostas como a de reformulação da história do cinema sonoro anunciada através da arqueologia da escuta, por exemplo, e de certa forma, todas as análises históricas aqui mencionadas, contribuem para enriquecer a importância constitutiva do som em incitar outros modelos de se escrever a história do cinema. Como afirma Rick Altman, um dos maiores historiadores do som no cinema:

Hoje estamos começando a entender a necessidade de nada menos do que uma redefinição de toda a história do cinema, com base em novos objetos e novos projetos. A única maneira de promover tal revolução é a de inspecionar o maior número possível de objetos, com uma vontade de questionar seus próprios nomes e identidades, juntamente com os contextos nos quais aprendemos a compreendê-los. [...] Para um universo de estudos de cinema cada vez mais profissionalizado, onde a maioria dos casos já há muito tempo foram experimentados e julgados, o som precisa ser chamado como uma nova testemunha, pois oferece novas evidências, forçando, assim, a abertura de antigos dossiers. Com o som, é concedido uma nova audiência para o cinema. ${ }^{51}$ (ALTMAN, 2004: 7)

2009a).

51 Tradução do autor. 


\subsubsection{Tecnologia}

Tecnologia é mais uma temática evidenciada. Concentrando a princípio nos trabalhos que priorizam essencialmente aspectos tecnológicos como foco central de estudo, tem-se apenas três trabalhos aqui agrupadas, sendo duas dissertações e um artigo. Já antecipando uma semelhança entre essas pesquisas, todas possuem a mesma preferência de enfoque: os sistemas de reprodução sonora no cinema.

A tecnologia dos sistemas monofônicos (Vitaphone, Movietone e Photophone), estereofônicos (RCA Panoramic "Fantasound", Cinerama, Cinemascope, Todd-AO, Sensurround e Dolby Stereo) e digitais (Kodak CDS, Dolby Digital, DTS e Sony SDDS), é a base de discussão da dissertação "A Estereofonia Digital: uma abordagem sobre a técnica, o padrão e a linguagem sonora cinematográfica norte-americana no período de 1991 a 2001" (ALVAREZ, 2007). Esta pesquisa de mestrado visa compreender essas tecnologias tanto por um viés técnico, quanto como uma nova possibilidade de linguagem, investigando o uso do espaço sonoro em filmes norte-americanos.

A descrição técnica de formatos de som estereofônico no cinema também é o foco da dissertação "O Surround e a Espacialidade Sonora no Cinema" (COSTA, 2004a), que aborda tanto as primeiras experiências de som multicanal com o som magnético, quanto os principais formatos digitais. Incluindo a tecnologia THX, o trabalho apresenta ainda uma comparação dos formatos e suas aplicações em diferentes mídias.

E a tecnologia de espacialização surround 5.1 é o assunto do artigo "O Som Surround e Suas Formas de Uso" (PEDREIRAS, 2008), que delineia o funcionamento desse modelo de reprodução de som e suas técnicas de mixagem, apoiando-se apenas no sistema Dolby Digital.

Estes são portanto, os únicos trabalhos encontrados que possuem como foco central de estudo aspectos tecnológicos do som no cinema, os quais se resumem à tecnologia estereofônica digital. Todavia, ao avaliar as demais bibliografias levantadas, é fácil encontrar em parte dos documentos, elucidações acerca da tecnologia do som no cinema, como por exemplo na categoria anterior, onde é observado uma certa recorrência do resgate tecnológico para uma argumentação historiográfica do som no cinema. Essa afinidade entre história e tecnologia do som no cinema inclusive pode também vir a esclarecer o por quê da pesquisadora Cláudia Gorbman ter associado essas temáticas em seus dois levantamentos bibliográficos. Em Bibliography on Sound in Film (1980) GORBMAN criou a seção "Tecnologia", subdividida em duas vertentes: "Geral" e "História - a chegada do som"; e em Annotated Bibliography (1985), além da seção individual "Tecnologia em geral", a 
pesquisadora concebe o tópico "História: estilo e tecnologia". Neste sentido, abordagens sobre, por exemplo, a evolução tecnológica do som no cinema e sobre as principais experiências de união entre som e imagem nos primórdios do cinema, já mencionadas no tópico História como fragmentos de alguns trabalhos, podem de certa forma complementar esta seção. Em especial, o conteúdo de parte da tese "Procedimentos de trabalho na captação de som direto nos longas-metragens brasileiros Contra Todos e Antônia: a técnica e o espaço criativo" (SOUZA, 2011), que também pode agregar informações precisas sobre os principais avanços tecnológicos voltados para a gravação do som direto, como por exemplo, os sistemas de som no disco (sound-on-disc system) e no filme (sound-on-film system), incluindo o registro sonoro magnético, gravadores de som portáteis, microfones "sem fio", tecnologia digital portátil multipista, etc.

Observa-se ainda uma aproximação do campo da tecnologia do som no cinema com pesquisas no âmbito da percepção da experiência cinematográfica. Por exemplo, o resgate de tecnologias de síntese sonora e de demais componentes da intitulada "revolução eletrônica" do som nos anos 1950, 1960 e 1970, até chegar novamente na evolução dos dispositivos estereofônicos de reprodução do som, pode ser encontrado na dissertação "A Paisagem Sonora Eletrônica: a construção de novas audibilidades no cinema" (CASTANHEIRA, 2010a). Bem como, de forma mais resumida, no artigo proveniente dessa mesma pesquisa, "O Som Expandido: os novos espaços do som no cinema" (CASTANHEIRA, 2011b).

O cinema é uma arte estritamente tecnológica e continua em constante transformação por conta da evolução deste aparato, bastando notar por exemplo, dois assuntos em evidência no meio atualmente: a questão dos padrões de loudness ${ }^{52}$ e da transição da projeção para o digita $^{53}$. Logo, na esperança de expandir as abordagens e buscar outras pesquisas com focos de análise que não somente o dos sistemas de reprodução sonora no cinema aqui recorrentes, foram também consultados os Anais do Congresso Brasileiro de Engenharia de Áudio da AES Brasil $^{54}$. Entretanto, a busca não obteve êxito. Nas publicações da Audio Engineering Society norte-americana, fundada em 1948, e responsável pelo desenvolvimento de padrões

52 A questão do loudness está relacionada à percepção do espectador em relação à intensidade do som. Na prática audiovisual implica na diferença de "volume" encontrada entre os conteúdos dos canais de televisão (programas de TV, filmes, comerciais, etc.), e entre os próprios canais em si. No ano de 2013 foi sancionada uma lei que teoricamente regulamenta a padronização desses volumes de áudio, mas na prática ainda há muitas discussões a respeito desses padrões e da aplicação das penalidades da lei.

53 A transição da projeção para o digital foi tema da mesa "Cinema Digital - Desafios e Perspectivas: panorama do estágio atual do processo de digitalização do parque exibidor brasileiro" na Semana ABC 2013, evento anual da Associação Brasileira de Cinematografia. Para mais informações, assista o debate na íntegra pelo link: $<$ http://www.youtube.com/watch?feature=player_embedded\&v=COJl23XxAiY $>$. Acesso em 30 de maio de 2013.

54 Versão brasileira da conceituada sociedade profissional dedicada exclusivamente à tecnologia do áudio na área de engenharia de áudio, tecnologias de comunicações e engenharia acústica: Audio Engineering Society. 
industriais e recomendações técnicas de áudio, existem diversos documentos relacionados à tecnologia do som no cinema. Mas os anais do principal evento científico de engenharia de áudio no Brasil são bem mais recentes, tendo sua primeira edição publicada em 2003, e infelizmente ainda não possuem artigos em língua portuguesa que contemplem especificamente a área cinematográfica. Até existem trabalhos que podem dialogar de certa forma com a prática de mixagem e restauração do som no cinema, desvendando por exemplo, técnicas de remoção de interferências de fundo em sinais de áudio a partir de plugin $\mathrm{VST}^{55}$, mas por não as aplicarem diretamente ao cinema, não estão aqui abrangidos.

Em tempos onde a evolução tecnológica e suas interferências na sociedade se expandem cada vez mais rápido, é natural que o universo cinematográfico também seja afetado. Portanto, a temática acerca da tecnologia é de extrema importância para refletir, compreender e acompanhar todas as nuances técnicas dessas transformações, principalmente por estas estarem também conectadas diretamente ao desenvolvimento da linguagem, de padrões e formatos de produção, de mercado, de realização, de exibição, etc.

\subsubsection{Percepção Sonora}

Uma terceira classificação que não deixa de relacionar com questões da evolução histórica e tecnológica, se refere à percepção sonora no cinema. Aqui, deve-se fazer uma ressalva: a escolha do termo Percepção Sonora pode parecer ir na contramão dos conceitos de "audiovisão" e "contrato audiovisual", tão difundidos por Michel Chion para descrever a maneira pela qual é dada a percepção da experiência cinematográfica. Para CHION (2011), autor desses conceitos, a percepção conjunta dos elementos imagéticos e sonoros no cinema se dá de forma diferente da percepção de cada elemento considerado isoladamente.

Trata-se de uma atividade que, estranhamente, nunca é considerada na sua novidade: continua-se a dizer «ver» um filme ou um programa, ignorando a modificação introduzida pela banda sonora. Ou então, contentamo-nos com um esquema aditivo. Assistir a um espetáculo audiovisual equivaleria, em suma, a ver imagens $e$ a ouvir sons, mantendo-se cada percepção perfeitamente isolada. [...] no contrato audiovisual, uma percepção influencia a outra e a transforma: não «vemos» a mesma coisa quando ouvimos; não «ouvimos» a mesma coisa quando vemos. [...] ao descrever e formular a relação audiovisual como contrato (ou seja, como o oposto de uma relação natural que remete para uma harmonia preexistente entre as percepções), esboça um método de observação e de análise suscetível de ser aplicado aos filmes, aos programas de televisão, aos vídeos, etc., e resultante de numerosas intervenções pedagógicas. (CHION, 2011, p. 7)

55 A referência do exemplo citado é: TYGEL, Alan Freihof; BISCAINHO, Luiz Wagner P.. Plugin VST para Remoção de Ruído de Fundo. In: Congresso de Engenharia de Áudio da AES-Brasil, 2007. Anais do 50 Congresso de Engenharia de Áudio. São Paulo, 2007. 
Porém, a opção por utilizar a expressão Percepção Sonora foi escolhida diante da presença de trabalhos que articulam assuntos sobre audibilidades e modelos de escuta no cinema, o que autentica o termo e a categoria.

Para analisar o surgimento de novas audibilidades no cinema, a dissertação "A Paisagem Sonora Eletrônica: a construção de novas audibilidades no cinema" (CASTANHEIRA, 2010a), destaca o som eletrônico na experiência cinematográfica como ferramenta fundamental na reconfiguração de novos espaços repletos de estímulos, e que aguça a relação sensorial do espectador com a matéria fílmica, tanto no campo de significações quanto no campo acústico e auditivo. Inicialmente, explora o mecanismo do cinema a partir da fenomenologia, das teorias das materialidades e das ciências cognitivas. A partir de então, com uma estrutura embasada no som eletrônico, no ambiente tecnológico e na evolução dos dispositivos de imersão cinematográfica, a pesquisa expande para uma complexa articulação entre as relações sócio-culturais humanas, os estímulos mundanos, e as dimensões de percepção e de produção de sentidos. E ainda, atrelado ao estudo psicoacústico dos "objetos sonoros" de Pierre Schaeffer - retomados posteriormente por Michel Chion -, reconfigura o conceito de "paisagem sonora" de Murray Schafer a partir da proposta de uma "revolução eletrônica" do som desenvolvida ao longo dos anos 1950, 1960 e 1970.

O conteúdo desta dissertação pode ser encontrado também distribuído em outros seis artigos publicados do mesmo autor, cada um compilando parte dessa participação do som e da escuta na experiência cinematográfica. São eles: "A Paisagem Sonora Eletrônica: a reconstrução do mundo sonoro contemporâneo no cinema" (2008a) focando na teoria das materialidades, na investigação do ambiente sonoro e das formas de cognição beneficiadas com o uso de sons criados ou modificados eletronicamente; “A Presença do Som: proposta para uma investigação material da experiência sonora no cinema" (2009b) relacionando os conceitos de redução fenomenológica de Husserl e a escuta reduzida de Schaeffer para investigar a importância do som na afetação do corpo imerso no dispositivo cinematográfico; "Electronic Tonalities: o espaço eletrônico e a impressão de realidade na ficção científica" (2008b) discutindo a participação do som eletrônico na construção da impressão de realidade no cinema; "O Som Eletrônico no Cinema: uma abordagem fenomenológica" (2010b) pensando as relações entre o corpo e o espaço sonoro que se configura a partir do som eletrônico no cinema; "O Som Expandido: os novos espaços do som no cinema” (2011b) também discorrendo sobre novas audibilidades e modelos perceptivos no cinema; e "Pré- 
escutas: modelos de audibilidades dos primeiros cinemas" (2009a) sobre a construção dos códigos narrativos do cinema e sua relação com a prática sonora e os modelos de audibilidades dos primeiros cinemas.

A audição também é privilegiada na dissertação "A Percepção Sonora no Cinema: ver com os ouvidos, ouvir com outros sentidos" (CARVALHO, 2009). O estudo da percepção, da escuta e do espaço sonoro é utilizado para ampliar a compreensão da utilização do som na construção da narrativa fílmica. Partindo da reflexão sobre a função do som no mundo, nas situações cotidianas, a pesquisa estende-se da fisiologia da audição ao desenvolvimento da memória auditiva humana e as mudanças acústicas sofridas durante os últimos séculos. Sendo um dos objetivos despertar o interesse para as potencialidades do sistema auditivo, as capacidades perceptivas e uma escuta mais atenta, buscando sempre uma relação entre essas percepções e o uso do som nos filmes. Assim, além de dissertar sobre os pontos e as diferentes atitudes de escuta, são elaborados três novos tipos de escutas: a equiparada, a surda e a convergente. E mais, a discussão sobre os espaços sonoros traz possíveis localizações espaciais do som no cinema, estilos de sonorização de filmes e a relação entre espectador e filme, a qual é ilustrada com uma pesquisa empírica: uma entrevista realizada logo após uma sessão do filme A Ostra e o Vento (Walter Lima Jr., 1997) com um grupo de cinco pessoas, utilizada para demonstrar algumas diferenciações de sentido quando a questão referida é a percepção auditiva.

Para a valorização do potencial do uso do som nos filmes, as formas de recepção do som no cinema são também o foco de estudo de mais uma dissertação: "O Cinema, uma arte sonora" (FLORES, 2006). Para discursar sobre critérios ligados à questão da escuta e da matéria sonora após uma contextualização sobre a autenticidade do som na teoria de cinema e da música, a pesquisa beneficia-se da morfologia dos sons proposta por Pierre Schaeffer em seu Traité des Objets Musicaux ${ }^{56}$. Deste modo, a questão do espaço sonoro e de como ele é explorado no cinema, transita por diferentes formas e maneiras com que os sons podem ser usados nos filmes. Reunindo as características dos tipos de escutas estudadas, a pesquisa finaliza refletindo sobre a apreciação do som nos filmes a partir da escuta fílmica, e analisa a trilha sonora de trechos dos filmes Blow Up (Michelangelo Antonioni, 1967), Um tiro na noite (Brian de Palma, 1981) e O Pântano (Lucrecia Martel, 2001). Desta dissertação também resultou a publicação do artigo "A Escuta Fílmica: uma atitude estética” (FLORES, 2007), réplica do item homônimo da dissertação.

Um foco mais específico é encontrado no artigo "Escutar tanto quanto se vê (como um

56 SCHAEFFER, Pierre. Traité des objets Musicaux. Paris: Editions du Seuil, 1966. 
filme iraniano, sobre uma criança cega, pode ensinar a ouvir?)" (COSTA, 2003b), o qual demonstra a importância da audição na infância com base no filme O Silêncio (Mohsen Makhmalbaf, 1998) e discute, em contraponto, a primazia da visão na sociedade ocidental.

Fora estes três trabalhos de mestrado e os oito artigos mencionados que dialogam diretamente com a questão da percepção sonora no cinema e que consequentemente estão aqui agrupados, duas pesquisas classificadas em outras seções também merecem ser citadas de forma complementar. A primeira é a dissertação "Introdução à Arqueologia da Escuta ou o Nascimento do Cinema Sonoro a partir do Espírito da Ópera" (CAPELLER, 2005), já classificada na seção História, e que propõe uma melhor compreensão do cinema a partir das bases de uma arqueologia dedicada à escuta. Desta forma, resgata transformações históricas do campo do audível, investigando as tipologias da escuta de Pierre Schaeffer, de Theodor W. Adorno e de Michel Chion, tentando "desembaraçar" a historicidade da escuta da história da música, e inserir o cinema como um dispositivo audiovisual de simulação da própria escuta. A segunda, também uma dissertação, é a intitulada "Entre a Escuta e a Visão: o lugar do espectador na obra de Robert Bresson" (ASPAHAN, 2008) e que, como será visto, está classificada na seção Estudos de Caso por priorizar o estudo da obra do cineasta francês Robert Bresson exclusivamente. No que tange à parte da escuta, este trabalho também apoiase no pensamento de Pierre Schaeffer e Michel Chion para compreender as implicações da composição sonora na sua relação com a escuta no filme Um condenado à morte escapou ou O vento sopra onde quer (Robert Bresson, 1956). E ainda, analisa a variação entre as atitudes de escuta do espectador e as atitudes de escuta do personagem nesse filme que, logo, exige do espectador uma atenção especial aos sons.

Observa-se assim, que grande parte dos trabalhos atrelados à percepção sonora no cinema utiliza da teoria da música eletroacústica como base de articulação teórica, onde a pesquisa do compositor e pesquisador francês Pierre Schaeffer torna-se referência fundamental, bem como a de seu discípulo Michel Chion. Conceitos do pesquisador canadense Murray Schafer, como o de "paisagem sonora", completam a lista de influências mais citadas neste grupo. Atrelada à multifacetada percepção da experiência cinematográfica, a Percepção Sonora torna-se então mais uma temática evidente, despertando, estimulando e participando na formação de uma consciência auditiva do espectador. 


\subsubsection{Processos de Criação}

Com a existência de documentos voltados para a pesquisa da prática de realização cinematográfica, outra seção que pode ser indicada é a denominada Processos de Criação. Nela estão classificados os materiais que prioritariamente buscam conhecer e descrever os processos e métodos de trabalho com som no cinema.

A prática de trabalho na captação de som direto é minuciosamente investigada na tese "Procedimentos de trabalho na captação de som direto nos longas-metragens brasileiros Contra Todos e Antônia: a técnica e o espaço criativo" (SOUZA, 2011). Partindo de uma aproximação histórica sobre o contexto da incorporação do som no sistema de representação do cinema clássico norte-americano, a pesquisa detalha as atividades práticas executadas pelo técnico de som direto no âmbito da produção cinematográfica ficcional, como por exemplo, abordando as configurações técnicas, a constituição da equipe, a definição de estratégias na pré-produção e na filmagem, a rotina de trabalho do som direto no set, a monitoração do som, as relações entre as demais áreas técnicas de realização, etc. E ainda, ao analisar os procedimentos empregados no registro sonoro sincrônico dos filmes Contra Todos (Roberto Moreira, 2004) e Antônia (Tata Amaral, 2006), demonstra o dinamismo do método de trabalho, as demandas específicas impostas pelos filmes e a atuação do técnico de som direto no planejamento dos procedimentos referentes ao desenvolvimento de soluções adequadas às necessidades específicas de cada projeto. Esta tese, além de relatar a experiência profissional do próprio autor que é responsável pelo som direto dos filmes indicados, pode ser considerada a mais completa e esclarecedora bibliografia publicada em língua portuguesa até o momento acerca da prática de trabalho com o som direto no cinema de ficção.

Já abordando diferentes fases do processo de inserção do som fílmico, a análise dos procedimentos de criação e realização da trilha sonora nas diversas etapas de produção cinematográfica do filme Ensaio Sobre a Cegueira (Fernando Meirelles, 2008), é a base da dissertação "Se Podes Ouvir, Escuta: a gênese audiovisual de Ensaio Sobre a Cegueira" (PEREIRA, 2010). Para tanto, a pesquisa considera o livro de José Saramago que deu origem à adaptação audiovisual, a versão do roteiro utilizada para a filmagem, o primeiro e o sétimo corte da montagem, a sessão de mixagem antes de ser enviada ao Festival de Cannes, e a versão final do filme apresentada comercialmente nas salas de cinema. Desta forma, o estudo parte das relações entre som e imagem desde a pré-produção, articulando também as técnicas e os métodos utilizados ao longo do percurso de trabalho com o som direto, a montagem, a composição musical, a edição de som e a mixagem. Assim, a elaboração e a execução do 
conceito sonoro desse filme em específico, é apresentada de forma a contemplar todos os passos de sua construção audiovisual, demonstrando o quanto um pensamento sonoro inerente desde o início do projeto favorece uma qualidade técnica e estética do produto final. Como forma de divulgar os resultados parciais dessa pesquisa de mestrado, foi ainda publicado o artigo "Se Podes Ouvir, Escuta: relações audiovisuais do filme Ensaio Sobre a Cegueira e considerações sobre seu processo criativo" (PEREIRA, 2009a).

A prática de trabalho na pós-produção de som especificamente também é alvo de pesquisa. A dissertação "Análise do design sonoro no longa-metragem Ensaio Sobre a Cegueira" (OPOLSKI, 2009a) fornece informações detalhadas sobre as principais funções e procedimentos realizados no processo de edição de som, de mixagem e de concepção do design sonoro $^{57}$ de filmes de ficção. Como pode ser notado pelo título, essa pesquisa também trabalha sobre o filme Ensaio Sobre a Cegueira (Fernando Meirelles, 2008), porém relata e discute prioritariamente os métodos de criação sonora na etapa de finalização de som da obra, explicando a prática de trabalho e a relação entre os profissionais envolvidos, e verificando que a recriação do som na pós-produção influencia dramática e narrativamente a obra audiovisual. Vale destacar que a autora fez parte da equipe de edição de som do filme apontado, e inclusive, nota-se que essa pesquisa é uma grande referência bibliográfica da dissertação de PEREIRA (2010) há pouco citada.

De forma correspondente, o estudo do processo de pós-produção de som para cinema é o interesse da dissertação "Criando Mundo com Sons: pós-produção de som e sound design no cinema" (ESPOSITO, 2011), que elucida a metodologia de trabalho usada pelo cinema norte-americano, relatando o termo "sound designer" criado por Walter Murch e investigando a trajetória do supervisor de edição de som e mixador brasileiro Alessandro Laroca, cuja inspiração de método de trabalho vem da estrutura hollywoodiana. A pesquisa ainda analisa a trilha sonora da primeira sequência do filme Tropa de Elite 2 (José Padilha, 2010). Neste caso, tanto a dissertações de Kira Pereira (2010), quanto a de Débora Opolski (2009a), são referências bibliográficas bastante citadas, uma vez que possuem como elo a presença de Alessandro Laroca como supervisor de edição de som dos filmes estudados. Ligação esta que se estende ao conteúdo do artigo "Produção Sonora no Cinema Contemporâneo: um olhar sobre desafios do som no cinema brasileiro e o processo de finalização de som do filme Tropa de Elite 2" (ALVES, 2011), que apresenta e também analisa o processo de criação na edição de som e mixagem do filme Tropa de Elite 2, além de refletir sobre complicados desafios

57 Uma curiosidade: o termo comumente utilizado hoje nos créditos dos filmes para designar o que OPOLSKI (2009a) chama de "design sonoro" é "desenho de som". 
enfrentados pela produção sonora no cinema brasileiro contemporâneo.

Vale destacar que as três dissertações citadas, a de Débora Opolski, Kira Pereira e de Mauricio Esposito, possuem glossários ${ }^{58}$ explicando termos técnicos utilizados no "dia a dia" dos profissionais de som cinematográfico, o que é importante para esclarecer e expandir o vocabulário da área.

Outros três artigos que discursam sobre o processo de trabalho são: "Escutando o Cinema" (LEME, 2008), "As ideias da trilha sonora do filme Akira" (BOZICANIN, 2008) e "Diálogos sobre a imagem visual e a imagem sonora: a experiência de escritura do sonoro nos documentários etnográficos" (VEDANA, 2011). O primeiro discorre de forma bem genérica sobre os elementos, as etapas e o trabalho com a produção sonora cinematográfica. O segundo aborda a metodologia de produção do filme de animação Akira (Katsuhiro Ôtomo, 1988), evidenciando a técnica de prescoring utilizada para o sincronismo labial, o processo e as ferramentas de construção da trilha sonora, e demonstrando o quanto o som colabora para a trama do filme. E o terceiro, apresenta a experiência na etapa de montagem de documentários etnográficos, refletindo sobre a presença do som na elaboração da narrativa fílmica, as escolhas de decupagem, e a relação audiovisual na produção documental do Banco de Imagens e Efeitos Visuais da UFRGS (Biev) ${ }^{59}$, concentrando no som como imagem simbólica e em sua capacidade de narrar histórias.

Como adendo, além da tese, das três dissertações e dos cinco artigos aqui alocados, um material complementar a este grupo é parte da pesquisa de mestrado "A Experiência do Cinema de Lucrecia Martel: resíduos do tempo e sons à beira da piscina" (BARRENHA, 2011), que elucida o processo de criação e produção da diretora argentina Lucrecia Martel, demonstrando como a cineasta trabalha com a matéria sonora em seus filmes de forma singular, partindo de sonoridades ou estímulos sonoros como pressupostos para a elaboração tanto do roteiro, quanto da mise en scène de suas obras.

Conforme percebido, os documentos reunidos nessa temática contemplam as etapas centrais de concepção sonora no cinema, expondo o trabalho com o som desde o roteiro, na pré-produção, até a pós-produção, articulando assim, práticas de som direto, montagem, edição de som e mixagem. Desta forma, tornam-se materiais didáticos importantes no auxílio da compreensão de procedimentos de trabalho com o som, facilitando o aprendizado e,

58 A tese de MANZANO (2005) também possui um glossário com termos técnicos bem explicativo.

59 O Biev é um projeto pertencente ao Núcleo de Estudos sobre Culturas Contemporâneas (NUPECs), do Programa de Pós-Graduação em Antropologia Social da Universidade Federal do Rio Grande do Sul (UFRGS). Uma curiosidade: no Biev existe o Grupo de Trabalho sobre Etnografia Sonora coordenado por Viviane Vedana, e que engloba estudos etnográficos em antropologia visual e sonora em sociedades complexas. 
consequentemente, aprimorando o processo de formação de novos profissionais na área. Além disso, contribuem para a disseminação de práticas que favorecem o uso da potencialidade sonora nos filmes, reforçando a importância do som na construção da narrativa fílmica. Observa-se também que há a predominância de um método de trabalho explorado em relação à pós-produção. Quatro pesquisas (três dissertações e um artigo) estudam obras onde o profissional Alessandro Laroca e sua equipe são quem desenvolvem o "desenho de som". Aproveitando disso, essas pesquisas acabam interagindo de forma mais próxima ao ponto de intercambiarem informações umas das outras para enriquecer o conteúdo estudado. Por fim, mesmo que estudando casos particulares, dois artigos contribuem para expandir conhecimentos de trabalho em outros gêneros que não só o da ficção, como o de cinema de animação e o de documentários etnográficos.

\subsubsection{Elementos da Trilha Sonora}

Os elementos formadores da trilha sonora também recebem atenção especial de forma mais distinta em algumas bibliografias coletadas. Neste caso, referindo-se a pesquisas que privilegiam o estudo da voz, dos ruídos e do silêncio no cinema. Apenas a música que, apesar de componente solene da trilha sonora, não corresponde ao interesse de investigação prédefinido nesta dissertação ${ }^{60} \mathrm{e}$, portanto, não possui uma categoria individual para si. Porém, antes de especificar os estudos dos elementos isoladamente, nota-se um grupo de materiais cujo propósito central é a apresentação de classificações para a linguagem do som cinematográfico.

Neste grupo estão uma dissertação e três artigos. A dissertação, intitulada "Sonologia e Cinema: elementos para análise áudio-visual” (BRÄUTIGAM, 2007), testa a aplicabilidade da tipomorfologia de Pierre Schaeffer no auxílio da descrição dos elementos sonoros no cinema, complementando com estudos dos compositores e teóricos Denis Smalley, Trevor Wishart e Michel Chion. Para empregar o ferramental trazido da música eletroacústica na análise fílmica, concentrando-se nas propriedades dos sons, a pesquisa busca também relações entre o elemento visual e a narrativa de filmes. O trabalho utiliza-se de uma classificação primária dos componentes da trilha sonora em música, ruídos, cenografia sonora ${ }^{61}$ e palavra.

60 Reiterando: devido à necessidade de delimitar o objeto de pesquisa, a opção por não investigar trabalhos que articulam questões exclusivas da trilha musical aparece uma vez que o espaço de estudo sobre a música no cinema além de muito amplo, possui questões intrínsecas à linguagem musical que competem especialmente aos pesquisadores da área de música e aos músicos propriamente ditos.

61 Esta expressão é inspirada na dissertação de mestrado de FLORES (2006) que, como será citado ao final deste tópico, apresenta o termo "cenografias sonoras" relacionado aos sons que compõem o ambiente da 
Assim, a investigação aprofunda-se na descrição dos sons correspondentes de cada elemento, utilizando-se de uma "escuta figurativa" e buscando auxílio na materialidade e espacialização desses sons.

Já os três artigos são: "A Trilha Sonora do Cinema: proposta para um 'ouvir' analítico" (SILVA, 2007), "De Olhos e Ouvidos Bem Abertos: uma classificação dos sons no cinema" (SILVA, 2008) $)^{62}$ e "Pensando a trilha sonora para audiovisual" (LEME, 2011). Os dois primeiros analisam a trilha sonora no cinema segmentando-a em música, efeito sonoro e voz, e propõem três classificações do som inspiradas nas categorias do filósofo americano Charles Sanders Peirce. São elas: não-representativo, figurativo e representativo. O silêncio é lembrado brevemente como mais um recurso inserido à trilha sonora. E o terceiro, muito semelhante, além de partir da mesma divisão (voz, efeito sonoro e música), cita as classificações propostas por SILVA (2007 e 2008), e ainda fragmenta o som em relação à sua natureza musical e suas propriedades qualitativas como timbre, duração, altura e intensidade.

Além disso, para acrescentar, pode-se constatar que a reflexão sobre a trilha sonora relacionada à disposição teórica de seus elementos, também é encontrada em partes de outros trabalhos com a intenção de entender o significado e o papel de cada componente dentro da narrativa fílmica. Por exemplo: em parte da dissertação "O Lugar Fora do Lugar: topografias sonoras do cinema documentário" (PESSOA, 2011) as funções da voz, da música, dos ruídos e do silêncio é avaliada de acordo com as perspectivas de Michel Chion e do pesquisador e compositor sueco Johnny Wingstedt. Em um capítulo da dissertação "Movimentos Invisíveis: a estética sonora do cinema de animação" (WERNECK, 2010), o papel da voz, da música e dos ruídos são estudados especificamente dentro do cinema de animação, concentrando nos textos de Alberto Cavalcanti, David Bordwell e Kristin Thompson e Michel Chion. E mesmo no trabalho de mestrado "O Cinema, uma arte sonora” (FLORES, 2006), há também reflexões acerca dos elementos da trilha sonora, mesclando divisões teóricas e práticas, seja utilizando a classificação tradicional em voz, ruídos e música, ou baseando-se, por exemplo, na metodologia adotada pela editora de som francesa Emmanuelle Castro, que trabalhou no Brasil no final da década de 1970, subdividindo os elementos em diálogos, música e ruídos (ruídos de sala, efeitos especiais sonoros, e ruídos de pista ou de arquivo), incluindo o que prefere denominar de "cenografias sonoras", ou seja, os sons que compõem o ambiente da cena.

cena.

62 Esses dois artigos de Márcia Carvalho da Silva são praticamente idênticos. A única diferença é que no primeiro há um ítem a mais onde é realizada uma análise aplicada ao filme Baile Perfumando (Paulo Caldas e Lírio Ferreira, 1997). 
Agora de maneira individual, os estudos da voz, dos ruídos e do silêncio são apresentados como mais temáticas evidentes na pesquisa brasileira contemporânea sobre o som no cinema.

\subsubsection{Estudos da Voz}

Desempenhando papel fundamental na estrutura narrativa cinematográfica, a voz (a palavra, a fala, os diálogos) é um elemento de destaque na trilha sonora. A intenção aqui é de alocar os trabalhos que tratam especificamente da voz no cinema como sonoridade, como componente sonoro relacionado à imagem. E não através de seu lado semântico, conforme alguns pesquisadores a estudam, relacionando-a à questão textual ou por intermédio de sua função de enunciação e construção de sentido, como por exemplo, já aprofundaram teóricos como Jean-Claude Bernardet ${ }^{63}$ e Ismail Xavier ${ }^{64}$.

A ambivalência dos estudos sobre a voz no cinema é considerada na tese "Por uma Política da Voz no Cinema: estratégias para emancipação do espectador em 'Memórias do Subdesenvolvimento' de Tomás Gutiérrez"65 (DÖPPENSCHMITT, 2010). Embora busque mostrar a relevância da voz e seu alcance político no longa-metragem Memórias do Subdesenvolvimento (Tomás Gutiérrez Alea, 1968) por meio da aproximação com o texto fílmico, a pesquisa também analisa a voz em sua materialidade e mediatizada pelo cinema. Desta forma, a tese de Elen Döppenschmitt também contribui para essa temática uma vez que apresenta algumas teorias específicas sobre a voz do cinema, como conceitos e denominações estabelecidas diante a relação da voz e o espaço no cinema, presentes por exemplo, na obra La Voix au Cinema de Michel Chion. Além disso, a pesquisa insere questões da oralidade e da performance na investigação do filme, chegando a refletir também sobre a relação da voz com o ritmo e a montagem em algumas sequências da obra. Parte dessa tese foi anteriormente publicada em dois artigos intitulados: "A voz nas Memórias do Subdesenvolvimento: de Edmundo Desnoes a Tomás Gutiérrez Alea" (DÖPPENSCHMITT, 2007a) e "Por uma Política da Voz: Tomás Gutiérrez Alea e as Memórias do Subdesenvolvimento" (DÖPPENSCHMITT,

63 BERNARDET, Jean-Claude, AVELlar, José Carlos, MONTEIRO, Ronald F. Anos 70: Cinema. Rio de Janeiro, Europa Editora, 1979-1980. , Jean-Claude. Cineastas e imagens do povo. São Paulo: Cia das Letras, 2003.

64 XAVIER, Ismail N.. Corrosão social, pragmatismo e ressentimento: vozes dissonantes no Cinema Brasileiro de Resultados. Novos Estudos. CEBRAP, v. 75, p. 139-155, 2006. , Ismail N.. O Olhar e a Voz: a narração multifocal do cinema e a cifra da história em São Bernardo. Literatura e Sociedade, São Paulo, v. 2, p. 127-138, 1997.

65 Em 2013 essa tese foi adaptada, editada e publicada em formato de livro pela editora EDUC, em parceria com a Fapesp, intitulado "Políticas da Voz no Cinema em Memórias do Subdesenvolvimento". 
2008).

A importância da voz no cinema documentário também é salientada pela dissertação de Döppenschmitt, denominada "Um Estudo da Performance da Oralidade no Cinema: registros da voz na linguagem documental" (2005). Mais uma vez transitando pelas diferentes possibilidades de estudo da voz no cinema, a pesquisa analisa o filme Adão ou Somos Todos Filhos da Terra (Walter Salles e Daniella Thomas, 1998) apropriando-se principalmente dos conceitos do teórico suíço Paul Zumthor para investigar as questões das performances da voz, e contribuir para o estudo da oralidade nas mídias. A maneira como foram elaboradas certas sonoridades, espacialidades, performances e construções poéticas da voz na obra é observada, entendendo a tradição oral como uma tradição de escuta. Portanto, decidiu-se da mesma forma considerar esse trabalho de mestrado nesta temática, já que também complementa o percurso evolutivo do pensamento da pesquisadora. Atrelado à dissertação está ainda o artigo "Voz e Canto Popular do Negro no Cinema - poética cinematográfica no documentário Adão ou Somos Todos Filhos da Terra de Walter Salles e Daniela Thomas" (DÖPPENSCHMITT, 2007b) que faz um apanhado geral da pesquisa.

Os conceitos teóricos de Michel Chion e Paul Zumthor relacionados à voz também são muito bem trabalhados no artigo "Vozes Polifônicas e Escutas Musicais: a articulação da banda sonora em François Girard" (MIRANDA, 2007). O texto analisa a exploração sonora da voz no filme de François Girard sobre o pianista Glenn Gould (Thirty-two short films about Glenn Gould, 1993), articulando-a com questões da escuta fílmica, destacando a performance vocal e a voz acusmática.

A procura de outras formas de utilização da voz no cinema é a cerne do artigo "São Bernardo: mosaico de vozes (mostruário dos diversos usos da voz no cinema)" (COSTA, 2003c). Usos não convencionais da voz são demonstrados a partir do filme São Bernardo (Leon Hirszman, 1973). Discute-se a relação dos diálogos com os planos e enquadramentos utilizados, questões de sincronismo, de deslocamento espaço-temporal da voz, e relações entre vozes e imagens no filme. Já a narração em off recebe atenção especial no artigo "O ensaio no documentário e a questão da narração em off' (LINS, 2007). Partindo da investigação das experiências do cineasta francês Chris Marker e da belga Agnès Varda, que utilizam a narração em off de modo ensaístico, as possibilidades estéticas do uso da voz off e sua relação com o cinema documentário brasileiro também são refletidas.

Através das manifestações vocais dos atores e personagens, a voz no cinema é também interesse de estudo presente no campo da fonoaudiologia. Na dissertação "Análise dos Padrões de Voz no Cinema: a comunicação oral humana em duas versões de The Nutty 
Professor" (CASTRO, 2001), o uso da voz e de alguns aspectos da comunicação oral são comparados nos filmes O Professor Aloprado (Jerry Lewis, 1963) e seu remake de 1993, dirigido por Tom Shadyac. Para isso, são realizadas medições da duração e da incidência de manifestações da comunicação oral humana no filme, além de avaliações das vozes dos principais personagens, relacionando-as às psicodinâmicas vocais habituais e às variações de vozes de acordo com o contexto narrativo.

A questão da expressividade oral no cinema também é investigada na dissertação "Expressividade Oral no Cinema: diálogos com a fonoaudiologia" (SOUZA, 2010), havendo tanto uma exposição teórica do que já foi estudado sobre o cinema no campo da fonoaudiologia, quanto uma análise sobre o papel do preparador de elenco nos filmes e seus procedimentos de trabalho. Partindo de relatos de seis diretores, seis atores e uma editora de som entrevistados ${ }^{66}$, uma proposta didática é organizada para um melhor entendimento do processo de construção da expressividade vocal do ator no cinema, que envolve a prática de realização fílmica - da pré-produção até a finalização - e a reflexão sobre a atuação fonoaudiológica no cinema brasileiro contemporâneo. Alguns parâmetros vocais encontrados que influenciam nesse processo foram: qualidade vocal e pitch, projeção e loudness, articulação, ressonância, prosódia, sotaque e regionalismo. O trabalho com a edição de som e dublagem também são compreendidos como ferramentas reparadoras.

Já a dissertação "A Voz na Mise en Scène: o filme Cidade de Deus sob a escuta fonoaudiológica" (AMARAL, 2006) analisa a relação entre a voz e os demais elementos da linguagem cinematográfica. Ou seja, partindo da investigação sobre a produção do filme Cidade de Deus (Fernando Meirelles e Kátia Lund, 2002), é pesquisada a ligação entre as qualidades de entoação, velocidade, loudness, prolongamento e pausa da voz dos atores, juntamente com questões da interpretação, do cenário, da iluminação, do figurino, das cores, da velocidade e movimentos de câmera, da montagem, da trilha musical e de demais sons, verificando os efeitos dessa relação na mise en scène da obra.

O estudo da voz compreendido no campo da fonoaudiologia é ainda presente em mais dois artigos, ambos com co-autoria de SOUZA e AMARAL. O primeiro é o intitulado "A Fonoaudiologia e o Ator de Cinema: relatos de profissionais do meio cinematográfíco" (AMARAL; FERREIRA; SOUZA, 2010a) que através de relatos de três atores, quatro fonoaudiólogas e um diretor entrevistados ${ }^{67}$, investiga o trabalho desenvolvido com a voz e a fala pelos profissionais do meio cinematográfico, enfatizando a atuação fonoaudiológica e

66 A identidade dos entrevistados não é revelada no texto.

67 A identidade dos entrevistados também não é revelada no texto. 
abordando a construção da personagem, a interpretação, a relação com o diretor, a fragmentação da interpretação, a expressão vocal, técnicas vocais específicas, o trabalho e a demanda fonoaudiológica. E o segundo, "Representações de Voz e Fala no Cinema" (AMARAL; FERREIRA; MARTZ; SOUZA, 2010b), proveniente da dissertação de AMARAL (2006), investiga o papel interpretativo dos recursos de voz e da fala em três sequências do filme Cidade de Deus ${ }^{68}$, articulando aspectos da voz relacionados à mise en scène e o contexto de produção do filme.

Através da tese, das quatro dissertações e dos oito artigos aqui alocados, observa-se que o estudo da voz no cinema é uma temática hibrida mesmo enquanto sonoridade. Resumindo, basicamente tem-se debates sobre a relação entre a voz e o espaço cinematográfico, a questão da oralidade, a performance da voz, algumas possibilidades estéticas de utilização da voz, e o quanto a interdisciplinaridade entre fonoaudiologia e cinema pode contribuir para a expansão dessas duas áreas de conhecimento, favorecendo assim, o aprofundamento sobre as manifestações vocais na "sétima arte". Nota-se uma forte integração entre as pesquisas do campo da fonoaudiologia. Além das publicações em conjunto de SOUZA e AMARAL, ambas citam a dissertação de CASTRO (2001) como referência importante de pesquisa. O estudo da voz especificamente no cinema documentário também é contemplado.

\subsubsection{Estudos do Ruído}

A palavra ruído possui uma variedade de significados. A intenção aqui é abordar os trabalhos que tratam do ruído como elemento sonoro no cinema, e não como sinônimo de interferência. Logo, o conceito de ruído empregado é referente aos sons que compõem a trilha sonora e que não são claramente musicais nem linguísticos. E ainda, acrescentando a título de esclarecimento, com a dinâmica de trabalho da pós-produção de som nos filmes pode-se dividir os ruídos basicamente em três categorias:

- ruídos de ambiente ou background: relativo aos sons da "paisagem sonora" da diegese, geralmente concebidos a partir da complexidade geográfica da cena. Por exemplo: sons que compõem o ambiente de uma floresta, ou de uma cidade, etc;

- ruídos de efeito ou efeito sonoro: do inglês sound effects, são sons provenientes de algum objeto ou fonte sonora específica. Por exemplo: o som de carros, aviões, tiros, explosões;

68 Aqui vale a correção de um pequeno equívoco: no artigo consta que o filme é do ano de 2005, mas consultando o Internet Movie Database, principal base de dados de filmes na internet, o filme é datado no ano de 2002. 
- ruído de sala (mais conhecido como foley ${ }^{69}$ ): termo utilizado para denominar o processo de recriação de ruídos e criação de sons especiais em estúdio, sincrônicos com a imagem, principalmente aqueles sons relacionados a movimentos e ações dos atores, como por exemplo: passos, socos, tapas, farfalhar de roupa, contato com objetos de cena, etc.

De fato são poucos os estudos específicos sobre o ruído como elemento sonoro no cinema. Apenas três artigos dedicam-se exclusivamente a refletir sobre este componente da trilha sonora. Cabe já destacar que as pesquisas pertencentes a esta temática exploram de maneira fundamental a teoria do canadense Murray Schafer e seu conceito de "paisagem sonora", associando-as ao contexto cinematográfico.

A possibilidade do cinema representar o ambiente sonoro no qual vive o homem contemporâneo urbano, onde os ruídos tornam-se matéria-prima essencial para a produção cinematográfica, é a discussão proposta pelo artigo "Pode o cinema contemporâneo representar o ambiente sonoro em que vivemos?" (COSTA, 2010b). Assim, principalmente a partir dos conceitos de Schafer, é articulada a relação entre o cinema como meio de expressão audiovisual e as paisagens sonoras cada vez mais repletas de ruídos.

Já a relação entre o processo de composição dos sons ambientes e o conceito de paisagem sonora de Schafer é aplicada ao filme Ensaio Sobre a Cegueira (Fernando Meirelles, 2008) no artigo “A Paisagem Sonora e a Ambientação do Desenho de Som: os sons ambiente como localizadores espaciais e temporais no filme Ensaio Sobre a Cegueira" (OPOLSKI, 2009b). Como o título do trabalho explicita, são analisados os sons que caracterizam os ambientes desempenhando a função de localização espacial e geográfica na narrativa da obra.

A utilização do ruído fora-de-campo como força expressiva cênica nos filmes Hamaca Paraguaya (Paz Encina, 2006), O Pântano (Lucrécia Martel, 2001) e A Mulher Sem Cabeça (Lucrécia Martel, 2008) é discutida no artigo “A Submersão nas Imagens Sonoras: o som e suas dimensões reais e imaginárias" (CUNHA, 2011). Sem deixar de citar a paisagem sonora de Murray Schafer, o texto expande-se diante a análise dos estímulos audiovisuais e as dimensões sensoriais provocadas no espectador pela relação entre imagens e ruídos nos filmes investigados.

Além dessas três pesquisas, complementando os estudos do ruído no cinema, o artigo "Paisagens sonoras de Robert Bresson" (ALVIM, 2011) colabora com essa temática ao relacionar o conceito de Schafer com a obra de Bresson, identificando as funções narrativas e a musicalidade dos principais ruídos que compõem as paisagens sonoras dos filmes do

${ }^{69}$ O termo "foley" é referente a Jack Foley (1891-1967), um dos pioneiros na arte de recriação de ruídos. 
cineasta francês. Outro que também trás contribuições é o artigo "Efeitos Sonoros Enquanto Fala Audiovisual: análise de Gerald McBoing-Boing à luz do §528 das Investigações Filosóficas" (VENANCIO, 2011), que analisa o uso dos efeitos sonoros nos curtas de animação da UPA (United Productions of America) estrelados pela personagem Gerald McBoing-Boing, a qual se comunica por meio de ruídos. E mais, já fazendo uma ligação com a próxima temática referente ao estudo do silêncio, o artigo "Ruídos e Silêncio: proposta para uma estética do som no cinema" (COSTA, 2003d) evidencia a importância dos ruídos e do silêncio no som cinematográfico. Indagando a predominância da voz, o trabalho demonstra a relevância do ruído e do silêncio nas artes no século XX, citando momentos na teoria e nos filmes onde há a valorização desses dois elementos. Este texto é na verdade uma prévia de algumas ideias mais aprofundadas na dissertação do mesmo autor, denominada "Som no Cinema, Silêncio nos Filmes: o inexplorado e o inaudito" (COSTA, 2003a), em especial sobre o conteúdo de seu terceiro capítulo intitulado "Silêncio, Ruído".

Apesar de pequeno o número de materiais que se dedicam a estudar o ruído no cinema, nota-se a preocupação em destacar este elemento que, ao mesmo tempo que pode simplesmente redundar as ações imagéticas, pode ter seu potencial utilizado como elemento criativo e participar ativamente da construção dramática e emocional de uma determinada narrativa.

\subsubsection{Estudos do Silêncio}

O estudo do silêncio como elemento constitutivo do som cinematográfico é também uma tendência temática evidenciada na pesquisa brasileira contemporânea, sendo contemplado diretamente apenas por dois artigos. Desta maneira, assim como os estudos do ruído, esta pode ser considerada uma temática pouco explorada.

Os artigos são: "Se pouco se diz sobre o som, quem fala sobre o silêncio nos filmes?" (COSTA, 2004b) e "Os caminhos dos usos dos silêncios (ou a lembrança que não passa de John Cage)" (COSTA, 2011). Ambos os textos são de Fernando Morais da Costa e também possuem forte ligação com parte de sua dissertação a pouco citada, "Som no Cinema, Silêncio nos Filmes: o inexplorado e o inaudito" (2003a). Nota-se que o estudo do silêncio e dos ruídos no cinema é recorrente nos trabalhos de COSTA, o qual entende que ambos os elementos possuem uma relação intrínseca entre si. Para pensar o silêncio e sua aceitação como parte integrante de um fenômeno sonoro, o pesquisador realiza um resgate de como este elemento já fora refletido na literatura, na música, na mitologia, na filosofia, na história, na cultura dos 
povos, etc. Em relação ao cinema, as análises tomam como ponto de partida a materialidade dos silêncios nos filmes, ou seja, silêncio da voz, dos ruídos, da música ou mesmo instantes de silêncio total na tela. Há também a reflexão sobre como se constrói uma intervenção silenciosa em meio aos sons de filmes, como se dá sua percepção, e o que isso pode significar. Portanto, é desta forma que a questão do silêncio é desenvolvida nos artigos mencionados.

Dois outros artigos podem colaborar com esta temática, uma vez que demonstram o uso do silêncio como parte integrante da narrativa fílmica. O primeiro, intitulado "Robert Bresson: o cinema num atormentado silêncio" (DOBAL, 2003), evidencia a utilização do silêncio na obra de Bresson, constando que o diretor francês recorria a este elemento "como uma forma de fazer com que os gestos e os objetos se tornassem falantes e os sons voltassem a ser realmente sonoros". E o segundo, denominado "O rádio e os silêncios: articulações sobre o uso do som em Cinema, Aspirinas e Urubus" (CARREIRO, 2010a) que, em parte, verifica a interferência provocada pelos silêncios nos significados que os espectadores conseguem extrair da decupagem visual do filme Cinema, Aspirinas e Urubus (Marcelo Gomes, 2005).

De fato o silêncio ainda é pouco debatido na pesquisa brasileira sobre o som cinematográfico. Mas, por mais complexo e subjetivo que seja o conceito de silêncio, seja relacionado com o discurso, com a música ou com o ruído, esta categoria reflete a participação deste elemento também no universo da trilha sonora cinematográfica, dando um passo importante para a ampliação do campo de estudos e percepções do som no cinema.

\subsubsection{Teoria}

Observando alguns trabalhos que discorrem diretamente sobre a teoria do som no cinema, tipos de análise fílmica ou o campo dos estudos do som propriamente dito, é concebida a classificação intitulada Teoria. Para esclarecer, visto que é uma atividade intrínseca à pesquisa acadêmica a utilização de um arcabouço teórico como base de referência ou preparação para alguma discussão, essa categoria agrupa somente materiais que refletem sobre a própria teoria em si. Este tipo de abordagem é encontrado especificamente em apenas dois artigos. São eles:

O artigo "O Soundscape da Modernidade: os Sound Studies e o som no cinema" (CASTANHEIRA, 2011a), que discute a contribuição do campo dos Sound Studies à análise do som no cinema, principalmente através dos trabalhos de Jonathan Sterne, Emily Thompson e Rick Altman. Também procura levantar algumas correntes dos estudos do som que, diante sua abordagem interdisciplinar, podem apresentar novas perspectivas para os estudos 
cinematográficos. E o artigo "Pensando a Relação Imagem-Som" (MENDES, 2004), que apresenta métodos de análise que permitem ampliar a discussão de uma obra cinematográfica através da integração entre os elementos visuais e sonoros. Depois de um apanhado das primeiras manifestações escritas acerca do som no cinema, a exemplo dos textos de realizadores como Eisenstein, Pudovkin, René Clair, Alberto Cavalcanti e teóricos como Béla Balázs, o trabalho expõe dois modelos teóricos de análise audiovisual: o da dupla David Bordwell e Kristin Thompson presente no artigo "Estética Fundamental do Som no Cinema"70, e o de Gerard Betton em "A Palavra e o Som"71. Ao final, MENDES não deixa de mencionar algumas propostas de Michel Chion reunidas no livro L'Audio-Vision ${ }^{72}$.

Um terceiro trabalho que muito ajuda a complementar essa seção é novamente a dissertação "Som no Cinema, Silêncio nos Filmes: o inexplorado e o inaudito" (COSTA, 2003a) e, especialmente, seu segundo capítulo designado "A teoria, a análise e o espaço do som". Refletindo sobre a conquista dos estudos do som no cinema como novo campo de pesquisa no meio acadêmico, resgata os documentos que hoje podem ser considerados componentes de uma teoria clássica do som cinematográfico, e chega na contemporaneidade distinguindo o discurso de dois principais pensadores contemporâneos da área: o norteamericano Rick Altman e o francês Michel Chion.

Apesar de pequena, a discussão focada na teoria do som no cinema torna-se responsável por contextualizar o desenvolvimento dos estudos na área. Mais que um aglomerado de conceitos, teorias e teóricos, amplia as possibilidades de se pensar o som como objeto de pesquisa no cinema. Assim, mostrar como o som é problematizado na teoria cinematográfica também colabora para o melhor entendimento do cinema como arte audiovisual.

\subsubsection{Estética e Estilo}

Estética e estilo são dois conceitos diferentes mas que podem estar associados. A diferenças entre eles pode ser compreendida a partir da citação a seguir, relacionada à discussão textual dos termos:

Estética é a percepção visual de um texto, com seus elementos, considerando o processamento das informações que atingem o cérebro. A estética está, então, na ordem lógica em que o texto se desenvolve, na riqueza de argumentações e fundamentações na correção do uso da língua vernácula e na objetividade do texto. $\mathrm{O}$ estilo é a combinação de elementos visuais, dentro de uma frequência de distribuição,

\footnotetext{
70 In Elisabeth Weis e John Belton (org.), Film Sound: theory and practice (Nova Iorque: Columbia University Press, 1985), p. 181-199.

71 Gerard Betton, Estética do Cinema (São Paulo: Martins Fontes, 1987), p. 37-51.

72 Michel Chion, L'Audio-Vision (Paris: Nathan, 1991).
} 
que expressam características distinguíveis que denotam o escritor ou pesquisador, a época, a cultura ou a localização em que aquele texto foi concebido e produzido. [...] Então, a estética é a visualização e processamento de informação e o estilo ocorre quando, visualizando um texto (observando a estética), consegue-se identificar características que denotem sua origem. (MASSAD, 2006: 6)

Sendo assim, estilo pode ser considerado um atributo estético. Por conta desta associação, optou-se em unir estes conceitos em uma só tendência temática, reunindo trabalhos que discutem prioritariamente questões estéticas e estilísticas do som no cinema.

A questão estilística é levantada nos textos "Sobre o Som no Cinema de Horror: padrões recorrentes de estilo" (CARREIRO, 2011b) e "Som e ritmo interno no plano-sequência" (COSTA, 2010a). O primeiro busca listar alguns recursos estilísticos recorrentes no som do cinema de horror. Definindo o cinema de horror como gênero cinematográfico, é então analisada a recorrência de certas técnicas ou padrões narrativos no uso de três elementos da trilha sonora (voz, música e ruídos) diante alguns filmes que encaixam nesse gênero. $\mathrm{E}$ o segundo discute um caso estilístico mais específico ainda, o da movimentação do som dentro do procedimento do plano-sequência no cinema, ou seja, a criação de ritmos distintos entre som e imagem dentro de um mesmo plano.

A representação hiper-realista do som no cinema argentino atual e as experimentações sonoras do cinema brasileiro contemporâneo são analisadas respectivamente pelos artigos "Pode-se dizer que há algo como um hiper-realismo sonoro no cinema argentino?" (COSTA, 2011a) e "Como soa hoje experimental?" (COSTA, 2011b). A busca por responder as duas perguntas que intitulam os textos, faz parte da pesquisa de COSTA cuja proposta é analisar usos do som no cinema contemporâneo, reconhecendo características sonoras presentes nesse cinema. Outro artigo, também de COSTA, denominado "Ruídos e Silêncio: proposta para uma estética do som no cinema" (2003d), faz uma análise estética do som no cinema onde ao mesmo tempo que contextualiza e constata a existência de um domínio da voz na maior parte da produção cinematográfica mundial, explica o aumento da importância de ruídos e de silêncios na teoria e prática das artes no século XX, primeiro especificando o caso da música e depois o do cinema.

A estética do som no cinema documentário é abordada pela dissertação "O Lugar Fora do Lugar: topografias sonoras do cinema documentário" (PESSOA, 2011). O objetivo é refletir sobre as relações entre escolhas estéticas, relacionadas principalmente ao uso do som, e as consequências políticas dessas escolhas. Além de apresentar as diversas funções dos elementos da trilha sonora e discutir os modos de estruturação do cinema documental elaborados pelo teórico norte-americano Bill Nichols, a pesquisa analisa os filmes Entuziazm 
ou Simfonija Donbassa (Dziga Vertov, 1931), Titicut Follies (Frederick Wiseman, 1967), Chulas Fronteras (Les Blank, 1974) e The Invisible Frame (Cynthia Beatt, 2009).

Como complementação, além da dissertação e dos cinco artigos aqui mencionados, outros trabalhos dialogam com esta temática. Por exemplo: as possibilidades estéticas do uso da narração em off no cinema documentário é motivo de análise no artigo "O ensaio no documentário e a questão da narração em off' (LINS, 2007). Outros dois trabalhos discutem usos estéticos do som com foco no cinema de animação: a dissertação "Movimentos Invisíveis: história da estética do som do cinema de animação" (WERNECK, 2010) e o artigo "Efeitos Sonoros Enquanto Fala Audiovisual: análise de Gerald McBoing-Boing à luz do $\S 528$ das Investigações Filosóficas" (VENANCIO, 2011). No trabalho de mestrado pode ser encontrado um levantamento histórico e teórico de diversas possibilidades da linguagem sonora cinematográfica desenvolvidas no cinema de animação. E no artigo, discussões acerca da crítica estética do estúdio de animação norte-americano UPA, e as possibilidades linguísticas do uso do efeito sonoro no caso do desenho animado de Gerald McBoing-Boing. E mais, o artigo "Os Sons da Continuidade Intensificada: o caso de Sergio Leone" (CARREIRO, 2011a), por exemplo, tem a intenção de averiguar algumas ferramentas que proporcionam a experiência intensificada de fruição na trilha sonora, analisando a obra de Sergio Leone e tomando de base o conceito de "continuidade intensificada" de David Bordwell, que segundo o artigo, abrange um repertório cada vez mais amplo de recursos narrativos e estilísticos no cinema.

\subsubsection{Estudos de Caso}

No processo de identificação de semelhanças para estabelecer vínculos temáticos na pesquisa brasileira contemporânea sobre o som cinematográfico, nota-se um número significante de trabalhos que focam estudar aspectos do som aprofundando em casos específicos, ou seja, aplicando alguma perspectiva de estudo sobre um caso individual, como por exemplo, um cineasta ou um filme escolhido. Logo, os trabalhos que estão aqui classificados são aqueles que centralizam suas análises em casos exclusivos. O leitor pode então perceber que alguns materiais já alocados em outras seções poderiam estar aqui agregados. Por exemplo, aqueles que investigam alguma questão do som em um filme particular, como as dissertações de OPOLSKI (2009a), de PEREIRA (2010), de AMARAL (2006), de DÖPPENSCHMITT (2005), as teses de DÖPPENSCHMITT (2010), de SOUZA (2011), etc. Desta forma, vale lembrar que com a amplitude de assuntos, temas, subtemas e 
objetos de estudo encontrados nos materiais, realmente há trabalhos que podem pertencer a mais de uma categoria. Reafirmando: todas as divisões propostas não são consideradas exclusivas. Assim, a temática Estudos de Caso é a mais abrangente, contendo um livro, quatro dissertações e dezoito artigos. Fora os trabalhos que poderiam estar aqui agrupados mas que já foram organizados em outras seções, a exemplo das dissertações e teses dos autores há pouco citados.

A obra do cineasta francês Robert Bresson é foco de algumas pesquisas. O trabalho de mestrado intitulado "Entre a escuta e a visão: o lugar do espectador na obra de Robert Bresson" (ASPAHAN, 2008) investiga a maneira como os filmes de Bresson reivindicam do espectador modos de olhar e de escutar. Para isso são realizadas duas analises: uma a respeito da composição sonora e sua relação com a escuta no filme Um condenado à morte escapou ou $O$ vento sopra onde quer (1956), e outra concentrada na composição visual de Uma criatura dócil (1969). Já o artigo "Paisagens sonoras de Robert Bresson” (ALVIM, 2011) analisa, como o título já demonstra, a paisagem sonora das obras do diretor francês, especialmente no filme $O$ dinheiro (1983), discutindo o conceito cunhado por Murray Schafer e identificando as funções narrativas e o uso musical do ruído em seus filmes. E o artigo "Robert Bresson: o cinema num atormentado silêncio" (DOBAL, 2003), que discorre sobre como o diretor utilizava o recurso do silêncio em seus trabalhos, explorando diversas nuances de sua forma diferenciada de fazer e pensar o cinema.

O cinema da diretora argentina Lucrecia Martel também tem sido motivo de analise. Sua obra, sua trajetória, suas opções estéticas e as singularidades da forma como o som é pensado na criação de seus filmes são elucidadas na dissertação "A experiência do cinema de Lucrecia Martel: resíduos do tempo e sons à beira da piscina" (BARRENHA, 2011). Deste modo, o som é o elemento chave que conduz o estudo sobre os três longas-metragens da cineasta: $O$ Pântano (2001), A Menina Santa (2004) e A Mulher Sem Cabeça (2008). Um panorama do cinema argentino desde seus primórdios até a contemporaneidade, destacando o emergência do Nuevo Cine Argentino, também é contextualizado. Observa-se que parte dessa dissertação foi anteriormente publicada no artigo intitulado "À beira da piscina, à beira do quadro: a utilização do som off e a construção de tensão na obra de Lucrecia Martel" (BARRENHA; PASSOS, 2009). Outro trabalho que também discorre sobre Martel é o artigo "Lucrecia Martel e o benefício da incerteza" (MENDES; PINTO, 2005). Desta vez refletindo sobre as relações audiovisuais narrativas e a intervenção sonora proporcionando novas leituras da imagem no filme A Menina Santa (2004).

Stanley Kubrick é mais um diretor contemplado. O pensamento audiovisual de Kubrick 
é estudado no artigo "A relação imagem/som nos filmes de Kubrick" (MENDES; CARRASCO, 2007). Dedicando-se principalmente à obra 2001: Uma odisséia no espaço (1968), o texto ressalta a consciência do diretor para com o potencial do som na narrativa fílmica. E o filme De olhos bem fechados (1999) é analisado sob o aspecto da interseção das linguagens sonora e imagética na dissertação "O Compositor Stanley Kubrick: análise do som do filme De olhos bem fechados de Stanley Kubrick através da teoria sonora de Michel Chion" (MARCOLINO, 2008) que, como pode ser percebido pelo título, utiliza-se a teoria de Michel Chion como aparato de investigação da obra. Esse trabalho de mestrado também destaca a figura de Kubrick por utilizar o potencial do material sonoro na obra.

Outros cineastas estudados são: Fritz Lang, Sergio Leone e Walter Murch. A experiência do diretor Fritz Lang é estudada no livro "Som-Imagem no Cinema: a experiência alemã de Fritz Lang” (MANZANO, 2003). Realizando uma reflexão teórica acerca do papel do som tanto no cinema mudo quanto no cinema sonoro, o trabalho dedica à contextualização histórica e ao processo de evolução do cinema expressionista alemão, fazendo a aplicação prática dos conceitos de som estudados em dois longas-metragens de Fritz Lang: Metropolis (1925-1926) e M, o Vampiro de Düsseldorf (1931). Já Sergio Leone e sua obra são analisados no artigo "Os Sons da Continuidade Intensificada: o caso de Sergio Leone" (CARREIRO, 2011a) com o intuito de averiguação de algumas ferramentas que proporcionam a experiência intensificada de fruição na trilha sonora. O conceito de continuidade intensificada de David Bordwell é que da a base teórica da discussão. E o trabalho do diretor, montador e sound designer Walter Murch é pesquisado no artigo "Walter Murch: a revolução da trilha sonora cinematográfica" (MENDES, 2006). A importância de Murch na mudança do pensamento sonoro dos filmes norte-americanos de ficção é demonstrada através da análise das trilhas sonoras realizadas por ele na década de 1970, em especial em dois filmes de Francis Ford Coppola: O Poderoso Chefão (1972) e Apocalypse Now (1979). Este artigo é um apanhado geral da tese de MENDES (2000).

O filme O Silêncio (1998) do diretor iraniano Mohsen Makhmalbaf é interesse de pesquisa de dois trabalhos. O artigo "A Narrativa Fonocinematográfica em O Silêncio: audição subjetiva e cronotopias do espaço fílmico" (CALEIRO, 2011) estuda as abordagens sonoras do filme, dando atenção ao uso do "ponto de escuta" (ou "ponto-de-audição") de Chion, e refletindo também sobre a relação audiovisual baseada tanto no conceito de "cronotopia" de Mikhail Bakhtin, quanto nos pressupostos teóricos da "gramatologia" de Jacques Derrida. O outro trabalho que estuda o caso do filme $O$ Silêncio é a dissertação "Som no Cinema, Silêncio nos Filmes: o inexplorado e o inaudito" (COSTA, 2003a). De fato esta 
dissertação consegue transitar por várias temáticas como já pode ser observado. Seja dialogando com a história, os estudos do ruído e do silêncio, ou refletindo sobre a teoria do som no cinema. Mas por encerrar o recorte da pesquisa analisando o caso desse filme citado, onde os apontamentos discutidos ao longo de todo o estudo são aplicados, decidiu-se portanto alocá-la aqui nesta temática.

O longa-metragem Cinema, Aspirinas e Urubus (Marcelo Gomes, 2005) também é analisado por dois trabalhos: os artigos "O Rádio e os Silêncios: articulações sobre o uso do som em Cinema, Aspirinas e Urubus" (CARREIRO, 2010a) e "Relações entre imagens e sons no filme Cinema, Aspirinas e Urubus" (CARREIRO, 2010b) que na verdade possuem conteúdos idênticos. A partir da conexão com componentes da encenação, as articulações entre a trilha sonora e as composições visuais na construção da narratividade do filme é investigada. O uso do silêncio e dos sons oriundos do rádio são destacados, e o conceito de "valor agregado" de Michel Chion é a principal base teórica utilizada.

Um mapeamento do som e das paisagens sonoras do documentário Dong (Jia Zhang-ke, 2006) é realizado no artigo "Além do que se vê - o som e as paisagens sonoras no documentário Dong, de Jia Zhang-ke” (PIPANO, 2011). A reflexão acerca do uso do som envolve também o contexto de reconfigurações espaciais, sociais, políticas e estéticas da obra. Já a relação imagem e som do média-metragem Candinho (1976) de Ozualdo Candeias é analisada no artigo "Candinho: a construção do espaço narrativo através da relação imagemsom" (PEREIRA, 2009a) que, utilizando perspectivas teóricas de Michel Chion e Murry Schafer, percebe o elemento sonoro como parte fundamental tanto na construção do espaço da diegese, quanto da própria narrativa do filme.

A importância da trilha sonora nos longas-metragens Orfeu (Carlos Diegues, 1999) e Blue (Derek Jarman, 1993) é investigada respectivamente pelos artigos “Orfeu: do mito a realidade brasileira. A importância da trilha sonora na estratégia narrativa de Cacá Diegues e sua relação com o contexto sociocultural de uma época" (QUINTANA, 2009) e "A Trilha Sonora de um Filme Imaginário: uma análise do filme Blue (1993) de Derek Jarman" (QUINTANA, 2010). Nos dois casos são destacados a participação do som na estratégia narrativa dos filmes, sendo que no primeiro, mostrando como o som pode revelar o contexto sociocultural de uma época. E no segundo, analisando a experiência atípica onde o som é o único elemento narrativo diante uma tela azul, exigindo a participação do espectador e sua subjetividade na projeção mental de imagens.

A personagem Gerald McBoing-Boing, presente em quatro curtas-metragens de animação produzidos pela UPA e que se comunica através de efeitos sonoros, é o foco de 
investigação do artigo "Efeitos Sonoros Enquanto Fala Audiovisual: análise de Gerald McBoing-Boing à luz do §528 das Investigações Filosóficas” (VENANCIO, 2011), que busca entender as possibilidades linguísticas desse uso do som através da filosofia de Ludwig Wittgenstein e seu livro "Investigações Filosóficas"

O curta-metragem O Artista (Luiz Carlos Ribeiro Borges, 1967) e a construção de seu espaço sonoro é o ponto central de estudo do artigo "O Artista Silencioso: um estudo da construção sonora no filme do Cineclube Universitário de Campinas" (ALMEIDA, 2011). Através de uma abordagem histórico-analítica, o texto estabelece relações entre o filme e o cinema silencioso da cidade de Campinas, discorrendo também sobre a maneira como ocorreu a chegada do som às salas de cinema da cidade.

Chega-se então aos últimos trabalhos aqui agrupados. O artigo "Sonoridades do cinema: Tarkovsky e a heterocronia da escuta" (RODRIGUES, 2011), além de focar o estudo em um filme específicos, Stalker (1979) do cineasta russo Andrei Tarkovsky, levanta um debate bem contemporâneo sobre as fronteiras da trilha sonora cinematográfica, especialmente sobre a simbiose entre trilha musical e design sonoro. $\mathrm{O}$ fato de também estar associado aos estudos da música no cinema, trouxe dúvida em relação à inserção ou não dessa pesquisa na revisão sistemática aqui proposta. Porém, considerou-se relevante inclui-la uma vez que este debate envolve outros aspectos importantes do som cinematográfico que não apenas questões exclusivas da trilha musical. Assim, o artigo de RODRIGUES começa fazendo um paralelo entre música e sonoplastia no cinema, compreendendo que ambas as áreas cooperam entre si em prol da força enunciativa, plástica e cênica de um filme. $O$ autor desfaz qualquer possibilidade de hierarquização entre música, sons e ruídos. Mediante a trilha sonora do filme Stalker, o trabalho utiliza-se do conceito de "endosmose" do filósofo francês Henri Bergson para afirmar que a arte cinematográfica é uma "heterocronia" de memórias, experiências e sensações.

Outro artigo onde pode ser observado mais um caso de intersecção entre os elementos da trilha sonora cinematográfica, quebrando barreiras do que é música e o que é ruído, e viceversa, é o denominado "A Sinfonia dos Pássaros" (TORRES, 2009). A construção dos sons do longa-metragem Os Pássaros (Alfred Hitchcock, 1963) é estudada a partir das escolhas sonoras presente no trabalho do diretor Hitchcock e do compositor Bernard Herrmann.

Estes últimos textos abrem margens para abordar outras pesquisas que ultrapassam as fronteiras da trilha sonora nesse sentido de convergirem aspectos da música e dos ruídos, da trilha musical e do sound design. Observa-se essa conexão presente em dissertações

73 WITTGENSTEIN, L. Investigações Filosóficas. São Paulo: Nova Cultura, 1999. 
orientadas pelo professor e pesquisador da UNICAMP, Ney Carrasco, como por exemplo, em "Futurismo e Música na trilha sonora de Dziga Vertov" (MAGALHÃES, 2005), em "Orfeu: do mito à realidade brasileira - uma análise da trilha sonora dos filmes Orfeu negro (1959) e Orfeu (1999) baseados na peça Orfeu da Conceição de Vinícius de Moraes” (QUINTANA, 2011), e em "A influência da trilha sonora sobre a percepção da obra cinematográfica: $A$ análise filmica de Bye bye Brasil, Pra frente Brasil e Central do Brasil" (VASCONCELOS, 2008). Ou mesmo em estudos do campo da "sonologia", como no artigo do professor e pesquisador de música eletroacústica da UFRJ, Rodolfo Caesar, intitulado "O tímpano é uma tela?" (CAESAR, 2004). Porém, essas pesquisas possuem um foco maior relacionado à música e suas questões específicas. Por isso, e para respeitar os limites propostos nessa revisão sistemática, elas não estão aqui contabilizadas nem analisadas.

Ao finalizar as tendências temáticas aqui propostas, observa-se que é recorrente na pesquisa brasileira contemporânea sobre o som no cinema, aplicar alguma perspectiva de estudo do som sobre um filme ou à obra de um cineasta específico ${ }^{74}$. Desta forma, a temática Estudos de Caso se torna a mais ampla, podendo inclusive abarcar trabalhos que realizam abordagens particulares sobre o som ainda não recorrentes entre os demais materiais, o que pelo contrário justificaria a formação de outras tendências temáticas. Já a temática História é a única que possui publicações nos quatro formatos de materiais coletados: livros, teses, dissertações e artigos. Uma informação extra que pode ser percebida é que, transitando entre essas tendências, estão um livro, três teses, seis dissertações e dezoito artigos que articulam questões relacionadas ao cinema nacional. Estes materiais podem ser conferidos listados no Anexo V deste projeto.

Mas de fato, a diversidade de abordagens dos estudos sobre o som no cinema aqui avaliados, certamente pode motivar outros olhares (ou ouvidos) diante essas classificações. Essas tendências aqui propostas representam hoje, uma das possibilidades de organização.

\subsection{Perfil}

A produção de novos conhecimentos em forma de texto e a formação de pesquisadores ligados diretamente ao ensino acadêmico, encontram nas teses, nas dissertações e nos artigos,

${ }_{74}$ A título de informação, existe uma lista bibliográfica (em inglês) sobre o som no cinema divida por filmes. Ela pode ser acessada neste link: $<$ http://www.filmsound.org/movielist/ $>$. 
materiais de grande prestígio na produção científica de uma área específica de conhecimento. Desta forma, julga-se importante destacar o perfil da pesquisa brasileira contemporânea sobre o som cinematográfico, focando tanto nos locais onde foram publicados, quanto nos pesquisadores autores.

Em relação à produção de trabalhos de doutorado e mestrado, nove universidades fomentaram a realização do total de cinco teses e vinte e uma dissertações. Dessas instituições, oito estão concentradas na região Sudeste do Brasil e apenas uma não se enquadra nesta atribuição, pertencendo a região Sul.

São elas: Universidade de São Paulo (USP); Pontifícia Universidade Católica de São Paulo (PUC-SP); Universidade Anhembi Morumbi (UAM); Universidade Estadual de Campinas (UNICAMP); Universidade Federal Fluminense (UFF); Universidade Federal do Rio de Janeiro (UFRJ); Universidade do Estado do Rio de Janeiro (UERJ); Universidade Federal de Minas Gerais (UFMG); e Universidade Federal do Paraná (UFPR). No gráfico a seguir notam-se os valores numéricos de teses e dissertações defendidas por cada uma dessas universidades.

\section{GRÁFICO II}

Quantidade total de teses e dissertações por universidade ${ }^{75}$ :

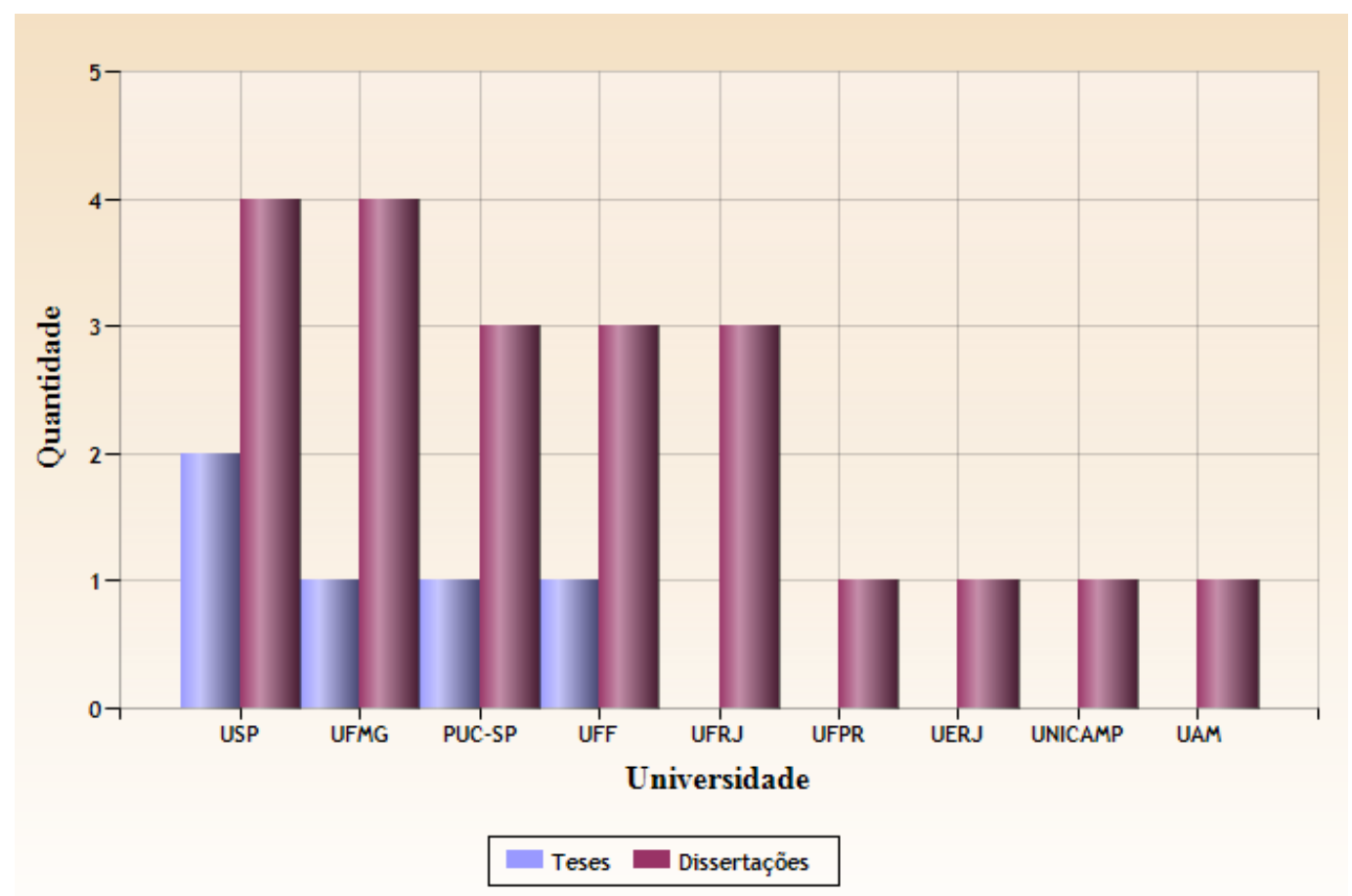

75 Confira a lista bibliográfica de teses e dissertações distribuídas por Universidade no Anexo III deste trabalho. 
A USP é a universidade que possui a maior quantidade de trabalhos fomentados, somando duas teses e quatro dissertações. Em seguida está a UFMG, que apresenta uma tese e quatro dissertações. Tanto a PUC-SP quanto a UFF possuem uma tese e três dissertações cada. Depois, está a UFRJ com três dissertações. E a UFPR, a UERJ, a UNICAMP e a UAM, todas com apenas uma dissertação. A seguir, a representação desses valores porcentualmente.

\section{GRÁFICO III}

Porcentagem de teses e dissertações por universidade:

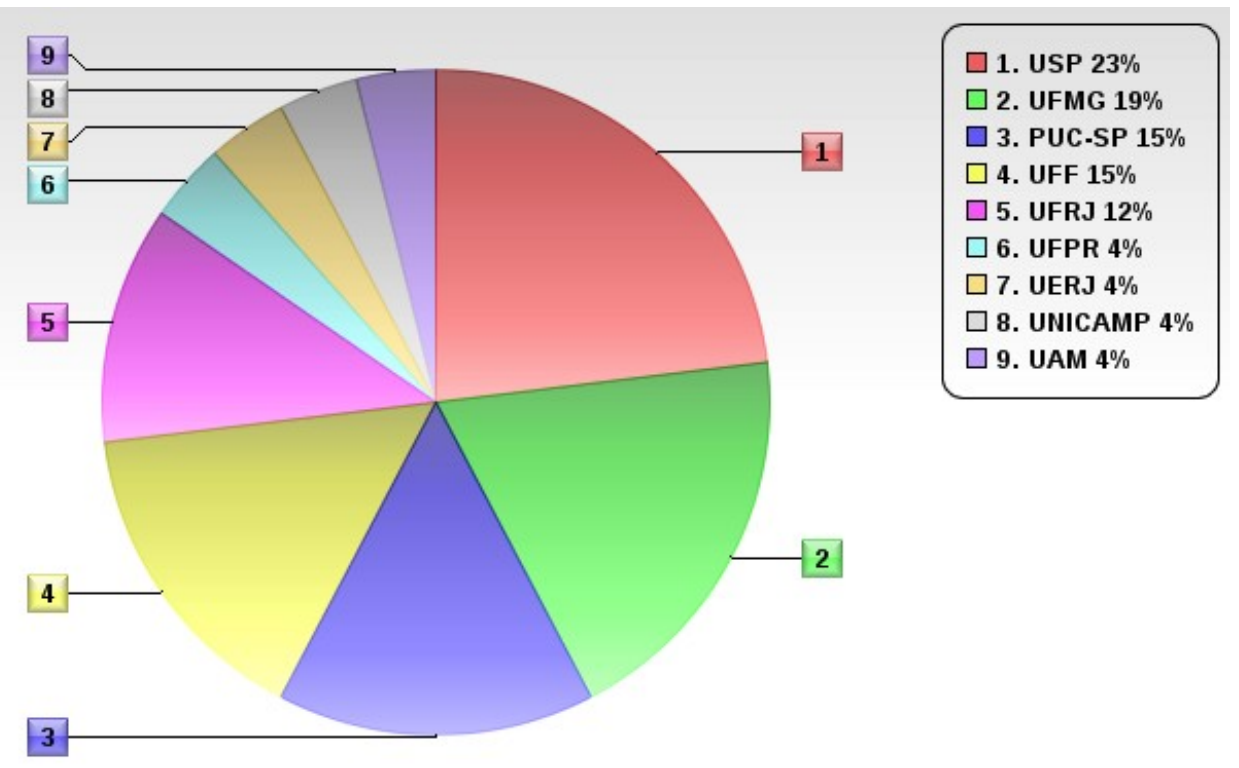

Incorporadas às instituições de ensino, as pesquisas de mestrado e doutorado estão afiliadas aos programas de pós-graduação onde são desenvolvidas. Estes programas de pósgraduação estão associados a áreas de conhecimento as quais, segundo a Capes, apresentam uma hierarquização. Ou seja, os programas de pós-graduação estão inseridos em uma área específica, que por sua vez está inserida em uma grande área de conhecimento. Sendo assim, as teses e dissertações sobre o som no cinema aqui levantadas, enquadram-se em três grandes áreas de conhecimento, três áreas específicas e doze programas de pós-graduação, todos recomendados e reconhecidos pela Capes. São eles: 
TABELA III

Disposição de Grandes Áreas de conhecimento, Áreas e Programas de Pós-Graduação por Universidade:

\begin{tabular}{|c|c|c|}
\hline Grandes Áreas & Áreas & Programas de Pós-Graduação / Universidade \\
\hline \multirow{5}{*}{ Ciências Sociais Aplicadas } & \multirow{5}{*}{ Comunicação } & Ciências da Comunicação / USP \\
\hline & & Comunicação Social / UFMG e UERJ \\
\hline & & Comunicação / UFF e UAM \\
\hline & & Comunicação e Semiótica / PUC-SP \\
\hline & & Multimeios / UNICAMP \\
\hline \multirow[t]{2}{*}{ Linguística, Letras e Artes } & \multirow[t]{2}{*}{ Artes (Artes/Música) } & Artes / UFMG \\
\hline & & Música / UFRJ e UFPR \\
\hline \multirow{2}{*}{ Ciências da Saúde } & \multirow{2}{*}{ Fonoaudiologia } & Fonoaudiologia / PUC-SP \\
\hline & & Educação em Ciências e Saúde / UFRJ \\
\hline
\end{tabular}

Já a quantidade de teses e dissertações contida em cada área e programa de pósgraduação está demonstrada na tabela a seguir ${ }^{76}$ :

\section{TABELA IV}

Quantidade total de teses e dissertações por área e programa de pós-graduação:

\begin{tabular}{|c|c|c|c|c|}
\hline Área & Programas de Pós-Graduação/Universidade & Teses & Dissertações & Total \\
\hline \multirow{7}{*}{ Comunicação } & Ciências da Comunicação / USP & 2 & 4 & 6 \\
\hline & Comunicação / UFF & 1 & 3 & 4 \\
\hline & Comunicação e Semiótica / PUC-SP & 1 & 1 & 2 \\
\hline & Comunicação Social / UFMG & - & 1 & 1 \\
\hline & Comunicação Social / UERJ & - & 1 & 1 \\
\hline & Comunicação / UAM & - & 1 & 1 \\
\hline & Multimeios / UNICAMP & - & 1 & 1 \\
\hline \multirow{3}{*}{$\begin{array}{c}\text { Artes } \\
\text { (Artes/Música) }\end{array}$} & Artes / UFMG & 1 & 3 & 4 \\
\hline & Música / UFRJ & - & 2 & 2 \\
\hline & Música / UFPR & - & 1 & 1 \\
\hline \multirow{2}{*}{ Fonoaudiologia } & Fonoaudiologia / PUC-SP & - & 2 & 2 \\
\hline & Educação em Ciências e Saúde / UFRJ & - & 1 & 1 \\
\hline Total & - & 5 & 21 & 26 \\
\hline
\end{tabular}

Esses dados indicam que a área de Comunicação é a que abrange a maior quantidade de teses e dissertações defendidas entre os anos de 2001 e 2011 no país, contendo dezesseis trabalhos. E portanto, pode-se afirmar que é a área que possuiu relações de pesquisa mais próximas ao campo dos estudos brasileiros sobre o som cinematográfico. Em seguida, está a

76 Confira a lista bibliográfica de teses e dissertações distribuídas por Área e Programa de Pós-Graduação no Anexo IV deste trabalho. 
área de Artes (Artes/Música) com sete trabalhos, e depois, a de Fonoaudiologia com três. Em termos de porcentagem esses números representam os seguintes valores:

GRÁFICO IV

Porcentagem de teses e dissertações por Área:

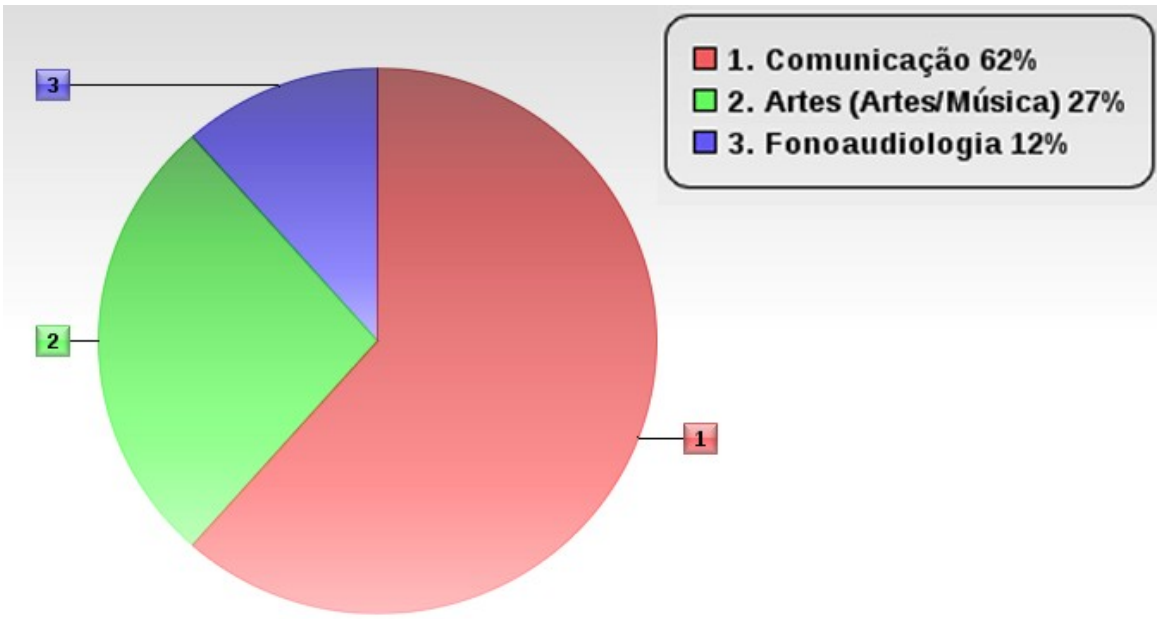

Para entender a pluralidade dos meios nos quais se desenvolveram as teses e as dissertações contemporâneas sobre o som no cinema, e buscar outras relações entre os dados apresentados, é necessário adentrar um pouco mais nas possíveis ligações acadêmicas existentes entre os trabalhos.

Os programas de pós-graduação costumam estar fragmentados em áreas de concentração, as quais são desdobradas em linhas de pesquisa. Porém, há casos em que os programas de pós-graduação se dividem somente em áreas de concentração, ou diretamente em linhas de pesquisa. Independente disso, é importante ressaltar que nessas "áreas" e "linhas" são onde estão situados os projetos de pesquisa desenvolvidos pelos docentes, os orientadores dos trabalhos, e pelos discentes, autores das teses e dissertações defendidas no programa. Assim, por delimitarem os campos de interesse e saberes relacionados aos pesquisadores desses programas, essas "áreas" e "linhas" podem revelar afinidades entre os estudos ou demais características da pesquisa brasileira contemporânea sobre o som no cinema .

Começando pelos programas de pós-graduação relacionados à área de Comunicação que, como pode ser notado, foram os mais procurados para o desenvolvimento das pesquisas contemporâneas sobre o som no cinema. E que aqui estão representados pelos Programa de Pós-Graduação de Ciências da Comunicação da USP, Comunicação da UFF e da UAM, Comunicação e Semiótica da PUC-SP, Comunicação Social da UFMG e UERJ, e Multimeios da UNICAMP. 
O Programa de Pós-Graduação em Ciências da Comunicação da USP concentra todas as duas teses e quatro dissertações presentes na instituição. Os quatro trabalhos de mestrado ${ }^{77} \mathrm{e}$ um de doutorado ${ }^{78}$ estão associados à Área de Concentração "Estudos dos Meios da Produção Mediática”. Apenas a tese de Luiz Adelmo Manzano (2005) que está relacionada à Área de Concentração “Comunicação e Estética do Audiovisual”. E mais, as quatro dissertações foram orientadas pelo Prof. Dr. Eduardo Santos Mendes, e as duas teses pela Prof ${ }^{\mathrm{a}}$. Dr ${ }^{\mathrm{a}}$. Maria Dora Mourão. Agora, ao averiguar as linhas de pesquisa desses orientadores, observa-se que o PPGCom da USP passou por reformulações ao longo dos onze anos estudados.

No processo de adequação dos programas de pós-graduação da Escola de Comunicação e Artes da USP, a área de concentração "Comunicação e Estética do Audiovisual” foi extinta no ano de 2005. Isso esclarece o por quê da tese de Luiz Adelmo Manzano pertencer a uma área de concentração diferente da do trabalho de doutorado de João Godoy Souza (2011), e ainda assim contar com a mesma orientadora. Em 2006 foi quando surgiu a área "Estudos dos Meios da Produção Mediática”, a qual Mendes e Mourão pertenceram até o ano de 2009. Em 2009, foi então constituído um novo programa de pós-graduação mais direcionado para as pesquisas relacionadas ao cinema, à televisão, ao rádio, ao vídeo e às mídias digitais, denominado Programa de Pós-Graduação em Meios e Processos Audiovisuais (PPGMPA).
A criação do Programa de Pós-Graduação em Meios e Processos Audiovisuais é resultado de um legado de pesquisa histórica e estética desenvolvido ao longo das últimas três décadas por professores e pesquisadores associados às várias fases pelas quais passou a área de concentração dedicada aos estudos de cinema, rádio e televisão. O mestrado em rádio e televisão foi o primeiro a ser criado, em 1972, logo seguido em 1974 pelo mestrado em cinema e teatro. Em 1980, foi criado o doutorado em ambos os cursos. Reformulações gerais do programa implantadas em 1996 consolidaram os dois cursos em uma só área de concentração do programa de pós- graduação em Ciências da Comunicação, a bem sucedida área de Comunicação e Estética do Audiovisual. A partir do ano de 2009, e no espírito de colaborar com o esforço de reformulação e adequação de programas de pós-graduação e áreas de conhecimento em curso na Escola de Comunicações e Artes e nas agências nacionais de financiamento, professores atuantes na docência e na pesquisa relacionada ao cinema, à televisão, ao rádio, ao vídeo e às mídias digitais propõem a constituição desse novo programa, que reúne aspectos artísticos e industriais, teóricos e práticos da área audiovisual. ${ }^{79}$

Como o PPGMPA foi criado em 2009, tendo seus primeiros projetos de mestrado e doutorado iniciados em 2010, não houve tempo hábil para dissertações e teses serem

\footnotetext{
77 O de Mariano Alvarez (2007), Tide Borges Guimarães (2008), de Ana Luiza Barbosa (2009) e de Kira Pereira (2010).

78 O de João Godoy Souza (2011).

79 Informações retiradas do site do PPGMPA da ECA/USP. Disponível em:

$<$ http://www.pos.eca.usp.br/index.php?q=en/node/309>. Acesso em 20 janeiro de 2013.
} 
finalizadas até $2011^{80}$.

Voltando às linhas de pesquisa, por conta da ausência de informações sobre elas nos trabalhos, e diante a atualização do site, dos regulamentos e dos editais dos programas de pósgraduação da ECA/USP, não foi possível encontrar mais detalhes sobre as linhas de pesquisa onde essas teses e dissertações foram realizadas na época. A informação que existe é que atualmente Eduardo Santos Mendes e Maria Dora Mourão desenvolvem seus projetos de orientação na linha intitulada "Poéticas e Técnicas".

A linha de pesquisa Poéticas e Técnicas reúne professores dedicados ao estudo e experimentação dos modos de proceder na realização de obras audiovisuais, seja na contemporaneidade ou na história dos meios audiovisuais, com ênfase para a relação entre técnicas e competências específicas de criação, nos planos de elaboração de roteiros, montagem, captação e edição de som, animação de imagens, direção e organização da produção, considerando suportes analógicos e digitais. ${ }^{81}$

No site do PPGMPA é indicado que o projeto de pesquisa de Eduardo Santos Mendes desenvolvido na pós-graduação é sobre a relação diretor/sound designer na construção da trilha sonora, e o de Maria Dora Mourão sobre a incidência da tecnologia na linguagem cinematográfica a partir da montagem como processo criativo ${ }^{82}$.

O Programa de Pós-Graduação em Comunicação da UFF também concentra a tese ${ }^{83}$ e as três dissertações ${ }^{84}$ presentes na universidade. Destas, apenas a dissertação de Ivan Capeller (2005) é orientada pela Prof ${ }^{\mathrm{a}}$. Dr ${ }^{\mathrm{a}}$. Maria Cristina Franco Ferraz. Os demais trabalhos são de orientação do Prof. Dr. João Luiz Vieira. As informações sobre a área de concentração ou linha de pesquisa desses materiais não constam indicadas nos trabalhos, salvo exceção da dissertação de Andreson Carvalho (2009) que aponta estar associada à área de concentração “Análise da Imagem e do Som". Investigando as "áreas" e "linhas" dos dois orientadores, nota-se porém que a área "Análise da Imagem e do Som" não existe mais. Inclusive, atualmente o PPGCom da UFF está dividido diretamente em torno de três linhas de pesquisa, não possuindo portanto, a integração com áreas de concentração. Mas não foram encontradas mais informações acerca de um possível processo de restruturação do programa. Apenas que atualmente o orientador João Luiz Vieira está associado à linha de pesquisa "Estudos de Cinema e Audiovisual".

\footnotetext{
80 Apenas no ano de 2013 que começam a aparecer os primeiros trabalhos sobre som no cinema provenientes do PPGMPA da USP. A exemplo da dissertação "As dimensões reais e imaginárias do som nos filmes de Licrecia Martel” (CUNHA, 2013), e deste próprio trabalho de mestrado.

81 Informações retiradas do site do PPGMPA da ECA/USP. Disponível em: $<\mathrm{http}$ :/www.pos.eca.usp.br/index.php?q=en/node/309>. Acesso em 20 janeiro de 2013.

82 Informação disponível no link: <http://www.pos.eca.usp.br/index.php?q=en/node/315>. Acesso em 20 janeiro de 2013.

83 A de Fernando Morais da Costa (2006).

84 A de Ivan Capeller (2005), Andreson Carvalho (2009) e de Fernando Morais da Costa (2003a).
} 
A linha centra seu foco de interesse nas análises que articulam distintas abordagens em relação ao cinema e ao audiovisual, com ênfase nos processos políticos e subjetivos através dos quais esses campos se constituem. Nesse sentido, o universo do audiovisual se apresenta como uma arena de problematização da esfera midiática, que permite investigações com aportes estéticos, econômicos, históricos e narrativos, articulando-o sobretudo como um campo teórico. ${ }^{85}$

No site do PPGCom da UFF há a informação de que atualmente João Luiz Vieira desenvolve pesquisa sobre "O corpo do voyer: Alair Gomes e Djalma Batista" ${ }^{86}$. Sobre a orientadora Maria Cristina Franco Ferraz, consta em seu currículo Lattes que aposentou da UFF em abril de 2011 e que, nesta instituição, desenvolveu pesquisas diante as seguintes linhas: "Linguagem e Poder", "Controle e Tecnologia do Virtual" e "Representação no Ocidente". Mas a informação precisa sobre a linha de pesquisa do trabalho de mestrado de CAPELLER (2005) não foi obtida.

No Programa de Pós-Graduação em Comunicação e Semiótica da PUC-SP estão presentes dois trabalhos, uma tese e uma dissertação, ambos de Elen Döppenschmitt (2010; 2005) e orientados pela Prof $f^{\mathrm{a}}$. Dr ${ }^{\mathrm{a}}$. Jerusa Piris Ferreira. A área de concentração é denominada "Signo e Significação nas Mídias":

Compreende atividades científicas de pesquisa, ensino e orientação sobre sistemas de signos e processos de significação no campo dos fenômenos comunicacionais, em especial no contexto das diversas mídias, entendidas em suas dimensões semióticas e inserções culturais, com as respectivas implicações epistemológicas, históricas, sociais e tecnológicas. (PONTIFÍCIA UNIVERSIDADE CATÓLICA DE SÃO PAULO, s. d.)

E a linha de pesquisa é a "Cultura e ambientes midiáticos" que abrange...

Estudos das relações entre a produção midiática e o contexto histórico e cultural, implicando-se, nesse recorte, as mediações e impactos sociais, políticos, cognitivos e tecnológicos na organização da vida cotidiana. Nessa perspectiva, investigam-se as relações entre comunicação e temporalidades, espacialidades, hibridismos, corporalidades, visualidades e intersubjetividades - temáticas consideradas nos níveis regional, nacional e/ou mundial. (PONTIFÍCIA UNIVERSIDADE CATÓLICA DE SÃO PAULO, s. d.)

O site do Programa de Pós-Graduação em Comunicação e Semiótica da PUC-SP ainda informa que o projeto de pesquisa de Jerusa Piris Ferreira é sobre "Tradição e transmissão oral: gestos, ambiente, comunicação" ${ }^{87}$.

85 Informações retiradas do site do Programa de Pós-Graduação em Comunicação da UFF. Disponível em: $<$ http://www.uff.br/ppgcom/?page_id=121>. Acesso em 20 março de 2013.

86 Informação disponível no link: <http://www.uff.br/ppgcom/?page id=1156>. Acesso em 20 janeiro de 2013.

87 Informação disponível no link: $<$ http://www4.pucsp.br/cos/download/projetos_pesquisa_docentes_2011_09_22/L1ProjetoJerusaFerreira.pdf $>$. Acesso em 20 janeiro de 2013. 
Na UFMG, o Programa de Pós-Graduação em Comunicação Social contém apenas a dissertação de Pedro Aspahan (2008), orientada pelo Prof. Dr. Cesar Geraldo Guimarães, e que faz parte da área de concentração "Comunicação e Sociabilidade Contemporânea".

A área de concentração do PPGCom/UFMG - Comunicação e Sociabilidade Contemporânea - demarca o interesse na investigação da dimensão relacional da comunicação, seus processos de interlocução e suas interfaces interativas na vida social, abrangendo a preocupação com perspectiva interacional da comunicação, através de seus componentes materiais, simbólicos e sociais. ${ }^{88}$

Em relação à linha de pesquisa, é verificado que na capa da dissertação está indicada a denominada "Meios e Produtos da Comunicação". Porém, ao pesquisar o vínculo de pesquisa do orientador, nota-se que hoje ele está associado à linha de pesquisa "Pragmáticas da Imagem", interessado nas áreas de cinema moderno, experiência estética e discursos midiáticos. Neste caso também não foram encontradas mais informações acerca de um possível processo de restruturação do programa. Sobre a linha de pesquisa "Pragmáticas da Imagem":

Esta linha de pesquisa aborda os procedimentos de criação, os modos de expressão e as formas de fruição das imagens, tendo em vista a especificidade dos dispositivos, discursos e performances que as produzem, assim como sua hibridação. A linha abriga a reflexão sobre a produção imagética, atentando-se para seus aspectos documentais, ficcionais ou plásticos. Levando-se em conta a dimensão pragmática que é intrínseca e coextensiva à dimensão opressiva das imagens, procura-se compreender as mediações pelas quais elas instauram experiências subjetivas, políticas e estéticas. ${ }^{89}$

No site do PPGCom da UFMG há também a informação de que atualmente o projeto de pesquisa do orientador Cesar Geraldo Guimarães é sobre "Imagens de fora: transformações midiáticas no cinema contemporâneo"90.

O Programa de Pós-Graduação em Comunicação Social da UERJ agrega uma dissertação, a de José Cláudio Castanheira (2010a), orientada pelo Prof. Dr. Vinícius Andrade Pereira, e que está vinculada à linha de pesquisa "Tecnologia de Comunicação e Cultura".

Esta linha dedica-se à investigação das articulações entre tecnologia, comunicação e cultura. As relações das tecnologias comunicacionais com o ordenamento das categorias sociais e do imaginário, com formações subjetivas e com a emergência de modos novos de perceber, de sentir e de conhecer, constituem o eixo central a partir do qual as discussões e pesquisas estruturam-se. São privilegiadas na reflexão algumas tendências da comunicação contemporânea (modelos digitais, redes, processos de simulação, mobilidade), sem prejuízo, contudo, dos estudos de outras

88 Informações retiradas do site do Programa de Pós-Graduação em Comunicação Social da UFMG. Disponível em: <http://www.fafich.ufmg.br/dcs/pos-graduacao/t7>. Acesso em 20 março de 2013.

89 Informações retiradas do site do Programa de Pós-Graduação em Comunicação Social da UFMG. Disponível em: <http://www.fafich.ufmg.br/dcs/pos-graduacao/t11>. Acesso em 20 março de 2013.

90 Informação disponível no link: <http://www.fafich.ufmg.br/dcs/pos-graduacao/t19/1/cesar-geraldoguimaraes-1/>. Acesso em 23 jan. de 2013. 
estruturas e sistemas de comunicação. Trata-se, em última instância, de investigar os impactos materiais, as configurações afetivo-cognitivas $\mathrm{e}$ as repercussões socioculturais das diferentes tecnologias comunicacionais nos contextos de sua produção, utilização e difusão. ${ }^{11}$

Não foram encontradas informações sobre o projeto de pesquisa desenvolvido pelo orientador nessa pós-graduação.

No Programa de Pós-Graduação em Comunicação da UAM está presente a dissertação de Mauricio Esposito (2011), orientada pelo Prof. Dr. André Gatti, e que fez parte da área de concentração "Comunicação Contemporânea". No site do PPGCom da UAM há a informação de que esta área de concentração foi renomeada atualmente para "Comunicação Audiovisual" a qual concentra duas linhas de pesquisa: "Análise de Produtos Audiovisuais" e "Processos Midiáticos na Cultura Audiovisual". Porém, no currículo Lattes de André Gatti é informado que este realizou atividades de orientação na UAM apenas entre os anos de 2009 e 2011. Como as informações do site do PPGCom da UAM estão atualizadas, e não há mais informações na dissertação sobre isso, não foi possível encontrar qual a linha de pesquisa o orientador e o trabalho de mestrado estavam situados na época do desenvolvimento da pesquisa. Porém, ao observar o conteúdo da dissertação Mauricio Esposito (2011) pressupõese que estaria mais próxima da linha de pesquisa "Análise de Produtos Audiovisuais”, como pode ser observado:

A linha ["Análise de Produtos Audiovisuais"] se apóia nas múltiplas variantes da vertente analítica, a qual, aplicada ao estudo de produtos audiovisuais, permite que as pesquisas se situem e se movimentem dentro do universo do reconhecimento dos modos e formas de expressão que configuram a comunicação audiovisual. Os objetos desta linha são os produtos audiovisuais (filmes, programas de tevê, vídeos, sites de internet etc.), entendidos como conteúdos configurados em imagem e som, e submetidos aos mais variados tipos de análises (estéticas, poéticas, históricas, narrativas etc.).

A linha ["Processos Midiáticos na Cultura Audiovisual"] se apóia no movimento de relação dos processos midiáticos com a cultura especificamente configurada pelo universo da imagem e do som, permitindo que sejam estudados os fenômenos de midiatização apenas no tipo específico de cultura que viceja no campo da comunicação audiovisual. Os objetos desta linha são os processos midiáticos situados no âmbito de suas relações com a dinâmica da cultura audiovisual. ${ }^{92}$

E na UNICAMP, o Programa de Pós-Graduação em Multimeios reúne apenas a dissertação de Natalia Barrenha (2011), orientada pelo Prof. Dr. Antonio Fernando da

91 Informações retiradas do site do Programa de Pós-Graduação em Comunicação Social da UERJ. Disponível em: <http://www.ppgcom.uerj.br/area_concentracao.php>. Acesso em 20 março de 2013.

92 Informações disponíveis no link: $<\overline{\mathrm{http}}$ ://portal.anhembi.br/estude-aqui/pos-graduacao/cursos/mestrado-emcomunicacao/estrutura-do-programa/areas-de-concentracao-e-linhas-de-pesquisa/>. Acesso em 23 jan. de 2013. 
Conceição Passos. Não foram encontradas informações sobre a área de conhecimento ou a linha de pesquisa do trabalho. Porém, nota-se que o Programa de Pós-Graduação em Multimeios da UNICAMP está concentrada atualmente apenas em uma linha de pesquisa, a denominada "História, Estética e Domínios de Aplicação do Cinema e da Fotografia” que...

Concentra projetos de pesquisa que buscam a reflexão teórica sobre a história do cinema e da fotografia, explorando a produção nacional e internacional, e dando destaque a seus procedimentos criativos e metodológicos, bem como a suas dimensões autorais. Explora também as possibilidades cognitivas das imagens fixas e animadas nos processos de investigação das ciências humanas. O território acadêmico se estende, portanto, do cinema documentário ao cinema de ficção, passando pelo vídeo-arte, incluindo os campos da fotografia documentária e contemporânea e das poéticas experimentais. ${ }^{93}$

O projeto de pesquisa realizado pelo orientador Antonio Fernando da Conceição Passos atualmente é sobre cinema e literatura, como consta no site do Programa de Pós-Graduação em Multimeios da UNICAMP ${ }^{94}$.

Já os programas de pós-graduação relacionados à área de Artes (Artes/Música), que estão em segundo lugar em termos de quantidade de trabalhos neles desenvolvidos, aqui são representados pelos programas de Artes da UFMG e de Música da UFRJ e UFPR.

O Programa de Pós-Graduação em Artes da UFMG concentra uma tese e três dissertações, todas fazendo parte da área de concentração "Tecnologia da Imagem", e situando-se na linha de pesquisa "Criação e Crítica da Imagem em Movimento", a qual enfoca tanto o trabalho teórico sobre arte, quanto a conjugação entre teoria e práxis artística através da produção e reflexão sobre o trabalho produzido.

As áreas dessa Linha [cinema e artes digitais] contemplam os seguintes campos: Linguagem e Dramaturgia Cinematográficas; Imagem como Documento; Tecnologias da Imagem; Teoria Crítica do Imaginário e Estratégias Narrativas da Imagem; Arte Computacional. A produção acadêmica em cinema na pós-graduação abrange ainda o universo das imagens sintéticas. ${ }^{95}$

A tese de Daniel Werneck (2010) e a dissertação de Nélio Costa (2004a) foram orientadas pelo Prof. Dr. Heitor Capuzzo Filho. Não foram encontradas informações sobre o projeto de pesquisa desenvolvido por esse orientador nessa instituição. Apenas consta em seu currículo Lattes que não exerce mais atividades docentes na UFMG desde o ano de 2011. E as dissertações de Márcio Cardoso Marcolino (2008) e de Frederico Pessoa (2011), orientadas

93 Informação retirada do site do Programa de Pós-Graduação em Multimeios da UNICAMP. Disponível em: $<\mathrm{http}$ ://www.iar.unicamp.br/posgraduacao/multimeios.php>. Acesso em 20 março de 2013.

94 Informação disponível no link: < http://www.iar.unicamp.br/docentes/fernandopassos/>. Acesso em 23 jan. de 2013.

95 Informação retirada do site do Programa de Pós-Graduação em Artes da UFMG. Disponível em: $<$ http://www.eba.ufmg.br/pos/?page_id=8>. Acesso em 20 março de 2013. 
pelo Prof. Dr. Jalver Bethônico, o qual desenvolve projetos sobre cinema e relações imagem e som.

A Pós-Graduação em Música da UFRJ reúne duas dissertações, a de Virgínia Flores (2006) e a de Alexandre Bräutigam (2007), ambas orientadas pelo Prof. Dr. Rodolfo Caesar. A área de concentração desses trabalhos é a denominada "Musicologia".

A formação de Mestrado stricto sensu em Música na área de concentração Musicologia tem como objetivos desenvolver a capacidade de investigação e discussão do fenômeno musical em suas diversas dimensões e manifestações, seja com ênfase histórica, etnográfica ou teórica, proporcionando o desenvolvimento da capacidade de reflexão, discussão e contextualização do fato musical, através de pesquisa científica e produção de dissertação elaborada com base em critérios metodológicos fundamentados. ${ }^{96}$

E a linha de pesquisa é "Sonologia", que investiga o som musical compreendido como fenômeno multidisciplinar e multidimensional, envolvendo aspectos psicológicos, físicos, fisiológicos e estéticos. Nota-se que o projeto de pesquisa atual do orientador, intitulado "Música, Imagem e Sonologia: entre a escuta e outros sentidos", é um pouco diferente do que era desenvolvido no período de produção das dissertações de FLORES (2006) e de BRÄUTIGAM (2007). Tanto o motivo da modificação do projeto, quanto o significado do termo "sonologia", estão explicados na citação a seguir:

Entre o projeto anterior a este (com término em 02/09), a incidência de uma significativa alteração no título deve ser apresentada e discutida. Os projetos têm propósito conseqüente e convergente: permanece o tema 'escuta e outros sentidos', porém o novo pretenderá aprofundar a substituição da ênfase em 'tecnologia' pela em sonologia. Isto não se deve a uma consideração menor por tecnologia, mas por duas razões: a primeira pelo fato que - nestes tempos em que as 'novas' tecnologias deixaram-se absorver em nosso cotidiano - ela se torna mais ferramenta de pesquisa que tema para investigação. Portanto ela não mais servirá ao propósito deste projeto como tema central, mas como um dentre os demais tópicos abordados pela pesquisa, agora reunidos em 'sonologia'. [...] A segunda razão concerne à ampliação do escopo da investigação, inscrevendo-a em campo sonológico. Entende-se sonologia como importante campo musicológico, entrecruzando desde a audio culture norte-americana (voltada para investigações de cunho cultural) até a sonología espanhola (mais voltada para aplicativos e software: www.esmuc.net/sonologia/) e a sonologie belga (mais interessada em modelos perceptivos e cognitivos: www.koncon.nl/public_site/220/Sononieuw/). Em pesquisas descritas em textos recentes, constatei cada vez mais a ruptura de fronteiras entre a experiência acústica e as outras pertencentes aos outros sentidos, aumentando ainda mais a complexidade da enunciação do problema. A pesquisa versará sobre esta abrangência, tomando a composição como modelo e método. Uma visada cultural aponta para a abertura das possibilidades artísticas se manifestarem em formas e formatos mais intersticiais que as formas e formatos consagrados pela cultura oficial (música, teatro, artes plásticas, cinema, etc.), pela indústria cultural e pela opinião pública. [...] Assim, a pesquisa

96 Informação retirada do site do Programa de Pós-Graduação em Música da UFRJ. Disponível em: $<$ http://www.musica.ufrj.br/posgraduacao/index.php?

option=com_content\&view=article\&id=348\&Itemid=202>. Acesso em 20 março de 2013. 
pretende empreender incursões ao encontro de situações nas quais o relacionamento entre os sentidos problematiza os caminhos aceitos por formas de conhecimento pouco adequadas ao entendimento de obras musicais ou artísticas em geral. ${ }^{97}$

O Programa de Pós-Graduação em Música da UFPR agrega apenas uma dissertação, a de Débora Opolski (2009) orientada pelo Prof. Dr. Norton Dudeque. Não há no trabalho informações acerca da área e da linha de pesquisa, porém observa-se no site do programa que a área de concentração a qual faz parte o orientador Norton Dudeque atualmente é a "Interpretação/Processos Criativos", e a linha de pesquisa é a "Teoria, Criação Musical e Estética Musical".

A linha de pesquisa Teoria e Criação Musical é destinada a profissionais que desenvolvam atividades pedagógicas e de pesquisa em composição, teoria e análise musical. As disciplinas específicas da linha de pesquisa envolvem aspectos criativos, teóricos e analíticos da literatura musical. Projetos de pesquisa para esta linha devem privilegiar pesquisas de caráter composicional, estudos teórico/analíticos de aspectos, e obras de determinados compositores, preferencialmente nacionais. ${ }^{98}$

$\mathrm{Na}$ época em que o mestrado de Débora Opolski foi desenvolvido, o orientador Norton Dudeque participava do projeto "Leitura, Escuta e Interpretação: estudos de Performance Musical"99.

Partindo para os últimos programas de pós-graduação apontados, estão aqueles relacionados à área de Fonoaudiologia, aqui representados pelos cursos de Fonoaudiologia da PUC-SP e de Educação em Ciências e Saúde da UFRJ.

No Programa de Pós-Graduação em Fonoaudiologia da PUC-SP estão presentes as dissertações de Priscila Haydée Souza (2010) e a de Vitória Amaral (2006), ambas orientadas pela Prof ${ }^{a}$. Dr ${ }^{a}$. Léslie Piccolotto Ferreira. Novamente não há nos trabalhos informações acerca da área e da linha de pesquisa, porém observa-se no site do programa que a área de concentração a qual faz parte o orientadora Léslie Piccolotto Ferreira, atualmente é a denominada "Clínica Fonoaudiológica", e a linha de pesquisa, a "Voz: avaliação e intervenção".

A linha de pesquisa em 'Voz: avaliação e intervenção' tem como objetivo estudar as relações entre as dimensões orgânica, psíquica e sócio-cultural da voz, em contexto de uso profissional, predominantemente. Esta Linha de Pesquisa tem suas atividades centradas nos estudos e pesquisas sobre voz, considerando as atuações clínicas e de

\footnotetext{
97 Informação retirada do site do Programa de Pós-Graduação em Música da UFRJ. Disponível em: $<$ http://www.musica.ufrj.br/posgraduacao/index.php? option=com_content\&view=article\&id=435\&Itemid=205>. Acesso em 26 março de 2013.

98 Informação retirada do site do Programa de Pós-Graduação em Música da UFPR. Disponível em: $<$ http://www.humanas.ufpr.br/portal/artes/pos-graduacao/areas-de-concentracao-linhas-de-pesquisa/ $>$. Acesso em 26 março de 2013.

99 Informação disponível no link: <http://www.humanas.ufpr.br/portal/artes/pos-graduacao/projeto-depesquisa/>. Acesso em 23 jan. de 2013.
} 
assessoria do fonoaudiólogo. ${ }^{100}$

Durante o período que engloba o desenvolvimento dos mestrados de Priscila Haydée Souza (2010) e a de Vitória Amaral (2006), a orientadora participava do projeto "Voz: uma dimensão de sua representação no cotidiano"101.

E no Programa de Pós-Graduação em Educação em Ciências e Saúde da UFRJ está a dissertação de Luciana Castro (2001), orientada pela Prof ${ }^{\mathrm{a}}$. Dr ${ }^{\mathrm{a}}$. Anita Leandro, e fazendo parte da linha de pesquisa "Tecnologia Educacional nas Ciências e na Saúde", a qual...

Investiga a inserção das tecnologias da informação e comunicação (TICs) em contextos educativos na sociedade contemporânea, em particular, na construção de modelos e metodologias de representação e estruturação do conhecimento, na aprendizagem e no desenvolvimento cognitivo. ${ }^{102}$

Não foram encontradas informações sobre o projeto de pesquisa desenvolvido pela orientadora nesse programa.

Cabe aqui destacar a dificuldade em obter informações precisas sobre quais de fato eram as áreas, as linhas e os projetos de pesquisa dos orientadores dos trabalhos no período em que estes eram desenvolvidos. Seja pela falta de hábito dos autores em assinalá-las nas capas ou "folhas de rosto" dos próprios trabalhos, ou também pelo fato dessas informações estarem em contínua atualização. Informações que hoje, em um primeiro momento, parecem estar acessíveis apenas por meio dos conteúdos dos sites, dos regulamentos ou editais dos programas de pós-graduação. Há também informações nos currículos Lattes dos orientadores, porém constatou-se que na maioria das vezes estas não estão em plena sintonia com as dos sites dos programas, indicando nomenclaturas diferentes, por exemplo. De qualquer forma, percebe-se que grande parte desses programas de pós-graduação estão em constante reformulação com a intenção de se atualizarem e se adequarem à evolução dos campos e temas de estudos.

Apesar da dificuldade em resgatar essas informações, é possível notar que entre os projetos de pesquisa mencionados, o do Prof. Dr. Eduardo Santos Mendes da USP é o que está mais relacionado direto e especificamente com a vertente dos Film Sound Studies. Com vínculos próximos aos estudos do som no cinema, pode-se aferir aqueles orientadores que estão ou estiveram ligados ao campo dos Film Studies, como os Profs. Drs. Jalver Bethônico

${ }^{100}$ Informação retirada do site do Programa de Pós-Graduação em Fonoaudiologia da PUC-SP. Disponível em: $<\mathrm{http} / /$ www.pucsp.br/pos/fonoaudiologia/programa/linhas_pesquisa.html >. Acesso em 26 março de 2013.

101 Informação disponível no link: http://www.pucsp.br/pos/fonoaudiologia/downloads/defesas/Projetos \%202012.pdf>. Acesso em 23 jan. de 2013.

${ }^{102}$ Informação retirada do site do Programa de Pós-Graduação em Educação em Ciências e Saúde da UFRJ. Disponível em: <http://www.nutes.ufrj.br/mestrado/>. Acesso em 26 março de 2013. 
e Heitor Capuzzo Filho da UFMG, o Prof. Dr. João Luiz Vieira da UFF, a Prof ${ }^{\mathrm{a}}$. Dra ${ }^{\mathrm{a}}$. Maria Dora Mourão da USP, o Prof. Dr. André Gatti da UAM, e o Prof. Dr. Antonio Fernando da Conceição Passos da UNICAMP. Já de certa forma relacionados ao abrangente campo dos Sound Studies, estão os dois orientadores da área da música, o Prof. Dr. Norton Dudeque da UFPR e o Prof. Dr. Rodolfo Caesar da UFRJ. Sendo que esse último chegou a ampliar seu projeto de pesquisa após o término de suas duas orientações de mestrado, incorporando a arte cinematográfica como objeto de estudo da "sonologia". Os outros orientadores estão associados a áreas diversas como a da comunicação e da fonoaudiologia, a exemplo do Prof. Dr. Cesar Geraldo Guimarães da UFMG, da Prof ${ }^{a}$. Dr ${ }^{\mathbf{a}}$. Maria Cristina Franco Ferraz da UFF, da Prof ${ }^{\mathrm{a}}$. Dr ${ }^{\mathrm{a}}$. Jerusa Piris Ferreira da PUC-SP, do Prof. Dr. Vinícius Andrade Pereira da UERJ, da Prof ${ }^{\mathrm{a}}$. Dr ${ }^{\mathrm{a}}$. Léslie Piccolotto Ferreira da PUC-SP e da Prof ${ }^{\mathrm{a}}$. Dr ${ }^{\mathrm{a}}$. Anita Leandro da UFRJ.

Desta maneira, percebe-se no Brasil uma carência na quantidade de orientadores relacionados ao campo específico dos estudos do som cinematográfico. Além disso, mesmo Eduardo Santos Mendes, um dos primeiros doutores especializados em som para cinema no país, sendo também quem mais orientou no período, computando quatro dissertações, não esteve até então credenciado para orientar projetos de doutorado, por exemplo. Logo, leva-se a crer que esta carência é a responsável por influenciar os pesquisadores, interessados em desenvolver trabalhos de mestrado e doutorado sobre som no cinema, a buscarem orientadores de outros campos e áreas de estudo.

Por outro lado, a diversidade de áreas de concentração, linhas e projetos de pesquisa as quais as teses e as dissertações estão ou estavam associadas, representa uma multiplicidade temática oferecida nos programas de pós-graduação, e uma multiplicidade de interesses particulares de estudo dos orientadores. Isso comprova a qualidade interdisciplinar presente no campo dos estudos sobre o som no cinema também no Brasil, fazendo desse campo de pesquisa um veículo de interação entre as áreas. Esta multiplicidade demonstra também uma certa flexibilidade das áreas de concentração, linhas e projetos de pesquisa dos orientadores ao receberem essas pesquisas de mestrado e doutorado que também envolvem contextos diversificados, como pode ser visto no item anterior sobre as "Tendências Temáticas". Desta forma, é possível notar que houve, portanto, interesse principalmente por parte dos orientadores, em expandir essas áreas, tanto a de Comunicação quanto a de Artes (Artes/Música), como até a de Fonoaudiologia. Mesmo sendo áreas abrangentes, provam que é possível fazer relações entre suas especificidades ou focos temáticos e o universo sonoro do cinema. $\mathrm{O}$ interesse por parte dos orientadores pode ser compreendido principalmente por 
haver pesquisas em determinadas universidades e programas de pós-graduação que se concentram em certos docentes. Além do Prof. Dr. Eduardo Santos Mendes da USP que orientou quatro dissertações, e do Prof. Dr. Rodolfo Caesar da UFRJ que orientou duas, outros exemplos de convergência de orientação de pesquisas podem ser verificados no caso da Prof ${ }^{a}$. Dr ${ }^{\mathrm{a}}$. Maria Dora Morão, também da USP, que orientou duas teses; da Prof ${ }^{\mathrm{a}}$. Dr ${ }^{\mathrm{a}}$. Léslie Piccolotto Ferreira da PUC-SP, que orientou duas dissertações; do Prof. Dr. João Luiz Vieira da UFF, que orientou uma tese e duas dissertações; do Prof. Dr. Heitor Capuzzo Filho da UFMG, que orientou uma tese e uma dissertação; e do Prof. Dr. Jalver Bethônico, também da UFMG, que orientou duas dissertações.

Esta análise pode ser uma possível justificativa para entender o por quê da USP, da UFMG, da PUC-SP, da UFF e da UFRJ centralizarem a maior quantidade de teses e dissertações no período. Ou seja, muito provável que isto aconteceu pelo fato de associados a estas universidades estarem os orientadores mais procurados pelos pesquisadores para desenvolverem as pesquisas sobre o som no cinema aqui delimitadas.

Já em relação aos sessenta e quatro artigos levantados, observam-se trinta e seis locais onde eles foram publicados. Sendo que oito artigos foram publicados em livros de encontros, dez em anais de encontros, quarenta e quatro em revistas acadêmicas, um em um caderno de coleção e outro em um portal de pesquisa online ${ }^{103}$. Em especial, destacam-se dois desses locais de publicação. O primeiro são os livros lançados pela SOCINE, que refletem os encontros nacionais dessa sociedade fundamental para o progresso e o intercâmbio dos estudos de cinema e, consequentemente, dos estudos do som cinematográfico no país. Como já dito ao longo do item "Evolução Quantitativa", é na SOCINE que existe desde 2009 um seminário temático voltado exclusivamente para os estudos do som no cinema e no audiovisual.
A Socine promove encontros anuais que se configuram atualmente como o espaço mais importante para a divulgação e o debate dos mais recentes estudos e pesquisas voltados para as manifestações do fenômeno cinematográfico e áreas afins. O encontro anual é também parte do esforço da entidade em propiciar oportunidades concretas de interação entre os profissionais, produtores, críticos, pesquisadores, professores e estudantes do campo do audiovisual das diferentes regiões do país. Nesse sentido, é de fundamental importância a publicação anual da Socine, com uma proposta editorial seletiva e representativa dos trabalhos apresentados no encontro. ${ }^{104}$

E o segundo destaque vai para a edição de número 24 de 2011 da revista Ciberlegenda, vinculada ao Programa de Pós-Graduação em Comunicação da UFF. Esta foi a única revista

${ }^{103}$ Confira a lista bibliográfica de artigos distribuídos por local de publicação no Anexo VI deste trabalho.

${ }^{104}$ Informação retirada do site da SOCINE. Disponível em: <http://www.socine.org.br/quem.asp>. Acesso em 26 março de 2013. 
no período estudado que lançou uma edição dedicada unicamente ao debate sobre o som no cinema e em outras mídias. Como já foi mencionado no item "Evolução Quantitativa", a edição estava composta por dois volumes e ainda disponibilizou mais materiais em seu espaço online denominado "Estação Transmídia".

Devido tanto à quantidade como à excelente qualidade das contribuições recebidas nesta ocasião, temos o prazer de apresentar dois volumes simultâneos da publicação, lançando um rico conjunto de debates em torno do tema Mídia e Sonoridades. O primeiro volume, intitulado "Sonoridades - No cinema e no audiovisual", inclui 13 artigos que apresentam variadas discussões acerca do som nas produções audiovisuais modernas e contemporâneas: do hiper-realismo sonoro às representações e reapropriações da música e das "paisagens sonoras" pelas artes das telas. Este volume também compreende reflexões acerca do silêncio como produtor de sentido sobre o papel do som numa perspectiva histórica. Já o segundo volume articula 13 artigos em torno do grande tema "Sonoridades - Novas tecnologias estéticas". São apresentadas algumas questões relativas à produção sonora e audiovisual que circula pela internet, bem como às novas relações entre produção consumo de sons diante dos novos cenários tecnológicos, e às experiências estéticas nos contextos urbanos e hiperconectados da contemporaneidade. A ESTAÇÃO TRANSMÍDIA, por sua vez, contempla os trabalhos de vários pesquisadores convidados especialmente para contribuir com tais discussões, a partir da utilização de material de natureza diversas e em múltiplos suportes. (SIBILIA, 2011)

Dos sessenta e quatro artigos levantados, oito estão nos livros da SOCINE e dez na revista Ciberlegenda.

Diante das exposições contidas também nos itens sobre a "Evolução Quantitativa" e as "Tendências Temáticas", vale aqui mensurar que percebe-se um hábito dos pesquisadores publicarem artigos que aglutinam informações de suas teses ou dissertações. Cerca de vinte e sete textos levantados possuem alguma relação ou procedem de trabalhos de mestrado e doutorado dos autores. Esta é uma prática que facilita a difusão das ideias e discussões propostas nesses trabalhos maiores, muitas vezes menos acessíveis ou que exigem uma leitura mais densa. Já uma atividade pouco desenvolvida é a publicação em conjunto ou com coautoria. Neste caso, apenas seis artigos foram escritos com parceria entre autores.

Em relação aos autores envolvidos na pesquisa brasileira contemporânea sobre o som no cinema estudada, somam-se um total de cinquenta e um pesquisadores. Segue a tabela com a quantidade total de trabalhos publicados por autor ${ }^{105}$.

${ }^{105}$ Como artigos com co-autoria foram considerados mais de uma vez na tabela, o número total de materiais vai ser maior que o já computado. 
TABELA V

Quantidade total de livros, teses, dissertações e artigos publicados por autor e gênero:

\begin{tabular}{|c|c|c|c|c|c|}
\hline Nome & Livro & Teses & Dissertações & Artigos & TOTAL \\
\hline Fernando Morais da Costa & 1 & 1 & 1 & 12 & 15 \\
\hline José Cláudio Castanheira & - & - & 1 & 7 & 8 \\
\hline Eduardo Santos Mendes & - & - & - & 5 & 5 \\
\hline Elen Döppenschmitt & - & 1 & 1 & 3 & 5 \\
\hline Rodrigo Carreiro & - & - & - & 4 & 4 \\
\hline Kira Pereira & - & - & 1 & 2 & 3 \\
\hline Priscila Haydée & - & - & 1 & 2 & 3 \\
\hline Vitória Amaral & - & - & 1 & 2 & 3 \\
\hline Débora Opolski & - & - & 1 & 1 & 2 \\
\hline Fabiana Quintana & - & - & - & 2 & 2 \\
\hline Gerson Leme & - & - & - & 2 & 2 \\
\hline Ivan Capeller & - & - & 1 & 1 & 2 \\
\hline Léslie Piccolotto Ferreira & - & - & - & 2 & 2 \\
\hline Luiz Adelmo Manzano & 1 & 1 & - & - & 2 \\
\hline Márcia Carvalho da Silva & - & - & - & 2 & 2 \\
\hline Natalia Barrenha & - & - & 1 & 1 & 2 \\
\hline Ney Carrasco & - & - & - & 2 & 2 \\
\hline Virginia Flores & - & - & 1 & 1 & 2 \\
\hline Alexandre Bräutigam & - & - & 1 & - & 1 \\
\hline Alfredo Torres & - & - & - & 1 & 1 \\
\hline Aline Pedreiras & - & - & - & 1 & 1 \\
\hline Ana Luiza Barbosa & - & - & 1 & - & 1 \\
\hline André Gatti & - & - & - & 1 & 1 \\
\hline Andreson Carvalho & - & - & 1 & - & 1 \\
\hline Antônio Fernando Passos & - & - & - & 1 & 1 \\
\hline Bernardo Marquez Alves & - & - & - & 1 & 1 \\
\hline Consuelo Lins & - & - & - & 1 & 1 \\
\hline Damyler Cunha & - & - & - & 1 & 1 \\
\hline Daniel Werneck & - & 1 & - & - & 1 \\
\hline Federico Pessoa & - & - & 1 & - & 1 \\
\hline Isaac Pipano & - & - & - & 1 & 1 \\
\hline Ivonete Pinto & - & - & - & 1 & 1 \\
\hline João Godoy & - & 1 & - & - & 1 \\
\hline José Eduardo Bozicanin & - & - & - & 1 & 1 \\
\hline Luciana Castro & - & - & 1 & - & 1 \\
\hline Luciana Haussen & - & - & - & 1 & 1 \\
\hline Luciene Belleboni & - & - & - & 1 & 1 \\
\hline
\end{tabular}




\begin{tabular}{|c|c|c|c|c|c|}
\hline Luiza Alvim & - & - & - & 1 & 1 \\
\hline Márcio Marcolino & - & - & 1 & - & 1 \\
\hline Maria Laura Martz & - & - & - & 1 & 1 \\
\hline Mariano Gabriel Alvarez & - & - & 1 & - & 1 \\
\hline Mauricio Caleiro & - & - & - & 1 & 1 \\
\hline Mauricio Esposito & - & - & 1 & - & 1 \\
\hline Pedro Aspahan & - & - & 1 & - & 1 \\
\hline Rafael de Luna Freire & - & - & - & 1 & 1 \\
\hline Rafael Venancio & - & - & - & 1 & 1 \\
\hline Rodrigo Rodrigues & - & - & - & 1 & 1 \\
\hline Suzana Dobal & - & - & - & 1 & 1 \\
\hline Suzana Reck Miranda & - & - & - & 1 & 1 \\
\hline Tide Borges Guimarães & - & - & 1 & - & 1 \\
\hline Viviane Vedana & - & - & - & 1 & 1 \\
\hline
\end{tabular}

Observando os números totais, quem mais publicou foi o Prof. Dr. Fernando Morais da Costa da UFF, com um livro, uma tese, uma dissertação e doze artigos, computando quase o dobro de materiais do pesquisador José Cláudio Castanheira, o próximo em quantidade de publicações.

Vale ainda destacar que grande parte dos autores possuem experiência na prática profissional do mercado de realização audiovisual. Este é um dado empírico constatado pelo autor desta revisão sistemática que também vagueia profissionalmente entre o campo da pesquisa, do ensino e da prática de mercado. Para citar alguns exemplos: o Prof. Dr. Eduardo Santos Mendes além de ser professor do curso de Audiovisual da USP e de orientar projetos de mestrado no PPGMPA, atua como diretor de som, ou "projetista de som" como ele mesmo se designa, em filmes. O Prof. Dr. Luiz Adelmo Manzano, autor de um livro e uma tese aqui levantados, é supervisor de edição de som e mixador. O Prof. Dr. João Godoy, também professor do curso de Audiovisual da USP, é técnico de som direto. Bem como a professora do curso de cinema da FAAP, Tide Borges Guimarães. O Prof. Dr. da UFF Fernando Morais da Costa, atua também como técnico de som, editor e "desenhista de som". Virginia Flores, Débora Opolski, Kira Pereira e Ana Luiza Pereira também são professoras e editoras de som.

A partir dessas dados apresentados, pode-se afirmar que há na pesquisa brasileira contemporânea sobre o som no cinema uma forte integração entre o trabalho acadêmico e a prática do mercado de realização audiovisual. A complementação entre pesquisadores e profissionais de mercado através da troca e interação de experiências é recorrente no campo dos estudos do som. Como afirma a pesquisadora Elisabeth Weis, "uma das alegrias de se 
trabalhar com os estudos do som é que há um amplo intercâmbio de ideias entre os profissionais da área e os acadêmicos"106 (WEIS, 1999: 96). McGILL também constata:

Há de fato um maior diálogo entre os interessados no estudo crítico da trilha sonora e as pessoas envolvidas em sua produção real: dois grupos que até os últimos anos pareciam estar desconectados. [...] Este diálogo é indicativo de uma maior e importante troca interdisciplinar, algo que pode enriquecer a nossa compreensão da trilha sonora em vários níveis. Essa troca pode iluminar como os vários componentes do som do filme são criados e coordenados, e a natureza das considerações técnicas e artísticas envolvidas neste processo. Ele pode oferecer percepções sobre a dinâmica de trabalho entre profissionais de som e o modo de trabalho na indústria do cinema, e também levar uma compreensão mais desenvolvida como a razão pela qual a trilha sonora de um filme em especial soa como é. ${ }^{107}$ (McGILL, 2008: 16)

No caso citado por Weis e McGill, essa integração entre academia e mercado ocorre entre profissionais diversos. Já no Brasil, uma parte considerável dos pesquisadores também atuam profissionalmente na área de realização audiovisual. Logo, os laços entre a pesquisa e o mercado são fortalecidos. Seja na reflexão teórica do próprio fazer cinematográfico, na expansão e no esclarecimento de técnicas de produção, na atualização de recursos tecnológicos e de fluxos de trabalho em práticas de ensino, no desenvolvimento de uma estrutura de pensamento narrativo mais sofisticada, em novos métodos de investigação e de construção de projetos, etc.

Uma última curiosidade notada é que há um certo equilíbrio em relação ao gênero dos pesquisadores. Vinte e sete são homens e vinte e quatro mulheres.

\footnotetext{
106 Tradução do autor.

107 Idem.
} 


\section{CONCLUSÃO}

O som cinematográfico não pode ser considerado um tema periférico na bibliografia em língua portuguesa sobre o universo dos estudos de cinema e audiovisual. No Brasil, o hábito e o interesse dos pesquisadores e profissionais do som em estudar teoricamente o seu campo de atuação vêm aumentando e, consequentemente, o surgimento de novos documentos e materiais redigidos - presentes principalmente na área acadêmica -, cresce em um fluxo até então inédito. A pesquisa brasileira sobre o assunto, que chegou no final do século passado com pouca representatividade, tem nos primeiros onze anos do século XXI, e nos noventa e dois materiais analisados, a demonstração de que este campo de estudo já é digno de ser reconhecido também no país.

O levantamento bibliográfico realizado neste trabalho tentou ser o mais completo e autêntico possível. Mas o fato de existir a possibilidade de outros documentos não terem sido catalogados nas bases de dados averiguadas, por exemplo, impossibilita afirmar que o levantamento conseguiu reunir a totalidade de trabalhos existentes no período avaliado. De qualquer forma, o esforço para resgatar e reunir esses materiais foi grande, conseguindo então agrupar dois livros, cinco teses, vinte e uma dissertações e sessenta e quatro artigos. Neste sentido, a estrutura metodológica da revisão sistemática foi eficiente para estipular, ordenar e justificar os passos a serem seguidos.

Vale destacar uma importante referência consultada que ajudou muito a realização deste levantamento. O Núcleo de Pesquisa em Informação, Tecnologias e Práticas Sociais (INFOTEC), ligado ao Programa de Pós-Graduação em Comunicação e Informação da UFRGS, sob a coordenação da Prof ${ }^{\mathrm{a}}$. Dr ${ }^{\mathrm{a}}$. Ida Regina Stumpf. O núcleo tem o objetivo desenvolver estudos e pesquisas relacionados à geração, transferência e utilização da informação nos ambientes científico, tecnológico, empresarial e da sociedade em geral ${ }^{108}$. E contém tanto um catálogo de revistas acadêmicas nacionais em comunicação distribuídas por ordem alfabética, quanto uma lista de teses e dissertações em Comunicação no Brasil com seus respectivos resumos, do ano 1992 até 2008.

Apesar de não se ter conseguido coletar $100 \%$ dos trabalhos na íntegra, considerou-se eficaz a estratégia da leitura técnica aplicada, proposta por (DIAS; NAVES, 2007), e que utiliza de partes dos textos para encontrar elementos importantes na identificação do assunto do documento. Apenas três materiais ficaram desfalcados: a dissertação "Análise dos Padrões

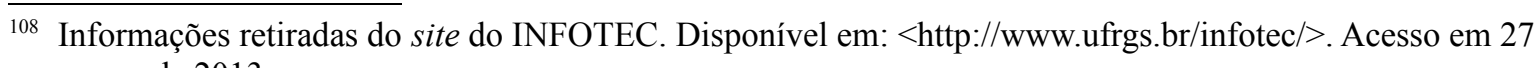
março de 2013. 
de Voz no Cinema: a comunicação oral humana em duas versões de The Nutty Professor" (CASTRO, 2001), a qual obteve-se apenas o título, o resumo e alguns parágrafos citados em outra pesquisa; da dissertação "O Surround e a Espacialidade Sonora no Cinema" (COSTA, 2004a), a qual obteve-se apenas o resumo, o sumário, a introdução e a bibliografia; e do artigo "O Sonho de Edison: o advento do som sincronizado" (CARRASCO, 2003), o qual obteve-se apenas o título e a informação de que ele foi retirado do capítulo homônimo da dissertação de mestrado do mesmo autor, CARRASCO (1993).

Como forma de investigar a variedade de assuntos e objetos de estudo encontrados, foram identificadas tendências relacionadas às temáticas dos trabalhos levantados. Algumas opções de organização chegaram a ser conjecturadas nos primórdios dessa dissertação, como por exemplo, separar os documentos de acordo com o gênero cinematográfico, ou com a nacionalidade da cinematografia estudada. Porém, estas categorias se tornaram muito restritivas e também nem todos os materiais possuem claramente o estudo voltado para um gênero ou região específica. Assim, analisando o conteúdo dos trabalhos, onze categorias foram estipuladas para agrupá-los. Foram elas: História; Tecnologia; Percepção Sonora; Processo de Criação; Elementos da Trilha Sonora; Estudo da Voz; Estudos do Ruído; Estudos do Silêncio; Teoria; Estética e Estilo; Estudos de Caso. Nenhuma foi considerada exclusiva.

A exposição acerca do perfil da pesquisa brasileira sobre o som no cinema foi fundamental para entender onde esta se concentra quantitativamente, quais os espaços contemporâneos que fomentam essa pesquisa e, então, contextualizar seu universo acadêmico de produção atual.

A partir então das informações assimiladas no segundo capítulo deste trabalho, consideram-se respondidas as questões centrais propostas ao formular o primeiro passo da revisão sistemática aqui realizada. Recordando: Quais e quantos são de fato os trabalhos brasileiros contemporâneos sobre o som no cinema? Quais os assuntos e objetos de estudo dentro da questão da trilha sonora cinematográfica presentes nos trabalhos? Quais as principais temáticas abordadas? Onde estão publicados esses materiais? Qual o perfil da pesquisa e dos autores dos trabalhos? Podendo ainda acrescentar mais duas quantitativamente averiguadas a nível de curiosidade: Quais e quantos desses materiais abordam questões relacionadas ao cinema brasileiro? E qual a quantidade de autores por gênero?

Inicialmente havia uma outra pergunta relacionada à forma metodológica com que as pesquisas levantadas foram realizadas, ou seja, a ideia era também discutir quais os possíveis métodos mais utilizados pelos pesquisadores que não somente a tradicional pesquisa bibliográfica, inerente a qualquer estudo acadêmico. Porém, esta ideia foi descartada pois 
notou-se uma deficiência na literatura brasileira sobre o som no cinema a respeito de sua estruturação metodológica. Poucos trabalhos levantados explicam claramente como foi desenvolvido o percurso ou os procedimentos adotados para chegar em seus objetivos finais de pesquisa. A maior parte não evidencia essa informação, ou apenas se apoia em uma fundamentação teórica de base referencial sem de fato se apegar a algum método tangível.

Diante das restrições necessárias para delimitar a realização da revisão sistemática aqui proposta, muitos trabalhos relacionados ao som cinematográfico ficaram de fora, como pode ser verificado, por exemplo, na lista presente no Anexo VII. Vale destacar que, se estendermos o campo brasileiro dos estudos do som no cinema ao universo do audiovisual, além de documentos relacionados às questões da trilha musical, há trabalhos dedicados à arte sonora, à audiodescrição, ao som em games, na internet, na televisão, etc. Em relação ao recorte temporal, também é possível notar a existência de materiais significativos publicados nos anos 2012 e 2013, que também ficaram de fora da pesquisa. A exemplo estão os livros por hora mencionados ao final do item "Evolução Quantitativa"; e a revista Filme Cultura no 58, que trinta e dois anos após sua edição 37 encadeada por Jean-Claude Bernardet em 1981, publica novamente uma edição dedicada exclusivamente à trilha sonora no cinema, intitulada “O Som Nosso de Cada Filme" (MATTOS, 2013). Ou ainda o surgimento de novos espaços de discussões como o Seminário Internacional "Ouvir o Documentário: música, vozes e ruídos", que teve sua primeira edição em 2012. Bem como o grupo de estudos do Programa de Pós-Graduação em Imagem e Som da UFSCar denominado "GESSOMA" criado em 2012, coordenado pela Prof ${ }^{a}$. Dr ${ }^{\text {a }}$. Suzana Reck Miranda, e que se dedica aos estudos sobre o uso do som e da música na linguagem audiovisual. Tudo isso demonstra a dimensão e a interdisciplinaridade que esse campo segue atingindo no país.

Desta forma, esta revisão sistemática não termina aqui. Para garantir sua continuidade, a ampliação de seus resultados, o acesso aos dados e uma maior notoriedade aos materiais levantados, foi elaborado juntamente com esse projeto de mestrado um portal online designado "Artesãos do Som" (acessível pelo endereço: www.artesaosdosom.org). Com mais de dois anos de atividade, o "Artesãos do Som" deixou de ser apenas um blog deste projeto para se tornar "uma das melhores fontes de pesquisa em língua portuguesa sobre o universo sonoro do cinema" segundo a conceituada e mais antiga revista de cinema em circulação no Brasil, a já mencionada Filme Cultura. Nas palavras do crítico Carlos Alberto Mattos, editor da Filme Cultura: 
Uma das melhores fontes de pesquisa em língua portuguesa sobre o universo sonoro do cinema é este blog criado pelo editor de som e pesquisador Bernardo Marquez. O endereço reúne reportagens, entrevistas, artigos, monografias, teses, dissertações, resenhas de livros e vídeos sobre o assunto. Uma atenção especial é dedicada aos bastidores da produção sonora, campo pouco conhecido até mesmo por muita gente profundamente familiarizada à criação de imagens. O conceito de "ouvido pensante" é não só uma das categorias do $b \log$, mas algo que perpassa todo o material ali reunido. A ideia é funcionar não só como um acervo de referências e atualidades sobre captação, edição, criação e reprodução do som cinematográfico, mas também como um portal para conteúdos dispersos na rede. O link "Grupos de som", por exemplo, remete a diversos fóruns nacionais e internacionais de discussão sobre o tema, de microfonistas a desenho de som. O blog tem um grupo de colaboradores, mas está aberto à contribuição de quem tiver textos, vídeos e curiosidades sobre a banda sonora dos filmes. (MATTOS, 2013: 95)

$\mathrm{Na}$ vontade de cooperar com o desenvolvimento de uma consciência sonora e uma maior valorização da área, seja na pesquisa, no ensino ou na prática profissional, esta dissertação complementa um projeto que se iniciou em meu trabalho de conclusão de curso em 2009, sobre O Universo Profissional das Etapas da Produção Sonora Cinematográfica, voltando-se agora ao universo dos estudos do som no cinema. Assim, espera-se que este trabalho siga adiante sendo de alguma forma útil para aqueles que se interessam pelo assunto. Há ainda um longo caminho a ser explorado. 


\section{REFERÊNCIAS}

\section{Bibliografia \\ INTRODUÇÃO}

ALTMAN, Rick (org). IRIS: A Journal of Theory on Image and Sound, n. 27. The State of Sound Studies/Le son au cinéma, état de la recherche. France/USA: Institute for Cinema and Culture - The University of Iowa, Spring 1999a.

, Rick. Introduction. In: IRIS: A Journal of Theory on Image and Sound, n. 27. The State of Sound Studies/Le son au cinéma, état de la recherche. France/USA: Institute for Cinema and Culture - The University of Iowa, Spring 1999b.

, Rick. Penser l'histoire du cinéma autrement: un modèle de crise. In: Vingtième Siècle. Revue d'histoire. No 46, avril-juin 1995. pp. 65-74.

, Rick. Silent Film Sound. New York: Columbia University Press, 2004.

, Rick (org.). Sound Theory/Sound Practice. New York: Routledge, 1992.

n. 60, 1980a.

, Rick (org.). Yale French Studies - Cinema/Sound. New Haven: Yale University Press, , Rick. Introduction. In: Yale French Studies - Cinema/Sound. New Haven: Yale University Press, n. 60, 1980b.

ALVES, Bernardo Marquez. O Universo Profissional das Etapas da Produção Sonora Cinematográfica. Monografia (Trabalho de Conclusão do Curso de Comunicação Social: Radialismo). FAAC, Unesp. Bauru, 2009.

BARONNET, Jean. Eloge de la phonie. Cahiers du Cinéma, n. 152, février 1964.

BECK, Jay; GAC, Franck Le. Sound Resources on the Internet. In: IRIS: A Journal of Theory on Image and Sound, n. 27. The State of Sound Studies/Le son au cinéma, état de la recherche. France/USA: Institute for Cinema and Culture - The University of Iowa, Spring 1999.

, Jay; GRAJEDA, Tony (Eds). Lowering the Boom: Critical Studies in Film Sound. Urbana: University of Illinois Press, 2008.

BERNARDET, Jean-Claude. O som no cinema brasileiro. In: Filme Cultura, Rio de Janeiro: Embrafilme, n. 37, 1981.

BIZARRO, Nicola. Pierre Schaeffer's contribution to audiovisual theory. Worlds of Audiovision: Università degli Studi di Pavia, 2011.

BOORMAN, John; LUDDY, Tom; THOMSON, David; DONOHUE, Walter (edit). Projections 4: Film-makers on Film-making. London: Faber and Faber, 1995. 
CARRASCO, Claudiney Rodrigues. Trilha Musical: música e articulação fílmica. Dissertação (Mestrado em Cinema). USP. São Paulo, 1993.

, Claudiney Rodrigues. Sygkhronos: a formação da poética musical do cinema. Tese (Doutorado em Música). UNICAMP. Campinas, 1999.

CAVALCANTI, Alberto. Filme e Realidade. São Paulo: Livraria Martins Fontes, 1953.

, Alberto. Sound in Films. In: WEIS, Elisabeth; BELTON, John (Org). Film sound: theory and practice. New York: Columbia University Press. 1985.

CHEVASSU, François (ed.). La Revue du Cinéma, n. 215. Le Son au Cinéma. Paris: UFOLEIS, mars 1968.

CHION, Michel. A Audiovisão: som e imagem no cinema. Lisboa: Edições Texto \& Grafia, 2011.

, Michel. L'Audio-Vision. Paris: Nathan, 1991.

, Michel. Le son au cinéma. Paris: Cahiers du Cinéma, Ed. de l'Etoile, 1985.

, Michel. La voix au cinéma. Paris: Cahiers du Cinéma, Ed. de l'Etoile, 1982.

, Michel. Problèmes et solutions pour développer l'étude du son, em Europe et dans le mond. In: IRIS: A Journal of Theory on Image and Sound, n. 27. The State of Sound Studies/Le son au cinéma, état de la recherche. France/USA: Institute for Cinema and Culture - The University of Iowa, Spring 1999.

CLAIR, Réne. The Art of Sound. In: WEIS, Elisabeth; BELTON, John (Org). Film sound: theory and practice. New York: Columbia University Press. 1985.

COHEN, John S. This Year of Sound. Theatre Arts Magazine: Theatre Arts Monthly. New York, 1929.

COSTA, Fernando Moraes da. O som no cinema brasileiro. Rio de Janeiro: 7Letras, 2008.

DELGADO, María Elena Gutiérrez. La creación sonora del audiovisual. Seleccíon bibliográfica. La Habana: Fundación del Nuevo Cine Latinoamericano, 2011.

DONALD, James; FRIEDBERG, Anne; MARCUS, Laura. Close Up, 1927-1933: Cinema and Modernism. Continuum International Publishing Group, 1998

EISENSTEIN, Sergei. A forma do filme. Rio de Janeiro: Jorge Zahar, 1990.

, Sergei; PUDOVKIN, V. I.; ALEXANDROV. A Statement. In: WEIS, Elisabeth; BELTON, John (Org). Film sound: theory and practice. New York: Columbia University Press. 1985.

FANO, Michel. Vers une dialectique du film sonore. Cahiers du Cinéma, n. 152, février 1964. 
FELICE, Fabricio. O Cinema Brasileiro em O Fan: o Chaplin-Club e sua relação com o pensamento industrial cinematográfico na década de 1920. Anais do $\mathbf{1}^{\circ}$ Congresso Mundial de Comunicação Ibero-Americana (CONFIBERCOM). São Paulo, 2011.

FORLENZA, Jeff; STONE, Terri (eds.). Sounds of Movies: interviews with the creators of feature sound tracks. Emeryville,CA: MixBooks, 1993.

GOMERY, Douglas. The Coming of Sound to the American Cinema: a history of the transformation of an industry. Ph.D. Dissertation. University of Wisconsin. Madison, 1975.

GORBMAN, Claudia. Bibliography on Sound in Film. In: ALTMAN, Rick (org.). Yale French Studies - Cinema/Sound. New Haven: Yale University Press, n. 60, 1980.

, Claudia. Teaching the Soundtrack. Quarterly Review of Film Studies (November 1976): 446-452.

HAYS, William H. See and Hear: A Brief History of Motion Pictures and the Development of Sound. New York: MPPDA, 1929.

HILMES, Michele. Is There a Field Called Sound Culture Studies? And Does It Matter?. In: American Quarterly, Vol. 57, No. 1 (March, 2005), p. 249-259.

IRIS: A Journal of Theory on Image and Sound, n. 27. The State of Sound Studies/Le son au cinéma, état de la recherche. France/USA: Institute for Cinema and Culture - The University of Iowa, Spring 1999.

KELLOGG, Edward W. Historyof Sound Motion Pictures. In: Journal (JSMPE). Society of Motion Picture Engineers. Parte I: Vol. 64, no 6 (June 1955): 291-302. Parte II: Vol. 64, n 7 (July1955): 356-374. Parte III: Vol. 64, no 8 (Aug. 1955): 422-437.

LoBRUTTO, Vicent. Sound-on-Film: interviews with the Creators of Film Sound. London: Praeger Publishers, 1994.

MANCHEL, Frank. Film Study: an analytical bibliography. New Jersey: Fairleigh Dickinson Univ Press, 1990. 1973.

Frank. Film Study: a resource guide. New Jersey: Fairleigh Dickinson Univ. Press,

MANZANO, Luiz Adelmo F.. A Relação Som-Imagem no Cinema: a experiência alemã de Fritz Lang. Dissertação (Mestrado em Comunicação). USP. São Paulo, 1999.

MARKS, Martin Miller. Music and the Silent Film: Contexts and Case Studies, 1895-1924. Oxford University Press, 1997

MATTOS, Carlos Alberto, O Som Nosso de Cada Filme. Revista Filme Cultura, n. 58. Rio de Janeiro: CTAv/SAV/MinC, 2013. 
MENDES, Eduardo Simões dos Santos. A trilha sonora nos curta-metragens de ficção realizados em São Paulo entre 1982 e 1992. Dissertação (Mestrado em Artes) ECA, USP. São Paulo, 1994.

Eduardo Simões dos Santos. Walter Murch: a revolução no pensamento sonoro cinematográfico. Tese (Doutorado em Artes). USP. São Paulo, 2000.

McLAREN, Norman. Notes on Animated Sound. Quarterly of Film, Radio and Television. Vol. 7, nº 3 (Spring1953): 223-229.

MILICEVIC, Mladen. Film Sound Beyond Reality: subjective sound in narrative cinema. Loyola Marymount University. Los Angeles, sem data. Disponível em: $<$ http://myweb.lmu.edu/mmilicevic/NEWpers/_PAPERS/beyond.pdf $>$. Acesso em 10 de jun. 2013.

MIRANDA, Suzana Reck. A Música no Cinema e a Música do Cinema de Krzysztof Kieslowski. Dissertação (Mestrado em Multimeios). UNICAMP. Campinas, 1998.

MURCH, Walter. Foreword. In: CHION, Michel. Audio-Vision: sound on screen. New York: Columbia University Press, 1994. 1,2000 .

Walter. Stretching Sound to Help the Mind See. New York Times, New York, October

NATZÉN, Christopher. The Coming of Sound Film in Sweden 1928-1932. US-AB, Stockholm, 2010.

PASQUARIELLO, Nicholas. Sounds of Movies: interviews with the creators of feature sound tracks. Port Bridge Books, 1996.

PENNINGTON, David R. L.. Som Direto. Dissertação (Mestrado em Comunicação). UNB. Brasília, 1993.

PINCH, Trevor; BIJSTERVELD, Karin. Sound Studies: new technologies and music. In: Social Studies of Science, Vol. 34, No. 5, Special Issue on Sound Studies: New Technologies and Music (Oct.,2004), p. 635-648.

PUDOVKIN, V. I. Asynchronism as a Principle of Sound Film. In: WEIS, Elisabeth; BELTON, John (Org). Film sound: theory and practice. New York: Columbia University Press. 1985

RAMOS, Guiomar. Espaço fílmico sonoro em Arthur Omar. Dissertação (Mestrado em Comunicação). USP. São Paulo, 1995.

SEXTON, Jamie. The Audio-Visual Rhythms of Modernity: Song Of Ceylon, Sound and Documentary Filmmaking. SCOPE, University of Wales, Aberystwyth-UK, 2004.

Disponível em: $\quad<$ http://www.scope.nottingham.ac.uk/article.php? issue $=$ may2004\&id=249\&section=article $>$. Acesso em: 17 de jul. 2012. 
SOARES, Luiz Cláudio Cajaiba. Versão brasileira: dublagem na tv como recurso difusor do cinema. Dissertação (Mestrado). UFBA. Salvador, 1997.

SPONABLE, E. I. Historical Development of Sound Films. In: Journal (JSMPE). Society of Motion Picture Engineers. Vol. 48, Apr. 1947: 275-303 e May. 1947: 407-422.

TAYLOR, Richard. The Eisenstein Reader. London: British Film Institute, 1998.

VANZ. Samile; BRAMBILLA, Sônia; RIBEIRO, Ananda; STUMPF, Ida. Mapeamento das teses e dissertações em comunicação no Brasil (1992-2002): tendências temáticas. Revista FAMECOS, n. 33, p. 53-60. Porto Alegre, 2007.

WEIS, Elisabeth; BELTON, John (Org). Film sound: theory and practice. New York: Columbia University Press. 1985a.

, Elisabeth; BELTON, John. Preface. In: Film sound: theory and practice. New York: Columbia University Press. 1985b.

WIERZBICKI, James Eugene. Film Music: a history. New York: Taylor \& Francis, 2009.

WRIGHT, Basil; BRAUN, Vivian B. Manifesto: Dialogue on Sound. In: WEIS, Elisabeth; BELTON, John (Org). Film sound: theory and practice. New York: Columbia University Press. 1985.

YEWDALL, David Lewis. The Practical Art of Motion Picture Sound. Boston: Focal Press, 1999.

\section{Bibliografia \\ Capítulo 1}

ALDERSON, P.; GREEN, S.; HIGGINS, JPT. (ed.). Cochrane Reviewers' Handbook 4.2.2 [updated March 2004]. In: The Cochrane Library, Issue 1, 2004. Chichester, UK: John Wiley \& Sons, Ltd. Disponível em: <http://www.cochrane.org/resources/handbook/hbook.htm>. Acesso em 10 de agosto de 2012.

CASTRO, Aldemar Araujo. Revisão Sistemática e meta-análise. Metodologia.org, 2001. Disponível em: <http://metodologia.org/wp-content/uploads/2010/08/meta1.PDF>. Acesso em: 25 jul. 2012.

COOPER, Harris M.; HEDGES, Larry V.. The Handbook of Research Synthesis. Vol. 236. New York: Russel Sage Foundation, 1994.

DIAS, Eduardo Wense; NAVES, Madalena Martins Lopes. Análise de Assunto: teoria e prática. Brasília: Thesaurus, 2007.

HEMINGWAY, Pippa. What is a sysetmatic review?. Hayward Medical Communications. 2009. 
JOHNSON, Blair T.; SCOTT-SHELDON, Lori A. J.; SNYDER, Leslie B.; NOAR, Seth M.; HUEDO-MEDINA, Tania. Comtemporary Approaches to Meta-Analysis in Communication Research. In: HAYES, A.F.; SLATER, M.D.; SNYDER, L.B. (ed.). The SAGE Sourcebook of Advanced Data Analysis Methods for Communication Research. Pag. 311-347. SAGE Publications, 2007.

POCINHO, Margarida. Lições de Revisão Sistemática e Metanálise. Portugal: Instituto Superior Miguel Torga, 2008. Disponível em:

$<\mathrm{http}: / /$ docentes.ismt.pt/ $\mathrm{m} \_$pocinho/Licoes_de_revisao_sistematica_e_metanalise.pdf $>$. Acesso em 25 jul. 2012.

ROTHER, Terezinha Edna. Editorial: Revisão Sistemática x Revisão Narrativa. São Paulo: Acta Paulista Enfermagem, 2007.

UNIVERSIDADE DE SÃO PAULO. Sistema Integrado de Bibliotecas. Vocabulário Controlado do SIBi/USP. São Paulo, 2006. Disponível em:

$<$ http://143.107.73.99/Vocab/Sibix652.dll/ARV?HIER=CH741.2.5.2.18.13>. Acesso em: 29 de jul. 2012.

VALENCIA, Maria Cristina Palhares. Mapeamento das Pesquisas de Mestrado e Doutorado em Comunicação no Brasil: tendências temáticas construídas nos anos de 1980, 1985, 1995 e 2000. Dissertação (Mestrado em Comunicação e Semiótica), PUC. São Paulo, 2005.

\section{Bibliografia}

Capítulo 2

ADES, Eduardo, BRAGANÇA, Gustavo, CARDOSO, Juliana e BOUILLET, Rodrigo (org). 2008. O Som no Cinema. Catálogo de mostra e curso realizados na Caixa Cultural. Tela Brasilis, Rio de Janeiro.

CAESAR, Rodolfo. O tímpano é uma tela?. In: VI Forum do Centro de Linguagem Musical, 2004, São Paulo: Centro de Linguagem Musical - ECA/USP, 2004, v.1, p. 17-25.

CARRASCO, Claudiney Rodrigues. Trilha Musical: música e articulação fílmica. Dissertação (Mestrado em Cinema). USP. São Paulo, 1993.

CASTANHEIRA, José C. S. O soundscape da modernidade: os Sound Studies e o som no cinema. In: XII Estudos de Cinema e Audiovisual Socine, Vol. 2, p. 325-338. São Paulo, 2011.

CHION, Michel. A Audiovisão: som e imagem no cinema. Lisboa: Edições Texto \& Grafia, 2011.

COSTA, Fernando Moraes da. Catálogo da Mostra E o Som se Fez. In: Mostra E o Som se Fez. CCBB, São Paulo, 2007.

, Fernando Moraes da. Som no Cinema, Silêncio nos Filmes: o inexplorado e o inaudito. Dissertação (Mestrado em Comunicação Social). UFF. Rio de Janeiro, 2003. 
CUNHA, Damyler. As dimensões reais e imaginárias do som nos filmes de Licrecia Martel. Dissertação (Mestrado em Ciências). USP. São Paulo, 2013.

DÖPPENSCHMITT, Elen. Políticas da Voz no Cinema em Memórias do Subdesenvolvimento. 1 ed. São Paulo: EDUC, 2012.

GORBMAN, Claudia. ANNOTATED BIBLIOGRAPHY. In: WEIS, Elisabeth e BELTON, John (Org). Film sound: theory and practice. New York: Columbia University Press. 1985.

, Claudia. Bibliography on Sound in Film. In: ALTMAN, Rick (org.). Yale French Studies - Cinema/Sound. New Haven: Yale University Press, n. 60, 1980.

MAGAlHÃES, Michelle Agnes. Futurismo e Música na trilha sonora de Dziga Vertov. Dissertação (Mestrado em Música). UNICAMP. Campinas, 2005.

MANZANO, Luiz Adelmo Fernandes. Som-imagem no cinema: a experiência alemã de Friz Lang. São Paulo: Perspectiva: FAPESP, 2003.

MASSAD, T.M.M. Estética, Estilo e Direito. Revista Núcleo de Pesquisa Interdisciplinar, São Miguel, 2006. Disponível em: < http://www.fmr.edu.br/npi/008.pdf>. Acesso em: 10 de agosto 2012.

McGILL, Amy Charlotte. The Contemporary Hollywood Film Soundtrack: Professional Practices and Sonic Styles Since the 1970s. Tese (Doutorado em Filosofia em Inglês). University of Exeter. Inglaterra, 2008.

MANZANO, Luiz Adelmo Fernandes. A evolução do som cinematográfico e M, o Vampiro de Düsseldorf. Catálogo da Mostra Sound Design: Projeto de Som. In: Mostra Sound Design: Projeto de Som, 2004, São Paulo.

MENDES, Eduardo Santos. Catálogo da Mostra Sound Design: Projeto de Som. In: Mostra Sound Design: Projeto de Som, 2004, São Paulo.

, Eduardo Santos. Walter Murch: a revolução da trilha sonora cinematográfica. Tese (Doutorado em Artes) ECA, USP. São Paulo, 2000.

PEREIRA, Luciana Almeira. Princípios da Articulação Sonora no Cinema. Dissertação (Mestrado em Artes). UFMG. Belo Horizonte, 1999.

PONTIFÍCIA UNIVERSIDADE CATÓLICA DE SÃO PAULO. Regulamento do Programa de Estudos Pós-Graduados em Comunicação e Semiótica. PUC, São Paulo, sem data. Disponível em: < http://www4.pucsp.br/cos/arquivos/regulamentoCos.pdf $>$. Acesso em $14 \mathrm{de}$ junho de 2013.

QUINTANA, Fabiana. Orfeu: do mito à realidade brasileira - uma análise da trilha sonora dos filmes "Orfeu negro" (1959) e "Orfeu" (1999) baseados na peça "Orfeu da Conceição" de Vinícius de Moraes. Dissetação (Mestrado em Multimeios) UNICAMP. Campinas, 2011.

SÁ, Simone Pereira de; COSTA, Fernando Morais da (org.). Som + Imagem. Rio de Janeiro: 7Letras, 2012. 
SIBILIA, Mauricio de B. e P.. Editorial. Ciberlegenda (UFF. Online), n.24, v. 01, 2011.

VASCONCELOS. André Luiz Olzon. A influência da trilha sonora sobre a percepção da obra cinematográfica: $A$ análise filmica de Bye bye Brasil, Pra frente Brasil e Central do Brasil. Dissertação (Mestrado em Música). UNICAMP. Campinas, 2008.

WEIS, Elisabeth. The Trail of the Snail: Recent Literature on Sound Design. In: IRIS: A Journal of Theory on Image and Sound, n. 27. The State of Sound Studies/Le son au cinéma, état de la recherche. France/USA: Institute for Cinema and Culture - The University of Iowa, Spring 1999.

\section{Bibliografia \\ CONCLUSÃO}

CARRASCO, Claudiney. O Sonho de Edison: o advento do som sincronizado. ArtCultura (UFU), v. 5, n. 6, p. 53-65, 2003.

CASTRO, Luciana. Análise dos Padrões de Voz no Cinema: a comunicação oral humana em duas versões de The Nutty Professor. Dissertação (Mestrado em Educação em Ciências e Saúde). UFRJ. Rio de Janeiro, 2001.

COSTA, Nélio José Batista. O surround e a espacialidade sonora no cinema. Dissertação (Mestrado em Artes). UFMG. Belo Horizonte, 2004a.

DIAS, Eduardo Wense; NAVES, Madalena Martins Lopes. Análise de Assunto: teoria e prática. Brasília: Thesaurus, 2007.

MATTOS, Carlos Alberto. O Som Nosso de Cada Filme. Revista Filme Cultura, n. 58. Rio de Janeiro: CTAv/SAV/MinC, 2013.

\section{WEBGRAFIA}

CARLSSON, Sven E. Film Sound Bibliography. In: FILMSOUND: Your Learning Space for Film Sound. Sem data. Disponível em: < http://www.filmsound.org/bibliography/littlist.htm>. Acesso em: 22 jun. 2012.

CASTRO, Aldemar A.. Revisão Sistemática e meta-análise. Metodologia.org, 2001. Disponível em: <http://www.metodologia.org/meta1.PDF>. Acesso em: 25 jul. 2012.

LAVOIE, Pierre. La Création Sonore: Bibliographie. Université de Montréal, sem data. Disponível em: <http://www.creationsonore.ca/creation-sonore.php?bibliographie\#Arts-duson>. Acesso em 22 jan. 2012.

MERA, Miguel. A Selected Bibliography of Sound and Music for Moving Pictures. Royal College of Music, London, sem data. Disponível em: <http://www.schoolofsound.co.uk/>. Acesso em 30 nov. 2012. 
WULFF, Hans J. Sound. Eine Arbeitsbibliographie. Christian-Albrechts-Universität Kiel, Institut für NDL und Medien, Leibnizstr, 2000. Disponível em: <http://www.unikiel.de/medien/bersound.html>. Acesso em 22 jan. 2012.

- Associação Nacional de Pesquisa e Pós-Graduação em Música (ANPPOM): $<$ http://www.anppom.com.br/>

- Associação Nacional dos Programas de Pós-Graduação em Comunicação (COMPÓS): $<$ http://www.compos.org.br/pagina.php?menu=1\&mmenu=>

- Banco de teses da CAPES: <http://www.capes.gov.br/servicos/banco-de-teses>

- Biblioteca Digital Brasileira de Teses e Dissertações (BDTD): <http://bdtd.ibict.br/>

- Biblioteca Digital de Teses e Dissertações da PUC-SP: <http://www.sapientia.pucsp.br/>

- Biblioteca Digital de Teses e Dissertações da UERJ: <http://www.bdtd.uerj.br/>

- Biblioteca Digital de Teses e Dissertações da UFF: <http://www.bdtd.ndc.uff.br/tde_busca/>

- Biblioteca Digital de Teses e Dissertações da UFMG:

$<$ http://www.bibliotecadigital.ufmg.br/>

- Biblioteca Digital de Teses e Dissertações da UFPR:

$<$ http://www.portal.ufpr.br/teses_acervo.html $>$

- Biblioteca Digital de Teses e Dissertações da UFRJ: <http://fenix2.ufrj.br:8991/F?func=findb-0\&local_base=tdufrj>

- Biblioteca Digital de Teses e Dissertações da UFSCar:

$<$ http://200.136.241.56/htdocs/tedeSimplificado/tde_busca/index.php>

- Biblioteca Digital de Teses e Dissertações da UNICAMP:

$<$ http://www.bibliotecadigital.unicamp.br/document/list.php?tid=7>

- Biblioteca Digital de Teses e Dissertações da USP: <http://www.teses.usp.br>

- Biblioteca online de ciências da comunicação (BOCC): <http://www.bocc.ubi.pt/>

- Catálogo da Biblioteca Paulo Emilio Salles Gomes (Cinemateca Brasileira): $<$ http://www.cinemateca.gov.br/cgi-bin/wxis.exe/iah/?

IsisScript $=\mathrm{iah} / \mathrm{iah} . \mathrm{xis} \& \mathrm{base}=\mathrm{ACERVO \& lang}=\mathrm{p}>$

- Directory of Open Acces Journals (DOAJ): <http://www.doaj.org/>

- JSTOR: <http://www.jstor.org/>

- Mnemocine: <http://www.mnemocine.com.br/> 
- Núcleo de Pesquisa em Informação, Tecnologias e Práticas Sociais (INFOTEC-UFRGS):

$<$ http://www.ufrgs.br/infotec/>

- Plataforma Lattes: <http://lattes.cnpq.br/>

- Portal de Produção Científica em Comunicação (UNIVERCIENCIA):

$<$ http://www.univerciencia.org/>

- Portal de Revistas de Acesso Aberto em Ciências da Comunicação:

$<$ http://www.revistas.univerciencia.org/>

- Relação dos programas e cursos de pós-graduação recomendados e reconhecidos pela

CAPES: <http://www.capes.gov.br/cursos-recomendados>

- Sociedade Brasileira de Estudos de Cinema e Audiovisual (SOCINE):

$<$ http://www.socine.org.br/>

- Sociedade Brasileira de Estudos Interdisciplinares da Comunicação (INTERCOM):

$<$ http://www.intercom.org.br/>

- Sociedade de Engenharia de Áudio (AES-Brasil):

$<\mathrm{http}: / /$ aesbrasil.org/site/>

\section{Bibliografia de Apoio}

ASSOCIAÇÃO BRASILEIRA DE NORMAS TÉCNICAS (ABNT). NBR 6023: informação e documentação - Referências - Elaboração. Rio de Janeiro: ABNT, 2002.

ABNT, 2003.

NBR 6028: informação e documentação - Resumo - Apresentação. Rio de Janeiro:

ALVES, Bernardo Marquez. Sound Studies no Cinema: panorama da produção bibliográfica até a década de 1960. In: Anais da III Jornada Discente do PPGMPA da ECA/USP. São Paulo, 2012.

BECK, Jay; GRAJEDA, Tony (Eds). Lowering the Boom: Critical Studies in Film Sound. Urbana: University of Illinois Press, 2008.

DIAS, Eduardo Wense; NAVES, Madalena Martins Lopes. Análise de Assunto: teoria e prática. Brasília: Thesaurus, 2007.

GLASS, Gene. Meta-Analyse at 25. College of Education: Arizona State University, 2000. Disponível em: <http://www.gvglass.info/papers/meta25.html $>$. Acesso em 20 de jul. 2012.

, Gene. Primary, Secondary and Meta-análise of Research. Laboratory of Education Research: University of Colorado, 1976. Disponível em:

$<$ http://stat.smmu.edu.cn/uppic/file/pdf/primary.pdf $>$. Acesso em 22 de jul. 2012. 
HEMINGWAY, Pippa. What is a sysetmatic review?. Hayward Medical Communications. 2009.

KASSABIAN, Anahid; GARDINER, Ian. Music, Sound, and the Movie Image. Project MUSE, v.2, i.2. Liverpool: Liverpool University Press, 2008.

MACIAS-CHAPULA, Cesar A.. O papel da informetria e da cienciometria e sua perspectiva nacional e internacional. Revista Ciências da Informação [online]. IBICT, Vol.27, n.2, p. 134-140. Brasília, 1998. Disponível em: <http://www.scielo.br/pdf/ci/v27n2/macias.pdf>. Acesso em 30 nov. 2012.

MANCHEL, Frank. Film Study: an analytical bibliography. New Jersey: Fairleigh Dickinson Univ Press, 1990.

, Frank. Film Study: a resource guide. New Jersey: Fairleigh Dickinson University Press, 1973.

MARCONI, Marina de Andrade; LAKATOS, Eva Maria. Fundamentos de Metodologia Científica. $5^{\text {a }}$ edição. São Paulo: Atlas, 2003.

, Marina de Andrade; , Eva Maria. Técnicas de Pesquisa: planejamento e execução de pesquisas; amostragens e técnicas de pesquisa; elaboração, análise e interpretação de dados. 3 ed. São Paulo: Atlas, 1996.

NASTA, Dominique; HUVELlE, Didier (ed.). Le Son en Perspective: nouvelles recherches. Repenser le Cinéma, v. 01. Bruxelles: Peter Lang, 2004.

STERN, Jonathan (ed.). The Sound Studies Reader. Abingdon: Routledge, 2012.

UNIVERSIDADE DE SÃO PAULO. Sistema Integrado de Bibliotecas da USP. Diretrizes para apresentação de dissertações e teses da USP: documento eletrônico e impresso Parte I (ABNT) / Sistema Integrado de Bibliotecas da USP; Vânia Martins Bueno de Oliveira Funaro, coordenadora. [et al.]. 2. ed. rev. ampl. São Paulo: Sistema Integrado de Bibliotecas da USP, 2009.

VANTI, Nadia Aurora Peres. Da bibliometria à webometria: uma exploração conceitual dos mecanismos utilizados para medir o registro da informação e a difusão do conhecimento. Ciência da Informação, Brasília, v. 31, n. 2, p. 152-162, maio/ago. 2002. 


\section{ANEXO I}

Lista bibliográfica completa distribuída por ano.

\section{$\underline{2001}$}

\section{Dissertações:}

CASTRO, Luciana. Análise dos Padrões de Voz no Cinema: a comunicação oral humana em duas versões de The Nutty Professor. Dissertação (Mestrado em Educação em Ciências e Saúde). UFRJ. Rio de Janeiro, 2001.

$\underline{2002}$

$\underline{2003}$

Livro:

MANZANO, Luiz Adelmo Fernandes. Som-imagem no cinema: a experiência alemã de Fritz Lang. São Paulo: Perspectiva: FAPESP, 2003.

\section{Dissertações:}

COSTA, Fernando Morais da. Som no cinema, silêncio nos filmes: o inexplorado e o inaudito. Dissertação (Mestrado em Comunicação). UFF. Rio de Janeiro, 2003a.

\section{Artigos:}

CARRASCO, Claudiney. O Sonho de Edison: o advento do som sincronizado. ArtCultura (UFU), v. 5, n. 6, p. 53-65. Uberlândia, 2003.

COSTA, Fernando Morais da. A inserção do som no cinema: percalços na passagem de um meio visual para audiovisual. In: Anais do I Encontro Nacional da Rede Alfredo de Carvalho. Rio de Janeiro, 2003f.

, Fernando Morais da. Escutar tanto quanto se vê (como um filme iraniano, sobre uma criança cega, pode ensinar a ouvir?). In: Anais do XXVI Congresso brasileiro de ciências da comunicação - INTERCOM. Belo Horizonte, 2003b.

, Fernando Morais da. Ruídos e silêncio: proposta para uma estética do som no cinema. In: FABRIS, Mariarosaria et al. (Org.). Estudos Socine de cinema, Ano III. Porto Alegre: Sulina, 2003d, v. , p. 313-319. 
COSTA, Fernando Morais da. Que papel é delegado ao som, em um meio audiovisual? A imagem preponderante, e a inserção do som no cinema. Ecos Revista, Pelotas - RS, v. 7, n. 1, p. 71-91, 2003e.

, Fernando Morais da. São Bernardo: mosaico de vozes (mostruário dos diversos usos da voz no cinema). In: CATANI, Afrânio Mendes et al. (Org.). Estudos Socine de cinema, Ano IV. São Paulo: Panorama, 2003c, v. , p. 345-350.

DOBAL, Suzana M. Robert Bresson: o cinema num atormentado silêncio. In: FABRIS, Mariarosaria et al. (Org.). Estudos Socine de cinema, Ano III. Porto Alegre: Sulina, 2003, v. , p. 275-281.

$\underline{2004}$

\section{Dissertações:}

COSTA, Nélio José Batista. O surround e a espacialidade sonora no cinema. Dissertação (Mestrado em Artes). UFMG. Belo Horizonte, 2004a.

\section{Artigos:}

BELLEBONI, Luciene. A difícil relação entre imagem e som no audiovisual contemporânea. In: Anais do II Encontro Nacional da Rede Alfredo de Carvalho, UFSC-Florianópolis, 2004.

COSTA, Fernando Morais da. Se pouco se diz sobre o som, quem fala sobre o silêncio nos filmes?. Gragoatá - Revista do Programa de Pós-Graduação em Letras UFF, Niterói, v. 16, p. 105-116, 2004b.

MENDES, Eduardo Santos. Pensando a Relação Imagem-Som. TEOREMA - Crítica de Cinema, Porto Alegre, v. 5, p. 51-55, 2004.

\section{$\underline{2005}$}

Teses:

MANZANO, Luiz Adelmo Fernandes. O som no cinema: da edição de som ao sound design - evolução tecnológica e produção brasileira. Tese (Doutorado em Ciências da Comunicação). USP. São Paulo, 2005.

\section{Dissertações:}

DÖPPENSCHMITT, Elen Cristina Souza. Um Estudo da Performance da Oralidade no Cinema: registros da voz na linguagem documental. Dissertação (Mestrado em Comunicação e Semiótica). PUC. São Paulo, 2005. 
CAPELLER, Ivan. Introdução à arqueologia da escuta ou o nascimento do cinema sonoro a partir do espírito da ópera. Dissertação (Mestrado em Comunicação). UFF. Rio de Janeiro, 2005.

\section{Artigos:}

MENDES, Eduardo Santos; PINTO, Ivonete. Lucrecia Martel e o benefício da incerteza. TEOREMA - Crítica de Cinema, Porto Alegre, v. 8, 2005.

\section{$\underline{2006}$}

Teses:

COSTA, Fernando Morais da. O som no cinema brasileiro: revisão de uma importância indeferida. Tese (Doutorado em Comunicação Social). UFF. Rio de Janeiro, 2006.

\section{Dissertações:}

AMARAL, Vitória Rocha Prado. A voz na mise en scène: o filme Cidade de Deus sob a escuta fonoaudiológica. Dissertação (Mestrado em Fonoaudiologia). PUC-SP. São Paulo, 2006.

FLORES, Virginia Osorio. O Cinema, uma arte sonora. Dissertação (Mestrado em Música) UFRJ. Rio de Janeiro, 2006.

\section{Artigos:}

COSTA, Fernando Morais da. Primeiras tentativas de sonorização no cinema brasileiro (os cinematógrafos falantes 1902-1908). (versão integral). Mnemocine, 2006. Disponível em: $<$ http://www.mnemocine.com.br/index.php/cinema-categoria/25-historia-no-cinema-historiado-cinema/121-primeiras-tentativas-de-sonorizacao-no-cinema-brasileiro-os-cinematografosfalantes-1902-1908>. Acesso em 07 de jul. 2012.

MENDES, Eduardo Santos. Walter Murch: a revolução da trilha sonora cinematográfica (187/224). In: Significação no 26. São Paulo: Annablume, 2006.

\section{$\underline{2007}$}

\section{Dissertações:}

ALVAREZ, Mariano Gabriel. A Estereofonia Digital: uma abordagem sobre a técnica, o padrão e a linguagem sonora cinematográfica norte-americana no período de 1991 a 2001. Dissertação (Mestrado em Ciências da Comunicação). USP. São Paulo, 2007. 
BRÄUTIGAM, Alexandre Baliú. Sonologia e Cinema: elementos para análise áudio-visual. Dissertação (Mestrado em Música). UFRJ. Rio de Janeiro, 2007.

\section{Artigos:}

DÖPPENSCHMITT, Elen. A voz nas Memórias do Subdesenvolvimento: de Edmundo Desnoes a Tomás Gutiérrez Alea. In: Anais do XI Encontro Regional da Associação Brasileira de Literatura Comparada (ABRALIC). São Paulo, 2007a.

, Elen . Voz e Canto Popular do Negro no Cinema - poética cinematográfica no documentário Adão ou Somos Todos Filhos da Terra de Walter Salles e Daniela Thomas. UNIMONTES Científica, v. 8, p. 41-50, 2007b.

FLORES, Virginia Osorio. A Escuta Fílmica: uma atitude estética. XVII Congresso da Associação Nacional de Pesquisa e Pós-graduação em Música (ANPPOM). São Paulo, 2007.

LINS, Consuelo. O ensaio no documentário e a questão da narração em off. In: XVI Encontro Nacional da Compós, 2007, Curitiba. Anais do XVI Encontro Nacional da Compós. Curitiba: Tuiuti/Compós, 2007.

MENDES, Eduardo Santos; CARRASCO, Claudiney. A relação imagem/som nos filmes de Kubrick. Revista Cult, São Paulo, p. 55 - 59, 01 out. 2007.

MIRANDA, Suzana Reck. Vozes Polifônicas e Escutas Musicais: a articulação da banda sonora em François Girard. In: Machado, Jr. R.; Soares, R. De L.; Araújo, L. C. de. (Org.). Estudos de Cinema - Socine VIII. São Paulo: Anna Blume, 2007, v.1, p. 41-48.

SILVA, Márcia Regina Carvalho da. A Trilha Sonora do Cinema: proposta para um "ouvir" analítico. Caligrama: Revista de Estudos e Pesquisa em Linguagem e Mídia. São Paulo, vol. 03, no 01, 2007.

\section{$\underline{2008}$}

\section{Livros:}

COSTA, Fernando Morais da. O som no cinema brasileiro. Rio de Janeiro: 7Letras: FAPERJ, 2008.

\section{Dissertações:}

ASPAHAN, Pedro Cardoso. Entre a escuta e a visão: o lugar do espectador na obra de Robert Bresson. Dissertação (Mestrado em Comunicação Social). UFMG. Belo Horizonte, 2008 . 
GUIMARÃES, Clotilde Borges. A introdução do som direto no cinema documentário brasileiro na década de 1960. Dissertação (Mestrado em Ciências da Comunicação). USP. São Paulo, 2008.

MARCOLINO, Márcio Cardoso. O Compositor Stanley Kubrick: análise do som do filme De olhos bem fechados de Stanley Kubrick através da teoria sonora de Michel Chion. Dissertação (Mestrado em Artes). UFMG. Belo Horizonte, 2008.

\section{Artigos:}

BOZICANIN, José Eduardo. As idéias da trilha sonora do filme Akira. RUA - Revista Universitária do Audiovisual, v. 4, p. 12, 2008. Disponível em: $<$ http://www.ufscar.br/rua/site/?p=163>. Acesso em 30 jul. 2011.

CASTANHEIRA, José Cláudio Siqueira. A Paisagem Sonora Eletrônica: a reconstrução do mundo sonoro contemporâneo no cinema. Contemporânea: revista de Comunicação e Cultura. Rio de Janeiro, vol. 06, 2008 a.

, José Cláudio Siqueira. Electronic Tonalities: o espaço eletrônico e a impressão de realidade na ficção científica. Contemporânea: revista de Comunicação e Cultura. Rio de Janeiro, vol. 11, 2008b.

DÖPPENSCHMITT, Elen. Por uma Política da Voz: Tomás Gutiérrez Alea e as Memórias do Subdesenvolvimento. Devires (UFMG), v. 5, p. 184-203, 2008.

GATTI, Andre Piero; MENDES, Eduardo Santos. A nova sonoridade do cinema em São Paulo. In: André Piero Gatti. (Org.). Coleção Cadernos de Pesquisa: O Novo Cinema Paulista. 1 ed. São Paulo: Centro Cultural São Paulo, 2008, v. 05, p. 43-64.

HAUSSEN, Luciana. Som, Câmera, Ação: a relevância do som na história do cinema. Sessões do Imaginário (Impresso), v. 20, p. 17-22. Porto Alegre, 2008.

LEME, Gerson Rios . Escutando o Cinema. RUA - Revista Univesitária do Audiovisual, v. 02, p. 145, 2008. Disponível em: <http://www.ufscar.br/rua/site/?p=145>. Acesso em 30 jul. 2011.

PEDREIRAS, Aline Riera. O som surround e suas formas de uso. Revista Sonora, vol. 1 (1), UNICAMP, 2008.

SILVA, Márcia Regina Carvalho da. De olhos e ouvidos bem abertos: uma classificação dos sons no cinema. Revista NAU - Revista de Comunicação Audiovisual da Intercom, São Paulo, v.1, n.2, p.199-216, ago/dez 2008. 


\section{Dissertações:}

OPOLSKI, Débora Regina. Análise do design sonoro no longa-metragem Ensaio Sobre a Cegueira. Dissertação (Mestrado em Música). UFPR. Curitiba, 2009a.

BARBOSA, Ana Luiza Pereira. A relação som-imagem nos filmes de animação norteamericanos no final da década de 1920: do silencioso ao sonoro. Dissertação (Mestrado em Ciências da Comunicação). USP. São Paulo, 2009.

CARVAlHO, Andreson Silva de. A Percepção Sonora no Cinema: ver com os ouvidos, ouvir com outros sentidos. Dissertação (Mestrado em Comunicação). UFF. Rio de Janeiro, 2009 .

\section{Artigos:}

BARRENHA, Natalia C.; PASSOS, Antônio Fernando da Conceição. À beira da piscina, à beira do quadro: A utilização do som off e a construção de tensão na obra de Lucrecia Martel. XXXII Congresso Brasileiro de Ciências da Comunicação (INTERCOM). Curitiba, 4 a 7 de setembro de 2009.

CASTANHEIRA, José Cláudio Siqueira. Pré-escutas: modelos de audibilidades dos primeiros cinemas. Entre.Meios, v. 6, 2009a.

, José Cláudio Siqueira. A Presença do Som: proposta para uma investigação material da experiência sonora no cinema. Contemporânea: revista de Comunicação e Cultura. Rio de Janeiro, vol. 07, $\mathrm{n}^{\circ}$ 06, 2009b.

OPOLSKI, Débora R. A paisagem sonora e a ambientação do desenho de som: Os Sons ambiente como localizadores espaciais e temporais no filme Ensaio Sobre a Cegueira. In: MusiMid, 2009, São Paulo. Anais do $5^{\circ}$ Encontro de Música e Mídia: Estéticas do Som, 2009b. p. 1-18.

PEREIRA, Kira Santos. Candinho: a construção do espaço narrativo através da relação imagem-som. RUA - Revista Universitária Audiovisual. São Carlos, 2009a. Disponível em: $<$ http://www.ufscar.br/rua/site/?p=1619>. Acesso em 30 jul. 2011.

, Kira Santos. Se Podes Ouvir, Escuta: relações audiovisuais do filme Ensaio Sobre a Cegueira e considerações sobre seu processo criativo. RUA - Revista Universitária do Audiovisual, p. 1-2, 2009b. Disponível em: $<$ http://www.rua.ufscar.br/site/?p=1680 $>$. Acesso em 30 jul. 2011.

QUINTANA, Fabiana. Orfeu: do mito a realidade brasileira. A importância da trilha sonora na estratégia narrativa de Cacá Diegues e sua relação com o contexto sociocultural de uma época. In: $5^{\circ}$ Encontro de Música e Mídia (MusiMid). Santos: Realejo Livros e Edições, 2009. 
TORRES, Alfredo Werney Lima. A Sinfonia dos Pássaros. RUA - Revista Universitária do Audiovisual. São Carlos, 2009. Disponível em: <http://www.ufscar.br/rua/site/? $\mathrm{p}=2194 \#$ ftn1>. Acesso em 30 jul. 2011.

\section{$\underline{2010}$}

Tese:

DÖPPENSCHMITT, Elen Cristina Souza Koch Vaz. Por uma Política da Voz no Cinema: estratégias para emancipação do espectador em Memórias do Subdesenvolvimento de Tomás Gutiérrez. Tese (Doutorado em Comunicação e Semiótica). PUC. São Paulo, 2010.

WERNECK, Daniel Leal. Movimentos Invisíveis: história da estética do som do cinema de animação. Tese (Doutorado em Artes). UFMG. Belo Horizonte, 2010.

\section{Dissertações:}

CASTANHEIRA, José Cláudio Siqueira. A Paisagem Sonora Eletrônica: a construção de novas audibilidades no cinema. Dissertação (Mestrado em Comunicação Social). UERJ. Rio de Janeiro, 2010a.

PEREIRA, Kira Santos. Se Podes Ouvir, Escuta: a gênese audiovisual de Ensaio Sobre a Cegueira. Dissertação (Mestrado em Ciências da Comunicação). USP. São Paulo, 2010.

SOUZA, Priscila Haydée. Expressividade oral no cinema: diálogos com a fonoaudiologia. Dissertação (Mestrado em Fonoaudiologia). PUC. São Paulo, 2010.

\section{Artigos:}

AMARAL, Vitoria Rocha Prado; FERREIRA, Léslie Piccolotto; SOUZA, Priscila Haydée. A Fonoaudiologia e o ator de cinema: relatos de profissionais do meio cinematográfico. Distúrbios da Comunicação, v. 22, p. 133-147, 2010a.

, Vitoria Rocha Prado; FERREIRA, Léslie Piccolotto; MARTZ, Maria Laura Wey; SOUZA, Priscila Haydée. Representações de Voz e Fala no Cinema. Galáxia, v. 10, p. 151$164,2010 \mathrm{~b}$.

CARREIRO, Rodrigo. O rádio e os silêncios: articulações sobre o uso do som em Cinema, aspirinas e urubus. XI Estudos de Cinema e Audiovisual (SOCINE). São Paulo, vol. 11, 2010a.

, Rodrigo. Relações entre imagens e sons no filme Cinema, Aspirinas e Urubus. Revista da Associação Nacional dos Programas de Pós-Graduação em Comunicação Ecompós, Brasília, v.13, $\mathrm{n}^{\circ}$ 1, $2010 \mathrm{~b}$. 
CASTANHEIRA, José Cláudio Siqueira. O som eletrônico no cinema: uma abordagem fenomenológica. Contemporânea: revista de Comunicação e Cultura. Ed 15: Rio de Janeiro, vol. $8, \mathrm{n} 2,2010 \mathrm{~b}$.

COSTA, Fernando Morais da. Pode o cinema contemporâneo representar o ambiente sonoro em que vivemos? Logos: Comunicação \& Universidade. Rio de Janeiro, vol. 17, $\mathrm{n}^{\circ} 32$, 2010 b.

, Fernando Morais da. Som e ritmo interno no plano-sequência. XI Estudos de Cinema e Audiovisual (SOCINE). São Paulo, vol. 11, 2010a.

QUINTANA, Fabiana. A Trilha sonora de um filme imaginário: Uma análise do filme BLUE (1993) de Derek Jarman. In: $6^{0}$ Encontro de Música e Mídia (MusiMid). São Paulo : Letra e Voz, 2010.

Tese:

SOUZA, João B. G. de. Procedimentos de trabalho na captação de som direto nos longasmetragens brasileiros Contra todos e Antônia: a técnica e o espaço criativo. Tese (Doutorado em Ciências da Comunicação) - Escola de Comunicações e Artes, USP, São Paulo, 2011.

\section{Dissertações:}

BARRENHA, Natalia C. A experiência do cinema de Lucrecia Martel: resíduos do tempo e sons à beira da piscina. Dissertação (Mestrado em Multimeios). UNICAMP, Campinas, 2011.

ESPOSITO, Mauricio de Caro. Criando Mundo com Sons: Pós-produção de som e sound design no cinema. Dissertação (Mestrado em Comunicação). Universidade Anhembi Morumbi. São Paulo, 2011.

PESSOA, Frederico Augusto V. de A.. O Lugar Fora do Lugar: topografias sonoras do cinema documentário. Dissertação (Mestrado em Artes). UFMG, Belo Horizonte, 2011.

\section{Artigos:}

ALVIM, Luiza B.A.M.. Paisagens sonoras de Robert Bresson. Ciberlegenda (UFF. Online), n.24, v. 01, p. $62-72,2011$

ALMEIDA, Natasha Hernandez. O artista silencioso: um estudo da construção sonora no filme do Cineclube Universitário de Campinas. CoMtempo (Revista Eletrônica do Programa de Pós-Graduação em Comunicação da Faculdade Cásper Líbero), vol. 2, n2, ano 3. São Paulo, dez. 2011. 
ALVES, Bernardo Marquez. Produção Sonora no Cinema Contemporâneo: um olhar sobre desafios do som no cinema brasileiro e o processo de finalização de som do filme Tropa de Elite 2. Revista Cinema Caipira, n. 31. Rio Claro, set. 2011.

CALEIRO, Mauricio. A narrativa fonocinematográfica em $O$ Silêncio: audição subjetiva e cronotopias do espaço fílmico. Ciberlegenda (UFF. Online), n.24, v. 1, p. 138-148, 2011.

CAPELLER, Ivan. Introdução à Arqueologia da Escuta: do som e da voz como objetos de enunciação. Ciberlegenda (UFF. Online), n.24, v. 2, p. 7-15, 2011.

CARREIRO, Rodrigo. Os sons da continuidade intensificada: o caso de Sergio Leone. In: Laura Cánepa; Adalberto Müller; Gustavo Souza; Marcel Vieira. (Org.). XII Estudos de Cinema e Audiovisual (SOCINE). 1ed.São Paulo: Socine, 2011a, v. 2, p. 354-369.

, Rodrigo. Sobre o som no cinema de horror: padrões recorrentes de estilo. Ciberlegenda (UFF. Online), n.24, v.1, p. 29-42, 2011 b.

CASTANHEIRA, José Cláudio Siqueira. O soundscape da modernidade: os Sound Studies e o som no cinema. In: Laura Cánepa; Adalberto Müller; Gustavo Souza; Marcel Vieira. (Org.). XII Estudos de Cinema e Audiovisual (SOCINE). São Paulo: Socine, 2011a, v. 2, p. 325338.

, José Cláudio Siqueira. O Som Expandido: os novos espaços do som no cinema. Revista de Estudos da Comunicação, v. 12, p. 265-273, 2011 b.

COSTA, Fernando Morais da. Pode-se dizer que há algo como um hiper-realismo sonoro no cinema argentino?. Ciberlegenda (UFF. Online), n.24, v. 1, p. 84-90, $2011 \mathrm{a}$. $2011 b$.

, Fernando Morais da. Como soa hoje experimental?. Filme Cultura, v. 54, p. 49-54,

, Fernando Morais da. Os caminhos dos usos dos silêncios (ou a lembrança que não passa de John Cage). Ciberlegenda (UFF. Online), Niterói, 24 jul. 2011c. Disponível em: $<$ http://www.proppi.uff.br/ciberlegenda/os-caminhos-dos-usos-dos-sil\%C3\%AAncios>. Acesso em 30 jul. 2011.

CUNHA, Damyler Ferreira. A Submersão nas Imagens Sonoras: o som e suas dimensões reais e imaginárias. Revista Rumores. Ed. 9, vol 1, São Paulo, janeiro-junho de 2011.

FREIRE, Rafael de Luna. Versão brasileira Contribuições para uma história da dublagem cinematográfica no Brasil nas décadas de 1930 e 1940. Ciberlegenda (UFF. Online), n.24, v. 1, p. 7-18, 2011.

LEME, Gerson Rios. Pensando a trilha sonora para audiovisual. ORSON - Revista dos Cursos de Cinema do Cearte UFPEL, v. 1, p. 89-95, 2011

PIPANO, Isaac. Além do que se vê - o som e as paisagens sonoras no documentário Dong, de Jia Zhang-ke. Ciberlegenda (UFF. Online), n.24, v. 1, p. 73 / 07-83, 2011. 
RODRIGUES, Rodrigo Fonseca e. Sonoridades do cinema: Tarkovsky e a heterocronia da escuta. Mediação (Belo Horizonte), v. 13, p. 113-122, 2011.

VEDANA, Viviane. Diálogos sobre a imagem visual e a imagem sonora: a experiência de escritura do sonoro nos documentários etnográficos. Ciberlegenda (UFF. Online), n.24, v. 1, p. 29-42, 2011.

VENANCIO, Rafael D. O.. Efeitos sonoros enquanto fala audiovisual: Análise de Gerald McBoing-Boing à luz do $\$ 528$ das Investigações Filosóficas. Ciberlegenda (UFF. Online), n.24, v. 1, p. 126-137, 2011. 


\section{ANEXO II}

Lista bibliográfica completa distribuída por tendência temática.

\section{HISTORIA}

\section{Livros}

COSTA, Fernando Morais da. O som no cinema brasileiro. Rio de Janeiro: 7Letras: FAPERJ, 2008.

Teses:

COSTA, Fernando Morais da. O som no cinema brasileiro: revisão de uma importância indeferida. Tese (Doutorado em Comunicação Social). UFF. Rio de Janeiro, 2006a.

MANZANO, Luiz Adelmo Fernandes. O som no cinema: da edição de som ao sound design - evolução tecnológica e produção brasileira. Tese (Doutorado em Comunicação e Estética do Audiovisual). USP. São Paulo, 2005.

WERNECK, Daniel Leal. Movimentos Invisíveis: história da estética do som do cinema de animação. Tese (Doutorado em Artes). UFMG. Belo Horizonte, 2010.

\section{Dissertações:}

BARBOSA, Ana Luiza Pereira. A relação som-imagem nos filmes de animação norteamericanos no final da década de 1920: do silencioso ao sonoro. Dissertação (Mestrado em Comunicação). USP. São Paulo, 2009.

CAPELLER, Ivan. Introdução à arqueologia da escuta ou o nascimento do cinema sonoro a partir do espírito da ópera. Dissertação (Mestrado em Comunicação). UFF. Rio de Janeiro, 2005.

GUIMARÃES, Clotilde Borges. A introdução do som direto no cinema documentário brasileiro na década de 1960. Dissertação (Mestrado em Ciências da Comunicação). USP. São Paulo, 2008.

\section{Artigos:}

BELLEBONI, Luciene. A difícil relação entre imagem e som no audiovisual contemporânea. In: Anais do II Encontro Nacional da Rede Alfredo de Carvalho, UFSC-Florianópolis, 2004.

CAPELLER, Ivan. Introdução à Arqueologia da Escuta: do som e da voz como objetos de enunciação. Ciberlegenda (UFF. Online), n.24, v. 2, p. 7-15, 2011. 
CARRASCO, Claudiney. O Sonho de Edison: o advento do som sincronizado. ArtCultura (UFU), v. 5, n. 6, p. 53-65. Uberlândia, 2003.

COSTA, Fernando Morais da. A inserção do som no cinema: percalços na passagem de um meio visual para audiovisual. In: Anais do I Encontro Nacional da Rede Alfredo de Carvalho. Rio de Janeiro, $2003 \mathrm{f}$.

Fernando Morais da. Primeiras tentativas de sonorização no cinema brasileiro (os cinematógrafos falantes 1902-1908). (versão integral). Mnemocine, 2006b. Disponível em: $<$ http://www.mnemocine.com.br/index.php/cinema-categoria/25-historia-no-cinema-historiado-cinema/121-primeiras-tentativas-de-sonorizacao-no-cinema-brasileiro-os-cinematografosfalantes-1902-1908>. Acesso em 07 de jul. 2012.

, Fernando Morais da. Que papel é delegado ao som, em um meio audiovisual? A imagem preponderante, e a inserção do som no cinema. Ecos Revista, Pelotas - RS, v. 7, n. 1, p. 71-91, 2003e.

FREIRE, Rafael de Luna. "Versão brasileira" - Contribuições para uma história da dublagem cinematográfica no Brasil nas décadas de 1930 e 1940. Ciberlegenda (UFF. Online), n.24, v. 1, p. 7-18, 2011.

GATTI, Andre Piero; MENDES, Eduardo Santos. A nova sonoridade do cinema em São Paulo. In: André Piero Gatti. (Org.). O novo cinema paulista. 1 ed. São Paulo: Centro Cultural São Paulo, 2008, v. 05, p. 43-64.

HAUSSEN, Luciana. Som, Câmera, Ação: a relevância do som na história do cinema. Sessões do Imaginário (Impresso), v. 20, p. 17-22. Porto Alegre, 2008.

\section{TECNOLOGIA}

\section{Dissertações:}

ALVAREZ, Mariano Gabriel. A Estereofonia Digital: uma abordagem sobre a técnica, o padrão e a linguagem sonora cinematográfica norte-americana no período de 1991 a 2001. Dissertação (Mestrado em Ciências da Comunicação). USP. São Paulo, 2007.

COSTA, Nélio José Batista. O surround e a espacialidade sonora no cinema. Dissertação (Mestrado em Artes Visuais). UFMG. Belo Horizonte, 2004a.

\section{Artigos:}

PEDREIRAS, Aline Riera. O som surround e suas formas de uso. Revista Sonora, vol. 1 (1), UNICAMP, 2008. 


\section{PERCEPCX̃̃O SONORA}

\section{Dissertações:}

CARVAlHO, Andreson Silva de. A Percepção Sonora no Cinema: ver com os ouvidos, ouvir com outros sentidos. Dissertação (Mestrado em Comunicação). UFF. Rio de Janeiro, 2009.

CASTANHEIRA. José Cláudio Siqueira. A Paisagem Sonora Eletrônica: a construção de novas audibilidades no cinema. Dissertação (Mestrado em Comunicação Social). UERJ. Rio de Janeiro, 2010a.

FLORES, Virginia Osorio. O Cinema, uma arte sonora. Dissertação (Mestrado em Música) UFRJ. Rio de Janeiro, 2006.

\section{Artigos:}

CASTANHEIRA, José Cláudio Siqueira. A Paisagem Sonora Eletrônica: a reconstrução do mundo sonoro contemporâneo no cinema. Contemporânea: revista de Comunicação e Cultura. Rio de Janeiro, vol. 06, 2008a.

, José Cláudio Siqueira. A Presença do Som: proposta para uma investigação material da experiência sonora no cinema. Contemporânea: revista de Comunicação e Cultura. Rio de Janeiro, vol. 07, $\mathrm{n}^{\circ}$ 06, 2009b.

, José Cláudio Siqueira. Electronic Tonalities: o espaço eletrônico e a impressão de realidade na ficção científica. Contemporânea: revista de Comunicação e Cultura. Rio de Janeiro, vol. 11, 2008 b.

, José Cláudio Siqueira. O Som Eletrônico no Cinema: uma abordagem fenomenológica. Contemporânea: revista de Comunicação e Cultura. Ed 15: Rio de Janeiro, vol. $8, \mathrm{n} 2,2010 \mathrm{~b}$.

, José Cláudio Siqueira. O Som Expandido: os novos espaços do som no cinema. Revista de Estudos da Comunicação, v. 12, p. 265-273, 2011 b.

, José Cláudio Siqueira. Pré-escutas: modelos de audibilidades dos primeiros cinemas.

Entre.Meios, v. 6, 2009a.

COSTA, Fernando Morais da. Escutar tanto quanto se vê (como um filme iraniano, sobre uma criança cega, pode ensinar a ouvir?). In: Anais do XXVI Congresso brasileiro de ciências da comunicação - INTERCOM. Belo Horizonte, 2003b.

FLORES, Virginia Osorio. A Escuta Fílmica: uma atitude estética. XVII Congresso da Associação Nacional de Pesquisa e Pós-graduação em Música (ANPPOM). São Paulo, 2007. 


\section{PROCESSO DE CRIACÃ̃O}

Teses:

SOUZA, João B. G. de. Procedimentos de trabalho na captação de som direto nos longasmetragens brasileiros Contra todos e Antônia: a técnica e o espaço criativo. Tese (Doutorado em Ciências da Comunicação) - Escola de Comunicações e Artes, USP, São Paulo, 2011.

\section{Dissertações:}

ESPOSITO, Mauricio de Caro. Criando Mundo com Sons: Pós-produção de som e sound design no cinema. Dissertação (Mestrado em Comunicação). Universidade Anhembi Morumbi. São Paulo, 2011.

OPOLSKI, Débora Regina. Análise do design sonoro no longa-metragem Ensaio Sobre a Cegueira. Dissertação (Mestrado em Música). UFPR. Curitiba, 2009a.

PEREIRA, Kira Santos. Se Podes Ouvir, Escuta: a gênese audiovisual de Ensaio Sobre a Cegueira. Dissertação (Mestrado em Comunicação). USP. São Paulo, 2010.

\section{Artigos:}

ALVES, Bernardo Marquez. Produção Sonora no Cinema Contemporâneo: um olhar sobre desafios do som no cinema brasileiro e o processo de finalização de som do filme Tropa de Elite 2. Revista Cinema Caipira, n. 31. Rio Claro, setembro de 2011.

BOZICANIN, José Eduardo. As idéias da trilha sonora do filme Akira. RUA - Revista Universitária do Audiovisual, v. 4, p. 12, 2008. Disponível em:

$<$ http://www.ufscar.br/rua/site/?p=163>. Acesso em 30 jul. 2011.

LEME, Gerson Rios. Escutando o Cinema. RUA - Revista Univesitária do Audiovisual, v. 02, p. 145, 2008. Disponível em: <http://www.ufscar.br/rua/site/?p=145> . Acesso em 30 jul. 2011.

PEREIRA, Kira Santos. Se Podes Ouvir, Escuta: relações audiovisuais do filme Ensaio Sobre a Cegueira e considerações sobre seu processo criativo. RUA - Revista Universitária do Audiovisual, p. 1-2, 2009b. Disponível em: $<$ http://www.rua.ufscar.br/site/?p=1680>. Acesso em 30 jul. 2011.

VEDANA, Viviane. Diálogos sobre a imagem visual e a imagem sonora: a experiência de escritura do sonoro nos documentários etnográficos. Ciberlegenda (UFF. Online), n.24, v. 1, p. 29-42, 2011. 


\section{ELEMENTOS DA TRILHA SONORA}

\section{Dissertação:}

BRÄUTIGAM, Alexandre Baliú. Sonologia e Cinema: elementos para análise áudio-visual. Dissertação (Mestrado em Música). UFRJ. Rio de Janeiro, 2007.

\section{Artigos:}

LEME, Gerson Rios. Pensando a trilha sonora para audiovisual. ORSON - Revista dos Cursos de Cinema do Cearte UFPEL, v. 1, p. 89-95, 2011.

SILVA, Márcia Regina Carvalho da. De olhos e ouvidos bem abertos: uma classificação dos sons no cinema. Revista NAU - Revista de Comunicação Audiovisual da Intercom, São Paulo, v.1, n.2, p.199-216, ago/dez 2008.

SILVA, Márcia Regina Carvalho da. A Trilha Sonora do Cinema: proposta para um "ouvir" analítico. Caligrama: Revista de Estudos e Pesquisa em Linguagem e Mídia. São Paulo, vol. 03, no 01, 2007.

\section{ESTUDOS DA VOZ}

Teses:

DÖPPENSCHMITT, Elen Cristina Souza Koch Vaz. Por uma política da voz no cinema: estratégias para emancipação do espectador em Memórias do Subdesenvolvimento de Tomás Gutiérrez. Tese (Doutorado em Comunicação e Semiótica). PUC. São Paulo, 2010.

\section{Dissertações:}

AMARAL, Vitória Rocha Prado. A voz na mise en scène: o filme Cidade de Deus sob a escuta fonoaudiológica. Dissertação (Mestrado em Fonoaudiologia). PUC-SP. São Paulo, 2006.

CASTRO, Luciana. Análise dos Padrões de Voz no Cinema: a comunicação oral humana em duas versões de The Nutty Professor. Dissertação (Mestrado em Educação em Ciências e Saúde). UFRJ. Rio de Janeiro, 2001.

DÖPPENSCHMITT, Elen Cristina Souza. Um Estudo da Performance da Oralidade no Cinema: registros da voz na linguagem documental. Dissertação (Mestrado em Comunicação e Semiótica). PUC. São Paulo, 2005.

SOUZA, Priscila Haydée. Expressividade oral no cinema: diálogos com a fonoaudiologia. Dissertação (Mestrado em Fonoaudiologia). PUC. São Paulo, 2010. 


\section{Artigos:}

AMARAL, Vitoria Rocha Prado; FERREIRA, Léslie Piccolotto; MARTZ, Maria Laura Wey; SOUZA, Priscila Haydée. Representações de Voz e Fala no Cinema. Galáxia, v. 10, p. 151164, $2010 \mathrm{~b}$.

, Vitoria Rocha Prado; FERREIRA, Léslie Piccolotto; SOUZA, Priscila Haydée. A Fonoaudiologia e o ator de cinema: relatos de profissionais do meio cinematográfico. Distúrbios da Comunicação, v. 22, p. 133-147, 2010a.

COSTA, Fernando Morais da. São Bernardo: mosaico de vozes (mostruário dos diversos usos da voz no cinema). In: CATANI, Afrânio Mendes et al. (Org.). Estudos Socine de cinema, Ano IV. São Paulo: Panorama, 2003c, v. , p. 345-350.

DOPPENSCHMITT, Elen. Por uma Política da Voz: Tomás Gutiérrez Alea e as Memórias do Subdesenvolvimento. Devires (UFMG), v. 5, p. 184-203, 2008.

, Elen. A voz nas Memórias do Subdesenvolvimento: de Edmundo Desnoes a Tomás Gutiérrez Alea. In: Anais do XI Encontro Regional da Associação Brasileira de Literatura Comparada (ABRALIC). São Paulo, 2007a.

, Elen. Voz e Canto Popular do Negro no Cinema - poética cinematográfica no documentário Adão ou Somos Todos Filhos da Terra de Walter Salles e Daniela Thomas. UNIMONTES Científica, v. 8, p. 41-50, 2007b.

LINS, Consuelo. O ensaio no documentário e a questão da narração em off. In: XVI Encontro Nacional da Compós, 2007, Curitiba. Anais do XVI Encontro Nacional da Compós. Curitiba: Tuiuti/Compós, 2007.

MIRANDA, Suzana Reck. Vozes Polifônicas e Escutas Musicais: a articulação da banda sonora em François Girard. In: Machado, Jr. R.; Soares, R. De L.; Araújo, L. C. de. (Org.). Estudos de Cinema - Socine VIII. São Paulo: Anna Blume, 2007, v.1, p. 41-48.

\section{ESTUDOS DO RUÍDO}

Artigos:

COSTA, Fernando Morais da. Pode o cinema contemporâneo representar o ambiente sonoro em que vivemos? Logos: Comunicação \& Universidade. Rio de Janeiro, vol. 17, $\mathrm{n}^{\circ} 32$, $2010 \mathrm{~b}$.

CUNHA, Damyler Ferreira. A Submersão nas Imagens Sonoras: o som e suas dimensões reais e imaginárias. Revista Rumores. Ed. 9, vol 1, São Paulo, janeiro-junho de 2011.

OPOLSKI, Debora Regina. A paisagem sonora e a ambientação do desenho de som: Os Sons ambiente como localizadores espaciais e temporais no filme Ensaio Sobre a Cegueira. In: MusiMid, 2009, São Paulo. Anais do $5^{\circ}$ Encontro de Música e Mídia: Estéticas do Som, 2009b. p. 1-18. 


\section{ESTUDOS DO SILÊNCIO}

\section{Artigos:}

COSTA, Fernando Morais da. Os caminhos dos usos dos silêncios (ou a lembrança que não passa de John Cage). Ciberlegenda (UFF. Online), Niterói, 24 jul. 2011c. Disponível em: $<$ http://www.proppi.uff.br/ciberlegenda/os-caminhos-dos-usos-dos-sil\%C3\%AAncios>. Acesso em 30 jul. 2011.

, Fernando Morais da. Se pouco se diz sobre o som, quem fala sobre o silêncio nos filmes?. Gragoatá - Revista do Programa de Pós-Graduação em Letras UFF, Niterói, v. 16, p. 105-116, 2004b.

\section{TEORIA}

\section{Artigos:}

CASTANHEIRA, José Cláudio Siqueira. O soundscape da modernidade: os Sound Studies e o som no cinema. In: Laura Cánepa; Adalberto Müller; Gustavo Souza; Marcel Vieira. (Org.). XII Estudos de Cinema e Audiovisual (SOCINE). São Paulo: Socine, 2011a, v. 2, p. 325338.

MENDES, Eduardo Santos. Pensando a Relação Imagem-Som. TEOREMA - Crítica de Cinema, Porto Alegre, v. 5, p. 51-55, 2004.

\section{ESTÉTICA E ESTILO}

\section{Dissertação:}

PESSOA, Frederico Augusto Vianna de Assis. O Lugar Fora do Lugar: topografias sonoras do cinema documentário. Dissertação (Mestrado em Artes). UFMG, Belo Horizonte, 2011.

\section{Artigos:}

CARREIRO, Rodrigo. Sobre o som no cinema de horror: padrões recorrentes de estilo. Ciberlegenda (UFF. Online), n.24, v. 1, p. 29-42, 2011 b.

COSTA, Fernando Morais da. Como soa hoje experimental?. Filme Cultura, v. 54, p. 49-54, $2011 b$.

, Fernando Morais da. Pode-se dizer que há algo como um hiper-realismo sonoro no cinema argentino?. Ciberlegenda (UFF. Online), n.24, v. 1, p. 84-90, 2011 a.

, Fernando Morais da. Ruídos e silêncio: proposta para uma estética do som no cinema. In: FABRIS, Mariarosaria et al. (Org.). Estudos Socine de cinema, Ano III. Porto Alegre: Sulina, 2003d, v. , p. 313-319. 
COSTA, Fernando Morais da. Som e ritmo interno no plano-sequência. XI Estudos de Cinema e Audiovisual (SOCINE). São Paulo, vol. 11, 2010a.

\section{ESTUDOS DE CASO}

Livros:

MANZANO, Luiz Adelmo Fernandes. Som-imagem no cinema: a experiência alemã de Fritz Lang. São Paulo: Perspectiva: FAPESP, 2003.

\section{Dissertações:}

ASPAHAN, Pedro Cardoso. Entre a escuta e a visão: o lugar do espectador na obra de Robert Bresson. Dissertação (Mestrado em Comunicação Social). UFMG. Belo Horizonte, 2008 .

BARRENHA, Natalia C. A experiência do cinema de Lucrecia Martel: resíduos do tempo e sons à beira da piscina. Dissertação (Mestrado em Multimeios). UNICAMP, Campinas, 2011.

COSTA, Fernando Morais da. Som no Cinema, Silêncio nos Filmes: o inexplorado e o inaudito. Dissertação (Mestrado em Comunicação Social). UFF. Rio de Janeiro, 2003a.

MARCOLINO, Márcio Cardoso. O Compositor Stanley Kubrick: análise do som do filme De olhos bem fechados de Stanley Kubrick através da teoria sonora de Michel Chion. Dissertação (Mestrado em Artes). UFMG. Belo Horizonte, 2008.

\section{Artigos:}

ALMEIDA, Natasha Hernandez. O artista silencioso: um estudo da construção sonora no filme do Cineclube Universitário de Campinas. CoMtempo (Revista Eletrônica do Programa de Pós-graduação em Comunicação da Faculdade Cásper Líbero), vol. 2, n2, ano 3. São Paulo, dez. 2011.

ALVIM, Luiza B. A. M.. Paisagens sonoras de Robert Bresson. Ciberlegenda (UFF. Online), n.24, v. 01, p. 62-72, 2011.

BARRENHA, Natalia C.; PASSOS, Antônio Fernando da Conceição. À beira da piscina, à beira do quadro: A utilização do som off e a construção de tensão na obra de Lucrecia Martel. XXXII Congresso Brasileiro de Ciências da Comunicação (INTERCOM). Curitiba, 4 a 7 de setembro de 2009.

CALEIRO, Mauricio. A narrativa fonocinematográfica em $O$ Silêncio: audição subjetiva e cronotopias do espaço fílmico. Ciberlegenda (UFF. Online), n.24, v. 1, p. 138-148, 2011.

CARREIRO, Rodrigo. O rádio e os silêncios: articulações sobre o uso do som em Cinema, Aspirinas e Urubus. XI Estudos de Cinema e Audiovisual (SOCINE). São Paulo, vol. 11, 2010a. 
CARREIRO, Rodrigo. Os sons da continuidade intensificada: o caso de Sergio Leone. In: Laura Cánepa; Adalberto Müller; Gustavo Souza; Marcel Vieira. (Org.). XII Estudos de Cinema e Audiovisual (SOCINE). 1ed.São Paulo: Socine, 2011a, v. 2, p. 354-369.

, Rodrigo. Relações entre imagens e sons no filme Cinema, Aspirinas e Urubus. Revista da Associação Nacional dos Programas de Pós-Graduação em Comunicação Ecompós, Brasília, v.13, nº 1, 2010 b.

DOBAL, Suzana M. Robert Bresson: o cinema num atormentado silêncio. In: FABRIS, Mariarosaria et al. (Org.). Estudos Socine de cinema, Ano III. Porto Alegre: Sulina, 2003, v. , p. 275-281.

MENDES, Eduardo Santos; CARRASCO, Claudiney. A relação imagem/som nos filmes de Kubrick. Revista Cult, São Paulo, p. 55 - 59, 01 out. 2007.

, Eduardo Santos; PINTO, Ivonete. Lucrecia Martel e o benefício da incerteza. TEOREMA - Crítica de Cinema, Porto Alegre, v. 8, 2005.

, Eduardo Santos. Walter Murch: a revolução da trilha sonora cinematográfica. In: Significação no 26, p. 187-224. São Paulo: Annablume, 2006.

PEREIRA, Kira Santos. Candinho: a construção do espaço narrativo através da relação imagem-som. RUA - Revista Universitária Audiovisual. São Carlos, 2009a. Disponível em: $<$ http://www.ufscar.br/rua/site/?p=1619>. Acesso em 30 jul. 2011.

PIPANO, Isaac. Além do que se vê - o som e as paisagens sonoras no documentário Dong, de Jia Zhang-ke. Ciberlegenda (UFF. Online), n.24, v.1, p. 73 / 07-83, 2011.

QUINTANA, Fabiana. A Trilha sonora de um filme imaginário: Uma análise do filme BLUE (1993) de Derek Jarman. In: $6^{0}$ Encontro de Música e Mídia (MusiMid). São Paulo : Letra e Voz, 2010.

, Fabiana. Orfeu: do mito a realidade brasileira. A importância da trilha sonora na estratégia narrativa de Cacá Diegues e sua relação com o contexto sociocultural de uma época. In: $5^{\circ}$ Encontro de Música e Mídia (MusiMid). Santos: Realejo Livros e Edições, 2009.

RODRIGUES, Rodrigo Fonseca e. Sonoridades do cinema: Tarkovsky e a heterocronia da escuta. Mediação (Belo Horizonte), v. 13, p. 113-122, 2011.

TORRES, Alfredo Werney Lima. A Sinfonia dos Pássaros. RUA - Revista Universitária do Audiovisual. São Carlos, 2009. Disponível em: <http://www.ufscar.br/rua/site/? p=2194\#_ftn1>. Acesso em 30 jul. 2011.

VENANCIO, Rafael D. O.. Efeitos sonoros enquanto fala audiovisual: Análise de Gerald McBoing-Boing à luz do $§ 528$ das Investigações Filosóficas. Ciberlegenda (UFF. Online), n.24, v. 1, p. 126-137, 2011. 
ANEXO III:

Lista bibliográfica de teses e dissertações distribuídas por Universidade.

$\underline{\text { USP }}$

Teses:

MANZANO, Luiz Adelmo Fernandes. O som no cinema: da edição de som ao sound design - evolução tecnológica e produção brasileira. Tese (Doutorado em Ciências da Comunicação). USP. São Paulo, 2005.

SOUZA, João B. G. de. Procedimentos de trabalho na captação de som direto nos longasmetragens brasileiros Contra todos e Antônia: a técnica e o espaço criativo. Tese (Doutorado em Ciências da Comunicação) - Escola de Comunicações e Artes, USP, São Paulo, 2011.

\section{Dissertações:}

BARBOSA, Ana Luiza Pereira. A relação som-imagem nos filmes de animação norteamericanos no final da década de 1920: do silencioso ao sonoro. Dissertação (Mestrado em Ciências da Comunicação). USP. São Paulo, 2009.

ALVAREZ, Mariano Gabriel. A Estereofonia Digital: Uma abordagem sobre a técnica, o padrão e a linguagem sonora cinematográfica norte-americana no período de 1991 a 2001. Dissertação (Mestrado em Ciências da Comunicação). USP. São Paulo, 2007.

GUIMARÃES, Clotilde Borges. A introdução do som direto no cinema documentário brasileiro na década de 1960. Dissertação (Mestrado em Ciências da Comunicação). USP. São Paulo, 2008.

PEREIRA, Kira Santos. Se Podes Ouvir, Escuta: a gênese audiovisual de Ensaio Sobre a Cegueira. Dissertação (Mestrado em Ciências da Comunicação). USP. São Paulo, 2010.

\section{$\underline{\text { UFMG }}$}

Teses:

WERNECK, Daniel Leal. Movimentos Invisíveis: história da estética do som do cinema de animação. Tese (Doutorado em Artes). UFMG. Belo Horizonte, 2010.

\section{Dissertações:}

COSTA, Nélio José Batista. O surround e a espacialidade sonora no cinema. Dissertação (Mestrado em Artes). UFMG. Belo Horizonte, 2004a.

PESSOA, Frederico Augusto V. de A.. O Lugar Fora do Lugar: topografias sonoras do cinema documentário. Dissertação (Mestrado em Artes). UFMG, Belo Horizonte, 2011. 
ASPAHAN, Pedro Cardoso. Entre a escuta e a visão: o lugar do espectador na obra de Robert Bresson. Dissertação (Mestrado em Comunicação Social). UFMG. Belo Horizonte, 2008.

MARCOLINO, Márcio Cardoso. O Compositor Stanley Kubrick: análise do som do filme De olhos bem fechados de Stanley Kubrick através da teoria sonora de Michel Chion. Dissertação (Mestrado em Artes). UFMG. Belo Horizonte, 2008.

\section{$\underline{\text { PUC-SP }}$}

Teses:

DÖPPENSCHMITT, Elen Cristina Souza Koch Vaz. Por uma Política da Voz no Cinema: estratégias para emancipação do espectador em Memórias do Subdesenvolvimento de Tomás Gutiérrez. Tese (Doutorado em Comunicação e Semiótica). PUC. São Paulo, 2010.

\section{Dissertações:}

SOUZA, Priscila Haydée. Expressividade oral no cinema: diálogos com a fonoaudiologia. Dissertação (Mestrado em Fonoaudiologia). PUC. São Paulo, 2010.

AMARAL, Vitória Rocha Prado. A voz na mise en scène: o filme Cidade de Deus sob a escuta fonoaudiológica. Dissertação (Mestrado em Fonoaudiologia). PUC-SP. São Paulo, 2006.

DÖPPENSCHMITT, Elen Cristina Souza. Um Estudo da Performance da Oralidade no Cinema: registros da voz na linguagem documental. Dissertação (Mestrado em Comunicação e Semiótica). PUC. São Paulo, 2005.

\section{UFF}

Teses:

COSTA, Fernando Morais da. O som no cinema brasileiro: revisão de uma importância indeferida. Tese (Doutorado em Comunicação). UFF. Rio de Janeiro, 2006.

\section{Dissertações:}

CAPELLER, Ivan. Introdução à arqueologia da escuta ou o nascimento do cinema sonoro a partir do espírito da ópera. Dissertação (Mestrado em Comunicação). UFF. Rio de Janeiro, 2005.

CARVAlHO, Andreson Silva de. A Percepção Sonora no Cinema: ver com os ouvidos, ouvir com outros sentidos. Dissertação (Mestrado em Comunicação). UFF. Rio de Janeiro, 2009. 
COSTA, Fernando Morais da. Som no Cinema, Silêncio nos Filmes: o inexplorado e o inaudito. Dissertação (Mestrado em Comunicação). UFF. Rio de Janeiro, 2003a.

\section{UFRJ}

\section{Dissertações:}

FLORES, Virginia Osorio. O Cinema, uma arte sonora. Dissertação (Mestrado em Música) UFRJ. Rio de Janeiro, 2006.

BRÄUTIGAM, Alexandre Baliú. Sonologia e Cinema: elementos para análise áudio-visual. Dissertação (Mestrado em Música). UFRJ. Rio de Janeiro, 2007.

CASTRO, Luciana. Análise dos Padrões de Voz no Cinema: a comunicação oral humana em duas versões de The Nutty Professor. Dissertação (Mestrado em Educação em Ciências e Saúde). UFRJ. Rio de Janeiro, 2001.

\section{$\underline{\text { UFPR }}$}

\section{Dissertações:}

OPOLSKI, Débora Regina. Análise do design sonoro no longa-metragem Ensaio Sobre a Cegueira. Dissertação (Mestrado em Música). UFPR. Curitiba, 2009a.

\section{$\underline{\text { UERJ }}$}

\section{Dissertações:}

CASTANHEIRA. José Cláudio Siqueira. A Paisagem Sonora Eletrônica: a construção de novas audibilidades no cinema. Dissertação (Mestrado em Comunicação Social). UERJ. Rio de Janeiro, 2010a.

\section{UNICAMP}

BARRENHA, Natalia C. A experiência do cinema de Lucrecia Martel: resíduos do tempo e sons à beira da piscina. Dissertação (Mestrado em Multimeios). UNICAMP, Campinas, 2011.

\section{$\underline{\text { UAM }}$}

\section{Dissertações:}

ESPOSITO, Mauricio de Caro. Criando Mundo com Sons: Pós-produção de som e sound design no cinema. Dissertação (Mestrado em Comunicação). Universidade Anhembi Morumbi. São Paulo, 2011. 
ANEXO IV:

Lista bibliográfica de teses e dissertações distribuídas por Área e Programa de Pós-Graduação

\section{COMUNICAÇÃO}

\section{Ciências da Comunicação / USP}

Teses:

MANZANO, Luiz Adelmo Fernandes. O som no cinema: da edição de som ao sound design - evolução tecnológica e produção brasileira. Tese (Doutorado em Ciências da Comunicação). USP. São Paulo, 2005.

SOUZA, João B. G. de. Procedimentos de trabalho na captação de som direto nos longasmetragens brasileiros Contra todos e Antônia: a técnica e o espaço criativo. Tese (Doutorado em Ciências da Comunicação) - Escola de Comunicações e Artes, USP, São Paulo, 2011.

\section{Dissertações:}

ALVAREZ, Mariano Gabriel. A Estereofonia Digital: Uma abordagem sobre a técnica, o padrão e a linguagem sonora cinematográfica norte-americana no período de 1991 a 2001. Dissertação (Mestrado em Ciências da Comunicação). USP. São Paulo, 2007.

BARBOSA, Ana Luiza Pereira. A relação som-imagem nos filmes de animação norteamericanos no final da década de 1920: do silencioso ao sonoro. Dissertação (Mestrado em Ciências da Comunicação). USP. São Paulo, 2009.

GUIMARÃES, Clotilde Borges. A introdução do som direto no cinema documentário brasileiro na década de 1960. Dissertação (Mestrado em Ciências da Comunicação). USP. São Paulo, 2008.

PEREIRA, Kira Santos. Se Podes Ouvir, Escuta: A gênese audiovisual de Ensaio Sobre a Cegueira. Dissertação (Mestrado em Ciências da Comunicação). USP. São Paulo, 2010.

\section{Comunicação / UFF}

Teses:

COSTA, Fernando Morais da. O som no cinema brasileiro: revisão de uma importância indeferida. Tese (Doutorado em Comunicação). UFF. Rio de Janeiro, 2006.

\section{Dissertações:}

CAPELLER, Ivan. Introdução à arqueologia da escuta ou o nascimento do cinema sonoro a partir do espírito da ópera. Dissertação (Mestrado em Comunicação). UFF. Rio de Janeiro, 2005. 
CARVAlHO, Andreson Silva de. A Percepção Sonora no Cinema: ver com os ouvidos, ouvir com outros sentidos. Dissertação (Mestrado em Comunicação). UFF. Rio de Janeiro, 2009.

COSTA, Fernando Morais da. Som no Cinema, Silêncio nos Filmes: o inexplorado e o inaudito. Dissertação (Mestrado em Comunicação). UFF. Rio de Janeiro, 2003a.

\section{Comunicacão e Semiótica / PUC-SP}

Teses:

DÖPPENSCHMITT, Elen Cristina Souza Koch Vaz. Por uma Política da Voz no Cinema: estratégias para emancipação do espectador em Memórias do Subdesenvolvimento de Tomás Gutiérrez. Tese (Doutorado em Comunicação e Semiótica). PUC. São Paulo, 2010.

\section{Dissertações:}

DÖPPENSCHMITT, Elen Cristina Souza. Um Estudo da Performance da Oralidade no Cinema: registros da voz na linguagem documental. Dissertação (Mestrado em Comunicação e Semiótica). PUC. São Paulo, 2005.

\section{Comunicação Social / UFMG}

\section{Dissertações:}

ASPAHAN, Pedro Cardoso. Entre a escuta e a visão: o lugar do espectador na obra de Robert Bresson. Dissertação (Mestrado em Comunicação Social). UFMG. Belo Horizonte, 2008.

\section{Comunicação Social / UERJ}

\section{Dissertações:}

CASTANHEIRA. José Cláudio Siqueira. A Paisagem Sonora Eletrônica: a construção de novas audibilidades no cinema. Dissertação (Mestrado em Comunicação Social). UERJ. Rio de Janeiro, 2010a.

\section{Comunicação / UAM}

\section{Dissertações:}

ESPOSITO, Mauricio de Caro. Criando Mundo com Sons: Pós-produção de som e sound design no cinema. Dissertação (Mestrado em Comunicação). Universidade Anhembi Morumbi. São Paulo, 2011. 


\section{Multimeios / UNICAMP}

Dissertações:

BARRENHA, Natalia C. A experiência do cinema de Lucrecia Martel: resíduos do tempo e sons à beira da piscina. Dissertação (Mestrado em Multimeios). UNICAMP, Campinas, 2011.

\section{ARTES (ARTES/MÚSICA)}

\section{$\underline{\text { Artes / UFMG }}$}

Teses:

WERNECK, Daniel Leal. Movimentos Invisíveis: história da estética do som do cinema de animação. Tese (Doutorado em Artes). UFMG. Belo Horizonte, 2010.

\section{Dissertações:}

MARCOLINO, Márcio Cardoso. O Compositor Stanley Kubrick: análise do som do filme De olhos bem fechados de Stanley Kubrick através da teoria sonora de Michel Chion. Dissertação (Mestrado em Artes). UFMG. Belo Horizonte, 2008.

COSTA, Nélio José Batista. O surround e a espacialidade sonora no cinema. Dissertação (Mestrado em Artes). UFMG. Belo Horizonte, 2004a.

PESSOA, Frederico Augusto Vianna de Assis. O Lugar Fora do Lugar: topografias sonoras do cinema documentário. Dissertação (Mestrado em Artes). UFMG, Belo Horizonte, 2011.

\section{Música / UFRJ}

\section{Dissertações:}

FLORES, Virginia Osorio. O Cinema, uma arte sonora. Dissertação (Mestrado em Música) UFRJ. Rio de Janeiro, 2006.

BRÄUTIGAM, Alexandre Baliú. Sonologia e Cinema: elementos para análise áudio-visual. Dissertação (Mestrado em Música). UFRJ. Rio de Janeiro, 2007.

\section{Música / UFPR}

\section{Dissertações:}

OPOLSKI, Débora Regina. Análise do design sonoro no longa-metragem Ensaio Sobre a Cegueira. Dissertação (Mestrado em Música). UFPR. Curitiba, 2009a. 


\section{FONOAUDIOLOGIA}

\section{Fonoaudiologia / PUC-SP}

\section{Dissertações:}

SOUZA, Priscila Haydée. Expressividade oral no cinema: diálogos com a fonoaudiologia. Dissertação (Mestrado em Fonoaudiologia). PUC-SP. São Paulo, 2010.

AMARAL, Vitória Rocha Prado. A voz na mise en scène: o filme Cidade de Deus sob a escuta fonoaudiológica. Dissertação (Mestrado em Fonoaudiologia). PUC-SP. São Paulo, 2006.

\section{Educação em Ciências e Saúde / UFRJ}

\section{Dissertações:}

CASTRO, Luciana. Análise dos Padrões de Voz no Cinema: a comunicação oral humana em duas versões de The Nutty Professor. Dissertação (Mestrado em Educação em Ciências e Saúde). UFRJ. Rio de Janeiro, 2001. 


\section{ANEXO V:}

Lista bibliográfica de trabalhos que abordam questões relacionadas ao cinema brasileiro.

\section{$\underline{\text { Livros }}$}

COSTA, Fernando Morais. O som no cinema brasileiro. Rio de Janeiro: 7Letras: FAPERJ, 2008.

$\underline{\text { Teses }}$

COSTA, Fernando Morais. O som no cinema brasileiro: revisão de uma importância indeferida. Tese (Doutorado em Comunicação Social). UFF. Rio de Janeiro, 2006a.

MANZANO, Luiz Adelmo Fernandes. O som no cinema: da edição de som ao sound design - evolução tecnológica e produção brasileira. Tese (Doutorado em Comunicação e Estética do Audiovisual). USP. São Paulo, 2005.

SOUZA, João B. G. de. Procedimentos de trabalho na captação de som direto nos longasmetragens brasileiros Contra todos e Antônia: a técnica e o espaço criativo. Tese (Doutorado em Ciências da Comunicação) - Escola de Comunicações e Artes, Universidade de São Paulo, São Paulo, 2011.

\section{Dissertações}

AMARAL, Vitória Rocha Prado. A voz na mise en scène: o filme Cidade de Deus sob a escuta fonoaudiológica. Dissertação (Mestrado em Fonoaudiologia). PUC-SP. São Paulo, 2006.

DÖPPENSCHMITT, Elen Cristina Souza. Um Estudo da Performance da Oralidade no Cinema: registros da voz na linguagem documental. Dissertação (Mestrado em Comunicação e Semiótica). PUC. São Paulo, 2005.

ESPOSITO, Mauricio de Caro. Criando Mundo com Sons: Pós-produção de som e sound design no cinema. Dissertação (Mestrado em Comunicação). Universidade Anhembi Morumbi. São Paulo, 2011.

GUIMARÃES, Clotilde Borges. A introdução do som direto no cinema documentário brasileiro na década de 1960. Dissertação (Mestrado em Ciências da Comunicação). USP. São Paulo, 2008.

OPOLSKI, Débora Regina. Análise do design sonoro no longa-metragem Ensaio Sobre a Cegueira. Dissertação (Mestrado em Música). UFPR. Curitiba, 2009a.

PEREIRA, Kira Santos. Se Podes Ouvir, Escuta: A gênese audiovisual de Ensaio Sobre a Cegueira. Dissertação (Mestrado em Comunicação). USP. São Paulo, 2010. 


\section{$\underline{\text { Artigos }}$}

ALMEIDA, Natasha Hernandez. O artista silencioso: um estudo da construção sonora no filme do Cineclube Universitário de Campinas. CoMtempo (Revista Eletrônica do Programa de Pós-graduação em Comunicação da Faculdade Cásper Líbero), vol. 2, n2, ano 3. São Paulo, dez. 2011.

ALVES, Bernardo Marquez. Produção Sonora no Cinema Contemporâneo: um olhar sobre desafios do som no cinema brasileiro e o processo de finalização de som do filme "Tropa de Elite 2”. Revista Cinema Caipira. N 31. ISNN 1984-896X. Rio Claro, setembro de 2011.

CARREIRO, Rodrigo. O rádio e os silêncios: articulações sobre o uso do som em Cinema, Aspirinas e Urubus. XI Estudos de Cinema e Audiovisual (SOCINE). São Paulo, vol. 11, 2010a.

, Rodrigo. Relações entre imagens e sons no filme "Cinema, Aspirinas e Urubus". Revista da Associação Nacional dos Programas de Pós-Graduação em Comunicação Ecompós, Brasília, v.13, nº 1, 2010 b.

COSTA, Fernando Morais. Como soa hoje experimental?. Filme Cultura, v. 54, p. 49-54, $2011 b$.

, Fernando Morais. Primeiras tentativas de sonorização no cinema brasileiro (os cinematógrafos falantes 1902-1908). (versão integral). Mnemocine, 2006 b.

, Fernando Morais da. São Bernardo: mosaico de vozes (mostruário dos diversos usos da voz no cinema). In: CATANI, Afrânio Mendes et al. (Org.). Estudos Socine de cinema, Ano IV. São Paulo: Panorama, 2003c, v. , p. 345-350.

DOPPENSCHMITT, Elen. Voz e Canto Popular do Negro no Cinema - poética cinematográfica no documentário Adão ou Somos Todos Filhos da Terra de Walter Salles e Daniela Thomas. UNIMONTES Científica, v. 8, p. 41-50, $2007 \mathrm{~b}$.

FERREIRA, Léslie Piccolotto; AMARAL, Vitoria Rocha Prado; MARTZ, Maria Laura Wey;SOUZA, P.H.. Representações de Voz e Fala no Cinema. Galaxia, v. 10, p. 151-164, 2010a.

, Leslie Piccolotto; AMARAL, Vitoria Rocha Prado; SOUZA, P.H.. A Fonoaudiologia e o ator de cinema: relatos de profissionais do meio cinematográfico. Distúrbios da Comunicação, v. 22, p. 133-147, 2010 b.

FREIRE, Rafael de Luna. "Versão brasileira" - Contribuições para uma história da dublagem cinematográfica no Brasil nas décadas de 1930 e 1940. Ciberlegenda (UFF. Online), n.24, v. 1, p. 7-18, 2011.

GATTI, Andre Piero; MENDES, Eduardo S. dos Santos. A nova sonoridade do cinema em São Paulo. In: André Piero Gatti. (Org.). O novo cinema paulista. 1 ed. São Paulo: Centro Cultural São Paulo, 2008, v. 05, p. 43-64. 
LINS, Consuelo. O ensaio no documentário e a questão da narração em off. In: XVI Encontro Nacional da Compós, 2007, Curitiba. Anais do XVI Encontro Nacional da Compós. Curitiba: Tuiuti/Compós, 2007.

OPOLSKI, Debora Regina. A paisagem sonora e a ambientação do desenho de som: Os Sons ambiente como localizadores espaciais e temporais no filme Ensaio Sobre a Cegueira. In: Musimid, 2009, São Paulo. Anais do $5^{\circ}$ Encontro de Música e Mídia: Estéticas do Som, 2009b. p. 1-18.

PEREIRA, Kira. Candinho: a construção do espaço narrativo através da relação imagem-som. RUA - Revista Universitária Audiovisual. São Carlos, 2009a. Disponível em: $<$ http://www.ufscar.br/rua/site/?p=1619>. Acesso em 30 jul. 2011.

Kira Santos. Se Podes Ouvir, Escuta: relações audiovisuais do filme Ensaio Sobre a Cegueira e considerações sobre seu processo criativo. RUA - Revista Universitária do Audiovisual, v. \#00, p. 1-2, 2009b. <http:/www.rua.ufscar.br/site/?p=1680>

QUINTANA, Fabiana. Orfeu: do mito a realidade brasileira. A importância da trilha sonora na estratégia narrativa de Cacá Diegues e sua relação com o contexto sociocultural de uma época. In: $5^{\mathbf{0}}$ Encontro de Música e Mídia (MUSIMID). Santos : Realejo Livros e Edições, 2009.

VEDANA, Viviane. Diálogos sobre a imagem visual e a imagem sonora: a experiência de escritura do sonoro nos documentários etnográficos. Ciberlegenda (UFF. Online), n.24, v. 1, p. 29-42, 2011. 


\section{ANEXO VI:}

Lista bibliográfica de artigos distribuídos por revista

\section{Livros dos Encontros da SOCINE}

CARREIRO, Rodrigo. O rádio e os silêncios: articulações sobre o uso do som em Cinema, aspirinas e urubus. XI Estudos de Cinema e Audiovisual (SOCINE). São Paulo, vol. 11, 2010a.

, Rodrigo. Os sons da continuidade intensificada: o caso de Sergio Leone. In: Laura Cánepa; Adalberto Müller; Gustavo Souza; Marcel Vieira. (Org.). XII Estudos de Cinema e Audiovisual (SOCINE). 1ed.São Paulo: Socine, 2011a, v. 2, p. 354-369.

CASTANHEIRA, José Cláudio Siqueira. O soundscape da modernidade: os Sound Studies e o som no cinema. In: Laura Cánepa; Adalberto Müller; Gustavo Souza; Marcel Vieira. (Org.). XII Estudos de Cinema e Audiovisual (SOCINE). São Paulo: Socine, 2011a, v. 2, p. 325338.

COSTA, Fernando Morais da. São Bernardo: mosaico de vozes (mostruário dos diversos usos da voz no cinema). In: CATANI, Afrânio Mendes et al. (Org.). Estudos Socine de cinema, Ano IV. São Paulo: Panorama, 2003c, v. , p. 345-350.

, Fernando Morais da. Ruídos e silêncio: proposta para uma estética do som no cinema. In: FABRIS, Mariarosaria et al. (Org.). Estudos Socine de cinema, Ano III. Porto Alegre: Sulina, 2003d, v. , p. 313-319.

, Fernando Morais da. Som e ritmo interno no plano-sequência. XI Estudos de Cinema e Audiovisual (SOCINE). São Paulo, vol. 11, 2010a.

DOBAL, Suzana M. Robert Bresson: o cinema num atormentado silêncio. In: FABRIS, Mariarosaria et al. (Org.). Estudos Socine de cinema, Ano III. Porto Alegre: Sulina, 2003, v. , p. 275-281.

MIRANDA, Suzana Reck. Vozes Polifônicas e Escutas Musicais: a articulação da banda sonora em François Girard. In: Machado, Jr. R.; Soares, R. De L.; Araújo, L. C. de. (Org.). Estudos de Cinema - SOCINE VIII. São Paulo: Anna Blume, 2007, v.1, p. 41-48.

\section{Anais da INTERCOM}

BARRENHA, Natalia C.; PASSOS, Antônio Fernando da Conceição. À beira da piscina, à beira do quadro: A utilização do som off e a construção de tensão na obra de Lucrecia Martel. XXXII Congresso Brasileiro de Ciências da Comunicação (INTERCOM). Curitiba, 4 a 7 de setembro de 2009.

COSTA, Fernando Morais da. Escutar tanto quanto se vê (como um filme iraniano, sobre uma criança cega, pode ensinar a ouvir?). In: Anais do XXVI Congresso brasileiro de ciências da comunicação - INTERCOM. Belo Horizonte, 2003b. 


\section{Anais do Encontro Nacional da Rede Alfredo de Carvalho}

BELLEBONI, Luciene. A difícil relação entre imagem e som no audiovisual contemporânea. In: Anais do II Encontro Nacional da Rede Alfredo de Carvalho, UFSC-Florianópolis, 2004.

COSTA, Fernando Morais da. A inserção do som no cinema: percalços na passagem de um meio visual para audiovisual. In: Anais do I Encontro Nacional da Rede Alfredo de Carvalho. Rio de Janeiro, $2003 \mathrm{f}$.

\section{$\underline{\text { Anais da MusiMid }}$}

OPOLSKI, Debora Regina. A paisagem sonora e a ambientação do desenho de som: Os Sons ambiente como localizadores espaciais e temporais no filme Ensaio Sobre a Cegueira. In: MusiMid, 2009, São Paulo. Anais do $5^{\circ}$ Encontro de Música e Mídia: Estéticas do Som, 2009b. p. 1-18.

QUINTANA, Fabiana. A Trilha sonora de um filme imaginário: Uma análise do filme BLUE (1993) de Derek Jarman. In: $6^{\mathbf{0}}$ Encontro de Música e Mídia (MusiMid). São Paulo : Letra e Voz, 2010.

Fabiana. Orfeu: do mito a realidade brasileira. A importância da trilha sonora na estratégia narrativa de Cacá Diegues e sua relação com o contexto sociocultural de uma época. In: $5^{\circ}$ Encontro de Música e Mídia (MusiMid). Santos: Realejo Livros e Edições, 2009.

\section{Anais da ANPPOM}

FLORES, Virginia Osorio. A Escuta Fílmica: uma atitude estética. XVII Congresso da Associação Nacional de Pesquisa e Pós-graduação em Música (ANPPOM). São Paulo, 2007.

\section{Anais da ABRALIC}

DÖPPENSCHMITT, Elen. A voz nas Memórias do Subdesenvolvimento: de Edmundo Desnoes a Tomás Gutiérrez Alea. In: Anais do XI Encontro Regional da Associação Brasileira de Literatura Comparada (ABRALIC). São Paulo, 2007a.

\section{Anais da COMPÓS}

LINS, Consuelo. O ensaio no documentário e a questão da narração em off. In: XVI Encontro Nacional da Compós, 2007, Curitiba. Anais do XVI Encontro Nacional da Compós. Curitiba: Tuiuti/Compós, 2007. 


\section{Revista CIBERLEGENDA}

ALVIM, Luiza B.A.M.. Paisagens sonoras de Robert Bresson. Ciberlegenda (UFF. Online), n.24, v. 01, p. 62-72, 2011

CALEIRO, Mauricio. A narrativa fonocinematográfica em $O$ Silêncio: audição subjetiva e cronotopias do espaço fílmico. Ciberlegenda (UFF. Online), n.24, v. 1, p. 138-148, 2011.

CAPELLER, Ivan. Introdução à Arqueologia da Escuta: do som e da voz como objetos de enunciação. Ciberlegenda (UFF. Online), n.24, v. 2, p. 7-15, 2011.

CARREIRO, Rodrigo. Sobre o som no cinema de horror: padrões recorrentes de estilo. Ciberlegenda (UFF. Online), n.24, v. 1, p. 29-42, 2011 b.

COSTA, Fernando Morais da. Pode-se dizer que há algo como um hiper-realismo sonoro no cinema argentino?. Ciberlegenda (UFF. Online), n.24, v. 1, p. 84-90, $2011 \mathrm{a}$.

, Fernando Morais da. Os caminhos dos usos dos silêncios (ou a lembrança que não passa de John Cage). Ciberlegenda (UFF. Online), Niterói, 24 jul. 2011c. Disponível em: $<$ http://www.proppi.uff.br/ciberlegenda/os-caminhos-dos-usos-dos-sil\%C3\%AAncios>.

Acesso em 30 jul. 2011.

FREIRE, Rafael de Luna. Versão brasileira Contribuições para uma história da dublagem cinematográfica no Brasil nas décadas de 1930 e 1940. Ciberlegenda (UFF. Online), n.24, v. 1, p. 7-18, 2011.

PIPANO, Isaac. Além do que se vê - o som e as paisagens sonoras no documentário Dong, de Jia Zhang-ke. Ciberlegenda (UFF. Online), n.24, v. 1, p. 73 / 07-83, 2011.

VEDANA, Viviane. Diálogos sobre a imagem visual e a imagem sonora: a experiência de escritura do sonoro nos documentários etnográficos. Ciberlegenda (UFF. Online), n.24, v. 1, p. 29-42, 2011.

VENANCIO, Rafael D. O.. Efeitos sonoros enquanto fala audiovisual: Análise de Gerald McBoing-Boing à luz do $\$ 528$ das Investigações Filosóficas. Ciberlegenda (UFF. Online), n.24, v. 1, p. 126-137, 2011.

\section{Revista Universitária do Audiovisual (RUA)}

BOZICANIN, José Eduardo. As idéias da trilha sonora do filme Akira. RUA - Revista Universitária do Audiovisual, v. 4, p. 12, 2008. <http://www.ufscar.br/rua/site/?p=163>. Acesso em 30 jul. 2011.

LEME, Gerson Rios . Escutando o Cinema. RUA - Revista Univesitária do Audiovisual, v. 02, p. 145, 2008. <http://www.ufscar.br/rua/site/?p=145>. Acesso em 30 jul. 2011. 
PEREIRA, Kira Santos. Candinho: a construção do espaço narrativo através da relação imagem-som. RUA - Revista Universitária Audiovisual. São Carlos, 2009a. Disponível em: $<$ http://www.ufscar.br/rua/site/?p=1619>. Acesso em 30 jul. 2011.

, Kira Santos. Se Podes Ouvir, Escuta: relações audiovisuais do filme Ensaio Sobre a Cegueira e considerações sobre seu processo criativo. RUA - Revista Universitária do Audiovisual, p. 1-2, 2009b. Disponível em: $<$ http://www.rua.ufscar.br/site/?p=1680>. Acesso em 30 jul. 2011.

TORRES, Alfredo Werney Lima. A Sinfonia dos Pássaros. RUA - Revista Universitária do Audiovisual. São Carlos, 2009. Disponível em: <http://www.ufscar.br/rua/site/? p=2194\#_ftn1>. Acesso em 30 jul. 2011.

\section{Revista CONTEMPORÂNEA}

CASTANHEIRA, José Cláudio Siqueira. A Paisagem Sonora Eletrônica: a reconstrução do mundo sonoro contemporâneo no cinema. Contemporânea: revista de Comunicação e Cultura. Rio de Janeiro, vol. 06, 2008 a.

, José Cláudio Siqueira. Electronic Tonalities: o espaço eletrônico e a impressão de realidade na ficção científica. Contemporânea: revista de Comunicação e Cultura. Rio de Janeiro, vol. 11, 2008b.

, José Cláudio Siqueira. A Presença do Som: proposta para uma investigação material da experiência sonora no cinema. Contemporânea: revista de Comunicação e Cultura. Rio de Janeiro, vol. 07, n 06, 2009b.

, José Cláudio Siqueira. O som eletrônico no cinema: uma abordagem fenomenológica. Contemporânea: revista de Comunicação e Cultura. Ed 15: Rio de Janeiro, vol. 8, n2, $2010 \mathrm{~b}$.

\section{Revista TEOREMA}

MENDES, Eduardo Santos. Pensando a Relação Imagem-Som. TEOREMA - Crítica de Cinema, Porto Alegre, v. 5, p. 51-55, 2004.

Eduardo Santos; PINTO, Ivonete. Lucrecia Martel e o benefício da incerteza. TEOREMA - Crítica de Cinema, Porto Alegre, v. 8, 2005.

\section{$\underline{\text { Revista NAU }}$}

SILVA, Márcia Regina Carvalho da. De olhos e ouvidos bem abertos: uma classificação dos sons no cinema. Revista NAU - Revista de Comunicação Audiovisual da Intercom, São Paulo, v.1, n.2, p.199-216, ago/dez 2008. 


\section{$\underline{\text { Revista E-Compós }}$}

CARREIRO, Rodrigo. Relações entre imagens e sons no filme Cinema, Aspirinas e Urubus. Revista da Associação Nacional dos Programas de Pós-Graduação em Comunicação Ecompós, Brasília, v.13, nº 1, $2010 \mathrm{~b}$.

\section{Revista SONORA}

PEDREIRAS, Aline Riera. O som surround e suas formas de uso. Revista Sonora, vol. 1 (1), UNICAMP, 2008.

\section{$\underline{\text { Ecos Revista }}$}

COSTA, Fernando Morais da. Que papel é delegado ao som, em um meio audiovisual? A imagem preponderante, e a inserção do som no cinema. Ecos Revista, Pelotas - RS, v. 7, n. 1, p. 71-91, 2003e.

\section{$\underline{\text { Revista ArtCultura }}$}

Carrasco, Claudiney. O Sonho de Edison: o advento do som sincronizado. ArtCultura (UFU), v. 5, n. 6, p. 53-65. Uberlândia, 2003.

\section{Revista Gragoatá}

COSTA, Fernando Morais da. Se pouco se diz sobre o som, quem fala sobre o silêncio nos filmes?. Gragoatá Revista do Programa de Pós-Graduação em Letras UFF, Niterói, v. 16, p. 105-116, 2004b.

\section{$\underline{\text { Revista Significação }}$}

MENDES, Eduardo Santos. Walter Murch: a revolução da trilha sonora cinematográfica (187/224). In: Significação nº 26. São Paulo: Annablume, 2006.

\section{Revista UNIMONTES Científica}

DOPPENSCHMITT, Elen. Voz e Canto Popular do Negro no Cinema - poética cinematográfica no documentário Adão ou Somos Todos Filhos da Terra de Walter Salles e Daniela Thomas. UNIMONTES Científica, v. 8, p. 41-50, $2007 \mathrm{~b}$.

\section{$\underline{\text { Revista CULT }}$}


MENDES, Eduardo Santos; CARRASCO, Claudiney. A relação imagem/som nos filmes de Kubrick. Revista Cult, São Paulo, p. 55 - 59, 01 out. 2007.

\section{$\underline{\text { Revista Caligrama }}$}

SILVA, Márcia Regina Carvalho da. A Trilha Sonora do Cinema: proposta para um "ouvir" analítico. Caligrama: Revista de Estudos e Pesquisa em Linguagem e Mídia. São Paulo, vol. 03, no 01, 2007.

\section{$\underline{\text { Revista DEVIRES }}$}

DÖPPENSCHMITT, Elen. Por uma Política da Voz: Tomás Gutiérrez Alea e as Memórias do Subdesenvolvimento. Devires (UFMG), v. 5, p. 184-203, 2008.

\section{$\underline{\text { Revista Sessões do Imaginário }}$}

HAUSSEN, Luciana. Som, Câmera, Ação: a relevância do som na história do cinema. Sessões do Imaginário (Impresso), v. 20, p. 17-22. Porto Alegre, 2008.

\section{Revista Entre. $\underline{\text { Meios }}$}

CASTANHEIRA, José Cláudio Siqueira. Pré-escutas: modelos de audibilidades dos primeiros cinemas. Entre.Meios, v. 6, 2009a.

\section{Revista Distúrbios da Comunicação}

AMARAL, Vitoria Rocha Prado; FERREIRA, Leslie Piccolotto; SOUZA, Priscila Haydée. A Fonoaudiologia e o ator de cinema: relatos de profissionais do meio cinematográfico. Distúrbios da Comunicação, v. 22, p. 133-147, 2010 a.

\section{$\underline{\text { Revista Galáxia }}$}

AMARAL, Vitoria Rocha Prado; FERREIRA, Léslie Piccolotto; MARTZ, Maria Laura Wey; SOUZA, Priscila Haydée. Representações de Voz e Fala no Cinema. Galáxia, v. 10, p. 151$164,2010 \mathrm{~b}$.

\section{Revista LOGOS: Comunicação \& Universidade}

COSTA, Fernando Morais da. Pode o cinema contemporâneo representar o ambiente sonoro em que vivemos? Logos: Comunicação \& Universidade. Rio de Janeiro, vol. 17, $\mathrm{n}^{\circ} 32$, 2010 b. 


\section{$\underline{\text { Revista CoMtempo }}$}

ALMEIDA, Natasha Hernandez. O artista silencioso: um estudo da construção sonora no filme do Cineclube Universitário de Campinas. CoMtempo (Revista Eletrônica do Programa de Pós-Graduação em Comunicação da Faculdade Cásper Líbero), vol. 2, n2, ano 3. São Paulo, dez. 2011.

\section{$\underline{\text { Revista Cinema Caipira }}$}

ALVES, Bernardo Marquez. Produção Sonora no Cinema Contemporâneo: um olhar sobre desafios do som no cinema brasileiro e o processo de finalização de som do filme "Tropa de Elite 2". Revista Cinema Caipira, n 31. Rio Claro, set. 2011.

\section{Revista Estudos da Comunicação}

CASTANHEIRA, José Cláudio Siqueira. O som expandido: os novos espaços do som no cinema. Revista de Estudos da Comunicação, v. 12, p. 265-273, 2011 b.

\section{$\underline{\text { Revista Filme Cultura }}$}

COSTA, Fernando Morais da. Como soa hoje experimental?. Filme Cultura, v. 54, p. 49-54, $2011 b$.

\section{Revista RUMORES}

CUNHA, Damyler Ferreira. A Submersão nas Imagens Sonoras: o som e suas dimensões reais e imaginárias. Revista Rumores. Ed. 9, vol 1, São Paulo, janeiro-junho de 2011.

\section{$\underline{\text { Revista ORSON }}$}

LEME, Gerson Rios. Pensando a trilha sonora para audiovisual. ORSON - Revista dos Cursos de Cinema do Cearte UFPEL, v. 1, p. 89-95, 2011

\section{$\underline{\text { Revista Mediação }}$}

RODRIGUES, Rodrigo Fonseca e. Sonoridades do cinema: Tarkovsky e a heterocronia da escuta. Mediação (Belo Horizonte), v. 13, p. 113-122, 2011.

\section{Coleção Cadernos de Pesquisa: O Novo Cinema Paulista}

GATTI, Andre Piero; MENDES, Eduardo Santos. A nova sonoridade do cinema em São Paulo. In: André Piero Gatti. (Org.). Coleção Cadernos de Pesquisa: O Novo Cinema Paulista. 1 ed. São Paulo: Centro Cultural São Paulo, 2008, v. 05, p. 43-64. 


\section{$\underline{\text { Portal Mnemocine }}$}

COSTA, Fernando Morais da. Primeiras tentativas de sonorização no cinema brasileiro (os cinematógrafos falantes 1902-1908). (versão integral). Mnemocine, 2006. Disponível em: $<\mathrm{http}$ ://www.mnemocine.com.br/index.php/cinema-categoria/25-historia-no-cinema-historiado-cinema/121-primeiras-tentativas-de-sonorizacao-no-cinema-brasileiro-os-cinematografosfalantes-1902-1908>. Acesso em 07 de jul. 2012. 


\section{ANEXO VII:}

Lista extra com materiais levantados mas que não se encaixaram no foco principal da pesquisa.

\section{ESTUDOS DA TRILHA MUSICAL}

\section{Livros:}

BERCHMANS, Tony. A Música do Filme: tudo o que você gostaria de saber sobre a música de cinema. São Paulo: Escrituras Editora, 2006.

CARRASCO, Claudiney Rodrigues. Sygkhronos: A formação da poética musical do cinema. São Paulo: Via Lettera: FAPESP, 2003.

FREIRE, Rafael de Luna (org.). Nas trilhas do cinema brasileiro. Rio de Janeiro: Tela Brasilis: CineMúsica: Light, 2009.

GUERRINI, Irineu Junior. A Música no Cinema Brasileiro: os inovadores anos sessenta. São Paulo: Terceira Margem, 2009.

MÁXIMO, João. A Música do Cinema: os 100 primeiros anos. Rio de Janeiro: Rocco, 2003. V1 e 2.

TINHORÃO, José Ramos. Música Popular. Teatro e Cinema. Petrópolis. Vozes, 1972

\section{Teses:}

EIKMEIER, Martin. Remo Usai: o nacional e o estrangeiro na música do cinema brasileiro. Tese (Doutorado em Multimeios). UNICAMP. Campinas, 2010.

GUERRINI, Irineu Junior. A Música no Cinema Brasileiro dos Anos Sessenta: inovação e diálogo. Tese (Doutorado em Ciências da Comunicação) USP. São Paulo 2002.

JESUS, Guilherme Maia de. Elementos para uma poética da música do cinema: ferramentas conceituais e metodológicas aplicadas na análise da música dos filmes Ajuste Final e $O$ homem que não estava lá. Tese (Doutorado em Comunicação e Cultura Comtemporânea). UFBA. Salvador, 2007.

LÓPEZ, Bernardo Enrique Rozo. Por uma escuta cinematográfica: etnomusicologia das mediações sonoro-musicais do filme brasileiro "Tropa de Elite". UFBA, 2010.

MACIEL, Katia Augusta. Film, Popular Music and Television: Intertextuality in Brazilian Cinema. Tese (Doutorado em Film Studies). University of Southampton. Southampton, 2008.

MIRANDA, Suzana Reck. Filmando a Música: uma interpretação do cinema de François Girard. Tese (Doutorado em Multimeios). UNICAMP. Campinas, 2006. 
PEREIRA, Márcio da Silva. O leitmotiv: da ópera, ao cinema, à televisão. Tese (Doutorado em Música) UNIRIO, 2007.

VIDIGAL, Leonardo Alvares. "A Jamaica é aqui": arranjos audiovisuais de territórios musicados. Tese (Doutorado em Comunicação Social) UFMG. Belo Horizonte, 2008.

\section{Dissertações:}

AGUIAR, Wislaine Nogueira de. Música como Personagem e como Trilha Sonora em Meio Audiovisual: um estudo de relações interartísticas entre as suítes para violoncelo solo de J.S. Bach e os filmes Sarbanda e Seis Gestos. Dissertação (Mestrado em Música). UFG. Goiânia, 2007.

ALMEIDA, Gabriela Machado Ramos de Almeida. O Cinema Punk: um estudo sobre documentários de Rock e estratégias de produção de efeitos do filme $O$ lixo e a fúria. Dissertação (Mestrado em Comunicação e Cultura Contemporânea) UFBA. Salvador, 2009.

BAPTISTA, André. Funções da Música no Cinema: contribuições para a elaboração de estratégias composicionais. Dissertação (Mestrado em Música). UFMG. Belo Horizonte, 2007.

BELLEBONI, Luciene. Com Paixão: as relações entre o som e a imagem no audiovisual contemporâneo. (Mestrado em Comunicação). USP. São Paulo, 2004.

BONETTI, Mariângela Coelho Jacomini. Manguebeat e árido-movie: o som em baile perfumado. Dissertação (Mestre em Comunicação e Semiótica). PUC. São Paulo, 2003.

CARVALHO, Francisco Egydio. O Cinema como Experiência Sinfônica: a partitura orquestral do filme O Iluminado, de Stanley Kubrick. Dissertação (Mestrado em Multimeios) UNICAMP. Campinas, 2010.

CHITARO, Gustavo Rocha. Metropolis: o uso do jazz no cinema de animação japonês. Dissertação (Mestrado em Música) UNICAMP. Campinas, 2009.

COSTA, Fábio Freire da. Poética do Pop: a música como recurso narrativo no cinema contemporâneo. Dissertação (Mestrado em Comunicação e Cultura Contemporânea). UFBA. Salvador, 2007.

CUNHA, Paulo Roberto Ferreira da. O Cinema Musical Norte-Americano nos Anos 1980: análise de traços estéticos, temáticos e mercadológicos através dos filmes Fama e Flashdance. Dissertação (Mestrado em Comunicação). UAM. São Paulo, 2009.

EIKMEIER, Martin. Trilha Sonora: a música como elemento de sintaxe do discurso narrativo no cinema. Dissertação (Mestrado em Multimeios). UNICAMP. Campinas, 2004.

FERREIRA, Sandra Cristina Novais Ciocci. Assim era a música da Atlantida: a trilha musical do cinema popular brasileiro no exemplo da Companhia Atlantida Cinematográfica 1942/1962. Dissertação (Mestrado em Música). UNICAMP. Campinas, 2010. 
GARCIA, Demian Albuquerque. A questão da música original através da historia do cinema brasileiro. Dissertação (Mestrado em Cinema e Audiovisual). Université de Paris III. Paris, 2009.

GORINI, Décio. Trilhas do Sertão: música e imagem na representação do sertão no cinema brasileiro recente. Dissertação. UNB. Brasília, 2004.

HICKMANN, Felipe Copetti. Música, Cinema e Tempo Narrativo: uma abordagem analítica dos problemas de continuidade. Dissertação (Mestrado em Música). UFPR. Curitiba, 2008 .

MAGAlHÃES, Michelle Agnes. Futurismo e Música na trilha sonora de Dziga Vertov. Dissertação (Mestrado em Música). UNICAMP. Campinas, 2005.

MARTUCCI, Maurício Dotto. Dialogismo e tradução intersemiótica em Pink Floyd The Wall: luto e melancolia na Inglaterra do pós-guerra. Dissertação (Mestrado). UFSCAR, 2010.

MAUAD, Paulo Augusto Di Giorgio. A composição de música para filme de animação: um estudo de caso. Dissertação. UFRJ. Rio de Janeiro, 2002.

ONOFRE, Cintia Campolina de. O zoom nas trilhas da Vera Cruz. Dissertação (Mestrado em Música). UNICAMP. Campinas, 2005.

PEREIRA, Carlos Eduardo. A música no cinema sonoro brasileiro da década de 1930, nacionalismo, música popular e identidade cultural. Dissertação (Mestrado em Música). UFRJ. Rio de Janeiro, 2008.

PEREIRA, Márcio da Silva. Assalto ao Trem Pagador: análise de uma estrutura audiovisual. Dissertação (Mestrado em Música). UNIRIO. Rio de Janeiro, 2002.

PEREIRA, Miguel Serpa. Cinema e Ópera: Um Encontro Estético em Wagner. Dissertação (Mestrado em Artes), ECA-USP, São Paulo, 1995.

QUINTANA, Fabiana. Orfeu: do mito à realidade brasileira - uma análise da trilha sonora dos filmes "Orfeu negro" (1959) e "Orfeu" (1999) baseados na peça "Orfeu da Conceição" de Vinícius de Moraes. Dissetação (Mestrado em Multimeios) UNICAMP. Campinas, 2011.

SALLES, Filipe Mattos de. Imagens Musicais ou Música Visual - Um estudo sobre a afinidade entre o som e a imagem baseado no filme 'Fantasia'(1940) de Walt Disney. Dissertação (Mestrado em Multimeios). PUC-SP. São Paulo, 2002.

SANTOS, Ana Cecília dos. Composição musical: estudos dirigidos para audiovisual. Dissertação (Mestrado em Letras). UFMT. Cuiabá, 2008.

SOUZA, Christine Veras de. O Show Deve Continuar: o gênero musical no cinema. Dissertação (Mestrado em Artes Visuais). UFMG. Belo Horizonte, 2005

VASCONCELOS. André Luiz Olzon. A influência da trilha sonora sobre a percepção da obra cinematográfica: A análise filmica de Bye bye Brasil, Pra frente Brasil e Central do Brasil. Dissertação (Mestrado em Música). UNICAMP. Campinas, 2008. 


\section{Artigos:}

BAPTISTA, André; FREIRE, Sérgio. As funções da música no cinema segundo Gorbman, Wingstedt e Cook: novos elementos para a composição musical aplicada. XVI Congresso da ANPPOM. Brasília, 2006.

BARRENHA, Natalia C.; BUENO, M. P. B.; FONTOURA, L. G.; MASSON, Erica; REGIS, Douglas; TÁPIA, Daniel. A música na imagem, a imagem na música: Análise do musical em animação "O estranho mundo de Jack". Ensaio Magazine, p. 14 - 18, 01 set. 2009.

BELLEBONI, Luciene. Algumas relações entre as imagens e os sons no audiovisual contemporâneo: o crepúsculo de uma era. In: Anais do Congresso brasileiro de ciências da comunicação - INTERCOM. Porto Alegre, 2004

BRÄUTIGAM, Alexandre Baliú. Música eletroacústica, cinema e literatura: convergências em análise audiovisual. XVI Congresso da Associação Nacional de Pesquisa e Pósgraduação em Música (ANPPOM). Brasília, 2006.

, Alexandre Baliú. Sons Tonicos e Complexos: Artemiev e Tarkovski em "Stalker". XV Congresso da Associação Nacional de Pesquisa e Pós-graduação em Música (ANPPOM). Rio de Janeiro, 2005.

CARRASCO, Claudiney Rodrigues. A Infância Muda: a música nos primórdios do cinema. Revista OuvirOUver. Uberlândia, vol. 01, nº 01, 2005.

, Claudiney . A Trilha Musical do filme Maria Antonieta: uma análise macroestrutural.

In: Anais do XX Congresso da ANPPOM, Florianópolis, 2010. v. 1. p. 722-726.

, Claudiney. A Música de O Nascimento de uma Nação I - Síntese e consolidação do Cinema Mudo. Cadernos de Pós-Graduação da UNICAMP, v. 5, n. 1, p. 51-56, 2001.

, Claudiney. A Música de O Nascimento de uma Nação II - A Ópera sem Libreto. Cadernos de Pós-Graduação da UNICAMP, v. 2, n. 2, p. 149-158, 2001. 1-4, 2010 .

Claudiney. Trilhas: o som e a música no cinema. ComCiência (UNICAMP), v. 116, p.

CIOCCI, Sandra C. N. ; CARRASCO, Claudiney. A Atlântida e seus sons. In: Musica de/para - $6^{\mathbf{0}}$ encontro de música e mídia, 2010, São Paulo. Música de/para, 2010.

, Sandra C. N. ; CARRASCO, Claudiney. De vento em popa o musical que apresentou a bossa nova ao público de cinema no Brasil. In: XIX Congresso ANPPOM. Curitiba, 2009.

, Sandra C. N. ; CARRASCO, Claudiney. Pesquisa em música aplicada à dramaturgia e

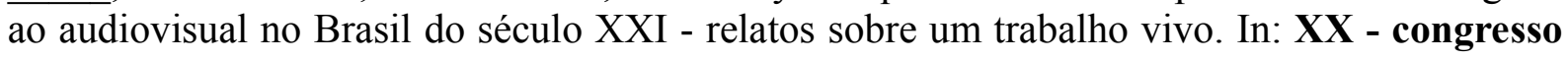
ANPPOM. Florianópolis, 2010.

COSTA, Fábio Freire da. Embalagem pop: uma análise da trilha sonora de Trainspotting. In: Anais do XXIX Congresso da INTERCOM. Brasília, 2006. 
COSTA, Fábio Ferreira da. Trilhas Sonoras: uma sinergia entre as indústrias cinematográficas e fonográfica. XI Estudos de Cinema e Audiovisual (SOCINE). São Paulo, vol. 10, 2010.

COSTA, Fernando Morais da. Início do Cinema Sonoro: a relação com a música popular no Brasil e em outros países. Estudos Socine de Cinema, Ano VII. São Paulo: Annablume, 2006.

, Fernando Morais da. John Williams - Perceber ou não a música de cinema. Rio de Janeiro: OSB - Orquestra Sinfônica Brasileira, 2010 (OSB - Orquestra Sinfônica Brasileira - Programação Maio 2010).

, Fernando Morais da. Os estudos do som no cinema, da música e a lembrança dos músicos. Revista do Festival Internacional de Cinema de Arquivo Arquivo Nacional, v. 7, p. 54-59. Rio de Janeiro, 2010.

, Fernando Morais da. Música popular no cinema da América Latina. Cinemais, Rio de Janeiro, v. 38, p. 225-238, 2005.

FERNANDES, G. F.; ROCHA, E. S. E.; ANJOS, F. W. dos. Paisagens Sonoras em cidade cinemáticas. In: XVII congresso da ANPPOM, 2007, São Paulo.

FERREIRA, S. C. N. C.; CARRASCO, Claudiney. De vento em popa o musical que apresentou a bossa nova ao público de cinema no Brasil. In: Anais do XIX Congresso da ANPPOM. Curitiba, 2009. p. 403-408.

FRANCO, César H. R.; CARRASCO, Claudiney. Análise da trilha musical do filme "Touts les Matins du Monde" de Alain Corneau. In: Anais XVII Congresso da ANPPOM XVII Congresso. São Paulo, 2007.

GUERRINI, Irineu Junior. Apontamentos para um estudo da música nos filmes de Humberto Mauro. RECINE - Revista do Festival Internacional de Cinema de Arquivo, Rio de Janeiro, p. 40 - 45, 10 out. 2010.

, Irineu Junior. "Picnic": música e articulação audiovisual. FACOM. Revista de Comunicação da FAAP, v. 9, p. 32-37, 2001.

HENKIN, Leo. As trilhas do cinema TEOREMA - CRíTICA DE CINEMA, PORTO ALEGRE, v. 5, p. 56-58, 2004.

HICKMANN, F. C. Música e Organização do Tempo Narrativo em Irreversível. Revista Universitária do Audiovisual (UFSCAR), v. 00, p. 1-2, 2008.

JESUS, Guilherme Maia de. A Música Extradiegética no Cinema Comercial Brasileiro Contemporâneo: um estudo sobre as funções da música nos filmes brasileiros indicados ao Oscar nos anos 90. UNIRIO. Rio de Janeiro, 2002.

, Guilherme Maia. Alguns Aspectos da Música no Cinema Moderno Brasileiro. CineCachoeira - Revista de Cinema da UFRB, Cachoeira, BA, 2010. 
JESUS, Guilherme Maia de. A Música de O Quatrilho. Uma comparação entre as estratégias de uso de música no cinema clássico e na produção cinematográfica brasileira contemporânea. XIII Encontro Nacional da ANPPOM. Belo Horizonte, 2001.

, Guilherme Maia de. Do "lixo" ao luxo: um ensaio sobre a música de pós-produção nos almodramas. Contemporanea, Salvador, vol. 8, nº 2, 2010.

, Guilherme Maia de. Orfeu e Orfeu. A música nas favelas de Marcel Camus e de Cacá Diegues. ArtCultura (UFU), v. N.10, p. 95-109, 2005.

LEME, Gerson Rios. Dos desafios e prazeres de fazer música para filme. Rascunho, Santa Maria, p. 10 - 10, 13 jul. 2005.

LOVISI, Daniel Menezes. Radamés Gnattali e a trilha musical no cinema brasileiro. I Simpósio Brasileiro de Pós-Graduandos em Música. Rio de Janeiro, 2010.

MACIEL, K. A. Mediações culturais no filme Invasor: Interseções entre a música e o cinema. Contracampo (UFF), v. 21, p. 217-230, 2010.

, K. A. Interconexões entre filme, música popular e televisão no cinema brasileiro. In: Ciclo de conferências cinema brasileiro: Desafios culturais e econômicos.São Paulo: SESC / SP, 2008. v. 1.

MAGAlHÃES, M. A.; CARRASCO, Claudiney. A sonoridade futurista do filme "Entusiasmo, sinfonia do Donbass" de Dziga Vertov. Cadernos de Pós-Graduação da UNICAMP, v. 8, p. 219-224, 2007.

MANCINI, O. M. M.; CARRASCO, Claudiney. A Forma da Música de Cinema. V SIMCAM - V Simpósio Internacional de Cognição e Artes Musicais. v. 1. p. 303-309. Goiânia, 2009.

, O. M. M.; CARRASCO, Claudiney. A organização temática da trilha sonora musical de Era Uma Vez na América. In: XIX Congresso da ANPPOM, 2009, Curitiba. Anais do XIX Congresso da ANPPOM, 2009. p. 778-781.

, O. M. M.; CARRASCO, Claudiney. Ennio Morricone: A Música Fala... Sem Palavras. In: XVIII Congresso da ANPPOM. Salvador : ANPPOM, 2008. v. 1.

, O. M. M.; CARRASCO, Claudiney. Ennio Morricone: O "Canone Inverso". XVII Congresso da ANPPOM. São Paulo: Anais do Congresso, 2007.

MARTINS, Fernanda Aguiar Carneiro. Paranoid Park: das composições de Nino Rota à música eletroacústica. XI Estudos de Cinema e Audiovisual (SOCINE). São Paulo, vol. 11, 2010 .

MELLO, Clélia . Música e Cinema: um pequeno texto antiformalista por uma estética do irracional. RUA. Revista Universitária do Audiovisual, v. 1, p. 125-135, 2008. Disponível em: $<$ http://www.ufscar.br/rua/site/?p=131>. 
MIRANDA, Suzana Reck. A liberdade e a duplicidade da música em kieslowski. RUA Revista Universitária do Audiovisual, p. 1-2, 2008. Disponível em:

$<$ http://www.ufscar.br/rua/site/?p=122>.

, Suzana Reck. A Música de Zbigniew Preisner e o Universo Ficcional de Krzysztof Kieslowski. Idéias e Argumentos Revista de Divulgação Científica do Centro Unisal, Americana SP, v. 4, 2001.

, Suzana Reck. Bernard Herrmann, compositor-autor?. Cadernos de Pós-Graduação da UNICAMP, Campinas SP Brasil, v. 6, n. 2, p. 136-143, 2002.

, Suzana Reck. Escutar um Filme: Variações de uma mesma Música. XIII Encontro Nacional da ANPPOM. Belo Horizonte, 2001.

, Suzana Reck. Filmando a Música: as variações de escuta no filme de François Girard. Estudos Socine de Cinema, Ano VII. São Paulo: Annablume, 2006.

, Suzana Reck. Film as music: O rádio musical de Glenn Gould e a construção sonora do filme de François Girard. XIV Encontro Nacional da ANPPOM. Porto Alegre, 2003.

Suzana Reck. O Rádio Musical de Glenn Gould e a Construção Sonora do filme de François Girard. XXVII CONGRESSO BRASILEIRO DE CIÊNCIAS DA COMUNICAÇÃO (INTERCOM). Porto Alegre RS, 2004.

MONZANI, Josette Monzani. As voltas e às voltas de sons e imagens em Por volta da meianoite. RUA - Revista Universitária do Audiovisual. São Carlos, 2008. Disponível em: $<$ http://www.ufscar.br/rua/site/?p=153>.

MORETTIN, Eduardo V.. Cine, música e historia: Heitor Villa-Lobos y O Descobrimento do Brasil (1937) de Humberto Mauro. Archivos de la Filmoteca, Valencia, n. 41, p. 70-83, 2002.

, Eduardo V.. Sonoridades do cinema dito silencioso: filmes cantantes, história e música. Significação (UTP), v. 1, no 31, p. 149-163, 2009.

ONOFRE, C. C. de. A ênfase a ação filmada por meio de construções musicais nos filmes da Vera Cruz.. Cadernos de Pós-Graduação da UNICAMP, v. 03, p. 31-42, 2006.

, C. C. O zoom nos documentos musicais da Companhia Cinematográfica Vera Cruz. História Social (UNICAMP), v. 11, p. 261-266, 2005.

, C. C. de; CARRASCO, Claudiney. A música no cinema brasileiro em 1981 e 2010: análise das trilhas musicais dos filmes. In: Anais do XX Congresso da ANPPOM, Florianópolis, 2010. v. 1. p. 1-6.

, C. C. de; CARRASCO, Claudiney. A obra de Francisco Mignone no cinema brasileiro: análise das músicas compostas para os filmes da Cia. Vera Cruz. In: XVII Congresso da ANPPOM, 2007, São Paulo. Anais - ANPPOM XVII Congresso, 2007.

PEREIRA, Miguel. Da ópera wagneriana à estética cinematográfica: aproximações possíveis. Revista ALCEU. Rio de Janeiro, vol. 09, nº 17, 2008. 
PICCINI, Alexandre. Entre a Música e o Cinema Michael Nyman e Peter Greenaway. RUA. Revista Universitária do Audiovisual, v. 1, p. 125-135, 2008. Disponível em: $<$ http://www.ufscar.br/rua/site/?p=125>.

PIRES, Betânia Levien ; BÜNDCHEN, Denise Sant'anna. Um delineamento analítico da trilha sonora do filme Cinema Paradiso. In: XVI Congresso da ANPPOM, 2003, Porto Alegre. Anais do XVI Congresso da ANPPOM, 2003.

QUINTANA, Fabiana; CARRASCO, Ney. Na trilha de Orfeu Negro. A representação da imagem sonora e cultural brasileira no final dos anos 50. In: I Jornada de Estudos de Cinema e Fotografia do Programa de Pós-Graduação em Multimeios. Campinas, 2010. v. 1.p. 1-14.

RIBEIRO, Eric. Música, Cinema e toda confusão que se pode imaginar. RUA - Revista Universitária do Audiovisual, v. 1, p. 125-135, 2008. Disponível em: $<$ http://www.ufscar.br/rua/site/?p=135>.

SALLES, Filipe Mattos de. A Natureza na Arte: a Simbiose do Som e da Imagem. XXXI Congresso Brasileiro de Ciências da Comunicação (INTERCOM). Natal, 2008.

, Filipe Mattos de. A Origem da Trilha Sonora. Mnemocine, v. 1, p. 9, 2008.

SANTANA, G. C. C. S.; NOGUEIRA, L. M. Comunicação, Cinema e Música: o personagem invisível em Durval Discos. INTERCOM. XII Congresso de Ciências da Comunicação na Região Centro - Oeste - Goiânia - GO 27 a 29 de maio de 2010.

G. C. C. S. ; NOGUEIRA, Lisandro Magalhães. Música, cinema e o limite da sanidade: análise da canção na trilha sonora do filme Bicho de Sete Cabeças, de Laís Bodanzky. In: II Seminário Mídia e Cultura (Facomb/UFG), 2010, Goiânia-GO. Anais do II Seminário Mídia e Cultura, 2010.

SILVA, Edison Delmiro. A modernidade por trás do pano: o advento dos 'filmes cantantes' no Brasil. Revista Ceciliana (Santos), 2007.

SILVA, Márcia Regina Carvalho da. A Música no Cinema Brasileiro. XXXIII Congresso Brasileiro de Ciências da Comunicação (INTERCOM). Caxias do Sul, 2010.

, Márcia Regina Carvalho da. A Música no Cinema Industrial dos Anos 90. Revista AV - Audiovisual. São Leopoldo, vol. 03, nº 06, 2005.

, Márcia Regina Carvalho da. Coisas da roça: a música sertaneja no cinema brasileiro.

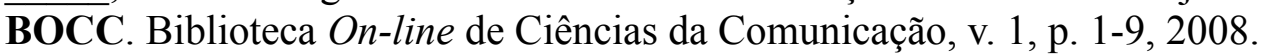

VERAS, Christine. O Gênero Musical Reinventado. XXX Congresso Brasileiro de Ciências da Comunicação (INTERCOM), Santos, 29 de agosto a 02 de setembro de 2007. 
VIEIRA, João Luiz. Música, dança e performance: o corpo em movimento. Associação Cultural Tela Brasilis. (Org.). O Som no Cinema. 1 ed. Rio de Janeiro: Associação Cultural Tela Brasilis, 2008.

VIDIGAL, Leonardo A.. "A Jamaica é aqui": relações entre música e território no audiovisual. Revista Brasileira do Caribe (Impresso), v. IX, p. 425-484, 2009.

, Leonardo A.. Algumas considerações sobre a música nos filmes de Jean Rouch. Devires (UFMG), v. 6, p. 46-61, 2009.

\section{ESTUDOS DA CANCC̃̃O}

Teses:

SILVA, Márcia Regina Carvalho da. A canção popular na história do cinema brasileiro. Tese (Doutorado em Multimeios). UNICAMP. Campinas, 2009.

SILVA, Edison Delmiro. O papel narrativo da canção nos filmes brasileiros a partir da Retomada. Tese (Doutorado em Comunicação e Semiótica). PUC. São Paulo, 2008.

\section{Dissertações:}

CAMARNEIRO, Fabio Diaz. Contradições da canção: música popular brasileira em "O Mandarim", de Julio Bressane. Dissertação (Mestrado em Ciências da Comunicação). USP. São Paulo, 2009.

\section{Artigos:}

ALMEIDA, Gabriela Ramos de. De O Cantor de Jazz a Easy Rider: a canção popular no cinema nas décadas de 1920 a 1960. XXXIII Congresso Brasileiro de Ciências da Comunicação - Caxias do Sul, RS - 2 a 6 de setembro de 2010.

COSTA, Fábio Freire da . Violência pop e surf music: gêneros musicais e canções do passado como elementos narrativos em Pulp Fiction. In: Anais IX Congresso de Ciências da Comunicação na Região Nordeste (INTERCOM). Salvador, 2007.

FREIRE, Rafael de Luna. O silêncio (ou as canções) que precede(m) o esporro. In: Cinemais. Rio de Janeiro: Aeroplano, n. 38, 2005.

JESUS, Guilherme Maia de. A voz da mulher que chora (em algum lugar do passado): as canções dos filmes de Almodóvar. Repertório Teatro \& Dança, v. 11, p. 13-19, 2009.

SANTANA, G. C. C. S.; NOGUEIRA, Lisandro Magalhães. A canção popular brasileira no cinema nacional contemporâneo. In: Anais do $\mathbf{V}$ Seminário Intermestrandos em Comunicação (ESPM). São Paulo, 2010. 
SANTANA, G. C. C. S.; NOGUEIRA, Lisandro Magalhães. Cansaço e não pertença: a importância da canção na trilha sonora do filme Terra Estrangeira, de Walter Salles. In: Anais do X Congresso de ALAIC - Asociación Latinoamericana de Investigadores de la Comunicación. Bogotá-Colômbia, 2010.

SCHVARZMAN, Sheila. Cultura popular massiva no Brasil: o lugar do cinema sonoro e sua relação com a música popular. Revista Î́cone. Recife, vol.10, no 1, 2008.

SILVA, Márcia Regina Carvalho da. A canção no cinema brasileiro dos anos 80. XI Estudos de Cinema e Audiovisual (SOCINE). São Paulo, vol. 11, 2010.

, Márcia Regina Carvalho da. A Canção popular na História do Cinema Brasileiro. XVII Congresso da Associação Nacional de Pesquisa e Pós-graduação em Música (ANPPOM). São Paulo, 2007.

, Márcia Regina Carvalho da. A canção popular no cinema brasileiro: os filmes cantantes, as comédias musicais e as aventuras industriais da Cinédia, Atlântida e Vera Cruz. Revista Universitária do Audiovisual, p. 01-03, 2008.

, Márcia Regina Carvalho da. As canções do mangue-beat (bit) nas trilhas do cinema: Dois tempos. XXI Congresso Brasileiro de Ciências da Comunicação, Brasília, 6 a 9 de setembro de 2006 .

VASCONCELOS, A. L. O. . Cacá Diegues: A canção como convenção poética da narrativaAnálise da trilha sonora de Bye bye Brasil. In: XVII Congresso da ANPPOM - Associação Nacional de Pesquisa e Pós-graduação, São Paulo, 2007.

\section{OUTROS}

Livros:

FERREIRA, Daniela Carvalho M.; PAIVA, José Eduardo. O Áudio na Internet. Uberlândia: Edibras, 2008

MOTTA, Lívia Maria V. de M.; FILHO, Paulo Romeu (org.). Audiodescrição: transformando imagens em palavras. Câmara Brasileira do Livro: São Paulo, 2010.

RIGHNI, Rafael Roso. A Trilha Sonora da Telenovela Brasileira: da criação à finalização. São Paulo; Ed. Paulinas, 2004.

SÁ, Simone Pereira de (org.). Rumos da cultura da música: negócios, estéticas, linguagens e audibilidades. Porto Alegre: Sulina, 2010.

Teses:

CAPELLER, Ivan. O Cinema e Seu Duplo. Tese (Mestrado em Comunicação). UFF. Rio de Janeiro, 2010. 
MENDES, Eduardo Simões dos Santos. Walter Murch: A Revolução no Pensamento Sonoro Cinematográfico. Tese (Doutorado em Artes) USP. São Paulo, 2000. V

FERREIRA, Daniela Carvalho Monteiro. O Planejamento de Conteúdo Audiovisual para Websites: investigação sobre hibridísmo com elementos sonoros. Tese (Doutorado em Multimeios). UNICAMP. Campinas, 2010.

RIGHNI, Rafael Roso. A Trilha Sonora da Telenovela Brasileira: da criação à finalização. Tese (Doutorado em Ciências da Comunicação). USP. São Paulo, 2001.

SHUM, Lawrence Rocha. Topologia(s) Sonora(s) nos Games. Tese (Doutorado em Comunicação). PUC. São Paulo, 2008.

SOUZA, Luiz Otavio Carvalho Gonçalves de. A Música e os Efeitos Sonoros na Cena Teatral: reflexões sobre uma estética. Tese (Doutorado em Artes Cênicas). USP. São Paulo, 1999.

\section{Dissertações:}

BASTOS, Maiza de Lavenère. Language and Sound in Discourse: Characters, relationships and representations In the film Mulholland Drive. Dissertação (Mestrado em Letras) UFSC. Florianópolis, 2007.

FERREIRA, Daniela Carvalho Monteiro. O Som Internético: a ecolução, a situação e a estética sonora na internet. Dissertação (Mestrado em Multimeios). UNICAMP. Campinas, 2006.

GAMO, Alessandro Constantino. Aves sem rumo: a transitoriedade no cinema de Ozualdo Candeias. Dissertação (Mestrado em Multimeios), UNICAMP, Campinas-SP, 2000.

GAUDENZI, Ricardo Cutz. Arte Sonora: entre a plasticidade e a sonoridade. Um estudo de caso e pequena perspectiva histórica. Dissertação (Mestrado em Comunicação e Cultura). UFRJ, 2008.

OLIVEIRA, Gustavo Queiroz de. O Jogo Black Death: uma experiência de design sonoro e design de jogos de computadores. Dissertação (Mestrado em Multimeios). UNICAMP. Campinas, 2002.

SACIC, Rodrigo Maia. La Pratique du Son Dans le Nouveau Cinema Americain (19691980). Master 2 (Mestrado em Estética e História da Arte). Universite Paris III, Sorbonne. Paris, 2011.

SILVA, Eduardo Miranda. A voz do outro no cinema brasileiro contemporâneo: a questão da primeira pessoa. Dissertação (Mestrado em Comunicação Social). PUC. Rio de Janeiro, 2009.

SILVA, Lílian Campesato. Arte Sonora: uma metamorfose da musas. Dissertação (Mestrado em Música). USP. São Paulo, 2007. 
SOARES, Luiz Cláudio Cajaiba. Versão brasileira: dublagem na tv como recurso difusor do cinema. Dissertação (Mestrado). UFBA. Salvador, 1997.

VESPAR, Manuel Geraldo. Som \& Produção Musical para a Mídia. Dissertação (Mestrado em Comunicação). UFRJ. Rio de Janeiro, 2006.

\section{$\underline{\text { Artigos }}$}

ASPAHAN, Pedro Cardoso. Por uma pergunta sonora. In: LEONEL, J.; MENDONÇA, R. F. (Org.). Audiovisual Comunitário e Educaçãa: histórias, processos e produtos. Belo Horizonte: Autêntica Editora, 2010, v. 01, p. 125-143.

ALMEIDA, Lizandra de. Som Direto sempre relegado a segundo plano - desvalorizado, o trabalho dos técnicos do setor é imprescindível em quase metade das produções publicitárias. Mas os profissionais reclamam da falta de condições. Tela Viva, n.44, p. 22-23, jan. 1996.

ANDRADE, Leilane; BEHLAU, Mara; MESQUITA, Ingrid. A voz na dublagem de desenhos animados da Dream Works. Anais do V Colóquio Internacional "Educação e Contemporaneidade". São Cristovão, 2011.

ARAGÄO, Marisa Vieira de. Análise de som de O Bandido da Luz Vermelha. Cinematógrafos, n. 1, dez. 1983.

ARAÚJO, Luciana S. L. C. . A crítica de cinema, a chegada do som e o futuro do cinema. Olhar (UFSCar), v. 10/11, p. 261-267, 2008.

BALTAR, Mariana. A evidência do audível: o som documental e a tradição intervencionista no documentário brasileiro. Associação Cultural Tela Brasilis. (Org.). O Som no Cinema. 1 ed. Rio de Janeiro: Associação Cultural Tela Brasilis, 2008.

BARRENHA, Natalia Christofoletti. Crujidos, vueltas, rodeos: Uma análise da voz em O pântano. Asociación Argentina de Estudos de Cine y Audiovisual (AsAECA). Buenos Aires, 2010.

, Natalia Christofoletti. A estética sonora na obra de Lucrecia Martel. Asociación Argentina de Estudos de Cine y Audiovisual (AsAECA). Buenos Aires, 2010.

BERNARDET, Jean-Claude. A Entrevista. Associação Cultural Tela Brasilis. (Org.). O Som no Cinema. 1 ed. Rio de Janeiro: Associação Cultural Tela Brasilis, 2008.

CAESAR, Rodolfo. O tímpano é uma tela?. In: VI Forum do Centro de Linguagem Musical. São Paulo, 2004, v.1, p. 17-25.

CAPELLER, Ivan. Raios e Trovões: hiper-realismo e sound design no cinema contemporâneo. Associação Cultural Tela Brasilis. (Org.). O Som no Cinema. 1 ed. Rio de Janeiro: Associação Cultural Tela Brasilis, 2008.

COSTA, Fernando Morais da. A voz e o espelho. Rio de Janeiro: Jurubeba Produções, 2010 (Catálogo da mostra cinematográfica Cineastas e Imagens do Povo). 
COSTA, Fernando Morais da. As funções do som no cinema clássico narrativo. Associação Cultural Tela Brasilis. (Org.). O Som no Cinema. 1 ed. Rio de Janeiro: Associação Cultural Tela Brasilis, 2008.

, Fernando Morais da. Cinema mudo e passagem para o sonoro. Associação Cultural Tela Brasilis. (Org.). O Som no Cinema. 1 ed. Rio de Janeiro: Associação Cultural Tela Brasilis, 2008.

, Fernando Morais da. Há algo como um hiper-realismo sonoro no cinema argentino? Asociación Argentina de Estudos de Cine y Audiovisual (AsAECA). Buenos Aires, 2010.

, Fernando Morais da. O som das cidades, o céu de Lisboa. In: Anais do VI Lusocom Ciências da Comunicação em Congresso na Covilhã, 2004.

, Fernando Morais da. O som, desde o início do cinema. São Paulo: Centro Cultural do Banco do Brasil, 2007 (Texto de abertuta do Catálogo da mostra E o som se fez).

FLORES, Virginia. O Som no Cinema Brasileiro Contemporâneo. Associação Cultural Tela Brasilis. (Org.). O Som no Cinema. 1 ed. Rio de Janeiro: Associação Cultural Tela Brasilis, 2008.

FERREIRA, Léslie P. . Dubladores: uma voz para o personagem. In: Léslie Piccolotto Ferreira; Henrique Olival Costa. (Org.). Voz Ativa: falando sobre a clínica fonoaudiológica. São Paulo: Roca, 2001.

FREIRA, Rafael de Luna. Truste, Músicos e Vitrolas: a tentativa de monopólio da Western Electric na chegada do cinema sonoro no Brasil e seus desdobramentos. Imogofagia: Revista de la Asociación Argentina de Estudios de Cine y Audiovisual, n. 5, 2011.

GARCIA, Demian Albuquerque. Existe um 'som digital' no cinema?. Curitiba: Revista Científica / FAP, 2012.

LINS, Consuelo. O ensaio no documentário e a questão da narração em off. Associação Cultural Tela Brasilis. (Org.). O Som no Cinema. 1 ed. Rio de Janeiro: Associação Cultural Tela Brasilis, 2008.

LOBASSI, E. W. . Com o som morre o personagem Carlitos e nasce o ator Chaplin. RuaRevista Universitária do Audiovisual, v. 00, p. \#00, 2008. <http://www.ufscar.br/rua/site/? $\mathrm{p}=160>$

MACIEL, K. A. . Paisagem, música popular e o imaginário do sertão em filmes recentes. In: Caio Augusto Amorim Maciel. (Org.). Entre Geografia e Geosofia: Abordagens Culturais do Espaço. Recife: Editora Universitária/UFPE, 2009, v. , p. 215-230.

MANZANO, Luiz Adelmo Fernandes. Mixagem para Surround. Revista Produção Áudio, São Paulo, p. 30 - 32, 10 maio 2011.

, Luiz Adelmo Fernandes . Mixando com os Ouvidos. Revista Produção Áudio, São Paulo, 10 jul. 2010. 
MANZANO, Luiz Adelmo Fernandes . Back ups: passado, presente e futuro. Revista Produção Profissional - Brasil, São Paulo, 01 nov. 2008.

, Luiz Adelmo Fernandes . Mixagens para diferentes formatos. Revista Produção Profissional - Brasil, São Paulo, 22 ago. 2008.

, Luiz Adelmo Fernandes . Edição de som e mixagem: evolução na história do cinema brasileiro. Revista Produção Profissional, São Paulo, 08 nov. 2007.

, Luiz Adelmo Fernandes . Mudanças no panorama de áudio para cinema. Revista Produção Profissional, São Paulo, 01 nov. 2005.

MENDES, Eduardo Santos. Para uma reflexão em torno da análise do som cinematográfico. Balalaica: Revista Brasileira de Cinema e Cultura, São Paulo, v. 01, n.01, p. 79-83, 1997.

MENDES, Gilberta. Som direto: sua técnica. Filme Cultura, v. 1, n. 6, p. 54-55, set. 1967.

MIRANDA, Suzana Reck. Duas vozes para o som no cinema: Tati e Bresson. Associação Cultural Tela Brasilis. (Org.). O Som no Cinema. 1 ed. Rio de Janeiro: Associação Cultural Tela Brasilis, 2008.

NAGIB, Lúcia. A estética do silêncio. In: Cinemais. Rio de Janeiro, n.14, novembro/dezembro, 1998.

PALINKAS-SANCHES, Elaine et al. Análise vocal de personagens suicidas de filmes de cinema. Rev. Bras. Psiquiatr. [online]. 2010, vol.32, n.4, pp. 409-415. Epub. June 25, 2010.

PEREIRA, Carlos Eduardo. A Música no cinema silencioso no Brasil. Rio de Janeiro: Centro Cultural do Banco do Brasil, 2001 (Catálogo).

PEREIRA, Vinícius A.; CASTANHEIRA, José Cláudio Siqueira. Mais grave! Como as tecnologias midiáticas afetam as sensorialidades auditivas $\mathrm{e}$ os códigos sonoros contemporâneos. Contracampo (UFF), v. 23, p. 130-143, 2011c.

PEREIRA, W. A espacialização da fala no cinema. In: Trans/form/ação. São Paulo, 1980; 3: 91-103.

REBOUÇAS, Júlia. A tensão realista de Lucrecia Martel. Eptic: Revista de Economía Política de las Tecnologías de la Información y Comunicación. Dossiê Especial Cultura e Pensamento, Vol. II - Dinâmicas Culturais, dezembro/2006.

SÁ. Simone Pereira de. A trilha sonora de uma história silenciosa: som, música, audibilidades e tecnologias na perspectiva dos Estudos do Som. In: SÁ, Simone Pereira de (org.). Rumos da cultura da música: negócios, estéticas, linguagens e audibilidades. Porto Alegre: Sulina, 2010.

SCHVARZMAN, Sheila. O Rádio e o Cinema no Brasil nos anos 1930. XXIX Congresso Brasileiro de Ciências da Comunicação, Brasília, setembro de 2006. 
SOARES, Luiz Cláudio Cajaiba. Cinema e Dublagem na TV. In: BIÃO, Armindo; PEREIRA, Antonia; SOARES, Luiz Cláudio Cajaiba; PITOMBO, Renata (Org.). Temas em contemporaneidade, imaginário e teatralidade. 1ed. São Paulo: Annablume, 2000, v.1, p145-176.

WAISMAN, David. A conspiração sonora. Filme Cultura, v. 1, n. 4, p. 43, mar./abr. 1967.

VEDANA, Viviane. Diálogos entre a Imagem visual e a imagem sonora : A experiência de escritura do sonoro nos documentários etnográficos. VI Seminário Imagens da Cultura/Cultura das Imagens. Porto, 2010. 